
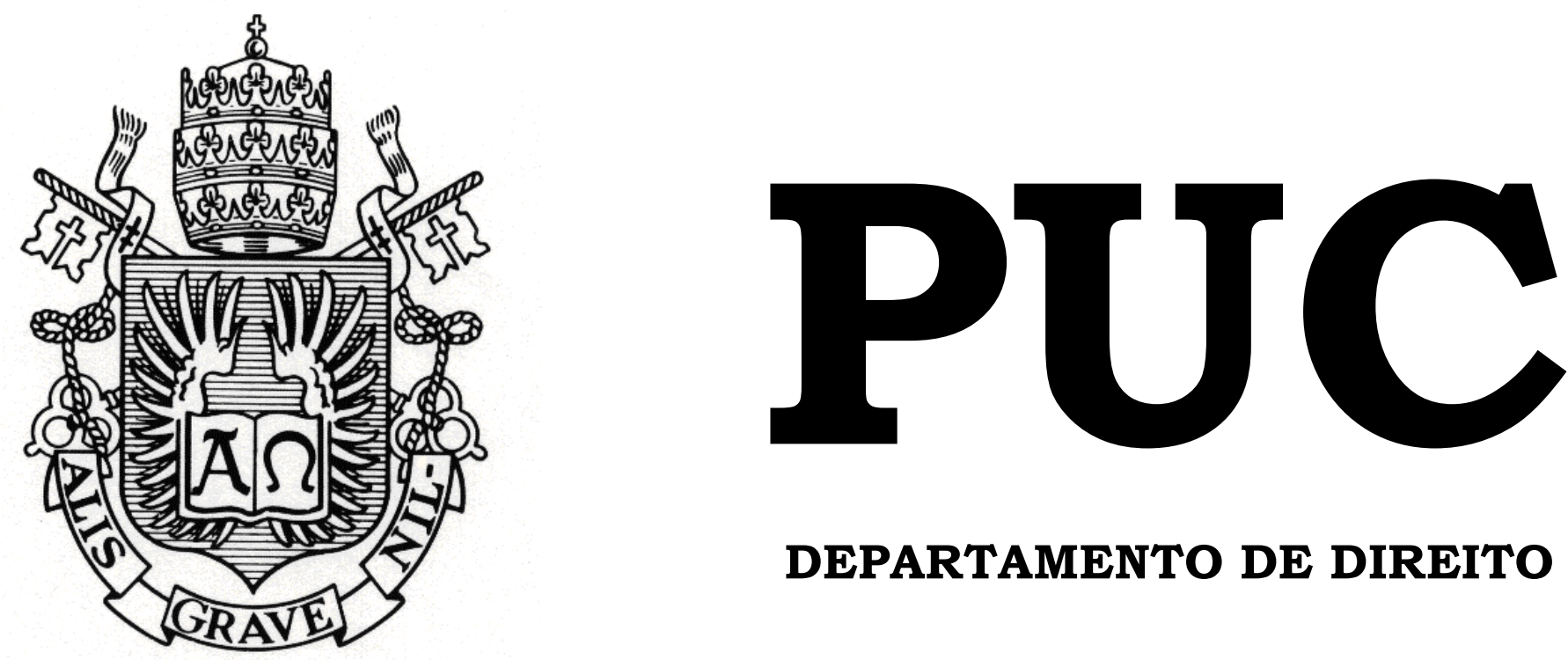

DEPARTAMENTO DE DIREITO

\title{
Insider Trading e o Mercado de Capitais: tratamento legal, casos concretos e a ineficiência econômica de seu combate
}

por

Luiz Felipe Gonçalves Cordeiro

ORIENTADOR: Julian Fonseca Peña Chediak 2013.1

PONTIFÍCIA UNIVERSIDADE CATÓLICA DO RIO DE JANEIRO

RUA MARQUÊS DE SÃO VICENTE, 225 - CEP 22453-900

RIO DE JANEIRO - BRASIL 


\title{
Insider Trading e o Mercado de Capitais: tratamento legal, casos concretos e a ineficiência econômica de seu combate
}

\author{
por \\ Luiz Felipe Gonçalves Cordeiro
}

Monografia

apresentada

ao

Departamento de Direito da Pontificia Universidade Católica do Rio de Janeiro (PUC-Rio) para a obtenção do Título de Bacharel em Direito.

Orientador: Julian Fonseca Peña Chediak 
"You see, as is so often the case, people attribute things to the free market which are really the consequences of government interference with the free market."

(Milton Friedman, em entrevista concedida à rede de televisão americana CNBC, em março de 2003). 


\section{Agradecimentos}

Homenagear e agradecer a todas as pessoas que nestes últimos cinco anos contribuíram para que eu chegasse até aqui seja, talvez, tarefa mais difícil que escrever este trabalho.

Começo por uma pessoa que, infelizmente, não está mais aqui, mas que tenho certeza que, esteja onde estiver, comemora comigo este momento: ao meu padrasto, segundo pai, irmão e amigo, Carlos Paschoal (Thuga), pela educação, ensinamentos, e, principalmente, pelo exemplo de pessoa e de profissional. Minha eterna gratidão.

Aos meus pais, Bianca e Luiz Henrique, todos os agradecimentos do mundo não seriam suficientes. Limito-me, então, a agradecer pela estrutura, apoio, amor e retidão com que sempre conduziram minha criação. De famílias extremamente humildes, ambos cresceram na vida pelo suor do próprio trabalho para que hoje eu possa estar onde estou.

Aos meus irmãos, Vinícius, Letícia e Carolina, por terem me estimulado a, na qualidade de irmão mais velho, dar o meu melhor para que pudessem me ter como um exemplo e referência.

À minha avó, Célia, por toda a doçura, simplicidade e humildade que fazem com que me sinta pequeno perto da sua grandeza como pessoa.

À Jaqueline (Jackie), minha madrasta, tutora e amiga, por ter me acolhido como um filho e ter me incentivado a sempre ir mais longe e a nunca me contentar com o status quo.

À Laryssa, por todo o companheirismo, amor, carinho e paciência. Agradeço por cada segundo ao seu lado e por cada momento que passamos 
juntos. Há sete anos éramos apenas um estudante do ensino médio e uma caloura de engenharia. Hoje, continuamos sendo as mesmas pessoas - apenas com algumas rugas a mais de preocupação -, mas com um amor incondicional que nos mantém unidos.

Não poderia deixar de agradecer também a todas as pessoas que nestes cinco anos contribuíram para minha formação profissional: aos meus amigos do Tozzini Freire e Campos Mello, obrigado por me ensinarem o verdadeiro significado da expressão "trabalho em equipe" e por todos os ensinamentos que até hoje levo comigo.

Agradeço, especialmente, ao meu grande amigo e mentor, Luiz Antonio Lemos, por ter me dado a oportunidade de vivenciar tudo aquilo que a profissão de um advogado envolve, mas principalmente, pelo apoio incondicional durante grande parte da minha trajetória.

À Gabriela Codorniz, agradeço pela amizade e por ter me proporcionado uma experiência única no Colegiado da Comissão de Valores Mobiliários, sempre me incentivando a estudar incessantemente a matéria que hoje faz parte do meu dia a dia profissional.

Aos meus colegas do Chediak Advogados, agradeço pela confiança depositada, pelo rigor técnico e, principalmente, pela grande oportunidade de fazer parte desta equipe. Um agradecimento especial à Carla Saback Dau, Fernanda Mitsuya e Pedro Brigagão, que dividiram comigo muitas madrugadas de trabalho e as tornaram mais agradáveis.

Agradeço a todos os meus amigos e demais pessoas que estiveram presentes durante todo este percurso. A lista é extensa e, por isso, não me arrisco a citar todos. A vocês, meu muito obrigado. 
Por fim, mas não menos importante, agradeço ao meu orientador, professor e duas vezes chefe, Julian Chediak, pela oportunidade de ter sido seu aluno, monitor, estagiário e orientando. Oportunidade para poucos, que hoje me dá a base para continuar buscando o aperfeiçoamento constante e que fará toda a diferença pelo resto de minha carreira. 


\section{Resumo}

Cordeiro, Luiz Felipe Gonçalves. Insider Trading e o Mercado de Capitais: tratamento legal, casos concretos e a ineficiência econômica de seu combate. 225 p. Monografia (Graduação em Direito) - Pontifícia Universidade Católica do Rio de Janeiro: Rio de Janeiro, 2013.

O presente trabalho tem como primeiro objetivo promover uma análise das razões que levam o Estado a intervir no mercado de capitais, visando identificar os motivos que baseiam o regulador na sua decisão de proibir ou permitir determinadas práticas. Além disso, esta monografia analisará as normas de combate à negociação com base em informações privilegiadas, compilando, em um corpo único, as principais discussões doutrinárias sobre o tema. Ademais, buscar-se-á fazer um apanhado das decisões proferidas no âmbito da Comissão de Valores Mobiliários (“CVM") a respeito do insider trading, identificando a posição da autarquia diante da questão. Por fim, serão apresentadas e analisadas as posições das correntes pró e contra a proibição do insider trading, buscando-se identificar aquela que mais se adequa à realidade regulatória brasileira.

Palavras Chave: Direito Societário - Mercado de Capitais - Mercado de Valores Mobiliários - Eficiência - Estabilidade - Credibilidade - Informação - Proteção ao Investidor - Companha Aberta - Insider Trading - Uso indevido de informações privilegiadas - Comissão de Valores Mobiliários. 


\section{Sumário}

INTRODUÇÃO

Colocação da questão e metodologia utilizada................................................ 11

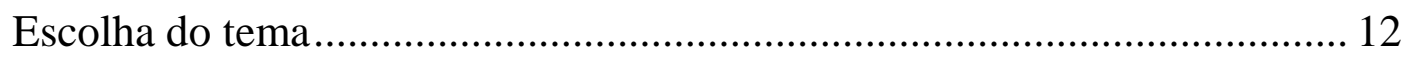

Breve nota sobre o pioneirismo de Henry G. Manne .................................... 13

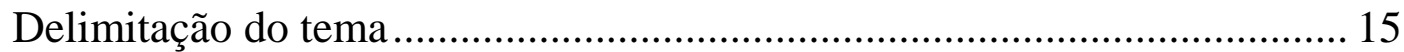

CAPÍTULO 1 - ANTECEDENTES HISTÓRICOS E O CONCEITO DE

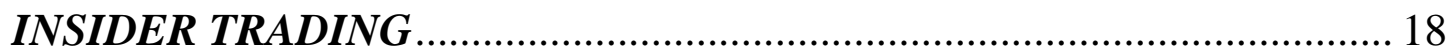

1.1. As primeiras constatações de insider trading nos mercados............ 18

1.2. A separação entre propriedade e gestão …………………………... 20

1.3. Mas afinal, o que significa insider trading? .................................... 22

CAPÍTULO 2 - INTERVENCIONISMO, LIBERALISMO E A ANÁLISE ECONÔMICA DO DIREITO ……….................................... 26

2.1. A intervenção do Estado no domínio econômico ............................... 26

2.2. Conceito de regulação estatal da economia e a decisão de regular. 28

2.3. O pensamento liberal e a Teoria da Captura aplicada à regulação do

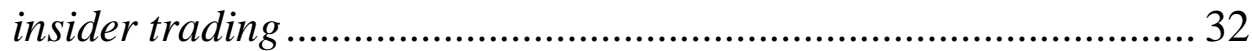

2.4. A escola do law and economics e a busca pela regulação economicamente eficiente.

CAPÍTULO 3 - A REGULAÇÃO DO MERCADO DE CAPITAIS E AS CONDIÇÕES PARA SEU ADEQUADO FUNCIONAMENTO ................ 44

3.1. Conceito de mercado de capitais ..................................................... 44

3.2. Objetivos e princípios da regulação do mercado de capitais

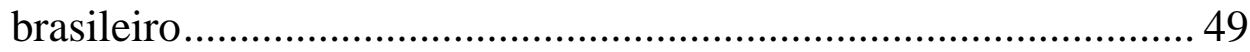

3.3. Assimetria informacional e seleção adversa...................................... 54

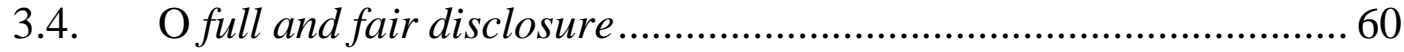

CAPÍTULO 4 - O TRATAMENTO LEGAL DO INSIDER TRADING NO BRASIL

4.1. Evolução legislativa: do Decreto $n^{\circ} 2.627 / 40$ à Lei $n^{\circ} 6.404 / 76$.... 72

4.2. $\quad$ A Lei ${ }^{\circ}$ 6.404/76 e suas alterações.................................................. 75

4.2.1. Comandos de caráter preventivo: Arts. 116-A, 157 e 260............... 75

4.2.2. Comando de caráter repressivo: Art. 155 ........................................ 80

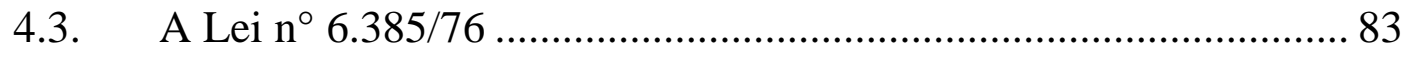




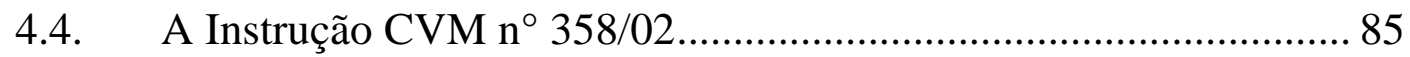

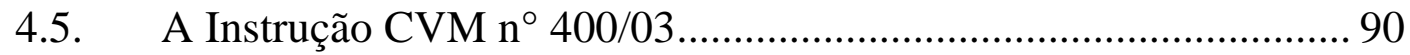

4.6. Consequências do insider trading .................................................. 92

4.6.1. Responsabilidade Civil ................................................................ 92

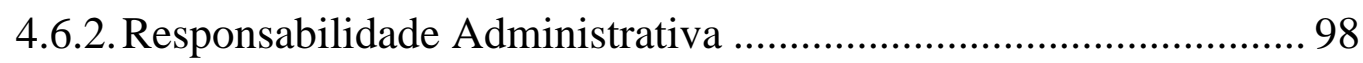

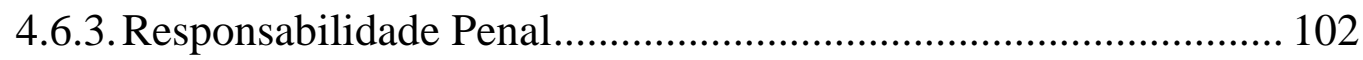

4.6.4. Independência das sanções e o princípio do non bis in idem........ 107

CAPÍTULO 5 - CONSTRUÇõeS DOUTRINÁRIAS E A POSIÇÃO DA

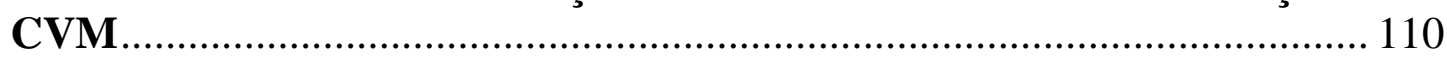

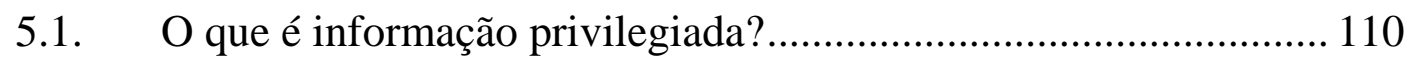

5.1.1. O conceito de "informação privilegiada" proposto por Henry G. Manne.

5.1.2. O entendimento da doutrina brasileira e da CVM

5.2. Insiders primários e secundários e os elementos caracterizadores do insider trading.....

5.3. A utilização de indícios e presunções. 129

5.4. Insider trading em números: um primeiro argumento a favor da legalização...

CAPÍTULO 6 - A INEFICIÊNCIA ECONÔMICA DO COMBATE AO INSIDER TRADING: A PROIBIÇÃO É A MELHOR ALTERNATIVA?

6.1. A corrente majoritária: o insider trading deve ser proibido

6.1.1. Misappropriation theory ............................................................. 142

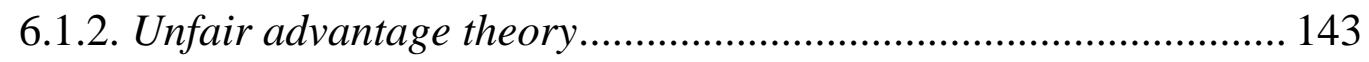

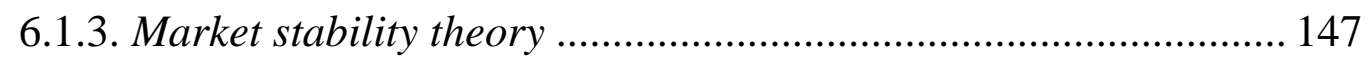

6.1.4. Prejuízos à companhia, aos seus acionistas e aos investidores .... 149

6.1.5. O moral hazard e a produção intencional de notícias negativas.. 151

6.2. A doutrina a favor da legalização do insider trading ........................... 152

6.2.1. Insider trading e sua contribuição para a eficiência do mercado de capitais. 152

6.2.2. O insider trading como um eficiente mecanismo de remuneração dos administradores................................................................. 162

6.2.3. Falhas da unfair advantage theory .............................................. 167

6.2.4. Falhas da market stability theory ................................................. 174 
6.2.5. Falhas do argumento quanto à existência de prejuízos para a companhia, seus acionistas e para os investidores........................ 177

6.2.6. Falhas do argumento quanto ao moral hazard e a produção intencional de notícias negativas................................................ 181

6.2.7. Falhas da misappropriation theory: a premissa básica não se

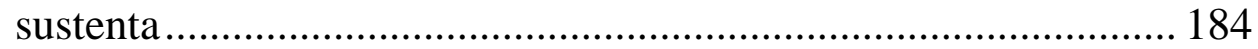

6.2.8. A ineficiência econômica da criminalização do insider trading: uma proposta para a descriminalização ............................................ 188

6.2.9. Uma posição intermediária: a legalização do insider trading no sell

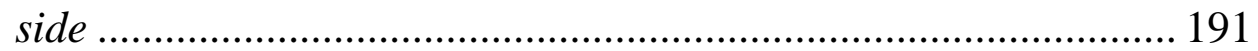

6.2.10. Uma proposta concreta de regulação: a proibição do insider trading a cargo das companhias................................................... 201

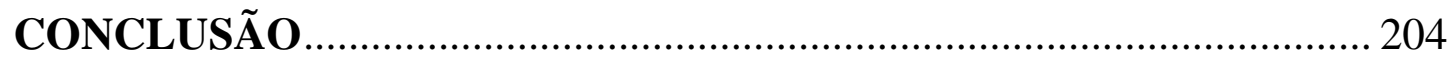

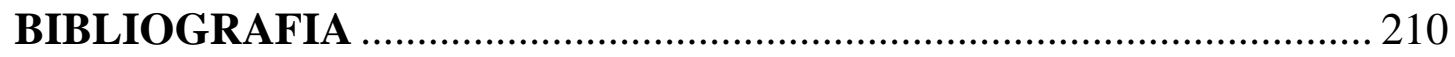




\section{INTRODUÇÃO}

\section{Colocação da questão e metodologia utilizada}

O surgimento do fenômeno empresarial conhecido como "separação entre propriedade e gestão" chamou a atenção da comunidade jurídica e econômica para uma série de questões até então desconhecidas pelo mercado. Neste contexto, diversos autores se dedicaram a estudar as consequências geradas por este fenômeno e, dentre elas, o insider trading.

Na busca por uma maior eficiência do mercado de capitais, reguladores de todo o mundo, inclusive do Brasil, passaram a encarar referida prática como prejudicial ao mercado e aos investidores e, então, buscaram proibi-la de forma cada vez mais intensa.

No entanto, em meados da década de 60 , a doutrina norte-americana do law and economics liderada por Henry G. Manne passou a estudar o insider trading sob um aspecto nunca antes analisado, demonstrando através de diversos argumentos que a negociação com base em informações privilegiadas era benéfica - e não maléfica - aos investidores e, ainda, conferia maior eficiência ao mercado de capitais.

No Brasil, as dificuldades encontradas pela CVM para identificar, processar e condenar aqueles que se utilizam de informações privilegiadas lançam dúvidas sobre a efetividade de tais normas.

Durante as pesquisas para a elaboração do presente trabalho, pôde-se constatar o grande volume de material - nacional e estrangeiro - já escrito sobre o tratamento legal do insider trading e como a questão é tratada pelos órgãos reguladores do mercado de capitais pelo mundo. 
No entanto, especialmente no Brasil, os trabalhos doutrinários já elaborados sobre o tema encontram-se, em sua grande maioria, espalhados por publicações periódicas e artigos específicos, sendo relativamente poucas as obras que efetivamente compilaram as principais questões da matéria em um só corpo.

Além disso, verificou-se que não obstante a importância dos escritos de Henry G. Manne e daqueles que o seguiram na análise do insider trading sob o ponto de vista do law and economics, poucos foram os autores brasileiros que se dedicaram a analisar esta questão com maior profundidade.

É neste contexto, e diante da falta de material nacional discutindo os aspectos jurídicos e econômicos da negociação com base em informações privilegiadas sob o ponto de vista proposto inicialmente por Manne, que se mostra relevante trazer ao arcabouço regulatório brasileiro a discussão sobre a real necessidade de se proibir o insider trading.

\section{Escolha do tema}

A escolha do tema para o presente trabalho teve origem nas aulas de Regulação do Mercado de Capitais ministradas pelo Prof. Julian Chediak, nas quais tive o grande prazer de participar não só como aluno, mas como uma espécie de monitor ad hoc, compilando materiais de leitura e participando das discussões que culminaram com a atualização do conteúdo programático do curso.

Durante este período, pude estudar mais a fundo uma série de questões controversas que antes me pareciam um tanto quanto pacíficas, tais como: a crise norte americana de 2008 foi realmente causada pela falta de regulação? O full and fair disclosure necessariamente confere maior eficiência ao mercado? $\mathrm{E}$, finalmente, o insider trading deve mesmo ser proibido? 
Foi, no entanto, esta última indagação que mais prendeu minha atenção. Mais especificamente, os diversos trabalhos de Henry G. Manne, o primeiro autor a sustentar os efeitos benéficos do insider trading, alertaram-me para o fato de que o que muitos tratam como uma verdade absoluta ${ }^{1}$ merece uma análise mais cuidadosa.

\title{
Breve nota sobre o pioneirismo de Henry G. Manne
}

\author{
Conforme observado por HADDOCK:
}

Henry Manne was not one of the pioneers in the economics of insider trading; he was the pioneer. Before Manne, few scholars even thought the issue worth much serious consideration. A pretty clear path had been beaten through those woods with no heavy lifting required - like any other form of theft, it had casually been concluded, insider trading damaged society by discouraging investment. It seemed that nobody beyond the inside traders themselves could possibly benefit, and even they might well be injured in the larger scheme as the economy as a whole under-performed. ${ }^{2}$

Ainda de acordo com o mencionado autor, no início da década de 60, ao contemplar um fenômeno recorrente já naquela época, Manne se perguntou: "Espere um minuto. A sabedoria popular está mesmo correta?"

Assim como Manne, outros grandes pensadores já desafiaram teses há muito estabelecidas como verdades absolutas. Mas porque os homens fazem isso? Porque os pensamentos de Adam Smith o disseram um dia que a

\footnotetext{
${ }^{1}$ Sobre o tratamento dos efeitos maléficos do insider trading como uma verdade absoluta, confiram-se as constatações de Manne: "Actually, since the early attempts to deal with the subject of corporate insider trading, the matter has generally been assumed to be closed. In 1961, Professor Louis Loss could state that the 'purpose of $\S 16(\mathrm{~b})$ - prevention of the unfair use of information by corporate insiders - does not, of course, admit of dispute'. And a young SEC lawyer, writing in a law review in 1964, stated that 'the policy in favor of providing public investors with all available information that might be material to their investment decisions - a policy too obvious to require further elaboration far outweighs any policy in favor of allowing corporate insiders to trade freely, on the basis of inside information, in the securities of their corporations - a policy for which it is difficult to conceive of any justification." (grifos nossos). MANNE, Henry G., Insider Trading and the Stock Market. New York: Free Press, 1966. p. 11.

${ }^{2}$ HADDOCK, David D. Academic Hostility and SEC Acquiescence: Henry Manne's Insider Trading. 50 Case W. Res. L. Rev. 313 1999-2000. p. 313.
} 
economia não necessitava de um planejamento central ${ }^{3}$ Porque a mente de Ronald Coase o alertou que Pigou focava somente em parte do problema da externalidade? ${ }^{4}$ Finalmente, porque os pensamentos de Henry G. Manne o indicaram que o insider trading poderia melhorar, e não prejudicar, o funcionamento do mercado?

No entanto, parece não haver respostas para estas perguntas. Conforme apontado por HADDOCK:

Great ideas seem almost to come to great thinkers unbidden. I doubt that Smith, Coase, or Manne themselves could point to the precise origin of those ideas (if one could understand such a thing, then everyone could be a Nobel-caliber thinker by merely following a recipe $)^{5}$.

Após uma longa e cuidadosa pesquisa, as ideias de Manne deram frutos com a publicação, em 1966, dos clássicos "Insider Trading and the Stock Market" e "In Defense of Insider Trading".

BAINBRIDGE dá a exata medida do impacto que essas obras causaram no estudo do direito societário nos Estados Unidos:

Henry Manne's 1966 book "Insider Trading and the Stock Market" must be ranked among the truly seminal events in the economic analysis of corporate law. It is only a slight exaggeration to suggest that Manne stunned the corporate law academy by daring to propose the deregulation of insider trading. The traditionalists' response was immediate and vitriolic. In the long run, however, Manne's daring was vindicated in at least one important respect. Although it is hard to believe at this remove, corporate law was regarded as moribund during much of the middle part of this century. Manne's work on insider trading played a major role in ending that long intellectual drought by stimulating interest in economic analysis of corporate law. Whether one agrees with Manne's views on insider trading or not, one must give him

\footnotetext{
${ }^{3}$ SMITH, Adam. An Inquiry Into the Nature and Causes of the Wealth of Nations (R.H. Campbell et a. eds., Oxford Univ. Press 1976). apud. HADDOCK, David D. Academic Hostility and SEC Acquiescence: Henry Manne's Insider Trading. 50 Case W. Res. L. Rev. 313 1999-2000. p. 313.

${ }^{4}$ COASE. R.H. The Problem of Social Cost. 3 J.L \& ECON. 1, 2 (1960). apud. HADDOCK, David D. Academic Hostility and SEC Acquiescence: Henry Manne's Insider Trading. 50 Case W. Res. L. Rev. 313 1999-2000. p. 313.

${ }^{5}$ HADDOCK, David D. Academic Hostility and SEC Acquiescence: Henry Manne's Insider Trading. 50 Case W. Res. L. Rev. 313 1999-2000. p. 313.
} 
due credit for helping to stimulate the outpouring of important law and economics scholarship in corporate law and securities regulation during the 1980s and 1990s. ${ }^{6}$

Atualmente, ainda existem diversos acadêmicos - principalmente norte americanos - que criticam duramente os trabalhos de Manne. No entanto, como bem observado por HADDOCK, "no serious scholar who reflects on insider trading dares ignore Manne - the easy path has been forever closed" ${ }^{7}$.

\section{Delimitação do tema}

Não obstante a temática a ser aqui abordada estar presente na pauta de discussão dos principais países do mundo com mercados de capitais desenvolvidos, este trabalho não se dedicará a promover uma análise comparada da legislação e jurisprudência brasileiras com aquelas existentes em outras jurisdições.

De todo modo, quando necessário para melhor compreensão das questões, serão feitas referências a leis e precedentes de outros países, principalmente dos Estados Unidos, local onde as primeiras normas de combate ao insider trading nasceram e foram testadas perante os tribunais. Quando tais referências forem feitas, seu contexto será brevemente explicado.

Este trabalho não abordará outros ilícitos tipificados na legislação societária e na regulação do mercado de capitais que, em alguns casos, se assemelham ao insider trading, tais como as práticas não equitativas (notadamente o chamado front running) e a manipulação de preços.

O Capítulo 1 apresenta os fatos históricos que antecederam a prática do insider trading e as razões por traz de seu surgimento, notadamente a discussão sobre a separação entre a propriedade e gestão. Neste capítulo buscar-se-á

\footnotetext{
${ }^{6}$ BAINBRIDGE, Stephen M. Insider Trading: An Overview. p. 5. Disponível em http://ssrn.com/abstract=132529.

${ }^{7}$ Ibid. p. 314.
} 
demonstrar como a segregação entre poder decisório e capital dentro das companhias culminou com o surgimento de diversos problemas na empresa moderna. Também neste capítulo será oferecido um conceito preliminar de insider trading, posteriormente elaborado nos capítulos seguintes.

O Capítulo 2 será dedicado a analisar as razões que levam o Estado a intervir na Economia, visando identificar a origem por trás das normas que impõem obrigações e proíbem determinadas práticas nos diversos mercados. Além disso, este capítulo será dedicado a estudar as correntes que criticam a regulação estatal excessiva, traçando-se um paralelo entre elas e a regulação do insider trading.

O Capítulo 3 trará os principais conceitos relacionados à regulação do mercado de capitais, buscando-se identificar os objetivos e princípios que regem esta regulação de acordo com a legislação brasileira. Neste capítulo também serão estudados em maior profundidade duas questões intimamente relacionadas à regulação do mercado de capitais, quais sejam o problema da assimetria informacional e o princípio do full and fair disclosure, identificando-se como tais questões guardam relação direta com a prática do insider trading.

No Capítulo 4 serão analisados todos os dispositivos legais atualmente em vigor que regulam e proíbem a negociação com base em informações privilegiadas, com o intuito de prover o leitor com um guia legislativo sobre o tema.

O Capítulo 5 será dedicado a analisar as principais discussões doutrinárias e interpretações da $\mathrm{CVM}^{8}$ sobre o insider trading, buscando

\footnotetext{
${ }^{8}$ A opção por concentrar a pesquisa nas decisões da CVM se deve ao fato de que a maior parte dos casos de insider trading é analisada no âmbito do poder fiscalizador da autarquia. Além disso, até a presente data, são pouquíssimas as decisões judiciais envolvendo o uso de informações privilegiadas, estando muitos dos casos sob segredo de justiça. Ademais, optou-se por não trazer no presente trabalho
} 
identificar os entendimentos dominantes sobre as diversas questões que surgem durante a aplicação das normas que proíbem referida prática.

Finalmente, no Capítulo 6, com base no arcabouço regulatório brasileiro e na aplicação prática das normas de combate ao uso de informações privilegiadas, serão apresentados e analisados os principais argumentos dos autores que defendem a proibição do insider trading e daqueles que entendem que a prática deveria ser legalizada.

o posicionamento do Conselho de Recursos do Sistema Financeiro Nacional, pois, em regra, referido órgão costuma ratificar as decisões da CVM nos casos de insider trading, não havendo, portanto, inovações relevantes que merecessem maior destaque. 


\section{CAPÍTULO 1 - ANTECEDENTES HISTÓRICOS E O CONCEITO DE INSIDER TRADING}

Em um dos primeiros artigos sobre a negociação com base em informações privilegiadas, publicado três anos após a promulgação da Lei ${ }^{\circ}$ 6.404/76, MUSSNICH já advertia:

[...] para que se possa entender o que significa a expressão "insider trading" [...] é preciso, inicialmente, acompanhar o desenvolvimento da estrutura organizacional das empresas modernas através dos tempos, pois "insider trading" é uma das últimas consequências dos problemas trazidos com a sua rápida evolução?

Dessa forma, antes mesmo que seja abordado o conceito jurídico de “insider trading”, faz-se necessário analisar, ainda que brevemente, a evolução da empresa moderna, buscando-se identificar como o seu desenvolvimento ao longo do tempo contribuiu para o surgimento de um mercado de capitais cada vez mais complexo e dinâmico, suscetível, portanto, ao surgimento - ou, ao menos, ao crescimento - de fenômenos como o insider trading.

\subsection{As primeiras constatações de insider trading nos mercados}

As primeiras discussões acadêmicas sobre o insider trading datam do começo do século XX, quando H.L. WILGUS ${ }^{10}$ publicou, em 1910, o primeiro artigo sobre o tema.

Não obstante, a existência de práticas abusivas no mercado já se mostravam presentes quando da criação das primeiras sociedades por ações em 1609. De acordo com LAMY, “já em 1609 (apenas sete anos após a fundação

\footnotetext{
9 MUSSNICH, Francisco Antunes Maciel. A utilização desleal de informações privilegiadas "insider trading" - no Brasil e nos Estados Unidos. Revista de Direito Mercantil, Industrial, Econômico e Financeiro. São Paulo: n 34, ano XVIII, abr.-jun. 1979. p. 31.

${ }^{10}$ WILGUS, H.L. Purchase of Shares of Corporation by a Director from a Shareholder (1910) 8 Mich. L. Rev. 267. apud GILLEN, Mark. The Role of Securities Regulation in Promoting a Competitive Capital Market (May 25, 2006), disponível em http://www.tfmsl.ca
} 
da Companhia) havia clamor público contra abusos nas manipulações da Bolsa, o que deu causa à sua coibição mediante decretos de 1610"11.

No entanto, COSTA e RAMOS afirmam que em que pese já existirem desde a Idade Média protestos contra os benefícios obtidos por grupos limitados de pessoas que negociavam títulos com base em informações privilegiadas, é "no século XX que de modo reiterado se expõe e se denuncia a prática que é internacionalmente conhecida como insider trading ou insider dealing $" 12$.

Por outro lado, MANNE, um dos primeiros autores a defender abertamente os efeitos benéficos do insider trading para o mercado, ressalta, ao abordar o tema no âmbito do mercado de capitais norte americano:

Prior to the year 1910 no one had ever publicly questioned the morality of corporate officers, directors, and employees trading in the shares of corporations. There are several reasons why attitudes began to change early in the twentieth century. Part of the reason was simply a time lag between the dramatic, almost revolutionary development of the large publicly held corporation in the last quarter of the nineteenth century and the recognition of all the problems created by this institution.

E assevera:

The functional relationship of shareholders in the corporation to each other had changed dramatically. No longer was it possible for each shareholder to demand in a personal and imperative way that his business associates deal with him fairly ${ }^{13}$.

De fato, conforme se verá a seguir, a discussão sobre o insider trading tomou novos rumos a partir do início do século XX, notadamente após o surgimento do fenômeno conhecido como separação entre propriedade

\footnotetext{
${ }^{11}$ LAMY FILHO, Alfredo e BULHÕES PEDREIRA, José Luiz. A Lei das S.A. Rio de Janeiro: Ed. Renovar, 1997, Vol. I, p. 87.

${ }^{12}$ COSTA, José de Faria; RAMOS, Maria Elisabete. $O$ crime de abuso de informação privilegiada. Coimbra: Coimbra Editora, 2006. p. 18.

${ }^{13}$ MANNE, Henry G., Insider Trading and the Stock Market. New York: Free Press, 1966. p. 1.
} 
acionária e gestão, discutido no pioneiro trabalho "The Modern Corporation and Private Property", de Adolf A. Berle e Gardiner C. Means ${ }^{14}$.

\subsection{A separação entre propriedade e gestão}

COMPARATO, em sua clássica obra sobre o poder de controle na sociedade anônima, anota:

[...] um dos fenômenos básicos da sociedade anônima moderna, já anunciado ante litteram por Karl Marx e largamente demonstrado, pela primeira vez, na célebre pesquisa de Berle e Means nos Estados Unidos, com base em dados estatísticos de 1929, é a possibilidade de dissociação entre propriedade acionária e poder de comando empresarial $[\ldots]^{15}$.

O fenômeno da separação entre a propriedade acionária e o comando da empresa foi de tal forma relevante para os estudos que se seguiram sobre as sociedades anônimas ${ }^{16}$, que passou-se a delinear dois grandes períodos na vida das empresas modernas.

Em um primeiro período, o fundador da empresa era, em regra, o acionista controlador, possuindo, portanto, o poder de determinar os rumos da

\footnotetext{
${ }^{14}$ Luiz Gastão Paes de Barros Leães destaca que a segregação entre propriedade e gestão foi crucial para o desenvolvimento da prática conhecida como insider trading, a qual, segundo o autor é "um dos mais graves exemplos das disfunções do mecanismo societário nas companhias de mercado, decorrente da cisão entre a propriedade e o controle dos bens de produção, ocorrida na economia moderna, já assinalados por Berle e Means em 1927 no seu livro clássico The Modern Corporation and Private Property [...]".LEÃES, Luiz Gastão Paes de Barros. Mercado de Capitais \& "Insider Trading". 1ª ed. São Paulo: Ed. Revista dos Tribunais, 1978. p. 149.

${ }^{15}$ COMPARATO, Fábio Konder. O poder de controle na sociedade anônima. $2^{\mathrm{a}}$ ed. atualizada. São Paulo: Ed. Revista dos Tribunais, 1977. p. 33/34.

${ }^{16}$ Nas palavras de Nelson Eizirik, "a discussão referente à separação entre propriedade e controle na macroempresa apresenta grande importância para o entendimento mais completo das transformações que a Companhia Aberta pode acarretar na instância jurídica. Conforme vários autores, as empresas efetivamente 'abertas' em sua estrutura de capital e propriedade operariam modificações de relevo nas sociedades capitalistas avançadas. Assim, os aspectos positivos de tal 'abertura' ou 'democratização' do capital das grandes empresas, particularmente daquelas que recorrem ao mercado de capitais para o financiamento de seus projetos de expansão, são referidos principalmente a determinadas alterações na estrutura da propriedade privada, em sua feição clássica. Tais alterações trariam, conforme esta linha de pensamento, consequências relevantes a nível econômico e jurídico". EIZIRIK, Nelson Laks. Questões de Direito Societário e Mercado de Capitais. Rio de Janeiro: Forense. $1^{\mathrm{a}}$ ed. 1987. p. 3.
} 
companhia. Nesta fase, empresa e empresário se confundiam, "assim como confundiam-se as noções de administração e capital" ${ }^{17}$.

Posteriormente, já em um segundo período, as empresas passam a conhecer um novo ator dentro de sua estrutura organizacional, qual seja, o administrador profissional. Esta figura aparece, principalmente, como uma resposta à necessidade de profissionalização da gestão dos negócios sociais, necessidade esta trazida especialmente após a Segunda Guerra Mundial ${ }^{18}$, com o surgimento de uma nova ordem econômica e social.

A complexidade que assumem as unidades de produção, a evolução dos mercados de capitais internacionais e a modernização das economias de mercado, dentre outros fatores, passam a exigir que as empresas adotem mecanismos de gestão cada vez mais diferenciados e técnicos, visando acompanhar esta crescente evolução ${ }^{19}$.

Desta forma, o fundador da empresa, que antes era capaz de gerir o seu negócio sem a necessidade de grandes conhecimentos técnicos ou de um terceiro dotado da devida especialização para tal, passa, agora, a depender de administradores cada vez mais qualificados e capacitados.

Surge, assim, um novo foco de controle nas companhias, não mais atrelado à propriedade das ações, mas oriundo do conhecimento técnico detido por determinados profissionais que assumem a gestão ativa da empresa.

\footnotetext{
17 MUSSNICH, Francisco Antunes Maciel. A utilização desleal de informações privilegiadas "insider trading" - no Brasil e nos Estados Unidos. Revista de Direito Mercantil, Industrial, Econômico e Financeiro. São Paulo: n 34, ano XVIII, abr.-jun. 1979, p. 32.

${ }^{18}$ De acordo com Maria Isabel de Almeida Alvarenga, "após o final da Segunda Guerra Mundial, o desenvolvimento econômico tornou-se preocupação constante de governos, elites e organismos internacionais". ALVARENGA, Maria Isabela de Almeida. Adequação das funções legais da Comissão de Valores Mobiliários a realidade brasileira. Revista de Direito Mercantil, Industrial, Econômico e Financeiro. São Paulo: n 105, ano XXXVI, jan.-mar. 1997. p. 31.

19 NASCIMENTO, João Pedro Barroso do. Medidas Defensivas à Tomada de Controle de Companhias. São Paulo: Quartier Latin, 2011. p. 21.
} 
Assim, ressaltando a importância do fenômeno da separação entre a propriedade acionária e a gestão da empresa para a intensificação da prática do insider trading, MUSSNICH afirma:

Esta separação de poder, aliada à continuada necessidade de atrair, cada vez mais, maiores somas de capital dos investidores, alertou a comunidade jurídica e econômica para um novo e difícil problema - a utilização desleal de informações privilegiadas por parte dos administradores, gerando a necessidade da criação de novos institutos jurídicos, para a proteção dos investidores, credores e terceiros.

E prossegue:

Ficara evidente que a proximidade e conhecimento dos administradores, dos fatores e métodos de produção, possibilitava a extração de informações privilegiadas, o que assim os colocava em uma situação de superioridade, em comparação com as outras pessoas que não possuíam o mesmo fácil acesso ${ }^{20}$.

\subsection{Mas afinal, o que significa insider trading?}

Conforme mencionado na introdução deste trabalho, os Capítulos 4 e 5 serão dedicados a estudar com maior minúcia o tratamento legal e doutrinário dos principais aspectos relacionados ao insider trading.

No entanto, tendo em vista que antes de chegar a tais capítulos, o termo "insider trading" será mencionado em diversas passagens, cumpre-me oferecer, ainda que preliminarmente, uma explicação sobre o que significa tal expressão.

Utilizando-se da já clássica definição oferecida por EIZIRIK ${ }^{21}$, pode-se dizer que o insider trading

[...] consiste na utilização de informações relevantes sobre valores mobiliários, por parte de pessoas que, por força de sua atividade profissional, estão "por dentro" dos

${ }^{20}$ MUSSNICH, Francisco Antunes Maciel. MUSSNICH, Francisco Antunes Maciel. A utilização desleal de informações privilegiadas - "insider trading" - no Brasil e nos Estados Unidos. Revista de Direito Mercantil, Industrial, Econômico e Financeiro. São Paulo: n 34, ano XVIII, abr.-jun. 1979, p. 32.

${ }^{21}$ EIZIRIK, Nelson Laks; GAAL, Ariádna B.; PARENTE, Flávia; HENRIQUES, Marcus de Freitas. Mercado de Capitais - regime jurídico. 2. ed. (revisada e atualizada). Rio de Janeiro: Renovar, 2008. p. 536. 
negócios da emissora, para transacionar com os valores mobiliários antes que tais informações sejam de conhecimento público.

Em sentido semelhante, SCALZILLI e SPINELLI definem o "insider trading" como

[...] a utilização de informação relevante capaz de afetar a negociação de valores mobiliários antes de ser ela divulgada aos demais investidores, por pessoa que a tenha obtido, normalmente, por força de relação profissional mantida com a companhia. $^{22}$

CARVALHOSA, por sua vez, define o "insider trading" como

[...] qualquer operação realizada por um insider, com valores mobiliários de emissão da companhia, no período imediatamente seguinte ao conhecimento da informação relevante e antes que tal informação chegue ao público investidor pelos meios institucionais de divulgação adotados no mercado de capitais. ${ }^{23}$

Transpassado o campo teórico, veja-se um exemplo prático de insider trading oferecido por EIZIRIK:

Por exemplo, e para tornar clara a figura do insider trading, mesmo correndo o risco da caricatura: o diretor da Companhia Aberta X, a qual dedica-se à prospecção de minério, sabendo que ela realizaria uma grande descoberta, passa a comprar no mercado as ações de sua emissão, sem notificar tal descoberta ao público. Após a divulgação pública da descoberta, que tem como consequência uma elevação na cotação em Bolsa das ações, o diretor passa a vender os títulos que havia comprado, ainda antes da 'alta'. Os lucros havidos, no caso, são evidentemente decorrentes da posse e utilização, em proveito próprio, de informação confidencial da empresa, a qual o insider havia tido acesso apenas pela posição que nela ocupava. ${ }^{24}$

Como visto acima, os doutrinadores oferecem definições muito semelhantes do que seja "insider trading". Esta expressão é comumente designada no Brasil como "negociação com base em informações privilegiadas" ou "uso indevido de informações privilegiadas". Deve-se

\footnotetext{
${ }^{22}$ SCALZILLI, João Pedro; SPINELLI, Luis Felipe. A Racionalidade Econômica do Combate ao Insider Trading: Assimetria de Informação e Dano ao Mercado. Revista de Direito Mercantil, Industrial, Econômico e Financeiro. São Paulo: n 147, ano XLVI, jul.-set. 2007. p. 43.

${ }^{23}$ CARVALHOSA, Modesto. Comentários à Lei das Sociedades Anônimas. 4. ed. São Paulo. Saraiva, 2009. vol. 3, p. 311.

${ }^{24}$ EIZIRIK, Nelson Laks. Insider Trading e a Responsabilidade de Administrador de Companhia Aberta. Revista de Direito Mercantil, Industrial, Econômico e Financeiro. São Paulo: $n^{\circ}$ 50, ano XXII, abr.-jun. 1983. p. 43.
} 
ressalvar, no entanto, que a utilização desta segunda expressão para designar o insider trading deve ser cercada de cuidados, pois nem todas as operações realizadas por insiders caracterizam o uso indevido de informações privilegiadas. Assim é, por exemplo, o caso do administrador de uma companhia aberta - um insider, portanto, em relação a ela - que negocia ações de sua emissão no mercado de acordo com a política de negociação estabelecida pela referida companhia. Neste caso, mesmo estando por dentro dos assuntos da companhia que administra, as negociações feitas pelo administrador não são indevidas ou ilícitas ${ }^{25}$.

Feitas estas considerações, e antes de adentrar nas especificidades do insider trading e nas discussões que o cercam, deve-se dar um passo atrás para buscar compreender as razões pelas quais o Estado decidiu intervir na economia, e mais especificamente, no mercado de capitais, proibindo a negociação com base em informações privilegiadas.

Neste ponto, discorrendo sobre a importância das normas jurídicas e os efeitos que as mesmas produzem na economia, EIZIRIK ensina:

[...] é inegável que as normas jurídicas influenciam muitas vezes a economia, modificando-a de tal forma que podem mesmo ser consideradas como causas de determinados resultados econômicos. Isto porque as normas são em geral elaboradas com vistas a produzir determinados resultados econômicos. Acrescentaríamos, aqui, que a própria noção de eficácia da norma jurídica, tal como definida por Capella, dirige a atenção do observador para os objetivos contidos na norma, para os fins desejados pelo legislador; uma norma será eficaz, então, na medida em que seus objetivos (via de regra produzir determinados resultados econômicos) sejam realmente alcançados ${ }^{26}$.

\footnotetext{
${ }^{25}$ A própria SEC reconhece que em determinados casos o insider trading é lícito, não sendo, portanto, correto traduzi-lo de forma genérica para a expressão em português "uso indevido de informações privilegiadas": "“Insider trading' is a term that most investors have heard and usually associate with illegal conduct. But the term actually includes both legal and illegal conduct. The legal version is when corporate insiders - officers, directors, and employees - buy and sell stock in their own companies. When corporate insiders trade in their own securities, they must report their trades to the SEC." Disponível em http://www.sec.gov/answers/insider.htm.

${ }^{26}$ EIZIRIK, Nelson Laks. O Liberalismo Econômico e a Criação das Disciplinas de Direito Comercial e Economia Política. Revista de Direito Mercantil, Industrial, Econômico e Financeiro. São Paulo: ${ }^{\circ}$ 35, ano XVIII, jul.-set. 1979. p. 30
} 
Desta forma, mostra-se relevante verificar como se dá a atuação do Estado no desempenho do seu papel de regulador último da economia, visando identificar as razões por trás das normas de combate ao insider trading, cerne deste trabalho. 


\section{CAPÍTULO 2 - INTERVENCIONISMO, LIBERALISMO E A ANÁLISE ECONÔMICA DO DIREITO}

\subsection{A intervenção do Estado no domínio econômico}

O estudo sobre a origem da regulação estatal da economia tem como ponto de partida o momento de transição da ordem econômica baseada em um modelo liberal para o modelo intervencionista, por força do qual o Estado passa a interferir de forma mais intensa nas relações econômicas.

Neste contexto, explica PROENÇA:

Muito embora o progresso e o desenvolvimento da tecnologia e da atividade econômica, em si, tivessem sido notáveis, os aproximadamente 150 anos de vivência do sistema liberal produziram um quadro política e socialmente conturbado, acabando por trazer à mostra importantes falhas, inoperacionalidades ou imperfeições, devidas ao alto grau de dificuldade anteposto à função de coordenar a teia dos inúmeros aspectos da economia.

$[\ldots]$

O direito positivo ocorreu, então, para eliminar, ou, pelo menos, mitigar, similares estorvos à operacionalidade do mercado. $\mathrm{O}$ Estado reingressa, nesse instante, no panorama econômico, mediante a edição de normas de caráter geral e regulamentar.

$[\ldots]$

Iniciou-se, assim, o fenômeno da intervenção do Estado na economia, ou no domínio econômico, e a sua aceitação, cercada, embora, de cautelas para limitar a ação estatal ao estritamente necessário, a fim de suprir as disfunções maiores do sistema sem, contudo, tolher-lhe, integralmente, a autonomia de funcionamento ${ }^{27}$.

A grande depressão de 1929 representou um dos principais marcos nesta trajetória, sendo considerada a mais grave crise do sistema capitalista até então. É neste contexto que surge o novo marco regulatório americano, implementado pelo New Deal de Franklin Delano Roosevelt ${ }^{28}$, a partir do qual o Estado, de

\footnotetext{
27 PROENÇA, José Marcelo Martins. Insider Trading. Regime jurídico do uso de informações privilegiadas no mercado de capitais. São Paulo: Ed. Quartier Latin, 2005. p. 151.

${ }^{28}$ Nesse contexto, é particularmente relevante a legislação reguladora do mercado de capitais norte americano, também dessa época. Refiro-me ao Securities Act, de 1933, e ao Securities and Exchange Act, de 1934. Conforme observado na Introdução deste trabalho, não se fará aqui uma abordagem
} 
uma maneira geral, passa a assumir uma postura mais ativa diante dos participantes do mercado, transformando-se em órgão regulador e motor da economia.

Conforme observado por LEÃES, “através do planejamento econômico, da política econômica, e das atividades empresariais diretas, o Estado, em sua função reguladora, substitui em parte o mercado, definindo preços, salários, e taxas de juros, estabelecendo prioridades para o investimento privado e orientando o consumo através de taxas diferenciadas" ${ }^{29}$.

Esta intervenção estatal na economia pode se dar de diferentes formas. De acordo com os ensinamentos de $\mathrm{GRAU}^{30}$, compartilhando do entendimento adotado por BANDEIRA DE MELLO ${ }^{31}$, o Estado pode regular a economia por indução (criando incentivos a determinadas atividades econômicas, por meio, por exemplo, da seletividade no estabelecimento de alíquotas de impostos), por direção (estabelecendo normas cogentes), ou por intervenção, que por sua vez se subdivide em intervenção por absorção (quando o Estado assume integralmente os meios de produção, em regime de monopólio) e intervenção por participação (quando o Estado controla parte dos meios de produção, em regime de competição com empresas privadas) $)^{32}$.

exaustiva da legislação norte americana, a qual será citada pontualmente, sempre que o contexto o exigir.

${ }^{29}$ LEÃES, Luiz Gastão Paes de Barros. Mercado de Capitais \& “Insider Trading”. 1ª ed. São Paulo: Ed. Revista dos Tribunais, 1978. p. 24.

${ }^{30}$ GRAU, Eros. A ordem econômica na constituição de 1988. 3. ed. São Paulo: Malheiros, 1997. p. 65

${ }^{31}$ MELLO, Celso Antônio Bandeira. O Estado e a Ordem Econômica. Revista de Direito Público RDP 62/34 abr.-jun./1982. p. 1.

${ }^{32}$ Natalino Irti também traz uma interessante classificação das normas reguladoras da economia, a saber, normas proibitivas, atributivas e conformadoras. As normas proibitivas seriam aquelas que restringem a atuação dos agentes econômicos e o acesso a certos bens, determinando, desta forma, o que deve ser mantido fora de um determinado mercado. As normas atributivas, por sua vez, seriam as normas que conferem posições legitimadoras aos sujeitos ou aos bens por eles negociados. Finalmente, as normas conformadoras seriam aquelas que, regulando as operações permitidas, moldam a conduta dos agentes do mercado. IRTI, Natalino. L'Ordine Giuridico del Mercato. Bari: Editori Laterza, 2003. p. 44. 
Para os objetivos do presente trabalho, nos interessa mais a regulação por direção ${ }^{33}$, uma vez que é por meio de normas preventivas e repressivas que o Estado visa regular o mercado de capitais e, mais especificamente, coibir a prática conhecida como insider trading.

Verificada, ainda que de forma breve, a origem da intervenção do estado no domínio econômico e as formas que tal intervenção pode tomar, deve-se buscar compreender o conceito por trás da regulação estatal da economia para, em seguida, investigar as razões que estão por trás da - muitas vezes perigosa - decisão de regular.

\subsection{Conceito de regulação estatal da economia e a decisão de regular}

O conceito de regulação estatal da economia tem se mostrado cada vez mais relevante, seja por adquirir contornos constitucionais (vide arts. 21, XI; 174; e 177, §2 , III da Constituição Federal), seja pelo fato de ser usado para qualificar as entidades da administração pública conhecidas como agências reguladoras, encarregadas de disciplinar determinados setores da economia.

Nas lições de SZTAJN,

[...] regular significa formular e impor regras em forma de intervenção do Estado no domínio econômico. Essa matéria, regulação, interessa a diferentes áreas do conhecimento, particularmente ao direito e à economia. Regulação pode ser entendida como o conjunto de regras predispostas por um órgão ou agência da administração indireta, visando a fiscalizar e garantir, pela observância ou cumprimento, a disciplina de certas atividades ou setores da atividade econômica.

\footnotetext{
${ }^{33}$ Nesse sentido, Otávio Yazbek afirma que "[...] com efeito, ao se tratar de regulação das atividades bancárias, securitárias e de mercado de capitais, se está tratando de campos tipicamente explorados por agentes privados e que, desde sempre, foram objeto de regulamentação e de controle pelo Estado. Trata-se de campos em que, conforme classificação adotada por Grau, se desenvolve 'atividade econômica em sentido estrito', em que o Estado não tende a atuar diretamente, mas sobre a qual ele pode intervir. Tal intervenção se dá, predominantemente, por 'direção', ou seja, pelo estabelecimento de 'mecanismos e normas de comportamento compulsório' para os agentes que ali operam. Ao lado dessa intervenção por direção, o Estado também pode intervir por 'indução', criando estímulos aos agentes e procurando, assim, direcionar as atividades destes a partir de mecanismos premiais". YAZBEK, Otávio. Regulação do mercado financeiro e de capitais. Rio de Janeiro: Elsevier, 2009. p. 180
} 
Pode-se denominar regulação ao conjunto de normas visando determinado efeito ou, em sentido muito amplo, o conjunto de mecanismos de controle social ${ }^{34}$.

Aproximando o conceito da regulação estatal da economia à realidade brasileira $^{35}$, ARAGÃO define referida regulação como:

[...] o conjunto de medidas legislativas, administrativas e convencionais, abstratas ou concretas, pelas quais o Estado, de maneira restritiva da liberdade privada ou meramente indutiva, determina, controla ou influencia o comportamento dos agentes econômicos, evitando que lesem os interesses sociais definidos no marco da Constituição e orientando-os em direções socialmente desejáveis ${ }^{36}$.

Mas quais seriam as motivações dos legisladores para decidirem as “direções socialmente desejáveis"? Tomariam eles suas decisões baseados em dados estritamente técnicos? Seriam eles capazes de antever todos os efeitos que uma determinada norma poderia gerar na economia do país? É justamente neste ponto que nos cabe analisar uma última constatação, qual seja, a de que a decisão de regular ou não regular é essencialmente política.

Neste sentido, confiram-se as lições de YAZBEK:

Claro que, os fundamentos técnico-econômicos da regulação convivem sempre com decisões políticas. Não apenas porque, em última instância, a opção pela intervenção em atividades privadas funda-se em opções ideológicas ou conjunturais [...], mas também porque o desenvolvimento dos sistemas financeiros nacionais não raro é impulsionado pela implementação de políticas públicas ${ }^{37}$.

\section{No mesmo sentido conclui EIZIRIK:}

\footnotetext{
${ }^{34}$ SZTAJN, Rachel. Regulação e o Mercado de Valores Mobiliários. Revista de Direito Mercantil, Industrial, Econômico e Financeiro. São Paulo: n ${ }^{135}$, ano XLIII, jul.-set. 2004. p. 137.

35 Nelson Eizirik também traz um conceito de regulação similar aos demais, sustentando que a regulação pode ser entendida como "a atuação predominantemente estatal (embora não necessariamente exercida pelo Estado, como no caso da auto-regulação, realizada pelos próprios membros de determinada indústria), no sentido de editar normas e fiscalizar seu cumprimento, no contexto de um mercado determinado, limitando a liberdade de atuação de seus participantes". EIZIRIK, Nelson Laks. O papel do Estado na Regulação do Mercado de Capitais. Rio de Janeiro, Instituto. Brasileiro de Mercado de Capitais - IBMEC, 1977. p. 31.

${ }^{36}$ ARAGÃO, Alexandre Santos de. O conceito jurídico de regulação da economia. Revista de Direito Mercantil, Industrial, Econômico e Financeiro. São Paulo: n 122, ano XL, abr.-jun. 2001. p. 47.

${ }^{37}$ YAZBEK, Otávio. Regulação do mercado financeiro e de capitais. Rio de Janeiro: Elsevier, 2009. p. $187 / 188$.
} 
Devemos notar, antes de mais nada, que as legislações por meio das quais se estabelecem os modelos regulatórios são elaboradas tendo em vista os interesses da política econômica em um Estado determinado, em um dado momento. Daí então suas características próprias, variando assim as formas como os Estados regulam os mercados; considere-se ainda que, dentro de um mesmo país, diferentes mercados exigirão diferentes regulações ${ }^{38 / 39}$.

Tal constatação mostra-se importante, uma vez que, ao se analisar o sentido econômico de uma norma jurídica (como as normas de combate ao insider trading), é preciso ter em mente que a decisão de regular ou não regular determinada atividade é tomada por seres humanos, que nem sempre basearão suas decisões em conclusões puramente técnicas, mas muitas vezes atuarão sob a pressão de certos setores políticos e sociais da comunidade em que se inserem. Mas não é só isso.

Tendo em vista que os legisladores nada mais são que seres humanos eleitos pelo povo para editar regras, suas decisões, por mais bem intencionadas que sejam, dificilmente serão capazes de prever todos os efeitos que uma determinada norma poderá gerar, seja no campo econômico, seja no campo social. Logo, ainda que a decisão de regular esteja completamente isenta de pressões políticas e ideológicas, a impossibilidade de enxergar todos os cenários possíveis sujeita os legisladores a erros de julgamento, que em alguns casos podem trazer efeitos nefastos para a economia.

Neste contexto, CONSTANTINO observa:

[...] não são poucas as pessoas que, mesmo com algum conhecimento de economia, defendem inúmeras medidas intervencionistas por parte do governo. Alegam que o

\footnotetext{
${ }^{38}$ EIZIRIK, Nelson Laks. O papel do Estado na Regulação do Mercado de Capitais. Rio de Janeiro, Instituto. Brasileiro de Mercado de Capitais - IBMEC, 1977. p. 31.

${ }^{39} \mathrm{O}$ mesmo autor, em outra oportunidade, reforçou esta ideia, ao sustentar que "a decisão de regular determinado mercado é, evidentemente, política, estando diretamente relacionada com o modelo econômico do país". EIZIRIK. Nelson Laks. Regulação e auto-regulação do mercado de valores mobiliários. Revista de Direito Mercantil, Industrial, Econômico e Financeiro. São Paulo: $n^{\circ} 48$, ano XXI, out.-dez. 1982. p. 48. No mesmo sentido entende Julian Chediak. In CHEDIAK., Julian Fonseca Peña. A Reforma do Mercado de Valores Mobiliários. In: LOBO, Jorge (org.). A Reforma da lei de Sociedades Anônimas: inovações e questões controvertidas da Lei $n^{\circ} 10.303$, de 31.10.2001. Rio de Janeiro: Forense, 2002. p. 538.
} 
mercado é imperfeito, mas ignoram que o estado também é formado por homens. Constatar imperfeições no mercado não é prova de que intervenções são bem-vindas, tampouco o político é um santo homem iluminado ${ }^{40}$.

Aproximando a discussão sobre as razões por trás da intervenção do Estado no domínio econômico para o tema central do presente trabalho, PRITCHARD traz o exato retrato de como as normas de combate ao insider trading também possuem certo grau de carga política:

Whether the moral outrage over insider trading is driven by a sense of equity or envy, it carries potent political appeal. Coming down hard on insider traders is an easy sell; most voters have no opportunity to engage in insider trading themselves. Once the campaign against insider trading has begun, regulators may lose sight of other priorities. In the United States, the 1980s saw important market players very publicly hauled off in handcuffs, accused of insider trading. The charges were later dropped against many of those arrested (this time without a media presence) for lack of evidence. That minor setback did not hold back the rise of the prosecutor responsible for those arrests, Rudolph Giulani, to political power. The SEC similarly benefited from the high profile attention it has received for its "war" on insider trading. The in terrorem effect of this governmental enthusiasm for pursuing insider traders is difficult to quantify, but it is surely non-trivial ${ }^{41}$.

Por tais motivo, há aqueles que chamam atenção para os malefícios da regulação excessiva, seja pelo fato de os reguladores não serem capazes de prever todos os efeitos que as normas por eles editadas poderão gerar, seja pelo fato de estarem sujeitos à influência - nem sempre benéfica - de determinados grupos de interesses. Além disso, aponta-se que o interesse público que, teoricamente, justificaria a intervenção do Estado na economia, muitas vezes não é atendido pelas agências reguladoras e, portanto, melhor seria adotar a desregulação como política pública. A essa corrente, liderada pelos pensadores liberais, será dedicado o próximo tópico.

\footnotetext{
${ }^{40}$ CONSTANTINO, Rodrigo. Economia do Indivíduo: o legado da Escola Austríaca. São Paulo: Instituto Ludwig von Mises Brasil, 2009. p. 30.

${ }_{41}$ PRITCHARD, Adam. C. Self-Regulation and Securities Market. Disponível em http://ssrn.com/abstract=318939.
} 


\subsection{O pensamento liberal e a Teoria da Captura aplicada à regulação do insider trading}

A Escola Clássica ou Liberal tem como ponto de partida o final do século XVIII, época rica em ideias e realizações em todos os aspectos. Neste período, o comodismo vivido pelo homem, até então, de não ter que tomar decisões sobre o que produzir, como produzir e para quem distribuir os bens produzidos tinha como contrapartida a delegação de sua liberdade ao absolutismo real, sob o manto do direito divino, além da subordinação ao poder da igreja e à nobreza ${ }^{42}$.

Quando o incômodo causado pela exploração dos reis tornou-se maior que o incômodo de deixar o comodismo, iniciou-se uma grande mudança no mundo ocidental, notadamente na Europa Ocidental e nos Estados Unidos. Neste contexto, $\mathrm{HUGON}^{43}$ observa que, dentre as reações iniciadas no fim do século XVII, pôde-se constatar a necessidade de reagir contra a regulamentação abusiva, demonstrada, entre outros, pelos trabalhos de Boisguibert, no seu "Détail de la France" (1679) e "Factum de la France" (1707), e por Duddleuy North, em seu "Discourse upon Trade" (1761).

Entretanto, é somente em meados do século XVIII que começa a se formar um verdadeiro corpo teórico e doutrinário, ao qual se denominou de liberalismo econômico. É neste período, mais precisamente em 1776, que surge na Inglaterra o clássico trabalho de Adam Smith, "A Riqueza das Nações", o qual traz uma revisão das ideias econômicas mercantilistas, influenciando de forma central a formação da chamada Escola Liberal.

De acordo com o pensamento liberal, a atividade econômica deve ser separada da atuação do Estado, cabendo a este apenas zelar pela manutenção

\footnotetext{
${ }^{42}$ ALMEIDA, Luiz Carlos Barnabé de. Introdução ao Direito Econômico. 4. ed. São Paulo: Saraiva, 2012. p. 139.

${ }^{43}$ HUGON, Paul. História das doutrinas econômicas. São Paulo: Atlas, 1995. p. 25.
} 
da paz, da justiça comutativa, pela defesa contra ameaças externas e pela execução dos serviços públicos essenciais, isto é, aqueles que não podem ser conduzidos no âmbito da iniciativa privada.

Os seguidores do pensamento liberal, de uma maneira geral, acreditam que a atividade econômica conduzida autonomamente pelos particulares, sem a intervenção do Estado, permitiria alcançar um nível mais alto de eficiência do que aquele que poderia ser alcançado pelo governo, caso este resolvesse dirigir ou mesmo regular a economia.

\section{Para FRIEDMAN,}

[...] a justificativa paternalista para a atividade estatal é a mais incômoda para um liberal; ela envolve a aceitação de um princípio, o de que alguns podem decidir por outros, que um liberal considera questionável na maioria dos casos e que lhe parece a principal característica de seus principais adversários intelectuais, os defensores do coletivismo em qualquer de suas formas: o comunismo, o socialismo ou o estado do bem-estar social ${ }^{44}$.

As ideais liberais sempre estiveram muito presentes no pensamento econômico dos Estados Unidos, ainda que, em alguns períodos, a intervenção excessiva do Estado neste país tenha quase apagado aquilo que foi um dos pilares da principal economia do mundo. Um destes períodos ocorreu na

\footnotetext{
${ }^{44}$ FRIEDMAN, Milton. Capitalismo e Liberdade. São Paulo: Editora Abril, 1984. p. 18. Cabe advertir, no entanto, que, tanto o modelo liberal quanto o modelo intervencionista comportam ideias opostas à cada um, na medida em que as mesmas contribuam para o aprimoramento do modelo principal. Neste sentido, confira-se as lições de Celso Antônio Bandeira de Mello: "Os Estados que se estruturam ao redor das ideias prestigiadoras da livre iniciativa e da propriedade privada contemplam os casos de protagonização estatal ativa da economia como instrumento ancilar, destinado tão só a estimular a vitalidade econômica ou, então, a evitar que a livre ação dos particulares nesta esfera converta-se em fonte de malefícios para o todo social. Contrariamente, os Estados que se estruturam em torno do coletivismo econômico encarnado no Poder Público, admitem a propriedade privada no circuito da geração e distribuição dos bens, sob disciplina e eventual fomento, como forma secundária, apenas tolerada, na medida em que possa concorrer para ancilar integração da atividade estatal. Em suma: ambos os sistemas valem-se ou podem valer-se das formas que lhes são, em tese, opostas, precisamente enquanto estas servem para coadjuvar os postulados básicos que adotam. Aceitam-nas, pois, 'se', 'enquanto' e 'na medida' em que concorrem para o equilíbrio da forma típica que elegeram para a condução da esfera econômica. Coincidem em que as vias tidas como secundárias são admitidas tão só quando e enquanto colaboram para prestigiar e fortalecer a via principal". MELLO, Celso Antônio Bandeira. O Estado e a Ordem Econômica. Revista de Direito Público RDP 62/34 abr.jun./1982. p. 1.
} 
década de 30 do século passado, no que ficou conhecido como uma das piores, se não a pior, crise financeira da história do sistema capitalista.

Foi durante este período que a "justificativa paternalista para a atividade estatal" a que se referia Milton Friedman foi utilizada como principal ferramenta para introduzir aquilo que ficou conhecido por muitos como a solução para a crise norte-americana de 1929: o New Deal.

Após o crash da Bolsa, muitos estudiosos começaram a propagar a ideia de que o liberalismo econômico havia falhado. Mais do que isso. Para muitos, o liberalismo havia sido a grande causa de todo o mal que assolava a economia americana. É o que retrata REED:

Old myths never die; they just keep showing up in economics and political science textbooks. With only an occasional exception, it is there you will find what may be the $20^{\text {th }}$ century's greatest myth: Capitalism and the free-market economy were responsible for the Great Depression, and only government intervention brought about America's economic recovery.

According to this simplistic perspective, an important pillar of capitalism, the stock market, crashed and dragged America into depression. President Herbert Hoover, an advocate of "hands-off," or laissez-faire, economic policy, refused to use the power of government and conditions worsened as a result. It was up to Hoover 's successor, Franklin Delano Roosevelt, to ride in on the white horse of government intervention and steer the nation toward recovery. The apparent lesson to be drawn is that capitalism cannot be trusted; government needs to take an active role in the economy to save us from inevitable decline. ${ }^{45}$

Neste contexto, em que se buscava uma solução para a crise, sem que se buscasse de fato entender as razões que levaram a ela, diversas medidas intervencionistas foram adotadas por parte do Governo. Uma das mais radicais delas foi a promulgação, em junho de 1933, do National Industrial Recovery Act, que criou a chamada National Recovery Administration, ou NRA, consistente em uma série de códigos e medidas visando tabelar preços e definir as condições em que determinados negócios poderiam ser celebrados.

\footnotetext{
${ }^{45}$ REED, Lawrence W. Great Myths of the Great Depression. Foundation for Economic Education, 2011. p. 1. Disponível em http://c457332.r32.cf2.rackcdn.com/wpcontent/uploads/2011/06/GreatMyths2011FINALweb.pdf .
} 
Para se ter uma ideia das consequências que esta intervenção impensada e apressada do Estado trouxe para a economia dos Estados Unidos à época, $\operatorname{dados}^{46}$ apontam que nos cinco meses anteriores à promulgação da referida lei, os sinais de recuperação eram evidentes: o emprego nas fábricas e as folhas de pagamento haviam aumentado em $23 \%$ e $35 \%$, respectivamente. Veio então o NRA, diminuindo compulsoriamente as horas de trabalho, aumentado salários de forma arbitrária e impondo novos custos aos empresários. O resultado não tardou a aparecer: seis meses após o início das medidas implementadas pelo National Industrial Recovery Act, a produção industrial havia caído $25 \%$.

Conforme observado por ANDERSON, "o NRA não foi uma medida ressuscitadora, mas uma medida anti-ressuscitadora. Durante todo o período do NRA, a produção industrial não foi capaz nem mesmo de crescer até o ponto em que estava em julho de 1933, antes que o NRA fosse implementado"47.

Ainda na esteira das políticas adotadas com o New Deal, o congresso norte-americano aprovou, em 1934, o Securities Exchange Act, lei que, dentre outros assuntos, criou a Securities and Exchange Commission ("SEC") e trouxe as primeiras normas de combate ao insider trading.

Não obstante os méritos da referida lei, fato é que muitos dos dispositivos nela previstos foram pensados e criados dentro deste contexto emergencial em que se inseria todo o pacote de medidas do New Deal, tendo sofrido forte influência da ideia vigente à época de que o liberalismo e a livre economia de mercado haviam fracassado. Entretanto, muitas das leis implementadas pelo New Deal, como o National Industrial Recovery Act e o Agricultural Adjustment Act, além de terem se mostrado economicamente

\footnotetext{
${ }^{46}$ Ibid. p. 11.

${ }^{47}$ No original: "NRA was not a revival measure. It was an antirevival measure. Through the whole of the NRA period industrial production did not rise as high it had been in July 1933, before NRA came in". ANDERSON, Benjamin M. Economics and the Public Welfare: A Financial and Economic History of the United States. $2^{\text {a }}$ Edição. Indianapolis: Liberty Press, 1979. p. 332.
} 
ineficientes e desastrosas, foram posteriormente declaradas inconstitucionais pela Suprema Corte Americana.

Neste contexto, alguns autores que criticam a proibição do insider trading defendem que tal proibição pode ser explicada como um modelo de regulação em que as regras são "vendidas" pelos legisladores e "compradas" por aqueles que se beneficiarão de tais regras. Tais conclusões estão respaldadas por uma das vertentes da Teoria da Regulação, a chamada Teoria da Captura. Em termos simples, para a Teoria da Captura, a regulação não passaria de uma resposta às demandas de grupos de interesse lutando entre si, para maximizar os benefícios de seus membros.

Conforme sintetiza EIZIRIK, a Teoria da Captura, "partindo da ideia de que a regulação é obtida por determinado grupo de interesse, após lutas travadas na arena governamental", sugere que "ao longo do tempo, as agências reguladoras tenderiam a ser dominadas, capturadas pelas indústrias reguladas, que se apresentam como os grupos de interesse mais fortes atuando sobre o processo de elaboração e aplicação da lei" 48 .

Neste sentido, BAINBRIDGE ${ }^{49}$ explica que nos Estados Unidos, país onde surgiram as primeiras normas de combate ao uso de informações privilegiadas, a proibição ao insider trading pode ser explicada de duas formas: em primeiro lugar, como costuma fazer a maioria das agências reguladoras, a SEC desejava expandir sua jurisdição e aumentar seu prestígio. Ao maximizar as receitas recebidas pela autarquia, seus funcionários poderiam igualmente maximizar seus salários, poder e reputação. Um forte programa de repressão contra violações a leis consideradas extremamente chamativas e impopulares representaria um meio efetivo para atrair apoio político.

\footnotetext{
${ }^{48}$ EIZIRIK, Nelson Laks. O papel do Estado na Regulação do Mercado de Capitais. Rio de Janeiro, Instituto. Brasileiro de Mercado de Capitais - IBMEC, 1977. p. 44.

49 BAINBRIDGE, Stephen M. Insider Trading: An Overview. p. 10. Disponível em http://ssrn.com/abstract=132529.
} 
Considerando a substancial atenção dada pela mídia aos casos de insider trading e, ainda, o clamor popular para proibir tal prática, um programa de repressão à negociação com base em informações privilegiadas cumpriria muito bem esse papel.

Em segundo lugar, durante os anos que precederam a edição do Securities Exchange Act de 1934, havia uma grande pressão nos Estados Unidos para federalizar as leis societárias. Assim, visando manter sua prioridade orçamentária frente às demais agências, a SEC desempenhou um papel fundamental no movimento de transferir para esfera federal determinados assuntos que antes eram regulados pelos estados. Neste contexto, a proibição do insider trading representava um alvo ideal para a federalização. Tendo em vista que os estados nunca haviam mostrado um grande interesse em regular a matéria, a regulação federal passou a ser vista como uma medida moderna, flexível e inovadora no combate ao insider trading, tendo a SEC passado a atacar tal prática de forma agressiva. Com isso, a autarquia abriu caminho para transferir para sua competência diversos outros assuntos do direito societário antes regulados pelos estados.

HADDOCK e MACEY ${ }^{50}$ oferecem, ainda, mais uma explicação para a proibição ao insider trading, também baseada na teoria de que tais normas são "vendidas" para aqueles que serão por elas beneficiados. Para tais autores, a proibição ao insider trading é apoiada e dirigida, em grande parte, por profissionais do mercado, um grupo coeso e politicamente influente que se apresenta como o maior beneficiário da referida proibição. Neste ponto, confira-se a explicação de BAINBRIDGE:

Only insiders and quasi-insiders such as lawyers and investment bankers have a greater degree of access to nonpublic information that might affect a firm's stock price than do market professionals. By basing insider trading liability on breach of

\footnotetext{
${ }^{50}$ HADDOCK, David D. e MACEY, Jonathan R. Regulation on Demand: A Private Interest Model,
} with an Application to Insider Trading Regulation. 30 Journal of Law and Economics, 1987. p. 157. 
fiduciary duty, and positing that the requisite fiduciary duty exists with respect to insiders and quasi-insiders but not with respect to market professionals, the prohibition protects the latter's ability to profit from new information about a firm.

Market professionals benefit in a variety of ways from the present ban. When an insider trades on an impersonal secondary market, the insider takes advantage of the fact that the market maker's or specialist's bid-ask prices do not reflect the value of the inside information. Because market makers and specialists cannot distinguish insiders from non-insiders, they cannot protect themselves from being taken advantage of in this way. When trading with insiders, the market maker or specialist thus will always be on the wrong side of the transaction. If insider trading is effectively prohibited, however, the market professionals are no longer exposed to this risk.

Professional securities traders likewise profit from the fiduciary-duty based insider trading prohibition. Because professional investors are often active traders, they are highly sensitive to the transaction costs of trading in securities. Prominent among these costs is the specialist's and market-maker's bid-ask spread. If a ban on insider trading lowers the risks faced by specialists and market-makers, some portion of the resulting gains should be passed on to professional traders in the form of narrower bid-ask spreads.

Analysts and traders are further benefited by a prohibition on insider trading, because only insiders are likely to have systematic advantages over market professionals in the competition to be the first to act on new information. Market professionals specialize in acquiring and analyzing information. They profit by trading with less well-informed investors or by selling information to them. If insiders can freely trade on nonpublic information, however, some portion of the information's value will be impounded into the price before it is learned by market professionals, which will reduce their returns. ${ }^{51}$

Assim, alguns anos após a crise de 1929, e influenciados pelo pensamento liberal, começam a surgir os primeiros trabalhos criticando as normas americanas de combate à negociação com base em informação privilegiada, notadamente o Securities Exchange Act de 1934 e a regulamentação dele decorrente.

Estes estudos, que em sua maioria defendiam, ainda que de diferentes formas, a legalização do insider trading, tiveram como ponto de partida o já mencionado livro de Henry G. Manne, "Insider Trading and the Stock Market", escrito em 1966. Após Manne, diversos foram os autores que se

51 BAINBRIDGE, Stephen M. Insider Trading: An Overview. p. 10-11. Disponível em http://ssrn.com/abstract=132529. 
dedicaram a estudar os efeitos do insider trading sobre o mercado e a propor a sua legalização, dentre eles, Doug Bandow ${ }^{52 / 53}$, William A. Kelly, Jr., Clark Nardinelli, Myles S. Wallace ${ }^{54}$, David D. Haddock ${ }^{55}$, Frank H. Easterbrook e Daniel R. Fischel ${ }^{56}$, e o ganhador do Prêmio Nobel de Economia, Milton Friedman $^{57}$.

Para tais autores, a intervenção do Estado no mercado de capitais operada por meio das normas coibidoras do insider trading seria, no mínimo, ineficiente, uma vez que impediria que os preços dos ativos negociados em tal mercado se formassem adequadamente ${ }^{58}$.

Em última análise, inspirados nas ideias liberais de que ao Estado somente caberia proteger a vida, a saúde e a propriedade de seus cidadãos contra o uso de violência ou fraude ${ }^{59}$, os defensores da legalização do insider trading deram a tal discussão uma roupagem mais econômica, buscando separar questões de ordem moral das questões de ordem técnica.

Nesta análise, os principais proponentes da legalização do insider trading buscaram estudar a regulação do mercado de capitais sob o ponto de

52 BANDOW, Doug. It's time to legalize insider trading. Disponível em http://www.forbes.com/2011/01/20/legalize-insider-trading-economics-opinions-contributors-dougbandow.html.

53 BANDOW, Doug. What's Wrong About Insider Trading? Disponível em: http://www.cato.org/publications/commentary/whats-wrong-about-insider-trading.

54 JR., William A. Kelly; NARDINELLI, Clark; e WALLACE, Myles S. Regulation Of Insider Trading: Rethinking SEC Policy Rules. Massachusetts: Cato Journal (Vol.7, $\mathrm{n}^{\circ}$ 2), 1987.

${ }^{55}$ HADDOCK, David D. Academic Hostility and SEC Acquiescence: Henry Manne's Insider Trading. 50 Case W. Res. L. Rev. 313 1999-2000.

${ }^{56}$ EASTERBROOK, Frank H.; FISCHEL, R. Daniel. The economic structure of corporate law. Cambridge: Harvard University Press, 1996. p. 253 e ss.

${ }^{57}$ Em entrevista concedida à rede de televisão americana CNBC em março de 2003, Milton Friedman traz diversos argumentos a favor da legalização do insider trading. Em determinada passagem da entrevista, Friedman afirma: "Pessoas estão indo para a cadeia acusadas de insider trading e eu acho que isso tem sido um grande erro. Você quer mais insider trading, não menos. Você quer dar às pessoas que possuem acesso mais fácil às deficiências de uma companhia um incentivo para que elas deixem o público ciente disso" (tradução livre). Disponível em http://www.thehindubusinessline.in/2003/09/17/stories/2003091701330900.htm.

${ }^{58}$ Estes e outros argumentos serão explicados com mais detalhes no Capítulo 6 deste trabalho.

${ }^{59}$ MISES, Ludwig Von. Intervencionismo - Uma análise econômica. São Paulo: Instituto Ludwig von Mises Brasil, 2010. p. 27. 
vista da escola do law and economics, visando identificar as normas que se mostram mais economicamente eficientes.

\subsection{A escola do law and economics e a busca pela regulação economicamente eficiente}

De acordo com SZTAJN, "comum aos estudos de law and economics é a percepção da importância de recorrer a alguma espécie de avaliação ou análise econômica na formulação de normas jurídicas visando a torna-las cada vez mais eficientes"

Neste contexto, a escola da análise econômica do direito - também conhecida como law and economics scholarship -, apesar de ainda pouco difundida no Brasil ${ }^{61}$, apresenta-se como mais um elemento a contribuir na busca por uma regulação mais eficiente, que legitime a intervenção estatal no domínio econômico.

A escola do law and economics pode ser definida como o movimento contemporâneo que combina as ciências econômica e jurídica numa tentativa de estudo interdisciplinar, tendo como característica comum, sem distinguir tendências e escolas, a aplicação de teoria microeconômica neoclássica do bem-estar para analisar e reformulação tanto das instituições particulares como do sistema jurídico em seu conjunto ${ }^{62}$.

\footnotetext{
${ }^{60}$ SZTAJN, Rachel. Law and Economics. Revista de Direito Mercantil, Industrial, Econômico e Financeiro. São Paulo: ${ }^{\circ}$ 137, ano XLIV, jan.-mar. 2005. p. 228. De acordo com a autora, "eficiência" pode ser entendida como a "aptidão para obter o máximo ou melhor resultado ou rendimento, com a menor perda ou o menor dispêndio de esforços".

${ }^{61}$ De acordo com Rachel Sztajn, uma das razões para tal resistência seria o fato de que no Brasil, por ser um país onde o direito encontra-se filiado à família romano-germânica, predominariam a dogmática, a discussão e classificação das fontes do direito, expostas de maneira sistemática para desenhar um conjunto coerente, que não segue a metodologia adotada pelos economistas baseada na análise de esquemas empíricos. Ibid. p. 227.

${ }^{62}$ PACHECO, Pedro Mercado. El Análisis Económico del Derecho- una reconstrucción teórica. Madrid: Cento de Estudios Constitucionales, 1994 p. 25; 174.
} 
Apesar de os estudos sobre os efeitos econômicos das normas jurídicas terem se iniciado já no século XVIII com os trabalhos de Adam Smith e Jeremy Betham, a escola da análise econômica do direito passa a se desenvolver de forma mais acentuada a partir do final da década de 60, ganhando corpo nos trabalhos de Ronald H. Coase $^{63}$ e Guido Calabresi ${ }^{64}$, e tendo recebido novo impulso em 1973 com as publicações de Richard Posner ${ }^{65}$.

Juntamente com tais autores, o principal defensor da legalização do insider trading, Henry G. Manne, foi considerado pela American Law and Economics Association como um dos quatro fundadores da law and economics scholarship.

Conforme observa CASS ${ }^{66}$, "Manne foi um dos primeiros doutrinadores a se utilizar da ciência econômica para criar uma nova visão sobre um conceito legal e a fazer isso de forma a impactar drasticamente as discussões sobre o assunto".

Em sua pioneira e já citada obra, "Insider Trading and the Stock Market", MANNE dá a exata dimensão de como o debate que cercava a negociação com base em informações privilegiadas, já àquela época, carecia de uma análise sob o enfoque do law and economics:

63 "The Problem of Social Cost" (Journal of Law and Economics, n.3, 1960), no qual são analisados os problemas do custo social ou efeitos externos produzidos pelas atividades econômicas com críticas ao papel intervencionista do Estado e ênfase na inconsistência da economia de bem-estar.

64 "Some Thougts on Risk Distribution and the Law of Torts" (Yale Law Journal, vol.68, 1961), em que se examina, sob a ótica da teoria econômica, a distribuição do risco como critério de imputação da responsabilidade que informa o direito de danos.

65 "Economic Analisys of Law" (1973), que consolida o movimento da análise econômica do direito, apresentando um estudo sistemático da maioria dos setores do sistema jurídico americano, desde a perspectiva da análise econômica e discorrendo sobre as principais teses da tendência predominante polarizada na Escola de Chicago e consistente na teoria positiva do sistema jurídico desde a perspectiva do paradigma do mercado e da eficiência econômica.

${ }^{66}$ CASS, Ronald A. One Among the Manne: Changing our Course, 50 Case W. Res. L. Rev. 203, 204 (1999). 
From the beginning the subject of insider trading has been almost exclusively the province of lawyers and law professor. There is a rich economic literature that may be drawn on for understanding the problems, but economists, almost to the man, have remained silent on this specific question. ${ }^{67}$

MANNE estabelece, então, a principal diferença entre economistas e advogados - quando a escola da análise econômica do direito ainda era incipiente - ao enfrentar a questão do insider trading:

The fundamental approach of lawyers to issues such as this one is quite different from that of economists. The lawyers' approach to most questions reflects the centuries-old tradition of viewing problems in the context of a case or lawsuit, the arena for settling disputes between two live, human beings.

\section{$[\ldots]$}

Thus when lawyers, judges and law professors are faced with issues of broad social economic consequences, their tendency is to approach the subject with relationships between specific individuals in mind. Their acceptance or rejection of a practice will reflect their notion of the fairness of the transaction simply from the point of view of the two individuals involved. It is not difficult to see why lawyers have generally concluded that there is something unfair (primarily in the sense of 'unequal') about insiders with undisclosed good news buying shares from existing shareholders.

\section{$[\ldots]$}

The question for an economist is rarely one of the mutual fairness of a transaction between individual parties. He is not a specialist in matters of individual morality [...]. The economist, viewing the issue of insider trading, will ask how all shareholders are affected financially by the practice, whether it results in a desirable allocation of resources, and whether the return to insiders reflects a competitive or a monopoly gain. ${ }^{68}$

Traçando esta diferenciação entre a forma de enxergar a negociação com base em informações privilegiadas por parte de juristas e economistas, Manne abriu as portas para uma nova abordagem do insider trading, buscando analisar a questão sob uma ótica pouco explorada até então.

No entanto, para que se possa promover um estudo do insider trading sob a perspectiva oferecida por Manne e pelos demais autores que o seguiram, faz-se necessário analisar, primeiramente, os principais aspectos do mercado

\footnotetext{
${ }^{67}$ MANNE, Henry G., Insider Trading and the Stock Market. New York: Free Press, 1966. p. 2.

${ }^{68}$ Ibid. p. 2-3.
} 
de capitais brasileiro e os objetivos de sua regulação, visando identificar como o combate ao uso de informações privilegiadas se insere dentro do atual quadro regulatório do país. 


\section{CAPÍTULO 3 - A REGULAÇÃO DO MERCADO DE CAPITAIS E AS CONDIÇÕES PARA SEU ADEQUADO FUNCIONAMENTO}

\subsection{Conceito de mercado de capitais}

Nas lições de EASTERBROOK e FISCHEL, “'markets' are economic interactions among people dealing as strangers and seeking personal advantage",69.

EINAUDI $^{70}$ complementa o conceito, definindo "mercado" como o local em que compradores e vendedores de bens, tomadores e prestadores de serviços, se encontram para negociar referidos bens e serviços. Ainda segundo o autor italiano, para caracterização de um mercado, deve existir um número significativo de compradores e vendedores potenciais competindo entre si permitindo, assim, a formação de preços. Além disso, esses agentes devem ser livres para realizar ou deixar de realizar as operações, de acordo com as suas necessidades $^{71}$.

De acordo com EIZIRIK ${ }^{72}$, a expressão "mercado de capitais" comporta definições amplas e estreitas: no primeiro caso, referido mercado é equiparado ao mercado financeiro; no segundo, o mercado de capitais é visto como um

${ }^{69}$ EASTERBROOK, Frank H.; FISCHEL, R. Daniel. The economic structure of corporate law. Cambridge: Harvard University Press, 1996. p. 8

${ }^{70}$ EINAUDI, Luigi. Lezione di Politica Sociale. Torino: Giulio Einaudi Editore, 1950. p. 5 e ss. Apud YAZBEK, Otávio. Regulação do mercado financeiro e de capitais. Rio de Janeiro: Elsevier, 2009. p. 187/188.

${ }^{71}$ Para uma análise da natureza humana do mercado, remeto a Ludwig von Mises: “O mercado não é um local, uma coisa, uma entidade coletiva. O mercado é um processo, impulsionado pela interação das ações dos vários indivíduos que cooperam sob o regime da divisão do trabalho. As forças que determinam a - sempre variável - situação do mercado são os julgamentos de valor dos indivíduos e suas ações baseadas nesses julgamentos de valor. A situação do mercado num determinado momento é a estrutura de preços; isto é, o conjunto de relações de troca estabelecido pela interação daqueles que estão desejosos de vender com aqueles que estão desejosos de comprar. Não há nada, em relação ao mercado, que não seja humano, que seja místico. O processo de mercado resulta exclusivamente das ações humanas. Todo fenômeno de mercado por ser rastreado até as escolhas específicas feitas pelos membros da sociedade de mercado." MISES, Ludwig von. Ação Humana: um Tratado de Economia, trad. de Donald Stewart Jr., Rio de Janeiro: Instituto Liberal, 1990. p. 256-257.

${ }^{72}$ EIZIRIK, Nelson Laks. O papel do Estado na Regulação do Mercado de Capitais. Rio de Janeiro, Instituto. Brasileiro de Mercado de Capitais - IBMEC, 1977. p. 27. 
subsistema do mercado financeiro ${ }^{73}$, representando aquilo que, no Brasil, recebeu o nome, em termos legais ${ }^{74}$, de "mercado de valores mobiliários" ${ }^{\text {"75 }}$. No presente trabalho, as expressões "mercado de capitais" e "mercado de valores mobiliários" serão usadas como sinônimos e com base nesta segunda definição.

SZTAJN, por sua vez, complementa referida definição, entendendo por "mercado de valores mobiliários" "aquele em que o conjunto de operações nele contratadas tem como bens objeto, ações, debêntures ou outros títulos admitidos à negociação em bolsa ou balcão organizado [... $]^{376}$.

O mercado de capitais também pode ser entendido como o mercado de desintermediação bancária, na medida em que as instituições financeiras figuram neste mercado como meros intervenientes entre o investidor e o tomador de recursos ${ }^{77}$.

Neste ponto, vale conferir as lições de CHEDIAK:

No mercado de valores mobiliários a transferência dos recursos financeiros é realizada de forma direta. Não existe intermediação efetiva (existe, quase sempre, a participação de um intermediário financeiro, mas tal intermediário não age em nome próprio). Quando uma companhia emite publicamente uma ação, apesar de ser obrigatória a participação de uma instituição financeira na operação, do ponto de

\footnotetext{
${ }^{73}$ Note-se, no entanto, que outros autores dão uso diverso para a expressão "mercado de capitais". Em artigo sobre a estrutura de supervisão do mercado de capitais no Brasil, Marcelo Trindade utiliza a expressão "mercado de capitais" para englobar os mercados bancário (ou financeiro), de valores mobiliários, de seguros, capitalização e de previdência complementar privada, aberta ou fechada. TRINDADE, Marcelo. A Revisão da Estrutura de Supervisão do Mercado de Capitais no Brasil. Rio de Janeiro: Grupo de Trabalho de Estudos Regulatórios, ANBIMA. p. 1.

74 Basta conferir o preâmbulo da Lei $\mathrm{n}^{\circ}$ 6.385/76, que usa a expressão "mercado de valores mobiliários". Ainda na referida lei, podem ser encontradas 18 (dezoito) referências ao termo "mercado de valores mobiliários", tais como: Art. $1^{\circ}$, II; Art. $3^{\circ}$, I; Art. 4, IV, “c"; dentre outros.

${ }^{75}$ Siegfried Kümpel sustenta, inclusive, que os termos "mercado de capitais" e "mercado de valores mobiliários" são sinônimos. KÜMPEL, Siegfried. Direito do Mercado de Capitais - do ponto de vista do direito europeu, alemão e brasileiro - introdução. Rio de Janeiro: Renovar, 2007. p. 44.

${ }^{76}$ SZTAJN, Rachel. Conceito de liquidez na disciplina do mercado de valores mobiliários. Revista de Direito Mercantil, Industrial, Econômico e Financeiro. São Paulo: $n^{\circ}$ 126, ano XLI, abr.-jun. 2002. p. 12.

${ }^{77}$ MOSQUERA, Roberto Quiroga. Os Princípios Informadores do Direito do Mercado Financeiro e de Capitais. In: MOSQUERA, Roberto Quiroga (org.). Aspectos Atuais do Direito do Mercado Financeiro e de Capitais. São Paulo: Dialética, 1999. p. 260.
} 
vista jurídico, o subscritor adquire a ação diretamente da companhia. A relação jurídica entre aplicador e tomador é direta.

Em resumo, no mercado de valores mobiliários, as instituições especializadas têm função de aproximação, [...]. ${ }^{78}$ (grifos do original)

$\mathrm{Na}$ doutrina estrangeira, BERLE e MEANS oferecem uma interessante definição de mercado de valores mobiliários:

Security markets are of all gradations, though the underlying idea is always the same. They are meeting places for buyers and sellers. In fact, however, they are more than this. They are points at which there are always purchasers prepared to buy at some price and sellers prepared to sell at some price. In other words, a security market contemplates that at all times there shall be stock offered for sale at a price and purchasers ready to take, at a price, stock which might be offered. When either of these requisites ceases to exist there is no market. The process must be continuous i.e., the exigency must never arise when there is a buyer with no seller or a seller with no buyer. ${ }^{79}$

Pode-se dizer que a função econômica essencial do mercado de valores mobiliários é a de aproximar a unidade econômica deficitária - a entidade emissora - e a unidade econômica superavitária - o investidor, permitindo que as empresas, mediante a emissão pública de seus valores mobiliários, captem recursos não exigíveis para financiar e viabilizar seus projetos de investimento ou até mesmo para alongar o prazo de suas dívidas.

EIZIRIK traz, ainda, outras 5 (cinco) funções econômicas relevantes desempenhadas pelo mercado de valores mobiliários, a saber:

1) conciliação do interesse do poupador de oferecer recursos a curto prazo (quando os valores mobiliários são dotados de liquidez) com a necessidade da empresa emissora de obter recursos de médio e longo prazos;

2) transformação dos montantes de capital, de sorte que pequenos e médios montantes de recursos, aportados por diferentes poupadores, convertem-se, por ocasião da subscrição de valores mobiliários, em grandes e consolidados montantes de capital;

3) transformação da natureza dos riscos, ao permitir que se transforme uma série de investimentos de alto risco individual, de longo prazo e sem liquidez, em investimentos com maior segurança e prazos mais curtos;

\footnotetext{
${ }^{78}$ CHEDIAK., Julian Fonseca Peña. A Reforma do Mercado de Valores Mobiliários. In: LOBO, Jorge (org.). A Reforma da lei de Sociedades Anônimas: inovações e questões controvertidas da Lei $n^{\circ}$ 10.303, de 31.10.2001. Rio de Janeiro: Forense, 2002. p. 531.

${ }^{79}$ BERLE, Adolf Augustus. MEANS, Gardiner Coit. The modern corporation and private property. New Brunswick: Transaction Publishers, 2009. p. 256
} 
4) maior agilidade do processo de transferência dos recursos, uma vez que os valores mobiliários (ações, debêntures, etc.) são padronizados e aptos a circularem em massa; 5) obtenção de um maior volume de informações homogêneas sobre a oferta e demanda de recursos. ${ }^{80}$

No que se refere ao seu funcionamento, o mercado de capitais pode ser dividido em mercado primário e mercado secundário. A compreensão dos conceitos de mercado primário e secundário mostra-se relevante, pois, como se verá adiante, os efeitos do insider trading podem ser sentidos em ambos os segmentos de mercado.

O mercado primário é aquele onde ocorrem as emissões públicas de novos valores mobiliários, mediante captação da poupança popular. Os recursos obtidos com a aquisição de valores mobiliários pelos investidores são direcionados diretamente para as entidades emissoras, que poderão, dessa forma, utilizá-los em seus projetos de investimento.

No entanto, observa EIZIRIK ${ }^{81}$, “a existência do mercado primário seria extremamente prejudicada se, após subscreverem os novos valores mobiliários emitidos, os investidores não tivessem condições de negociá-los com terceiros".

Assim, no mercado secundário, os valores mobiliários emitidos são negociados entre os próprios poupadores, seja por meio da bolsa de valores, futuros e mercadorias, seja por meio do chamado mercado de balcão. Tais entidades têm a função de facilitar as negociações, organizando, mantendo, e fiscalizando um local e/ou sistema adequado e seguro para as operações com valores mobiliários.

\footnotetext{
${ }^{80}$ EIZIRIK, Nelson Laks; GAAL, Ariádna B.; PARENTE, Flávia; HENRIQUES, Marcus de Freitas. Mercado de Capitais - regime jurídico. 2. ed. (revisada e atualizada). Rio de Janeiro: Renovar, 2008. p. 9.

${ }^{81}$ Ibid. p. 193.
} 
Dessa forma, no mercado secundário não há entrada de novos recursos para as companhias emissoras. Entretanto, este segmento desempenha um papel fundamental na lógica de investimento do mercado de capitais, conferindo liquidez aos valores mobiliários emitidos e permitindo que seus adquirentes os vendam rapidamente.

Esta complexa estrutura sobre a qual se sustenta o mercado de capitais brasileiro está sujeita a uma série de normas visando regular a relação entre os diversos participantes deste mercado.

Neste contexto, o entendimento da doutrina majoritária costuma atribuir ao regulador um importante papel, apontando-o como o responsável por manter o regular funcionamento do mercado, e ignorando, ou dando pouca importância, aos possíveis efeitos prejudiciais que a regulação excessiva pode trazer.

Veja-se, neste ponto, o que sustenta LAMY:

[...] entre a S/A fechada - mera técnica de estruturar um negócio, que poderia eventualmente revestir qualquer outra forma societária - e a S/A aberta - cujos títulos alimentam o mercado de capitais, que apela para o público em busca do capital de risco de que necessita (como vai à rede bancária obter o financiamento em capital empréstimo), - a diferença não é apenas de tamanho ou de grau, é de natureza. Quando uma S/A resolve abrir seu capital ela não pratica, apenas, um mero ato de economia interna de empresa: ela aciona mecanismos de crédito público, por cuja idoneidade e regular funcionamento deve responder o Governo, como Minister Dei in bonum, na velha expressão tomística. ${ }^{82}$ (grifos nossos)

Independentemente da discussão já apresentada acima a respeito da intensidade adequada com a qual o regulador deveria dirigir a economia e o mercado, fato é que, atualmente, prevalece o entendimento de que ao Estado cabe responder pelo regular funcionamento do mercado de capitais.

\footnotetext{
${ }^{82}$ FILHO, Alfredo Lamy. A Reforma da Lei das Sociedades Anônimas. Revista de Direito Mercantil, Industrial, Econômico e Financeiro. São Paulo: n 7, ano XI, 1972. p. 125.
} 
Assim, e considerando, conforme visto anteriormente, que a decisão de regular determinado mercado é essencialmente política e está constantemente sujeita a erros de julgamento, faz-se necessário analisar, ainda que brevemente, os objetivos e princípios da regulação do mercado de capitais traçados na legislação e que devem pautar a atuação do regulador.

\subsection{Objetivos e princípios da regulação do mercado de capitais brasileiro}

A compreensão dos objetivos e princípios da regulação do mercado de capitais brasileiro mostra-se de suma importância para o presente trabalho, uma vez que é a partir destes objetivos e princípios que toda a legislação de combate ao insider trading se origina, notadamente após 2001, quando a Lei ${ }^{\circ}$ 6.385/76 foi modificada para, dentre outras mudanças, incluir como objetivo expresso da regulação do mercado de capitais o combate ao "uso de informação relevante não divulgada no mercado de valores mobiliários" ${ }^{" 83}$.

A exposição de motivos da Lei ${ }^{\circ} 6.385 / 76$, a qual criou a Comissão de Valores Mobiliários e instituiu o novo marco regulatório do mercado de capitais brasileiro, dá a exata medida da intenção do legislador ao editar a norma que viria a regular referido mercado:

A experiência demonstrou que a defesa da economia popular e o funcionamento regular do mercado de capitais exigem a tutela do Estado, com a fixação de normas para emissão de títulos destinados ao público, divulgação de dados sobre a companhia emitente e negociação dos títulos no mercado. Além disso, é necessário que agência governamental especializada exerça as funções de polícia do mercado, evitando as distorções e abusos a que está sujeito. ${ }^{84}$

Nessa linha, o Art. $4^{\circ}$ da Lei ${ }^{\circ} 6.385 / 76$ estabelece:

Art. $4^{\circ} \mathrm{O}$ Conselho Monetário Nacional e a Comissão de Valores Mobiliários exercerão as atribuições previstas na lei para o fim de:

I - estimular a formação de poupanças e a sua aplicação em valores mobiliários;

\footnotetext{
${ }^{83}$ Tal objetivo encontra-se expressamente previsto no Art. $4^{\circ}$, IV, "c" da Lei n ${ }^{\circ} 6.385 / 76$.

${ }^{84}$ Publicada em Diário Oficial no dia 10 de agosto de 1976, p. 6.974.
} 
II - promover a expansão e o funcionamento eficiente e regular do mercado de ações, e estimular as aplicações permanentes em ações do capital social de companhias abertas sob controle de capitais privados nacionais;

III - assegurar o funcionamento eficiente e regular dos mercados da bolsa e de balcão; IV - proteger os titulares de valores mobiliários e os investidores do mercado contra:

a) emissões irregulares de valores mobiliários;

b) atos ilegais de administradores e acionistas controladores das companhias abertas, ou de administradores de carteira de valores mobiliários.

c) o uso de informação relevante não divulgada no mercado de valores mobiliários.

V - evitar ou coibir modalidades de fraude ou manipulação destinadas a criar condições artificiais de demanda, oferta ou preço dos valores mobiliários negociados no mercado;

VI - assegurar o acesso do público a informações sobre os valores mobiliários negociados e as companhias que os tenham emitido;

VII - assegurar a observância de práticas comerciais equitativas no mercado de valores mobiliários;

VIII - assegurar a observância no mercado, das condições de utilização de crédito fixadas pelo Conselho Monetário Nacional.

Ao delinear as finalidades da atuação da Comissão de Valores Mobiliários e do Conselho de Recursos do Sistema Financeiro Nacional, o legislador brasileiro contribuiu para uma melhor compreensão dos objetivos e princípios básicos que devem nortear a atuação dos órgãos reguladores deste mercado.

\section{Neste ponto, TAVARES GUERREIRO ensina que}

[n]essa enumeração programática e valorativa, encontram-se os fins justificadores do poder disciplinar da CVM, por consubstanciarem os próprios objetivos da autarquia. Isso equivale a dizer que o exercício do poder disciplinar somente se legitima na medida em que visa assegurar a consecução daqueles mesmos fins. ${ }^{85}$

\section{A International Organization of Securities Commissions ("IOSCO") ${ }^{86}$,}

por meio de trabalho publicado em 1998 e atualizado em 2010, intitulado

Objectives and Principles of Securities Regulation, elenca 3 (três) objetivos da regulação do mercado de capitais e 38 (trinta e oito) princípios que buscam

\footnotetext{
${ }^{85}$ GUERREIRO, José Alexandre Tavares. Sobre o poder disciplinar da CVM. Revista de Direito Mercantil, Industrial, Econômico e Financeiro. São Paulo: n ${ }^{43}$, ano XX, 1981. p. 56-57

${ }^{86}$ A IOSCO reúne as comissões de valores mobiliários de 115 (cento e quinze) países, dentre eles, o Brasil, que faz parte do Conselho Transitório. A IOSCO é reconhecida como a entidade criadora dos padrões internacionais para o mercado de valores mobiliários, criada e operada sem qualquer tipo de tratado internacional, diretamente por agências governamentais e não por chefes de estado, ministros das relações exteriores ou diplomatas.
} 
implementar esses objetivos ${ }^{87}$. A IOSCO entende que, embora existam características particulares de cada jurisdição, os seguintes objetivos formam a base de um sistema eficaz de regulação do mercado de valores mobiliários: (i) proteção dos investidores; (ii) assegurar mercados equitativos, eficientes e transparentes; e (iii) redução do risco sistêmico ${ }^{88}$.

Em sentido semelhante, EIZIRIK ${ }^{89}$ apresenta 5 (cinco) objetivos ${ }^{90}$ que, em seu entendimento, devem nortear a regulação do mercado de capitais. São eles: (i) proteção aos investidores; (ii) eficiência do mercado; (iii) criação e manutenção de instituições confiáveis e competitivas; (iv) evitar concentração do poder econômico; e (v) impedir a criação de situações de conflito de interesses.

Para fins do presente trabalho, os objetivos que estão mais diretamente relacionados às normas de combate ao insider trading e que serão aqui desenvolvidos são aqueles que buscam a proteção do investidor e a eficiência do mercado.

Em certa medida, a proteção ao investidor - aquele que aplica seus recursos financeiros nos valores mobiliários emitidos publicamente e

\footnotetext{
${ }^{87}$ Através dessa publicação, os membros da IOSCO expressaram a intenção de usar de seus melhores esforços para assegurar a convergência da regulação nacional de seus mercados de capitais aos objetivos e princípios elencados. Esse compêndio também é utilizado pelo Fundo Monetário Internacional (FMI) e pelo Banco Mundial para avaliar o mercado de capitais de países sob análise. Em teoria, na medida em que existam conflitos entre a regulação do mercado de capitais de um país e os Princípios da IOSCO, o Banco Mundial e o FMI poderiam condicionar o empréstimo de recursos financeiros à reforma da regulação. Portanto, embora a IOSCO não crie direito internacional, os princípios e objetivos traçados pela IOSCO são seriamente considerados pelos membros da organização. KINGSBURY, B.; KRISCH, N.; e STEWART, R. B. The emergence of Global Administrative Law. Disponível em http://ssrn.com/abstract=692628.

${ }^{88}$ IOSCO (2010). Objectives and Principles of Securities Regulation. p. 12. Disponível em www.iosco.org.

${ }^{89}$ EIZIRIK, Nelson Laks; GAAL, Ariádna B.; PARENTE, Flávia; HENRIQUES, Marcus de Freitas. Mercado de Capitais - regime jurídico. 2. ed. (revisada e atualizada). Rio de Janeiro: Renovar, 2008. p. 18.

${ }^{90}$ Note-se que o que alguns autores entendem como objetivos da regulação do mercado de capitais, outros designam como princípios. No entanto, como a linha de diferenciação torna-se muito tênue em alguns casos, optamos, apenas para fins de clareza, por adotar a classificação trazida por Nelson Eizirik.
} 
negociados no mercado - está intimamente ligada à proteção da própria saúde do mercado. Isso porque os investidores devem poder acreditar que seus retornos em aplicações no mercado de capitais estarão razoavelmente ligados aos riscos dos investimentos. Caso contrário, tenderão a não aplicar, ou a retirar seus recursos deste segmento de mercado buscando outras opções de investimento $^{91}$.

Neste sentido, confira-se as lições de GILLEN:

In a competitive capital market, savings should be allocated to investments that provide the highest rate of return for a given level of relevant risk. Where securities prices in a capital market do not accurately reflect returns on the securities and the relevant risk associated with those returns, there will be a misallocation of savings to investment. Market failures in a capital market may cause investors to demand higher returns to compensate for potential losses associated with the market failures. This raises the cost of capital for issuers, causing them to reduce investment in productive activities with consequent effects on the economy. If the capital market is less competitive than capital markets in other jurisdictions, issuers will have an incentive to raise capital in those other jurisdictions, thereby incurring a lower cost of capital. ${ }^{92}$

Não se quer dizer que a regulação deve eliminar por completo os riscos, pois eles são inerentes ao mercado de capitais. Por outro lado, para parte majoritária da doutrina, a regulação pode desempenhar um papel fundamental na diminuição de riscos derivados de comportamentos ilícitos, ou seja, comportamentos que tornem artificiais as cotações dos títulos negociados e que abalem a confiança dos investidores ${ }^{93}$.

\footnotetext{
${ }^{91}$ Conforme observado por Sofia Nascimento Rodrigues, "segurança do investimento e a confiança no mercado, são, portanto, condições essenciais ao regular funcionamento deste, pois dela depende a decisão do investidor no sentido de aplicar, neste mercado, as suas poupanças". RODRIGUES, Sofia Nascimento. Proteção dos Investidores em Valores Mobiliários. Coimbra: Almedina, 2001. p. 26.

92 GILLEN, Mark. The Role of Securities Regulation in Promoting a Competitive Capital Market. Victoria: Task Force to Modernize Securities Legislation in Canada, 2006. p. 12. Disponível em http://www.tfmsl.ca/docs/V4(1)\%20Gillen.pdf.

${ }_{93}$ Conforme observado por Andrew Sheng, "people don't buy a product: they buy a promise. As a lawyer or issuer, you offer a service or product that must contain a promise of quality. This muts be true of securities markets, as in all other markets. You prefer one product or market to another because of the promise of quality - if the investor or consumer is disappointed, he or she will simply go to another product, producer or market". SHENG, Andrew. Disclosure Regulation: The Role of Intermediaries. Asia Pacific In-House Counsel Summit, 2004. p. 1.
} 
Como se verá adiante, dentre tais comportamentos, parte majoritária da doutrina jurídica e econômica elenca a negociação com base em informações privilegiadas ${ }^{94}$. Logo, sua proibição representaria uma das principais proteções que poderia se conferir aos investidores. No entanto, a corrente do law and economics liderada por Henry G. Manne sustenta que o insider trading não representa uma ameaça aos investidores. Pelo contrário, os investidores estariam mais protegidos, ou seja, negociariam em melhores condições de mercado se o uso de informações privilegiadas fosse permitido.

Em todo caso, independentemente da corrente a ser adotada quanto aos efeitos benéficos ou maléficos do insider trading, fato é que a proteção aos investidores figura como um dos principais objetivos da regulação do mercado de capitais.

O segundo objetivo da regulação do mercado de capitais intimamente ligado à discussão do combate ao insider trading é a busca por um mercado eficiente.

Nas lições de FAMA 95 , "mercado eficiente" seria o mercado no qual os preços sempre refletem precisamente as informações disponíveis.

De acordo com BOULOS e SZTERLING, o princípio da eficiência pode ser entendido como

[...] um princípio jurídico de natureza programática cuja finalidade maior é aproximar o mercado de capitais da concorrência perfeita. Em atendimento a esse princípio, o CMN, a CVM e as Bolsas de Valores, como órgãos reguladores, devem prover o mercado de capitais com meios físicos, os mecanismos e o arcabouço normativo que tornem a cotação dos valores mobiliários o mais próxima possível do efetivo valor

\footnotetext{
${ }^{94}$ A IOSCO também entende que a proteção aos investidores está intimamente ligada às normas de combate ao insider trading: "Investors should be protected from misleading, manipulative or fraudulent practices, including insider trading, front running or trading ahead of customers and the misuse of client assets". IOSCO (2008). Objectives and Principles of Securities Regulation. p. 12. Disponível em www.iosco.org.

${ }^{95}$ FAMA, Eugene F. Efficient Capital Markets: A Review of Theory and Empirical Work. The Journal of Finance, v. 25, n. 2, p. 383-417, May 1970.
} 
das companhias emissoras, bem como que reduzam os custos das transações entre os investidores. ${ }^{96}$

Nesta linha, a doutrina majoritária sustenta que a negociação com base em informações privilegiadas tenderia a reduzir o nível de eficiência do mercado, uma vez que determinado grupo de pessoas negociaria com base em informações não disponíveis ao público e, portanto, não refletidas na cotação dos valores mobiliários negociados. Em sentido oposto, os defensores do insider trading argumentam que o uso de informações privilegiadas conferiria maior eficiência ao mercado, uma vez que informações ainda não divulgadas poderiam ser incorporadas ao preço dos valores mobiliários de forma mais rápida caso aqueles que as possuíssem pudessem com base nelas negociar. De todo modo, assim como a proteção aos investidores, a busca pela eficiência do mercado se mostra presente independentemente da corrente adotada.

Nota-se, assim, que tanto a proteção dos investidores quanto a busca por um mercado de capitais eficiente estão intimamente relacionados à legislação de disclosure, isto é, às regras que exigem a ampla e completa divulgação de informações pelos emissores de valores mobiliários no mercado de capitais.

Dessa forma, mostra-se relevante verificar como as discussões sobre a assimetria informacional e o princípio do full and fair disclosure relacionam-se com as questões envolvendo a negociação com base em informações privilegiadas.

\subsection{Assimetria informacional e seleção adversa}

Ressaltando a importância da informação para o mercado, SHENG anota:

\footnotetext{
96 BOULOS, Eduardo Alfred Taleb; e SZTERLING, Fernando. O Novo Mercado e as Práticas Diferenciadas de Governança Corporativa: Exame de Legalidade Frente aos Poderes das Bolsas de Valores. Revista de Direito Mercantil, Industrial, Econômico e Financeiro. São Paulo: $\mathrm{n}^{\circ}$ 125, ano XXII, abr.-jun. 1983.
} 
Information is a market fundamental. By and large, small investors cannot control or even influence the management of a company they invest in, but they should be entitled to the material, accurate, complete and timely information to judge whether to invest or divest in a particular company. ${ }^{97}$

Com efeito, TRINDADE ${ }^{98}$ aponta que a informação é o principal bem jurídico tutelado pela intervenção estatal no mercado de capitais.

Para MANNE, o mercado de capitais pode ser entendido como um mercado de informações valiosas, ou na expressão em inglês, " $a$ market for valuable information". Neste ponto, referido autor observa:

In many respects the entire stock market is a complex arrangement for the marketing of information. In an investment market characterized by great risks a high premium will normally be paid for reliable information. In a market more stable and less subject to fluctuations, the difference in rate of return to the more informed and the less informed participants becomes smaller [...]. As a market is subjected to more uncertainty, information about the possibility of change and its actual occurrence become more valuable. The different amounts of profit of different individuals will reflect their different degrees of sophistication and the reliability of their information. The stock market is, par excellence, the arbiter of the value of information. ${ }^{99}$ (grifo nosso)

Como já referido, o mercado de capitais só seria alocativamente eficiente se a cotação ${ }^{100}$ dos valores mobiliários sofresse reflexos imediatos advindos das informações disponíveis sobre as companhias emissoras e dos

${ }^{97}$ SHENG, Andrew. Disclosure Regulation: The Role of Intermediaries. Asia Pacific In-House Counsel Summit, 2004. p. 1.

${ }_{98}$ TRINDADE, Marcelo F. O Papel da CVM e o Mercado de Capitais. In: JAIRO SADDI (org.). Fusões e Aquisições: Aspectos Jurídicos e Econômicos. São Paulo: IOB, 2002. p.308

${ }^{99}$ MANNE, Henry G., Insider Trading and the Stock Market. New York: Free Press, 1966. p. 47.

${ }^{100}$ Sobre a formação dos preços em um determinado mercado, confira-se as lições de Ludwig von Mises: "Os preços se constituem, em última instância, por julgamentos de valor dos consumidores. São o resultado da valoração, do ato de preferir 'a' a 'b'. São um fenômeno social, na medida em que são consequência da interação das valorações de todos os indivíduos que participam do funcionamento do mercado. Cada indivíduo, ao comprar ou não comprar e ao vender ou não vender, dá sua contribuição para a formação dos preços de mercado. Mas, quanto mais amplo o mercado, menor o peso de cada contribuição individual. Por isso a estrutura dos preços de mercado parece, ao indivíduo, um dado ao qual ele deve ajustar sua própria conduta [...]. O processo de formação de preços é um processo social. Consuma-se pela interação de todos os membros da sociedade. Todos colaboram e cooperam, cada um no papel específico que escolheu para si mesmo no contexto da divisão do trabalho. Competindo na cooperação e cooperando na competição, estamos todos contribuindo para realizar o resultado final, qual seja, a estrutura de preços do mercado, a alocação dos fatores de produção de modo a satisfazer os diversos tipos de necessidades e a determinação da cota de cada indivíduo". MISES, Ludwig von. Ação Humana: um Tratado de Economia, trad. de Donald Stewart Jr., Rio de Janeiro: Instituto Liberal, 1990. p. 328-334. 
demais fatores externos que nelas possam influir. Quanto mais rápido é o reflexo, mais eficiente é o mercado.

Dessa forma, para que um mercado fosse completamente eficiente, todos os efetivos formadores de preço ${ }^{101}$ deveriam ter acesso a todas as informações relevantes sobre as companhias emissoras de maneira ampla, irrestrita e ao mesmo tempo, para equilibrar as regras do jogo.

No entanto, por vários motivos, nem todas as informações que poderiam afetar o preço dos valores mobiliários negociados no mercado de capitais estarão disponíveis para todos os investidores de forma equânime. Em princípio, pode-se identificar ao menos 3 (três) desses motivos. Primeiramente, é possível que as companhias emissoras de valores mobiliários falhem em divulgar certas informações, mesmo quando tal divulgação seja imposta por força da regulamentação vigente ${ }^{102}$. Além disso, a própria lei, em certos casos,

${ }^{101}$ Conforme observado por João Pedro Scalzilli e Luis Felipe Spinelli, no mercado de capitais, "o preço dos valores mobiliários é estabelecido por investidores profissionais, os quais lidam diariamente e ficam a par das informações que afetam as ações de cada sociedade mais rapidamente que qualquer outro investidor (que compra com base no preço já formado, pagando, assim, a informação - de lucro, prejuízo, descoberta de minas, de compra de concorrente, etc. - precificada no valor das ações que, muitas vezes, sequer conhece). SCALZILLI, João Pedro; SPINELLI, Luis Felipe. A Racionalidade Econômica do Combate ao Insider Trading: Assimetria de Informação e Dano ao Mercado. Revista de Direito Mercantil, Industrial, Econômico e Financeiro. São Paulo: n 147, ano XLVI, jul.-set. 2007. p. 43. No mesmo sentido, confiram-se as lições de Frank Easterbrook e Daniel Fischel: "The price of stocks traded in public markets is established by professional investors, not by amateurs. These professionals - market makers, arbitrage departments of investment banks, managers of mutual funds and pension trusts, and others - handle huge sums that they are willing to use to purchase undervalued stocks. They study the firm's profits and prospects and bid or sell accordingly. People who do this poorly will find the funds at their disposal dwindling; people who do it well will command additional sums. At any given instant, the professional traders are those who have generally been successful at assessing the worth of stock." EASTERBROOK, Frank H.; FISCHEL, R. Daniel. The economic structure of corporate law. Cambridge: Harvard University Press, 1996. p. 18.

${ }^{102}$ Neste ponto, vale ressaltar, a título de exemplo, que a análise do administrador sobre a relevância dos fatos a serem divulgados ao mercado e seu impacto sobre a negociação dos valores mobiliários da companhia perpassa por uma série de fatores que nem sempre são tão evidentes. Confira-se, neste sentido, trecho do voto do ex-diretor da CVM Pedro Oliva Marcílio de Souza, no âmbito do Processo Administrativo Sancionador n ${ }^{\circ}$ RJ2006/4776, julgado em 17.01.2007: "Dado que a decisão de publicar o fato relevante se dá, via de regra, antes que ele seja de conhecimento do público, na maioria das vezes, o administrador deve fazer juízo de valor sobre a probabilidade de que ele impacte a decisão de negociar valores mobiliários emitidos pela companhia, sem, no entanto, poder confirmar, antes da divulgação, se o fato realmente influenciará a decisão dos investidores. É, por isso, que a análise é sobre a 'potência' de impacto e não sobre o real impacto. Para o administrador, é mais fácil calcular 
permite que determinadas informações sejam mantidas em sigilo quando sua divulgação for prejudicial às companhias ${ }^{103}$. Finalmente, mesmo que a informação seja corretamente divulgada, é possível que haja certa demora até que a mesma esteja amplamente disseminada entre todos os investidores.

Assim, pode-se afirmar que a assimetria informacional, vale dizer, a desigualdade de informações detidas pelos diversos investidores no mercado de capitais, é a regra deste mercado ${ }^{104 / 105}$.

Este fenômeno da assimetria informacional, abordado de forma inovadora pelo ganhador do Prêmio Nobel de Economia, George A. Akerlof,

essa probabilidade quando o impacto do 'fato' sobre os negócios da companhia é direto. Por exemplo, a parada extraordinária de atividade em uma linha industrial da companhia é relevante se essa parada afetar significativamente as receitas, o resultado ou as demais operações da companhia. Outro exemplo, o trânsito em julgado de uma decisão judicial impondo uma perda ou um ganho para a companhia será relevante se o montante do ganho ou da perda for significativo em comparação ao patrimônio líquido da companhia. Para completar esses dois primeiros exemplos, que se referiam, respectivamente, a um fato operacional e a outro patrimonial, podemos lembrar de um fato financeiro: a obtenção de um empréstimo pode ser relevante, embora seja, usualmente, um fato do dia a dia da companhia. Digo isso, pois o empréstimo pode ser a condição suspensiva para a conclusão de uma aquisição relevante já divulgada pela companhia ou uma condição necessária ao início da construção de um projeto industrial substancial também já divulgado pela companhia. Um empréstimo pode, ainda, ser suficiente para o equacionamento da situação de liquidez, que poderia levar a companhia à falência ou a requerer recuperação judicial, e que é de conhecimento dos investidores. Em certas situações, um fato não é relevante, se olhado isoladamente, ou se forem consideradas, segregadamente, suas características quantitativas e qualitativas. Por isso, a administração deve analisar a relevância de um fato a partir do conjunto de informações de que dispõe e ponderando, de forma agregada, as informações quantitativas e qualitativas. Dessa forma, uma informação não deixará de ser relevante se a companhia dividir a sua implementação, sua divulgação ou sua análise em várias etapas, que, isoladamente, não sejam relevantes."

${ }^{103}$ A Lei n⿳ ${ }^{\circ} 6.404 / 76$ traz esta exceção em seu Art. 157, $\S 5^{\circ}$, o qual dispõe que "Os administradores poderão recusar-se a prestar a informação $\left(\S 1^{\circ}\right.$, alínea e), ou deixar de divulgá-la $\left(\S 4^{\circ}\right)$, se entenderem que sua revelação porá em risco interesse legítimo da companhia, cabendo à Comissão de Valores Mobiliários, a pedido dos administradores, de qualquer acionista, ou por iniciativa própria, decidir sobre a prestação de informação e responsabilizar os administradores, se for o caso." A Instrução CVM $\mathrm{n}^{\circ} 358 / 02$, por sua vez, prevê em seu Art. $6^{\circ}$ que "[...] os atos ou fatos relevantes podem, excepcionalmente, deixar de ser divulgados se os acionistas controladores ou os administradores entenderem que sua revelação porá em risco interesse legítimo da companhia."

${ }^{104}$ AMENDOLARA, Leslie. Fundamentos e Objetivos da Regulamentação do Sistema de Informação de Sociedades que fazem Ofertas Públicas. In: VII Congreso Argentino de Derecho Societario y III Congresso Iberoamericano de Derecho Societario y de la Empresa. La Sociedad Comercial ante El tercer milênio. Buenos Aires, p. 10.

${ }^{105}$ Dentre as principais falhas de mercado, a literatura econômica aponta o monopólio (e seus congêneres), as externalidades e a assimetria de informações. RAO, P.K.. The Economics of Transaction Costs: Theory, Methods and Applications. Grã-Bretanha, Antony Rowe, 2003. p. 43 
em sua obra “The Market for 'Lemons': Quality Uncertainty and the Market Mechanism", teria a potencialidade de gerar a chamada seleção adversa.

A expressão "lemon" é utilizada nos Estados Unidos para designar carros usados que se encontram em más condições. No mercado de carros usados, assim como no mercado de capitais, haveria, segundo referido autor, uma assimetria informacional, pois o comprador de um carro usado não saberia de antemão quais carros usados estariam em bom estado de conservação e quais seriam "lemons", informação esta detida, em um primeiro momento, somente pelo vendedor/dono do carro. O comprador de um "lemon" só viria a descobrir algo errado com o carro após adquiri-lo e ficaria insatisfeito com isso. Consequentemente, sabendo que existem "lemons" no mercado, mas sem poder distingui-los de antemão dos demais, os compradores de carros usados tenderiam a oferecer preços muito mais baixos para todos os carros usados.

Esta predisposição a oferecer preços mais baixos por um determinado produto no mercado por conta da assimetria de informações é chamada de seleção adversa. A seleção adversa no mercado de carros tenderia a "expulsar" os bons carros usados do mercado, pois os vendedores de tais carros não estariam dispostos a vendê-los pelo preço de um “lemon”. Em seu último estágio, a seleção adversa poderia causar a extinção do mercado de carros usados, uma vez que todos os carros usados em bom estado de conservação seriam retirados do mercado, e os compradores de carros usados não se interessariam por adquirir os carros usados ruins (“lemons"). ${ }^{106}$

De acordo com BLACK, tal fenômeno também poderia ser observado no mercado de capitais:

The same thing happens for securities. Investors don't know which companies are truthful and which are not truthful, so they offer lower prices for the shares of all

\footnotetext{
106 AKERLOF, George A. The Market for 'Lemons': Quality Uncertainty and the Market Mechanism. The Quarterly Journal of Economics, Vol. 84, No. 3. MIT Press: 1970. p. 489.
} 
companies. This may ensure that investors receive a fair price, on average. But now consider an honest company that reports truthfully to investors, and whose insiders will not divert some or all of the company's income stream to themselves.

Lower share prices mean that an honest company cannot receive a fair price for its shares. The honest company has an incentive to turn to other forms of financing. But lower prices will not discourage dishonest companies.

$[\ldots]$

In securities markets, adverse selection means that a higher fraction of companies are offering lemons for sale. Investors react to the lower average quality of shares by reducing still more the prices they will pay. This drives even more high-quality companies away from the stock market and exacerbates the adverse selection problem. ${ }^{107}$

Por outro lado, é ingênuo pensar que todos os investidores em um mercado possuem o mesmo nível de informação. Se assim o fosse, os mercados perderiam a razão de existir, pois haveria pouco ou nenhum incentivo para comprar ou vender os produtos nele negociados. Em última análise, o próprio incentivo para adquirir novas informações tenderia a reduzir, caso a oportunidade de lucrar em virtude de tais informações fosse eliminada. Consequentemente, sem incentivo para adquirir novas informações, os mercados perderiam sua função de proporcionar sinalizações sobre o preço dos produtos nele negociados para os diversos participantes da economia ${ }^{108}$.

Visando, porém, abrandar a assimetria de informações, legisladores dos países com mercados de capitais razoavelmente desenvolvidos, como o Brasil, passaram a adotar e a aprimorar ao longo do tempo um mecanismo de divulgação ampla, irrestrita e completa de informações, conhecido por sua expressão em inglês, "full and fair disclosure".

Com efeito, REIS e SANTOS afirmam que

\footnotetext{
107 BLACK, Bernard S. Strengthening Brazil's Securities Markets. Revista de Direito Mercantil, Industrial, Econômico e Financeiro. São Paulo: n 120, ano XLVI, jul.-set. 2007. p. 43.

108 EASTERBROOK, Frank H.; FISCHEL, R. Daniel. The economic structure of corporate law. Cambridge: Harvard University Press, 1996. p. 253-254.
} 
Ao impor deveres de prestação de informação, o legislador pretende eliminar (ou, ao menos, reduzir significativamente) essas assimetrias, consagrando o princípio da igualdade no acesso à informação - obrigando quem tem a informação a partilhá-la com quem não a tem, especialmente o público investidor. ${ }^{109}$

\subsection{O full and fair disclosure}

Como visto, o mercado de capitais é composto, basicamente, por companhias que necessitam captar recursos e por investidores que estão dispostos a oferecer estes recursos. Tal mercado, como não poderia deixar de ser, assume especial relevância na economia de um país, devendo ser regulado de forma a manter sua máxima eficiência.

É justamente neste cenário que a divulgação de informações pelas companhias emissoras de valores mobiliários junto ao público torna-se relevante. Com efeito, LAMY e BULHÕES ressaltam que a companhia aberta,

[...] além das relações (internas) com os investidores do mercado que são seus acionistas, mantém - pelo fato de participar do mercado como emissora de valores mobiliários negociados mediante oferta pública - relações com todos os investidores do mercado - inclusive os que não são titulares de valores de sua emissão, mas apenas adquirentes em potencial desses valores. ${ }^{110}$

\section{Em sentido semelhante, GARRIGUES observa que}

[...] a este direito subjetivo do acionista [direito de informação], ao qual corresponde o dever da sociedade de facilitar as informações, aparece hoje um dever mais amplo, um dever de informação ao público, precisamente a cargo daquelas sociedades que apelam à poupança popular, levando suas ações à bolsa. Em tal caso, a marcha dos negócios da sociedade não interessa somente aos acionistas, mas interessa também ao público em geral, a todos os cidadãos que podem, talvez, querer ser acionistas adquirindo ações da sociedade em questão, e que, portanto, têm direito de ser informado do que ocorre no seio da sociedade. O direito individual converteu-se em direito público. ${ }^{111}$

${ }^{109}$ REIS, Célia; SANTOS, Felipe. Divulgação de Informação. Cadernos do Mercado de Valores Mobiliários, $\mathrm{n}^{\circ}$ 28, dez/2007, CMVM, Lisboa, p. 182.

${ }^{110}$ FILHO, Alfredo Lamy; PEDREIRA, José Luiz Bulhões. A Lei das S.A. $3^{\mathrm{a}}$ ed. Rio de Janeiro: Renovar, 1997. v. 1. p. 84.

${ }^{111}$ GARRIGUES, Joaquim. Problemas Atuais das Sociedades Anônimas. Tradução, prefácio e notas do Prof. Noberto da Costa Caruso McDonald. Porto Alegre: Fabris, 1982. p. 50. 
Assim, nota-se que nas sociedades anônimas que emitem seus valores mobiliários para negociação no mercado de capitais, a divulgação de informações deve ser feita em benefício não apenas de seus acionistas, mas de toda a comunidade.

Por tudo isso, verifica-se que as normas que regulam o mercado de capitais instituem o chamado sistema de disclosure, obrigando os administradores das companhias abertas a divulgarem ao mercado de forma periódica uma série de informações, tais como demonstrações financeiras, relatórios, balanços e quaisquer outras informações reputadas como de caráter relevante.

De acordo com $\operatorname{LOSS}^{112}$, o sistema de disclosure originou-se na Inglaterra, tendo sido previsto no Companies Act de 1844. Referido diploma introduziu o princípio da divulgação obrigatória de um conteúdo mínimo de informações, através da publicação de um prospecto por parte das companhias que ofertavam valores mobiliários ao público.

Os Estados Unidos, por sua vez, econtraram em Louis D. Brandeis, juiz da Suprema Corte Americana, um dos maiores defensores do sistema de disclosure. Em seu livro, "Other People's Money", publicado em 1914, Brandeis defende que a ampla divulgação de informações seria o melhor remédio contra os problemas sociais e econômicos em geral.

Nas palavras de BRANDEIS, utilizando-se de uma figura de linguagem para se referir à política da ampla divulgação de informações, "sunlight is said to be the best of disinfectants; electric light the most efficient policeman". Por outro lado, o autor adverte que a lei não deve buscar impedir que os investidores realizem maus negócios, mas sim permitir que eles tenham acesso

\footnotetext{
${ }^{112}$ LOSS, Louis. O Papel do Governo na Proteção dos Investidores. Revista de Direito Mercantil, Industrial, Econômico e Financeiro. São Paulo, ano XXIV, n. 58, abr./jun., 1985. p. 73.
} 
amplo às informações, para que, assim, possam tomar suas decisões de investimento da forma que julgarem mais conveniente ${ }^{113}$.

De acordo com MANNE ${ }^{114}$, as ideias de Louis D. Brandeis, juntamente com Adolf A. Berle e William Z. Ripley, foram de grande influência para a criação das primeiras - e ainda em vigor - leis sobre disclosure nos Estados Unidos, refletidas no Securities Act de 1933 e no Securities Exchange Act de 1934.

Examinando o efetivo propósito da legislação de disclosure, LEÃES anota que

[...] o propósito desses comandos é o de possibilitar ao investidor comum dispor das informações necessárias para tomar decisões criteriosas com relação aos seus investimentos, e assegurar também que essas informações sejam verdadeiras. Não procura questionar a solidez do empreendimento, nem proibir que o investidor realize uma má escolha, mas apenas e tão-somente fornecer-lhe informações pertinentes para exame. Sequer tenta assegurar que as informações sejam de fato examinadas pelo investidor. A sua atuação parte do princípio, por longo tempo reconhecido no direito americano, de que a pessoa deve estar habilitada a realizar um negócio com o pleno conhecimento dos fatos, se bem que a boa ou má escolha fique reservada exclusivamente à sua vontade livre. Em suma, um mercado livre de valores exige um acesso igual para compradores e vendedores a informações materialmente relevantes, a fim de que possam tomar uma decisão criteriosa a respeito dos seus negócios. ${ }^{115}$

Assim, o sistema de disclosure pode ser entendido como a obrigação legalmente estabelecida de se promover a revelação de informações importantes a respeito das companhias abertas, de modo a permitir que os investidores, de posse das informações disponíveis, analisem o desempenho das ações e demais valores mobiliários eventualmente negociados e realizem seus investimentos da forma que melhor entenderem. Nas lições de

113 BRANDEIS, Louis D. Other People's Money. p. 34. Disponível em http://www.law.louisville.edu/library/collections/brandeis/node/191.

${ }^{114}$ MANNE, Henry G., Insider Trading and the Stock Market. New York: Free Press, 1966. p. 6.

${ }^{115}$ LEÃES, Luiz Gastão Paes de Barros. Mercado de Capitais \& “Insider Trading”. 1 a ed. São Paulo: Ed. Revista dos Tribunais, 1978. p. 26. 
EIZIRIK $^{116}$, o sistema de disclosure constitui uma "ficção jurídica", pela qual se presume que o investidor será capaz de, com base nas informações divulgadas, tomar as decisões de investimento financeiramente mais vantajosas, promovendo, ainda, uma eficiência alocacional dos recursos empregados no mercado.

No entanto, para que o sistema de disclosure atenda a seus objetivos, é preciso que as informações sejam divulgadas de forma ampla, isto é, disseminadas entre os investidores, permitindo que os mesmos tenham acesso rápido às novas informações. Daí falar-se em full disclosure (divulgação ampla e completa de informações). Além disso, as informações divulgadas devem ser verdadeiras e claras, de forma a não encobrir nenhum fato importante que deva ser divulgado. É deste pressuposto que nasce o fair disclosure, que juntamente com o primeiro, forma o princípio do full and fair disclosure ${ }^{117}$.

Dentre os principais benefícios do sistema de disclosure, a doutrina comumente aponta que (i) o mercado seria um lugar mais justo para se investir; (ii) o mercado seria um lugar menos arriscado para se investir; e (iii) os recursos seriam alocados de forma mais eficiente. ${ }^{118}$

Em seu discurso endereçado ao Investment Company Institute, a presidente da Securities and Exchange Comission, Mary L. Schapiro, ressaltou:

Markets do not work well unless investors believe they do. And investors will not believe that markets work well unless they do, in fact. That means, above all, that

\footnotetext{
${ }^{116}$ EIZIRIK, Nelson Laks. O Papel do Estado na Regulação do Mercado de Capitais. Rio de Janeiro: IBMEC, 1977. p. 120.

117 ANDREZO, Andrea Fernandes. A necessidade de maior transparência das informações $e$ orientação dos investidores para o desenvolvimento do mercado de valores mobiliários. Revista da CVM, n. 30, dez. 1999.

118 FOX, Merrit B. Securities Disclosure in a Globalizing Market: Who Should Regulate Whom? Michigan Law Review, v. 95, n. 8, Aug., 1997, p. 2533.
} 
investors must know that the information upon which they base their investment decisions is the truth, the whole truth, and nothing but the truth.

$[\ldots]$

Without that essential confidence that they have truthful and complete information upon which to base their decisions, investors will avoid our financial markets for ones that are more transparent, or they will demand risk premiums for their continued participation.

The efficient allocation of capital is simply impossible without transparency. To state the obvious, markets rely on words and numbers. They must both be true; and any new regulatory structure must preserve the integrity and independence of those charged with the responsibility for setting standards of financial disclosure. ${ }^{119}$ (grifos nossos)

Por outro lado, o sistema do disclosure não esteve - e ainda não está imune a críticas. Uma das mais duras, manifestada por William O. Douglas, professor da Universidade de Yale e ministro da Suprema Corte Americana, em artigo publicado em 1934, afirma que o Securities Act era "um pedaço de legislação do século XIX"120. Ainda de acordo com referido autor,

[...] só isso explicaria a exagerada confiança no princípio da verdade sobre títulos, como se a verdade pudesse ser revelada a quem não tenha a menor condição para compreendê-la. A coruscante luz da publicidade, em que a lei se baseia, não é o suficiente, uma vez que, aquele que necessita de orientação para fazer os seus investimentos em papéis, receberá pouco ou nenhum conforto com balanços, prospectos e demais informações revelados por força do registro de lançamento. Carecem inclusive de habilitação para assimilá-los ou julgá-los úteis. ${ }^{121 / 122}$

De fato, os investidores comuns não possuem a mesma capacidade técnica e financeira para processar as informações divulgadas pelas

119 SCHAPIRO, Mary L. Building a Stable and Efficient Financial System. Disponível em http://www.sec.gov/news/speech/2009/spch050809mls.htm.

${ }^{120}$ DOUGLAS, William; BATES, George. The Federal Securities Act of 1933. 43. Yale Law Journal, 171. Apud LOSS, Louis. O Papel do Governo na Proteção dos Investidores. Revista de Direito Mercantil, Industrial, Econômico e Financeiro. São Paulo, ano XXIV, n. 58, abr./jun., 1985. p. 78.

${ }^{121}$ Ibid. Apud. LEÃES, Luiz Gastão Paes de Barros. Mercado de Capitais \& "Insider Trading”. $1^{a}$ ed. São Paulo: Ed. Revista dos Tribunais, 1978. p. 101.

${ }^{122} \mathrm{Na}$ mesma linha, Louis Loss pondera que "o problema se reduz a saber se o investidor comum se dará ao trabalho de estudar o prospecto de uma empresa moderna, até as últimas notas de rodapé dos estudos financeiros ou, mas ainda, se estará capacitado a entender o que lê. O prospecto típico não é leitura apropriada para ser feita antes de dormir". LOSS, Louis. O Papel do Governo na Proteção dos Investidores. Revista de Direito Mercantil, Industrial, Econômico e Financeiro. São Paulo, ano XXIV, n. 58 , abr./jun., 1985. p. 76. 
companhias abertas ${ }^{123}$. Nesse sentido, chegou-se a discutir a possibilidade de uma prestação de informações em relatórios mais simples e seletivos. Entretanto, essa divulgação simplificada de informações geraria outro problema, uma vez que tenderia a mascarar e esconder dados, tendo em vista que as empresas e o mercado em que elas atuam são ambientes complexos. Dessa forma, optou-se por um sistema de disclosure mais detalhado, de forma a garantir o amplo acesso às informações por todos os investidores, embora tenha se reconhecido que tal medida tenderia a favorecer os investidores profissionais, em detrimento dos investidores não profissionais.

Outra crítica relativa ao sistema de disclosure está relacionada aos custos que esse sistema implica para as companhias abertas. Conforme observado por FOX ${ }^{124}$ e EIZIRIK ${ }^{125}$, além dos gastos com a contratação de consultorias especializadas, publicação das informações, pagamento de taxas e com a necessidade constante de atualização dos dados fornecidos, há também um custo não operacional, relativo à perda de vantagem competitiva, uma vez que os fornecedores e concorrentes teriam a chance de se beneficiar da ampla quantidade de informações financeiras da companhia.

\footnotetext{
${ }^{123}$ Neste ponto, confiram-se as críticas colocadas por Nelson Eizirik quando da promulgação da Lei n ${ }^{\circ}$ 6.404/76: "To a certain extent, the process of disclosure is based on the assumption that the rational investor, once he has information, will be able to compare the different possibilities of investment and choose the one which seems to be the most promising to him. Nevertheless, this assumption will prove to be correct only if investors really have access to information and are capable of using it in an appropriate way. In Brazil, since a market tradition does not exist, this assumption is incorrect. Information is useful, consequently, almost exclusively to financial institutions capable of analyzing it from a technical point of view and to certain institutional investors. The number of individual investors who are really trying to look for and make use of information is quite small, almost insignificant." EIZIRIK, Nelson Laks. The Role of the State in the Regulation of the Securities Markets: the Brazilian Experience. Journal of Comparative Law and Securities Regulation 1. North-Holland Publishing Company, 1978. p. 221-222.

${ }^{124}$ FOX, Merrit B. Securities Disclosure in a Globalizing Market: Who Should Regulate Whom? Michigan Law Review, v. 95, n. 8, Aug., 1997, p. 2550-52.

${ }^{125}$ CASTRO, Hélio Oliveira Portocarrero; e EIZIRIK, Nelson Laks. Regulação e Controle do Mercado de Capitais (o papel da SEC na experiência norte-americana). Rio de Janeiro, IBMEC, 1974. p. 82.
} 
Diante disso, os estudos pioneiros produzidos por STIGLER ${ }^{126}$ e BENSTON $^{127}$ procuraram demonstrar, comparando os lucros dos investidores antes e depois do Securities Act de 1933, que, na verdade, os altos custos com o sistema de disclosure incorridos pelas companhias tenderiam a reduzir o retorno dos investimentos - isto é, os custos superariam os benefícios -, uma vez que (i) a lucratividade dos títulos negociados no mercado não eram influenciados pela política de disclosure, não tendo sido constada qualquer melhoria antes e depois do Securities Act de 1933; e (ii) as exigências impostas pelo sistema de disclosure não surtiram nenhum efeito significativo no sentido positivo, tendo em vista que todas as informações relevantes para os acionistas, isto é, que excedem o custo marginal, já eram voluntariamente divulgadas pela administração das companhias.

No mesmo sentido, confiram-se as lições de ROMANO:

There is little tangible proof of the claim that corporate information is "underproduced" in the absence of mandatory disclosure, or that the benefits to investors from information that firms would not produce in the absence of mandatory disclosure actually outweigh their costs. For instance, before the enactment of the federal securities laws in the 1930s, public corporations voluntarily disclosed financial statements, typically under a stock exchange listing requirement, that contained substantially all of the information subsequently required under the federal laws. ${ }^{128}$

Apesar de todas as críticas feitas ao sistema de disclosure, fato é que o Brasil, seguindo a tendência dos países que possuem mercados de capitais mais desenvolvidos, incorporou tal sistema à sua legislação. Neste ponto, FONSECA observa que o princípio da ampla divulgação de informações “de

\footnotetext{
${ }^{126}$ STIGLER, George. Public Regulation of the Securities Markets, 37 J. Bus., 117 (1964), Apud MUNDHEIM, Robert H. Tendências do Processo de Disclosure nos Estados Unidos. Revista Brasileira de Mercado de Capitais, Rio de Janeiro, v. 1, n. 2, mai./ago. 1975. p. 182.

${ }^{127}$ BENSTON, George. Required Disclosure and the Stock Market: An Evaluation of the Securities Exchange Act of 1934. 63. Am. Econ. Rev. (1973), Apud MUNDHEIM, Robert H. Tendências do Processo de Disclosure nos Estados Unidos. Revista Brasileira de Mercado de Capitais, Rio de Janeiro, v. 1, n. 2, mai./ago. 1975. p. 183.

${ }^{128}$ ROMANO, Roberta. Empowering Investors: A Market Approach to Securities Regulation (1998). Faculty Scholarship Series. Paper 1914. p. 2373.
} 
fato já figurara, parcialmente, na legislação nacional, desde o século XIX"129. De acordo com o autor, a Lei $\mathrm{n}^{\circ} 3.150$, de 1882, já trazia disposições a respeito da obrigação de os administradores das sociedades anônimas divulgarem informações aos investidores.

Não obstante, o sistema de disclosure começou a ser efetivamente implantado no Brasil ${ }^{130}$ com o advento da Lei $\mathrm{n}^{\circ} 4.728 / 64$ e da revogada Resolução $n^{\circ}$ 88/1968 do Conselho Monetário Nacional, que exigia das companhias cujos títulos fossem negociados no mercado o compromisso de revelarem imediatamente ao público as decisões relevantes que pudessem afetar sua cotação.

No entanto, o sistema de disclosure baseado em tais normas se mostrava demasiadamente frágil, principalmente por não estabelecer com clareza o fluxo de informações que as companhias abertas estavam obrigadas a divulgar uma vez que seus valores mobiliários já estivessem em negociação no mercado. Neste sentido, vejam-se as lições de EIZIRIK:

O próprio princípio do disclosure sempre apresentou problemas na sua aplicação, talvez por se ter tentado adaptar o sistema norte-americano de divulgação de informações ao nosso contexto, reconhecidamente bastante diverso. Na realidade, possuíamos determinadas normas estabelecendo quais as informações a serem prestadas pelas companhias que recorrem ao mercado (as anteriormente denominadas Sociedades Anônimas de Capital Aberto, agora Companhias Abertas). Porém, uma observação mais acurada da legislação específica (basicamente Resoluções 88 e 214) nos mostra que havia uma concentração de exigências de informações por parte da

129 FONSECA, Herculano Borges. O Papel da Comissão de Valores Mobiliários na Economia Brasileira. Revista da CVM, v. 1, n. 1, jan./abr. 1983, p. 8.

${ }^{130}$ A adoção do sistema de disclosure pela legislação brasileira sofreu diversas críticas, além daquelas já apontadas acima. Conforme observado por Nelson Eizirik, "nos Estados Unidos, quando foram promulgadas as leis de 1933 e 1934, já havia um mercado de capitais bastante desenvolvido, embora pouco ordenado. Existia, então, uma tradição de mercado de capitais, com investidores habituados às opções de investimento que este mercado poderia oferecer. No caso brasileiro, a situação era bastante diversa, já que o mercado de capitais era pouco desenvolvido, com número reduzido de investidores". Por isso, referido autor afirma que "a adoção do princípio do disclosure no Brasil deu-se basicamente em termos formais, uma vez que mesmo a qualidade e fidedignidade das informações são discutíveis. Isto ocorre, em grande parte, por não haver uma maior pressão por parte dos usuários (via autoridade reguladora ou mesmo via tribunais) para um sistema mais acurado de informações”. EIZIRIK, Nelson Laks. O Papel do Estado na Regulação do Mercado de Capitais. Rio de Janeiro: IBMEC, 1977. p. 120. 
autoridade reguladora (então, o Banco Central) quando da emissão de valores mobiliários, da mesma forma que ocorre no sistema norte-americano. Isto ocorria a despeito do fato de nosso mercado primário, quanto à oferta pública, ter sido sempre atrofiado - desproporcional, mesmo, ao desenvolvimento dos negócios no mercado secundário, no mercado de Bolsa. Na realidade não se estabeleceu legalmente com clareza qual deveria ser o fluxo de informações prestadas pelas companhias listadas em Bolsa.

E conclui:

As informações a serem prestadas pelas companhias listadas em Bolsa eram, então, exigidas principalmente pelas Bolsas de Valores, sabidamente com pouco poder de coerção, e numa base ad hoc. ${ }^{131}$

Atualmente, os contornos fundamentais do sistema de disclosure são estabelecidos pela Lei $\mathrm{n}^{\circ} 6.404 / 76$ e Lei $\mathrm{n}^{\circ} 6.385 / 76$, ambas fortemente influenciadas pelo Securities Act de 1933 e o Securities Exchange Act de 1934.

\author{
O Art. 157 da Lei $n^{\circ} 6.404 / 76$ estabelece para os diretores ${ }^{132}$ e membros \\ do conselho de administração ${ }^{133}$ o chamado "dever de informar". Juntamente \\ com o dever de diligência e o dever de lealdade, previstos nos Arts. 153 a 156 \\ da Lei $\mathrm{n}^{\circ}$ 6.404/76, o dever de informar constitui uma das principais \\ imposições feitas pela lei aos administradores de uma companhia ${ }^{134}$.
}

\footnotetext{
${ }^{131}$ EIZIRIK, Nelson Laks; e NETTO, Horácio de Mendonça. O Privilegiamento de Informações e o Caso Petrobrás. Revista Brasileira de Mercado de Capitais, Rio de Janeiro, v. 4, n. 10, jan./abr. 1978. p. 11-12.

${ }^{132}$ No que se refere especificamente às companhias abertas, deve-se lembrar que as instruções da CVM que regulam a divulgação de informações exigem que as companhias atribuam a um diretor estatutário o cargo de diretor de relações com investidores, que terá a função de prestar as informações ao público investidor, à CVM e às bolsas de valores ou entidades de mercado de balcão organizado em que a companhia tenha seus valores mobiliários negociados. Vide, por exemplo, a Instrução $\mathrm{CVM}^{\circ}$ 480/09 e Instrução CVM n ${ }^{\circ} 358 / 02$.

${ }^{133}$ A Lei $n^{\circ} 10.303 / 01$ alterou o texto da Lei $n^{\circ}$ 6.404/76, estendendo, em certos casos, o dever de informar aos membros do conselho fiscal, conforme prevê, por exemplo, o Art. 165-A da referida lei.

134 A Lei $n^{\circ}$ 6.404/76 contempla várias outras situações que obrigam o administrador a prestar informações, tais como o Art. 62, I, que prevê a necessidade de publicação da ata da assembleia geral que deliberou sobre a emissão de debêntures, o Art. 133, referente à publicação do relatório anual, demonstrações financeiras e dos pareceres dos auditores independentes e do conselho fiscal, o Art. 224, relativo à obrigação de informar sobre as condições de incorporação, fusão ou cisão constantes do protocolo, dentre outros.
} 
Além disso, o princípio do full and fair disclosure encontra previsão em diversos dispositivos da Lei $\mathrm{n}^{\circ}$ 6.385/76, sendo os principais deles os Arts. $4^{\circ}$, VI; $8^{\circ}$, III; 19; 20 e 22, $\S 1^{\circ}$. Conforme observado por EIZIRIK,

Tais normas delegam à Comissão de Valores Mobiliários o poder de fiscalizar a veiculação de informações relativas ao mercado de capitais, fixando sua competência normativa para regular, dentre outras matérias, a natureza e a periodicidade das informações prestadas pelas companhias abertas; os relatórios da administração das companhias; os padrões de contabilidade e pareceres dos auditores independentes; a divulgação de deliberação da assembleia geral ou dos órgãos da administração, etc. ${ }^{135}$

Em vista de tais poderes, a CVM editou a Instrução CVM n 31/84, que tratava da divulgação e do uso de informações sobre o ato ou fato relevante relativo às companhias abertas. Tal regulamentação foi revogada pela Instrução $\mathrm{CVM} \mathrm{n}^{\circ} 358 / 02$, que atualmente disciplina a matéria ${ }^{136}$.

Mas, afinal, qual a relação entre o princípio do full and fair disclosure e as normas de combate ao insider trading? Neste ponto, confiram-se as lições de LEÃES:

[...] o princípio do disclosure não se esgota apenas com a prestação de informações: é preciso que paralelamente medidas sejam tomadas para que todos os investidores potenciais tenham, ao mesmo tempo, acesso às novas informações, impedindo-se assim que os administradores, altos empregados e acionistas controladores, utilizemse em proveito próprio de informações colhidas em primeira mão por força da posição que ocupam. A repressão ao insider tradig é, destarte, corolário natural da adoção do princípio do disclosure na regulação do mercado de valores. ${ }^{137 / 138}$

${ }^{135}$ EIZIRIK, Nelson Laks; GAAL, Ariádna B.; PARENTE, Flávia; HENRIQUES, Marcus de Freitas. Mercado de Capitais - regime jurídico. 2. ed. (revisada e atualizada). Rio de Janeiro: Renovar, 2008. p. 466.

${ }^{136}$ Dentre outras questões, a Instrução CVM n ${ }^{\circ}$ 358/02 estabeleceu a noção de ato ou fato relevante. Tendo em vista a importância deste conceito para o presente trabalho e sua íntima relação com as normas de combate ao insider trading, dedicar-se-á um tópico exclusivo a este tema no Capítulo 4.

${ }^{137}$ LEÃES, Luiz Gastão Paes de Barros. Mercado de Capitais \& “Insider Trading”. 1ª ed. São Paulo: Ed. Revista dos Tribunais, 1978. p. 182-183.

${ }^{138}$ Em sentido semelhante, Nelson Eizirik aponta que "a ampla política de divulgação de informações completa-se, porém, com um segundo princípio, dela decorrente: as informações devem ser tornadas acessíveis a todos ao mesmo tempo, sem que qualquer pessoa possa utilizá-las, em proveito próprio ou de outrem, antes de sua divulgação. É com base em tal noção que se procura combater, então, o privilegiamento de informações, conhecido nos EUA e Inglaterra como insider trading." EIZIRIK, Nelson Laks; e NETTO, Horácio de Mendonça. O Privilegiamento de Informações e o Caso Petrobrás. Revista Brasileira de Mercado de Capitais, Rio de Janeiro, v. 4, n. 10, jan./abr. 1978. p. 8. 
Assim, conclui PARENTE, "o dever de informar configura-se como parte complementar e indispensável na repressão ao uso da informação privilegiada" ${ }^{\prime 39}$.

Feitas estas considerações sobre o princípio do full and fair disclosure e compreendida sua importância para as discussões acerca do insider trading, será analisado, a seguir, o aparato legislativo, doutrinário e jurisprudencial que se desenhou em torno da problemática envolvida na negociação de valores mobiliários de posse de informações privilegiadas, tema central do presente trabalho.

${ }^{139}$ PARENTE, Norma. Aspectos Jurídicos do "Insider Trading”. CVM. Superintendência Jurídica, Junho de 1978. p. 8. 


\section{CAPÍTULO 4 - O TRATAMENTO LEGAL DO INSIDER TRADING NO BRASIL}

Conforme observado por PARENTE, o principal objetivo das normas de combate ao insider trading é

[...] evitar que pessoas, direta ou indiretamente relacionadas com a empresa, possam auferir ganhos patrimoniais extraordinários, através da prevalência do conhecimento de atos ou fatos importantes, e reservados, sobre mutações essenciais na vida da companhia. ${ }^{140}$

O combate ao insider trading, aponta EIZIRIK, "é realizado mediante normas preventivas e repressivas" ${ }^{\prime 141}$. As normas preventivas estão intimamente ligadas à promoção do sistema de disclosure, já referido no item 3.4 acima, de forma a assegurar a necessária visibilidade às operações realizadas no mercado de capitais, impondo também aos insiders a obrigação de informar as operações por eles realizadas. As normas repressivas, por seu turno, vedam o uso de informações privilegiadas, cominando sanções de natureza civil, administrativa e penal.

Tendo em vista que as normas que tratam do insider trading nas diferentes esferas obedecem a princípios e apresentam redações similares, sua análise será realizada em conjunto.

Feitas estas considerações preliminares, essenciais à boa compreensão da nossa legislação, serão enumerados e descritos, na sequência, os principais dispositivos legais que regulam a utilização de informações privilegiadas, visando oferecer ao leitor um guia legislativo sobre o tema.

\footnotetext{
140 PARENTE, Norma. Aspectos Jurídicos do "Insider Trading”. CVM. Superintendência Jurídica, Junho de 1978. p. 8.

${ }^{141}$ EIZIRIK, Nelson Laks; GAAL, Ariádna B.; PARENTE, Flávia; HENRIQUES, Marcus de Freitas. Mercado de Capitais - regime jurídico. 2. ed. (revisada e atualizada). Rio de Janeiro: Renovar, 2008. p. 538.
} 


\subsection{Evolução legislativa: do Decreto $n^{\circ} 2.627 / 40$ à Lei $n^{\circ} 6.404 / 76$}

No período compreendido entre 1940 e 1976, as companhias abertas eram regidas, no Brasil, pelo Decreto-Lei n ${ }^{\circ}$ 2.627/40, do qual, atualmente, só estão em vigor os Arts. 59 a 73. Dentre tais dispositivos, apenas o Art. $70^{142}$ faz referência à prestação de informações por parte da companhia. No entanto, referido artigo exige apenas que companhias estrangeiras adotem determinadas medidas relacionadas à divulgação de informações, não alcançando, por conseguinte, nem mesmo o teor das normas preventivas de combate ao insider trading. ${ }^{143}$

Posteriormente, a Lei $\mathrm{n}^{\circ} 4.728 / 65$ trouxe o dispositivo considerado pela doutrina $^{144}$ como a primeira regra sobre o insider trading no Brasil, ao atribuir ao Banco Central a competência para "fiscalizar a utilização de informações não divulgadas ao público em benefício próprio ou de terceiros, por acionistas ou pessoas que, por força de cargos que exerçam, a elas tenham acesso" ${ }^{\text {145 }}$.

No entanto, tal disposição meramente programática não se mostrou suficiente para refrear o uso de informações privilegiadas no mercado de capitais, conforme observado por COMPARATO:

As insuficiências desse dispositivo são manifestas.

\footnotetext{
142 “Art. 70. As sociedades anônimas estrangeiras devem, sob pena de ser-lhes cassada a autorização para funcionar no país, reproduzir no órgão oficial da União, e do Estado, si for caso (art. 173), as publicações que, segundo a sua lei nacional ou de origem, sejam obrigadas a fazer relativamente ao balanço, conta de lucros e perdas e atos de sua administração."

${ }^{143}$ Modesto Carvalhosa observa que os preceitos contidos na atual legislação brasileira de combate ao insider trading não encontravam correspondente no Decreto-Lei ${ }^{\circ} 2.627 / 40$, pois tais preceitos são frutos da elaboração da common law, enquanto referido Decreto-Lei filiava-se à tradição do direito continental europeu. CARVALHOSA, Modesto. Comentários à Lei das Sociedades Anônimas. 4. ed. São Paulo. Saraiva, 2009. vol. 3, p. 292.

${ }^{144}$ Neste sentido, veja-se, dentre outros, LEÃES, Luiz Gastão Paes de Barros. Mercado de Capitais \& "Insider Trading". $1^{\text {a }}$ ed. São Paulo: Ed. Revista dos Tribunais, 1978. p. 183.; CARVALHOSA, Modesto. Comentários à Lei das Sociedades Anônimas. 4. ed. São Paulo. Saraiva, 2009. vol. 3, p. 292; e COMPARATO, Fábio Konder. Insider Trading: Sugestões para uma moralização do nosso mercado de capitais. Revista de Direito Mercantil, Industrial, Econômico e Financeiro. São Paulo, ano X, n. 2, 1971.p. 46.

${ }^{145}$ Art. $3^{\circ}, \mathrm{X}$ da Lei ${ }^{\circ} 4.728 / 65$.
} 
Em primeiro lugar, a fiscalização supõe a existência de normas particulares de disciplina da matéria, cujo cumprimento possa ser fiscalizado. Ora, tais normas não foram definidas, e é duvidoso que sua formulação compita ao Conselho Monetário, ou ao Banco Central, no estado atual da nossa legislação. A Lei de Mercado de Capitais [Lei $\mathrm{n}^{\circ} 4.728 / 65$ ] está longe de ser clara a esse respeito.

\section{$[\ldots]$}

Além disso, a norma do art. $3^{\circ}$, n. X, da Lei de Mercado de Capitais, falando em fiscalização da insider trading pelo Banco Central, supõe também um sistema adequado de sanções para essas manifestações. Ora, neste ponto só encontramos a disposição do art. $4^{\circ}, \S 6^{\circ}$, que manda aplicar "aos infratores do disposto na presente Lei as penalidades previstas no Capítulo V da Lei . 4.595, de 31.12.1964”, quando é manifesta a inadequação do sistema punitivo da Lei Bancária ao problema em questão. ${ }^{146}$

Somam-se a essas críticas as manifestadas por LEÃES:

A lei, no entanto, não fornece os parâmetros ou as condições para o exercício dessa fiscalização de polícia, dificuldade essa que se soma a definição de contornos pouco precisos do fato delituoso, sem detalhar sequer quais os atos que podem configurar o privilegiamento de informações. Ademais, de nada adianta incriminar e sancionar condutas genéricas, com sanções de polícia diversas, nem sempre adequadas às hipóteses delituosas, conforme a remissão feita pelo art. $4^{\circ}, \S 6^{\circ}$, da Lei 4.728 ao capítulo V da Lei 4.595, de 31.12.1964. ${ }^{147}$

Em 1966, a Resolução n 39/66 do Banco Central, que disciplinou a constituição, organização e o funcionamento das bolsas de valores, incriminou e sancionou em seu Art. 89, II, a manipulação fraudulenta de preço, definida como

[...] a publicação ou divulgação de matéria relativa a títulos e valores mobiliários, seu mercado, cotação e perspectivas, ou sobre a respectiva sociedade emitente, cujo autor ou veiculador: [...] II - seja direta ou indiretamente ligado à sociedade, como diretor, conselheiro, empregado, prestador de serviços ou acionista que influa em seu controle.

No entanto, observa LEÃES, "não se pode entrever aí proibição ao insider trading, que é um fenômeno de nondisclosure, e nem se confunde com

\footnotetext{
146 COMPARATO, Fábio Konder. Insider Trading: Sugestões para uma moralização do nosso mercado de capitais. Revista de Direito Mercantil, Industrial, Econômico e Financeiro. São Paulo, ano X, n. 2, 1971. p. 46.

${ }^{147}$ LEÃES, Luiz Gastão Paes de Barros. Mercado de Capitais \& “Insider Trading”. 1ª ed. São Paulo: Ed. Revista dos Tribunais, 1978. p. 183.
} 
a manipulação de preços, pois o comportamento daquele que se utiliza de informações sigilosas não influi no valor dos títulos negociados." $148 / 149$

Ainda na década de 60, o Banco Central, por meio da Resolução ${ }^{\circ}$ $88 / 68$, que instituiu o regulamento disciplinador do registro das pessoas jurídicas emissoras de valores mobiliários negociáveis em bolsa, bem como o registro das respectivas emissões, buscou complementar o comando genérico contido na Lei $n^{\circ} 4.728 / 65$, ao exigir das companhias

[...] compromisso formal de revelarem, prontamente, ao público, as decisões tomadas pela Diretoria e pela Assembleia Geral com relação a dividendos, os direitos de subscrição ou outros relevantes que possam afetar os preços dos títulos ou valores mobiliários de sua emissão, ou influenciar as decisões dos investidores. ${ }^{150}$

Apesar da crítica de $\operatorname{LEÃES}^{151}$, segundo a qual este dispositivo não trouxe "nenhuma alusão à proibição de utilização dessas informações, antes de reveladas ao público, pelos insiders, esgotando-se nesse comando de disclosure", PROENÇA ${ }^{152}$ ressalta que "pode-se enxergar, nela, o nascedouro, no campo legislativo, do hoje denominado "fato relevante".

\footnotetext{
148 Ibid. p. 184. Neste ponto, cabe apenas esclarecer que, dependendo do volume da operação e de outras condições de mercado, a negociação com base em informações sigilosas é, sim, capaz de afetar a cotação dos valores mobiliários. Por outro lado, a prática do insider trading, em si, não visa manipular ou causar modificações artificiais nas cotações de tais títulos.

${ }^{149}$ Em sentido semelhante, Fábio Konder Comparato anota que "a manipulação não consiste no aproveitamento de informações ainda não reveladas ao público, mas, ao contrário, na criação de situações artificiais de demanda, oferta e preço, em proveito do manipulador. Este não procede, pois à semelhança do 'insider', revelando informações secretas ou delas se aproveitando; mas, antes, divulgando informações incorretas." COMPARATO, Fábio Konder. A regra de sigilo nas ofertas públicas de aquisição de ações. In Direito Empresarial: Estudos e Pareceres. Rio de Janeiro: Saraiva, 1990. p. 349.

${ }^{150}$ Item VI, alínea "d” do Anexo da Resolução n 88/68.

${ }^{151}$ LEÃES, Luiz Gastão Paes de Barros. Mercado de Capitais \& “Insider Trading”. 1ª ed. São Paulo: Ed. Revista dos Tribunais, 1978. p. 184.

${ }^{152}$ PROENÇA, José Marcelo Martins. Insider Trading. Regime jurídico do uso de informações privilegiadas no mercado de capitais. São Paulo: Ed. Quartier Latin, 2005. p. 276.
} 


\title{
4.2. A Lei $n^{\circ} 6.404 / 76$ e suas alterações
}

\author{
Conforme observado por MUSSNICH,
}

Até o ano de 1976, as companhias no Brasil eram regidas pelo Decreto-lei 2.627 de 26.9.1940, que ao tempo de sua promulgação já era considerada Lei "Velha".

O sancionamento do Presidente da República em 15.12.1976 da Lei 6.404, não foi apenas o reconhecimento desta obsolescência legislativa, mas também representou a vitória de um movimento legal que visava implantar no Brasil um sistema jurídico que possibilitasse às empresas desenvolverem economias de escala. ${ }^{153}$

\section{Com efeito, CASTELLAR observa que}

Será somente com o advento da Lei $n^{\circ}$ 6.404/76 que se encontrará preceito legal sistematicamente contextualizado, de modo a estabelecer os deveres e responsabilidade civil e administrativa dos insider (detentores das informações privilegiadas), e que inequivocamente inspirou o tipo penal $\left[\ldots . .{ }^{154}\right.$

Assim, a Lei $n^{\circ}$ 6.404/76, mesmo em sua redação original, representou uma grande inovação no combate ao insider trading, trazendo as primeiras normas efetivamente repressivas, além das normas de caráter preventivo, conforme classificação acima abordada.

\subsubsection{Comandos de caráter preventivo: Arts. 116-A, 157 e 260}

O principal dispositivo da Lei $\mathrm{n}^{\circ} 6.404 / 76$ de natureza preventiva à prática do insider trading é o Art. 157, que, inspirado no "duty of disclosure" do direito societário norte-americano, instituiu o "dever de informar" para os administradores das companhias abertas:

Art. 157. O administrador de companhia aberta deve declarar, ao firmar o termo de posse, o número de ações, bônus de subscrição, opções de compra de ações e debêntures conversíveis em ações, de emissão da companhia e de sociedades controladas ou do mesmo grupo, de que seja titular.

\footnotetext{
153 MUSSNICH, Francisco Antunes Maciel. A utilização desleal de informações privilegiadas "insider trading" - no Brasil e nos Estados Unidos. Revista de Direito Mercantil, Industrial, Econômico e Financeiro. São Paulo: n 34, ano XVIII, abr.-jun. 1979. p. 43.

${ }^{154}$ CASTELLAR, João Carlos. Insider Trading e os Novos Crimes Corporativos. Rio de Janeiro: Ed. Lumen Juris, 2008. p. 91.
} 
$\S 1^{\circ} \mathrm{O}$ administrador de companhia aberta é obrigado a revelar à assembléia-geral ordinária, a pedido de acionistas que representem $5 \%$ (cinco por cento) ou mais do capital social:

a) o número dos valores mobiliários de emissão da companhia ou de sociedades controladas, ou do mesmo grupo, que tiver adquirido ou alienado, diretamente ou através de outras pessoas, no exercício anterior;

b) as opções de compra de ações que tiver contratado ou exercido no exercício anterior;

c) os benefícios ou vantagens, indiretas ou complementares, que tenha recebido ou esteja recebendo da companhia e de sociedades coligadas, controladas ou do mesmo grupo;

d) as condições dos contratos de trabalho que tenham sido firmados pela companhia com os diretores e empregados de alto nível;

e) quaisquer atos ou fatos relevantes nas atividades da companhia.

$\S 2^{\circ}$ Os esclarecimentos prestados pelo administrador poderão, a pedido de qualquer acionista, ser reduzidos a escrito, autenticados pela mesa da assembléia, e fornecidos por cópia aos solicitantes.

$\S 3^{\circ}$ A revelação dos atos ou fatos de que trata este artigo só poderá ser utilizada no legítimo interesse da companhia ou do acionista, respondendo os solicitantes pelos abusos que praticarem.

$\S 4^{\circ}$ Os administradores da companhia aberta são obrigados a comunicar imediatamente à bolsa de valores e a divulgar pela imprensa qualquer deliberação da assembléia-geral ou dos órgãos de administração da companhia, ou fato relevante ocorrido nos seus negócios, que possa influir, de modo ponderável, na decisão dos investidores do mercado de vender ou comprar valores mobiliários emitidos pela companhia.

$\S 5^{\circ}$ Os administradores poderão recusar-se a prestar a informação ( $§ 1^{\circ}$, alínea e), ou deixar de divulgá-la $\left(\S 4^{\circ}\right)$, se entenderem que sua revelação porá em risco interesse legítimo da companhia, cabendo à Comissão de Valores Mobiliários, a pedido dos administradores, de qualquer acionista, ou por iniciativa própria, decidir sobre a prestação de informação e responsabilizar os administradores, se for o caso.

$\S 6^{\circ}$ Os administradores da companhia aberta deverão informar imediatamente, nos termos e na forma determinados pela Comissão de Valores Mobiliários, a esta e às bolsas de valores ou entidades do mercado de balcão organizado nas quais os valores mobiliários de emissão da companhia estejam admitidos à negociação, as modificações em suas posições acionárias na companhia.

Deste dispositivo, dois aspectos demandam comentários mais acurados enquanto medidas preventivas ao uso de informações privilegiadas. Em primeiro lugar, o caput do Art. 157, ao exigir que os administradores da 
companhia aberta revelem a quantidade de qualquer espécie de ativo emitido pela companhia de que sejam titulares, constitui um primeiro elemento para permitir a investigação de uma possível prática de insider trading.

No entanto, antes da inserção do parágrafo $6^{\circ}$, feito pela Lei 10.303/2001, a regra contida no caput do Art. 157 era considerada praticamente inócua, pois refletia apenas uma posição estática da carteira de valores mobiliários detida pelos administradores. ${ }^{155}$ Após a inserção do referido parágrafo, os administradores da companhia aberta passaram a estar obrigados a informar imediatamente à CVM e às bolsas de valores e entidades do mercado de balcão organizado quaisquer modificações em suas posições acionárias $^{156}$. Tal obrigação permite um monitoramento permanente da movimentação dos administradores no mercado de valores mobiliários, notadamente através de negociações em bolsa, com ações e outros valores mobiliários de emissão da companhia que administram.

O segundo aspecto do Art. 157 da Lei ${ }^{\circ}$ 6.404/76 que merece destaque diz respeito ao disposto no parágrafo $4^{\circ}$ deste dispositivo, que obriga os administradores da companhia aberta a divulgarem imediatamente ao mercado qualquer fato relevante ocorrido nos negócios da companhia que possa influir a decisão dos investidores de comprar ou vender valores mobiliários de sua emissão. Com isso, busca a lei, dentre outros fins, prevenir que os

${ }^{155}$ EIZIRIK, Nelson Laks; GAAL, Ariádna B.; PARENTE, Flávia; HENRIQUES, Marcus de Freitas. Mercado de Capitais - regime jurídico. 2. ed. (revisada e atualizada). Rio de Janeiro: Renovar, 2008. p. 463.

${ }^{156}$ Cabe neste ponto apenas observar que segundo o caput do Art. 157 da Lei $\mathrm{n}^{\circ}$ 6.404/76, o administrador deve informar sua posição não somente em ações da companhia, mas também em bônus de subscrição, opções de compra e debêntures conversíveis em ações da companhia. $\mathrm{O}$ parágrafo $6^{\circ}$ do referido artigo, por sua vez, exige que o administrador informe apenas as modificações em sua posição acionária, não sendo necessário, em uma leitura literal, informar alterações referentes à situação de opões de compra de ações e debêntures conversíveis em ações, por exemplo. No entanto, sustentando que ambos os dispositivos devem ser lidos de forma sistemática, Modesto Carvalhosa e Nelson Eizirik observam que "em consequência, deverão os administradores declarar não somente as mudanças em suas posições acionárias, mas também em suas posições quanto aos demais títulos mencionados no caput do art. 157." CARVALHOSA, Modesto; EIZIRIK, Nelson Laks. A Nova Lei das S.A. São Paulo: Saraiva, 2002. p. 324. 
administradores atrasem a divulgação de informações relevantes ao mercado visando delas se aproveitar mediante a negociação de valores mobiliários que ainda não refletem em seu preço o impacto de tais informações.

Conforme enfatizado pelo Juiz Leahy, de Delaware, no famoso caso Speed v. Transamerica Corp., de 1951:

O dever de informar promana de necessidade de impedir que o insider se aproveite da posição que ocupa para tirar vantagens indevidas em detrimento dos acionistas minoritários desinformados. É uma tentativa de prover o acionista com um certo grau de igualdade em termos de poder de barganha, de modo a lhe fornecer condições para o exercício de um julgamento criterioso, em toda transação. ${ }^{157}$

Além do Art. 157, a Lei n 6.404/76 traz, ainda, pelo menos outros dois dispositivos que também cumprem um caráter preventivo no combate ao insider trading, quais sejam os Arts. 116-A e 260.

O Art. 116-A foi incluído na Lei $\mathrm{n}^{\circ}$ 6.404/76 pela Lei $\mathrm{n}^{\circ}$ 10.303/01, seguindo a tendência de aprimorar as ferramentas de combate à utilização de informações privilegiadas. Assim, à semelhança do que dispõe o parágrafo $4^{\circ}$ do Art. 157, o Art. 116-A prevê o seguinte:

Art. 116-A. O acionista controlador da companhia aberta e os acionistas, ou grupo de acionistas, que elegerem membro do conselho de administração ou membro do conselho fiscal, deverão informar imediatamente as modificações em sua posição acionária na companhia à Comissão de Valores Mobiliários e às Bolsas de Valores ou entidades do mercado de balcão organizado nas quais os valores mobiliários de emissão da companhia estejam admitidos à negociação, nas condições e na forma determinadas pela Comissão de Valores Mobiliários.

Com isso, buscou o legislador abranger o dever de divulgar as movimentações na posição acionária ao acionista controlador e ao grupo de acionistas que elegerem membros do conselho de administração ou fiscal. A razão desta norma está no fato de que tanto o acionista controlador como os demais acionistas que elegem membros do conselho de administração

\footnotetext{
${ }^{157}$ LEÃES, Luiz Gastão Paes de Barros. Mercado de Capitais \& “Insider Trading”. 1 1 ed. São Paulo:
} Ed. Revista dos Tribunais, 1978. p. 185. 
encontram-se, em tese, mais próximos da companhia, estando, portanto, mais suscetíveis ao conhecimento de informações sensíveis sobre a sociedade.

Assim, visando evitar que por força de sua posição, tais acionistas se aproveitassem das informações sigilosas eventualmente recebidas para negociar com valores mobiliários antes de sua divulgação ao público, a Lei passou a exigir que tais acionistas informem sua posição acionária e respectivas modificações à CVM e à bolsa de valores, possibilitando que tais órgãos exerçam um monitoramento de possíveis movimentações atípicas com ações de emissão da companhia em questão por parte de tais pessoas.

O Art. 260 da Lei ${ }^{\circ}$ 6.404/76 também figura como elemento preventivo da prática de insider trading, prevendo que "até a publicação da oferta, o ofertante, a instituição financeira intermediária e a Comissão de Valores Mobiliários devem manter sigilo sobre a oferta projetada, respondendo o infrator pelos danos que causar."

Sobre o papel deste comando no combate ao uso de informações privilegiadas, confiram-se os ensinamentos de COMPARATO:

A norma em questão [Art. 260] refere-se, obviamente, à prática do insider trading.

Se a oferta pública aí prevista não é a consequência necessária de um fato notório, obrigatoriamente levado ao conhecimento da Comissão de Valores Mobiliários, e se o conteúdo dessa oferta é indeterminado, ao contrário do que sucede nas hipóteses dos arts. 254 e 255 , então é de primordial importância que os "iniciados" não se aproveitem de informes reservados, para benefício próprio ou de outrem, adquirindo antecipadamente a bom preço o que pretendem revender muito mais caro no curso da oferta pública. De resto, como se viu acima, a preocupação maior, objetivada pelas regulações estrangeiras nessa matéria, é justamente com as atividades dolosas dos insiders. ${ }^{158}$

${ }^{158}$ COMPARATO, Fábio Konder. A regra de sigilo nas ofertas públicas de aquisição de ações. In Direito Empresarial: Estudos e Pareceres. Rio de Janeiro: Saraiva, 1990. p. 350. 


\subsubsection{Comando de caráter repressivo: Art. 155}

Representado o primeiro dispositivo verdadeiramente repressivo contra o insider trading ${ }^{159}$, o Art. 155 da Lei $n^{\circ}$ 6.404/76 introduziu na legislação societária brasileira o chamado standard of loyalty do direito norte-americano, conhecido no Brasil como "dever de lealdade". Eis o que dispõe mencionado artigo:

Art. 155. O administrador deve servir com lealdade à companhia e manter reserva sobre os seus negócios, sendo-lhe vedado:

I - usar, em benefício próprio ou de outrem, com ou sem prejuízo para a companhia, as oportunidades comerciais de que tenha conhecimento em razão do exercício de seu cargo;

II - omitir-se no exercício ou proteção de direitos da companhia ou, visando à obtenção de vantagens, para si ou para outrem, deixar de aproveitar oportunidades de negócio de interesse da companhia;

III - adquirir, para revender com lucro, bem ou direito que sabe necessário à companhia, ou que esta tencione adquirir.

$\S 1^{\circ}$ Cumpre, ademais, ao administrador de companhia aberta, guardar sigilo sobre qualquer informação que ainda não tenha sido divulgada para conhecimento do mercado, obtida em razão do cargo e capaz de influir de modo ponderável na cotação de valores mobiliários, sendo-lhe vedado valer-se da informação para obter, para si ou para outrem, vantagem mediante compra ou venda de valores mobiliários.

$\S 2^{\circ} \mathrm{O}$ administrador deve zelar para que a violação do disposto no $\S 1^{\circ}$ não possa ocorrer através de subordinados ou terceiros de sua confiança.

$\S 3^{\circ}$ A pessoa prejudicada em compra e venda de valores mobiliários, contratada com infração do disposto nos $\S \S 1^{\circ}$ e $2^{\circ}$, tem direito de haver do infrator indenização por perdas e danos, a menos que ao contratar já conhecesse a informação.

§4ํㅡ É vedada a utilização de informação relevante ainda não divulgada, por qualquer pessoa que a ela tenha tido acesso, com a finalidade de auferir vantagem, para si ou para outrem, no mercado de valores mobiliários.

\footnotetext{
159 Corroborando esta afirmação, Nelson Eizirik e Horácio de Mendonça Netto apontam que "no Brasil, até o advento da nova Lei das Sociedades Anônimas (Lei 6.404, de 15/12/76), não estava estabelecido com clareza um sistema legal de repressão ao privilegiamento de informações". EIZIRIK, Nelson Laks; e NETTO, Horácio de Mendonça. O Privilegiamento de Informações e o Caso Petrobrás. Revista Brasileira de Mercado de Capitais, Rio de Janeiro, v. 4, n. 10, jan./abr. 1978. p. 11.
} 
Além das vedações elencadas nos incisos I a III, que não estão diretamente relacionadas ao combate ao insider trading, o parágrafo $1^{\circ}$ do Art. 155 impõe aos administradores o dever de sigilo, vedando, ainda, a utilização de informações ainda não divulgadas para obter, para si ou para outrem, vantagem mediante a compra ou venda de valores mobiliários.

\section{Conforme observado por SAMPAIO CAMPOS,}

A companhia, no desenvolvimento de seus negócios, gera e adquire diversas informações que merecem tratamento confidencial. São informações que lhe pertencem e que, portanto, merecem proteção legal. Decorre daí, como desdobramento lógico do dever de lealdade, que os administradores devem guardar reserva sobre as informações que envolvam a companhia e que tenham sido obtidas durante o exercício do cargo. ${ }^{160}$

De acordo com EIZIRIK ${ }^{161}$, o dever de sigilo comporta dois aspectos, sendo o primeiro deles relacionado à manutenção de reserva sobre os negócios da companhia, principalmente quando a divulgação da informação ao público possa causar prejuízos à sociedade, e o segundo relativo à vedação ao insider trading.

Ainda segundo referido autor, o Art. $155, \S 1^{\circ}$ da Lei $\mathrm{n}^{\circ}$ 6.404/76 deve ser interpretado conjuntamente com o disposto no parágrafo $4^{\circ}$ do Art. 157:

Da leitura conjunta destes dois dispositivos, resulta claro que a Lei seguiu o padrão normativo do direito norte-americano, referente ao dever do "insider" de divulgar ou abster-se de utilizar a informação em proveito próprio ("disclose or refrain from trading"). Assim, estando o administrador na posse de informação relevante, sua obrigação fundamental é revela-la ao público, em razão do princípio fundamental do "disclosure". Porém, enquanto tal informação não for divulgada ao público, ele fica proibido de negociar com valores mobiliários de emissão da companhia. ${ }^{162}$

160 CAMPOS, Luiz Antonio de Sampaio. Conselho de Administração e Diretoria. Deveres e Responsabilidades. In FILHO, Alfredo Lamy; PEDREIRA, José Luiz Bulhões. Direito das Companhias. Rio de Janeiro: Forense, 2009. p. 1.143.

${ }^{161}$ EIZIRIK, Nelson Laks; GAAL, Ariádna B.; PARENTE, Flávia; HENRIQUES, Marcus de Freitas. Mercado de Capitais - regime jurídico. 2. ed. (revisada e atualizada). Rio de Janeiro: Renovar, 2008. p. 447.

162 Ibid. p. 448. 
Cabe observar que no período transcorrido entre a promulgação da Lei $\mathrm{n}^{\circ} 6.404 / 76$ e a sua reforma promovida pela Lei $\mathrm{n}^{\circ} 10.303 / 01$, o parágrafo $1^{\circ}$ do Art. 155 era único dispositivo legal que vedava expressamente a utilização de informações privilegiadas. Tal fato ensejou críticas por grande parte da doutrina, uma vez que referido dispositivo permitia a imputação do insider trading apenas aos administradores, seus subordinados e terceiros de sua confiança $^{163}$.

Além disso, deve-se ressaltar que consoante o disposto no Art. 145 da Lei ${ }^{\circ}$ 6.404/76, "as normas relativas a requisitos, impedimentos, investidura, remuneração, deveres e responsabilidade dos administradores aplicam-se a conselheiros e diretores", de forma que tanto membros do conselho de administração quanto diretores estão sujeitos às proibições relativas ao uso de informações privilegiadas.

Além disso, o Art. 160 da Lei ${ }^{\circ}$ 6.404/76 estende as responsabilidades e vedações aplicáveis aos administradores "aos membros de quaisquer órgãos, criados pelo estatuto, com funções técnicas ou destinados a aconselhar os administradores", o que também é feito pelo Art. 165, ao prever que os "membros do conselho fiscal têm os mesmos deveres dos administradores de que tratam os arts. 153 a 156 e respondem pelos danos resultantes de omissão no cumprimento de seus deveres e de atos praticados com culpa ou dolo, ou com violação da lei ou do estatuto."

Assim, por força de tais dispositivos, estariam abrangidos pela vedação contida no parágrafo $1^{\circ}$ do Art. 155 (i) membros do conselho de administração;

\footnotetext{
${ }^{163}$ Tendo em vista que desde 2001 tal problema encontra-se definitivamente superado, este trabalho não abordará as discussões doutrinárias havidas durante o período citado e as formas encontradas para responsabilizar terceiros não ligados à companhia pela prática de insider trading. Para tais discussões, veja-se EIZIRIK, Nelson Laks. Insider Trading e a Responsabilidade de Administrador de Companhia Aberta. Revista de Direito Mercantil, Industrial, Econômico e Financeiro. São Paulo: n 50, ano XXII, abr.-jun. 1983.
} 
(ii) membros da diretoria; (iii) membros de quaisquer órgãos criados pelo estatuto, com funções técnicas ou destinados a aconselhar os administradores; e (iv) membros do conselho fiscal.

Com a reforma da Lei $\mathrm{n}^{\circ}$ 6.404/76 ocorrida em 2001, o parágrafo $4^{\circ}$ do Art. 155 também passou a vedar a utilização de informação relevante, ainda não divulgada, por qualquer pessoa que a ela tenha tido acesso, com a finalidade de auferir vantagem, para si ou para outrem, no mercado de valores mobiliários. Não obstante as discussões envolvendo o limite da expressão "qualquer pessoa" e os conceitos de "tipper" e "tippee", objeto de estudo do próximo capítulo, fato é que o parágrafo $4^{\circ}$ do Art. 155 ampliou o rol de pessoas que podem ser responsabilizadas pelo uso de informações privilegiadas, abarcando pessoas não diretamente ligadas à companhia.

\subsection{A Lei $n^{\circ} 6.385 / 76$}

Conforme já referido anteriormente, após a reforma promovida na Lei $\mathrm{n}^{\circ}$ 6.385/76 pela Lei $\mathrm{n}^{\circ} 10.303 / 01$, passou a constar como objetivo a pautar a atuação da CVM (Art. 4, IV, “c"), "proteger os titulares de valores mobiliários e os investidores do mercado contra [...] o uso de informação relevante não divulgada no mercado de valores mobiliários".

Assim, apesar de o combate ao insider trading por meio de normas emanadas pela CVM ter se iniciado já em 1979, com a Instrução CVM n 8/79, e, posteriormente, com a edição da Instrução CVM no 31/84, é somente em 2001 que a proteção dos investidores contra o uso de informações privilegiadas passa a constar expressamente na Lei $\mathrm{n}^{\circ} 6.385 / 76$ como um objetivo a ser seguido pela CVM. 
Sobre o objetivo da reforma promovida na Lei ${ }^{\circ} 6.385 / 76$ pela Lei $n^{\circ}$ 10.303/01 no que tange à inclusão da alínea "c" ao inciso IV do Art. $4^{\circ}$, vale conferir as lições de CHEDIAK:

Quando a Lei 6.385 se refere a evitar fraudes ou manipulações, ou a assegurar o
acesso a informações, ou ainda a assegurar a observância de práticas comerciais
equitativas no mercado, já está autorizando a Comissão de Valores Mobiliários a
proteger os investidores contra o "uso de informação relevante não divulgada no
mercado de valores mobiliários". Como há na lei, porém, referência expressa a
outras situações em que o investidor deveria ser protegido, não havendo referência
clara ao uso indevido de informação relevante, sempre se poderia argumentar que a
Comissão de Valores Mobiliários estaria impedida de exercer sua função
regulamentar de forma a proteger os investidores contra o uso indevido de
informações relevantes, quando se tratasse de uso de informações por quem não
integrasse a administração da companhia, já que a legislação societária, quando se
referia ao dever de informar, incluía apenas os administradores da companhia aberta,
e não qualquer terceiro que tenha acesso a informações relevantes, não conhecidas do
público.

Essa argumentação, porém, não deveria prosperar - como, aliás, não vinha prosperando nos precedentes da própria Comissão - já que existia, no texto da lei, antes da reforma, amplitude suficiente para permitir que a Comissão de Valores Mobiliários buscasse a defesa de qualquer investidor contra o uso, por qualquer pessoa, de informações relevantes não divulgadas ao mercado.

O legislador parece ter pretendido, porém, tornar essa questão ainda mais clara, inclusive com a inserção, pela Lei 10.303 , de um novo $\S 4^{\circ}$, no art. 155 da Lei 6.404, "vedando a utilização de informação relevante ainda não divulgada, por qualquer pessoa que a ela tenha tido acesso, com a finalidade de auferir vantagem, para si ou para outrem, no mercado de valores mobiliários". ${ }^{164}$

Entretanto, a principal inovação no combate ao insider trading trazida pela Lei $n^{\circ} 10.303 / 01$ e incorporada à Lei ${ }^{\circ}$ 6.385/76 diz respeito à inclusão do Art. 27-D, que criminalizou a utilização de informação privilegiada por certas pessoas, notadamente aquelas que têm acesso a informações relevantes e confidenciais e que, ao mesmo tempo, têm o dever de manter sigilo sobre elas.

\footnotetext{
${ }^{164}$ CHEDIAK., Julian Fonseca Peña. A Reforma do Mercado de Valores Mobiliários. In: LOBO, Jorge (org.). A Reforma da lei de Sociedades Anônimas: inovações e questões controvertidas da Lei $n^{\circ}$ 10.303, de 31.10.2001. Rio de Janeiro: Forense, 2002. p. 539-540.
} 
Em nome da sistematização proposta no início deste trabalho, o estudo do Art. 27-D da Lei $n^{\circ}$ 6.385/76 e as consequências penais do insider trading serão aprofundados no item 4.6.3 abaixo.

\subsection{A Instrução CVM n ${ }^{\circ} 358 / 02$}

A Instrução CVM n 358/02 é o normativo que, atualmente, regula e preenche os contornos genéricos sobre insider trading traçados pela Lei $\mathrm{n}^{\circ}$ 6.404/76 e pela Lei $n^{\circ}$ 6.385/76, além de trazer regras sobre a prestação de informações pelas companhias abertas. ${ }^{165}$

Primeiramente, cabe esclarecer que a Instrução CVM n ${ }^{\circ}$ 358/02 não foi a primeira norma emanada pela CVM a regular o insider trading no Brasil. Antes dela, as Instruções CVM n ${ }^{\circ} 8 / 79^{166}$ e $31 / 84$ - esta última atualmente revogada pela Instrução CVM n ${ }^{\circ}$ 358/02 - também regularam a matéria. No entanto, tendo em vista que desde 2002 os casos de insider trading perante a CVM vêm sendo conduzidos com base na Instrução CVM n ${ }^{\circ}$ 358/02, me limitarei, para fins do presente trabalho, ao estudo desta Instrução. ${ }^{167}$

\footnotetext{
${ }^{165}$ Conforme observado por Marcelo Trindade, "a edição da Instrução 358/2002 deu-se, entre outras finalidades, para regulamentar a aplicação dos dispositivos legais, antigo e novo, que vedam a conduta de negociação com utilização de informação privilegiada". TRINDADE, Marcelo Fernandez. Vedações à Negociação de Valores Mobiliários por Norma Regulamentar: Interpretação $e$ Legalidade. Temas de Direito Societário Empresarial Contemporâneos. São Paulo: Malheiros, 2011. p. 457.

${ }^{166}$ A Instrução CVM n ${ }^{\circ}$ 8/79 trouxe o conceito de "prática não equitativa", definindo-a como "aquela de que resulte, direta ou indiretamente, efetiva ou potencialmente, um tratamento para qualquer das partes, em negociações com valores mobiliários, que a coloque em uma indevida posição de desequilíbrio ou desigualdade em face dos demais participantes da operação". Conforme relembrado por Nelson Eizirik, "o preceito [de prática não equitativa] foi utilizado durante algum tempo para a repressão ao insider trading praticado por intermediários financeiros e demais participantes do mercado, ao tempo em que não havia normas reprimindo diretamente a sua conduta [...]".EIZIRIK, Nelson Laks; GAAL, Ariádna B.; PARENTE, Flávia; HENRIQUES, Marcus de Freitas. Mercado de Capitais - regime jurídico. 2. ed. (revisada e atualizada). Rio de Janeiro: Renovar, 2008. p. 534.

${ }^{167}$ Para um aprofundamento das discussões sobre o uso de informações privilegiadas no âmbito das Instruções CVM n ${ }^{\circ}$ 8/79 e 31/84, confira-se, respectivamente, EIZIRIK, Nelson Laks. Insider Trading e a Responsabilidade de Administrador de Companhia Aberta. Revista de Direito Mercantil, Industrial, Econômico e Financeiro. São Paulo: ${ }^{\circ}$ 50, ano XXII, abr.-jun. 1983; e EIZIRIK, Nelson Laks. A Instrução CVM 31/84 e a Regulamentação do "Insider Trading". Revista de Direito Mercantil, Industrial, Econômico e Financeiro. São Paulo: n 55, ano XXIII, jul.-set. 1984. Para um
} 
A vedação ao insider trading encontra-se capitulada no Art. 13 da Instrução CVM n $\mathrm{n}^{\circ}$ 358/02, sendo este o principal dispositivo de caráter repressivo ao uso de informações privilegiadas:

Art. 13. Antes da divulgação ao mercado de ato ou fato relevante ocorrido nos negócios da companhia, é vedada a negociação com valores mobiliários de sua emissão, ou a eles referenciados, pela própria companhia aberta, pelos acionistas controladores, diretos ou indiretos, diretores, membros do conselho de administração, do conselho fiscal e de quaisquer órgãos com funções técnicas ou consultivas, criados por disposição estatutária, ou por quem quer que, em virtude de seu cargo, função ou posição na companhia aberta, sua controladora, suas controladas ou coligadas, tenha conhecimento da informação relativa ao ato ou fato relevante.

$\S 1^{\circ}$ - A mesma vedação aplica-se a quem quer que tenha conhecimento de informação referente a ato ou fato relevante, sabendo que se trata de informação ainda não divulgada ao mercado, em especial àqueles que tenham relação comercial, profissional ou de confiança com a companhia, tais como auditores independentes, analistas de valores mobiliários, consultores e instituições integrantes do sistema de distribuição, aos quais compete verificar a respeito da divulgação da informação antes de negociar com valores mobiliários de emissão da companhia ou a eles referenciados.

$\S 2^{\circ}$ - Sem prejuízo do disposto no parágrafo anterior, a vedação do caput se aplica também aos administradores que se afastem da administração da companhia antes da divulgação pública de negócio ou fato iniciado durante seu período de gestão, e se estenderá pelo prazo de seis meses após o seu afastamento.

$\S 3^{\circ}$ - A vedação do caput também prevalecerá:

I - se existir a intenção de promover incorporação, cisão total ou parcial, fusão, transformação ou reorganização societária; e

II - em relação aos acionistas controladores, diretos ou indiretos, diretores e membros do conselho de administração, sempre que estiver em curso a aquisição ou a alienação de ações de emissão da companhia pela própria companhia, suas controladas, coligadas ou outra sociedade sob controle comum, ou se houver sido outorgada opção ou mandato para o mesmo fim.

$\S 4^{\circ}$ - Também é vedada a negociação pelas pessoas mencionadas no caput no período de 15 (quinze) dias que anteceder a divulgação das informações trimestrais (ITR) e anuais (DFP) da companhia, ressalvado o disposto no $\S 3^{\circ}$ do art. 15.

$\S 5^{\circ}$ - As vedações previstas no caput e nos $\S \S 1^{\circ}, 2^{\circ}$, e $3^{\circ}$, inciso I, deixarão de vigorar tão logo a companhia divulgue o fato relevante ao mercado, salvo se a

estudo comparativo das duas Instruções acima mencionadas, recomendamos a leitura de APRIGLIANO, Ricardo de Carvalho. Insider Trading. Comentário de Ricardo de Carvalho Aprigiliano ao acórdão do Tribunal de Justiça de São Paulo na Apelação Cível n. 12.145-1. Revista de Direito Mercantil, Industrial, Econômico e Financeiro. São Paulo: n 109, ano XXII, abr.-jun. 1983 
negociação com as ações puder interferir nas condições dos referidos negócios, em prejuízo dos acionistas da companhia ou dela própria.

$\S 6^{\circ}$ - A vedação prevista no caput não se aplica à aquisição de ações que se encontrem em tesouraria, através de negociação privada, decorrente do exercício de opção de compra de acordo com plano de outorga de opção de compra de ações aprovado em assembleia geral.

$\S 7^{\circ}$ - As vedações previstas no caput e nos $\S \S 1^{\circ}$ a $3^{\circ}$ não se aplicam às negociações realizadas pela própria companhia aberta, pelos acionistas controladores, diretos ou indiretos, diretores, membros do conselho de administração, do conselho fiscal e de quaisquer órgãos com funções técnicas ou consultivas, criados por disposição estatutária, de acordo com política de negociação aprovada nos termos do art. 15.

Conforme observado por TRINDADE, o “caput do art. 13 da Instrução 358/2002 regulamentou a vedação imposta aos insiders típicos”, quais sejam, os diretores, conselheiros, membros do conselho fiscal, acionista controlador e membros de outros órgãos internos da companhia criados pelo estatuto.

Já o parágrafo $1^{\circ}$ do Art. 13 da Instrução CVM n ${ }^{\circ}$ 358/02, continua o autor, "regulamentou a nova norma do $\S 4^{\circ}$ do art. 155 da Lei das S/A destinada a alcançar 'quaisquer pessoas' que tivessem acesso à informação privilegiada". ${ }^{168}$

Ademais, o parágrafo $4^{\circ}$ do Art. 13 da Instrução CVM n 358/02 traz uma vedação adicional à negociação de valores mobiliários no período de 15 (quinze) dias que anteceder a divulgação das informações trimestrais (ITR) e anuais (DFP) da companhia. Durante este período de vedação, conhecido pelo jargão em inglês "black-out period", há uma presunção absoluta de que as pessoas mencionadas no caput do Art. 13 detêm informações relevantes sobre a companhia relativas à sua situação financeira, não podendo, portanto, negociar com valores mobiliários de sua emissão.

\footnotetext{
168 TRINDADE, Marcelo Fernandez. Vedações à Negociação de Valores Mobiliários por Norma Regulamentar: Interpretação e Legalidade. Temas de Direito Societário Empresarial Contemporâneos. São Paulo: Malheiros, 2011. p. 457-458.
} 
Além dos comandos eminentemente repressivos trazidos pelo Art. 13 da Instrução CVM n ${ }^{\circ}$ 358/02, diversos outros dispositivos da referida Instrução cumprem o papel de normas preventivas contra o insider trading. É o caso, por exemplo, do Art. $8^{\circ}$, que aumentou o alcance subjetivo do dever de guardar sigilo, ao prever o seguinte:

Art. $8^{\circ}$ - Cumpre aos acionistas controladores, diretores, membros do conselho de administração, do conselho fiscal e de quaisquer órgãos com funções técnicas ou consultivas, criados por disposição estatutária, e empregados da companhia, guardar sigilo das informações relativas a ato ou fato relevante às quais tenham acesso privilegiado em razão do cargo ou posição que ocupam, até sua divulgação ao mercado, bem como zelar para que subordinados e terceiros de sua confiança também o façam, respondendo solidariamente com estes na hipótese de descumprimento.

Outra norma de caráter preventivo está disposta no Art. 11 e seus parágrafos da Instrução CVM n ${ }^{\circ} 358 / 02$. O caput do referido artigo estabelece que "os diretores, os membros do conselho de administração, do conselho fiscal e de quaisquer órgãos com funções técnicas ou consultivas criados por disposição estatutária ficam obrigados a informar à companhia a titularidade e as negociações realizadas com valores mobiliários emitidos pela própria companhia, por suas controladoras ou controladas, nestes dois últimos casos, desde que se trate de companhias abertas."

O parágrafo $2^{\circ}$ do mencionado artigo prevê que as pessoas mencionadas no caput deverão informar, ainda, "os valores mobiliários que sejam de propriedade de cônjuge do qual não estejam separados judicialmente, de companheiro(a), de qualquer dependente incluído em sua declaração anual de imposto sobre a renda e de sociedades por elas controladas direta ou indiretamente."

Todas estas informações, diz o parágrafo $5^{\circ}$, deverão ser enviadas “à CVM e, se for o caso, às bolsas de valores ou às entidades do mercado de balcão organizado em que as ações da companhia sejam admitidas à negociação, no prazo de 10 (dez) dias, após o término do mês em que se 
verificarem alterações das posições detidas, ou do mês em que ocorrer a investidura no cargo das pessoas citadas no caput."

Como se percebe, à semelhança do que já foi dito a respeito do Art. 157 da Lei n ${ }^{\circ}$ 6.404/76, o Art. 11 da Instrução CVM n 358/02 representa mais um mecanismo de prevenção contra o insider trading, na medida em que permite que a CVM, as bolsas de valores e a própria companhia monitorem constantemente as negociações de valores mobiliários por pessoas que, em regra, estão em contato potencial e constante com informações relevantes e sigilosas.

Prosseguindo, os comandos previstos no Art. 12 da Instrução CVM n ${ }^{\circ}$ 358/02 exigem que "acionistas controladores, diretos ou indiretos, e os acionistas que elegerem membros do Conselho de Administração ou do conselho fiscal, bem como qualquer pessoa natural ou jurídica, ou grupo de pessoas, agindo em conjunto ou representando um mesmo interesse, que atingir participação, direta ou indireta, que corresponda a 5\% (cinco por cento) ou mais de espécie ou classe de ações representativas do capital de companhia aberta" enviem à CVM uma série de informações, possuindo finalidade semelhante à do Art. 11 .

Além disso, os parágrafos $1^{\circ 169}$ e $4^{\circ 170}$ do Art. 12 permitem que a CVM monitore constantemente as movimentações mais relevantes na posição acionária das pessoas acima mencionadas, também com o intuito de prevenir

\footnotetext{
${ }^{169} \S 1^{\circ}$ - Está igualmente obrigada à divulgação das mesmas informações a pessoa ou grupo de pessoas representando um mesmo interesse, titular de participação acionária igual ou superior ao percentual referido no caput deste artigo, a cada vez que a referida participação se eleve em 5\% (cinco por cento) da espécie ou classe de ações representativas do capital social da companhia.

$170 \S 4^{\circ}$ - As pessoas mencionadas no caput deste artigo também deverão informar a alienação ou a extinção de ações e demais valores mobiliários mencionados neste artigo, ou de direitos sobre eles, a cada vez que a participação do titular na espécie ou classe dos valores mobiliários em questão atingir o percentual de $5 \%$ (cinco por cento) do total desta espécie ou classe e a cada vez que tal participação se reduzir em $5 \%$ (cinco por cento) do total da espécie ou classe.
} 
que tais pessoas, ao tomar conhecimento de informações relevantes e sigilosas, negociem com ações da companhia antes da devida divulgação ao público.

\subsection{A Instrução CVM $n^{\circ} 400 / 03$}

Outro normativo utilizado no combate ao insider trading é a Instrução $\mathrm{CVM} \mathrm{n}^{\circ} 400 / 03$, que teve como principal finalidade "assegurar a proteção dos interesses do público investidor e do mercado em geral, através do tratamento equitativo aos ofertados e de requisitos de ampla, transparente e adequada divulgação de informações sobre a oferta, os valores mobiliários ofertados, a companhia emissora, o ofertante e demais pessoas envolvidas" (cf. Art. $1^{\circ}$ da Instrução CVM n 400/03).

\section{Conforme apontado por TRINDADE,}

Essa preocupação com a proteção dos interesses dos investidores e demais participantes do mercado se faz presente em diversos dos dispositivos da Instrução 400/2003. Entre outros dispositivos, merece destaque o art. 21 daquela Instrução, que estabelece que as ofertas públicas "deverão ser realizadas em condições que assegurem tratamento equitativo aos destinatários e aceitantes das ofertas". ${ }^{171}$

A regra, porém, mais diretamente relacionada ao combate ao insider trading encontra-se prevista no Art. 48, II da Instrução CVM n ${ }^{\circ} 400 / 03$, com redação dada pela Instrução CVM nº 533/2013:

Art. 48. A emissora, o ofertante, as Instituições Intermediárias, estas últimas desde a contratação, envolvidas em oferta pública de distribuição, decidida ou projetada, e as pessoas que com estes estejam trabalhando ou os assessorando de qualquer forma, deverão, sem prejuízo da divulgação pela emissora das informações periódicas e eventuais exigidas pela CVM:

\section{$[\ldots]$}

II - abster-se de negociar, até a publicação do Anúncio de Encerramento de Distribuição, com valores mobiliários do mesmo emissor e espécie daquele objeto da oferta pública, nele referenciados, conversíveis ou permutáveis, ou com valores

\footnotetext{
171 TRINDADE, Marcelo Fernandez. Vedações à Negociação de Valores Mobiliários por Norma Regulamentar: Interpretação e Legalidade. Temas de Direito Societário Empresarial Contemporâneos. São Paulo: Malheiros, 2011. p. 460.
} 
mobiliários nos quais o valor mobiliário objeto da oferta seja conversível ou permutável, salvo nas hipóteses de:

a) execução de plano de estabilização devidamente aprovado pela CVM;

b) alienação total ou parcial de lote de valores mobiliários objeto de garantia firme;

c) negociação por conta e ordem de terceiros;

d) operações claramente destinadas a acompanhar índice de ações, certificado ou recibo de valores mobiliários;

e) operações destinadas a proteger posições assumidas em derivativos contratados com terceiros;

f) operações realizadas como formador de mercado, nos termos da regulamentação aplicável;

g) administração discricionária de carteira de terceiros;

h) aquisição de valores mobiliários solicitada por clientes com o fim de prover liquidez, bem como a alienação dos valores mobiliários assim adquiridos;

i) arbitragem entre:

1. valores mobiliários e seus certificados de depósito; ou

2. índice de mercado e contrato futuro nele referenciado; e

j) operações destinadas a cumprir obrigações assumidas antes do início do período de vedação decorrentes de:

1. empréstimos de valores mobiliários;

2. exercício de opções de compra ou venda por terceiros; ou

3. contratos de compra e venda a termo.

O MEMO/SRE/N ${ }^{\circ}$ 215/2004, aprovado pelo colegiado da CVM em 25.10.2004, deixou claro o objetivo da norma supracitada no que tange ao combate ao uso de informações privilegiadas:

Resumidamente, o objetivo da disposição contida no art. 48 da Instrução, de vedar a negociação de valores mobiliários de emissão do ofertante ou da emissora dos valores em oferta pelas pessoas envolvidas na oferta pública, é o de evitar distorções no mercado e de proteger os interesses dos investidores, nas hipóteses de negociação de posse de informação privilegiada e de negociação que possa influenciar na precificação dos valores mobiliários ofertados. 
Acreditamos que a dificuldade de separar as operações realizadas sem a posse de informação privilegiada ou sem o objetivo de influenciar o preço do valor mobiliário ofertado, daquelas que podem implicar em tais ilícitos, levou o legislador a restringir totalmente a condução de negócios, por ofertantes e intermediários envolvidos na oferta pública, com quaisquer valores mobiliários de emissão da companhia.

Desta forma, o comando contido no Art. 48, II da Instrução CVM n ${ }^{\circ}$ 400/03 previne que aquelas pessoas diretamente envolvidas na oferta pública e que, portanto, estão em contato com informações relevantes e sigilosas a todo instante, se utilizem de tais informações para negociar com os valores mobiliários emitidos em condições mais vantajosas que aqueles que não detêm tais informações.

\subsection{Consequências do insider trading}

Vistas, assim, as normas que, atualmente, regulam, previnem e combatem o insider trading, passa-se, em seguida, a identificar as consequências que podem advir para aqueles que se utilizam de informações relevantes e sigilosas para comprar ou vender valores mobiliários no mercado.

De acordo com o arcabouço regulatório atualmente em vigor, a utilização de informação relevante antes de sua divulgação ao mercado pode ensejar responsabilidade civil, administrativa e penal. A seguir, será abordado o tratamento legal de cada uma dessas responsabilidades.

\subsubsection{Responsabilidade Civil}

O parágrafo $2^{\circ}$ do Art. 155 exige que o administrador cuide para que o uso de informações relevantes ainda não divulgadas não ocorra através de subordinados ou terceiros de sua confiança. Caso isto aconteça, observa EIZIRIK, "cabe da mesma forma a aplicação de penalidades pela CVM e a 
ação de indenização promovida pelos prejudicados, ambas contra o infrator e o administrador." $172 / 173$

$\mathrm{O}$ parágrafo $3^{\circ}$ do mesmo artigo, por sua vez, garante à pessoa prejudicada em compra e venda de valores mobiliários contratada com infração aos parágrafos $1^{\circ}$ e $2^{\circ}$, o direito de haver do infrator indenização por perdas e danos.

Tal dispositivo acabou por restringir a responsabilidade civil pela prática de insider trading apenas aos administradores latu sensu e aos subordinados e terceiros de sua confiança. Isto porque para que a operação de compra e venda de valores mobiliários seja passível de indenização por perdas e danos, é necessário que ela se dê com infração aos parágrafos $1^{\circ}$ e $2^{\circ}$ do Art. 155 e, como visto, o parágrafo $1^{\circ}$ do Art. 155 veda a prática de insider trading somente aos administradores, impondo-lhes, ainda, o dever de sigilo, enquanto o parágrafo $2^{\circ}$ do mesmo artigo exige que os administradores cuidem para que tais violações não ocorram por meio de subordinados e terceiros de sua confiança.

Assim, em uma interpretação literal, somente administradores, seus subordinados e terceiros de sua confiança estariam obrigados a reparar, na esfera civil, os prejuízos eventualmente causados com a prática do insider trading.

Compartilhando deste entendimento, EIZIRIK sustenta, ainda, que

[...] a responsabilidade na esfera civil existe apenas para os insiders que efetivamente estão dentro da companhia (administradores, diretores, acionistas controladores e

${ }^{172}$ EIZIRIK, Nelson Laks; e NETTO, Horácio de Mendonça. O Privilegiamento de Informações e o Caso Petrobrás. Revista Brasileira de Mercado de Capitais, Rio de Janeiro, v. 4, n. 10, jan./abr. 1978. p. 14.

${ }^{173}$ Para uma análise das consequências do insider trading à luz da legislação civil brasileira vigente à época da promulgação da Lei ${ }^{\circ}$ 6.404/76, confira-se PARENTE, Norma. Aspectos Jurídicos do "Insider Trading”. CVM. Superintendência Jurídica, Junho de 1978. p. 15-17. 
empregados da empresa) eis que somente a eles a Lei das S/A atribui o "dever de informar".

E justifica:

Isto porque, são os insiders que efetivamente estão dentro da empresa que estão submetidos ao princípio do disclose or refrain from trading. Os intermediários financeiros e demais participantes do mercado não estão obrigados a revelar publicamente as informações confidenciais da companhia às quais tiveram acesso $[\ldots]$.

Conforme foi observado, é a não divulgação de informações que pode causar prejuízos, não a simples negociação com as ações da empresa. Daí ser remota a possibilidade de reparação de danos, os quais, se a informação confidencial não for jamais trazida a público, não alterando, portanto, a cotação das ações, simplesmente não existirão. ${ }^{174}$

Sugerindo uma solução alternativa, PARENTE sustenta ter a Lei $\mathrm{n}^{\circ}$ 6.404/76 transferido implicitamente ao administrador o encargo de cuidar para que a informação privilegiada não fosse usada por terceiros, ficando, neste caso, sujeito a reparar os prejuízos eventualmente causados para, posteriormente, reclamar o que pagou em ação de regresso. No original:

Este dispositivo [Art. 155, $\S 3^{\circ}$ da Lei $n^{\circ}$ 6.404/76] é bastante amplo e responsabiliza sobremaneira as pessoas acima indicadas. Eis que estas respondem por atos seus, de seus subordinados, e de terceiros de sua confiança, e, no caso específico de "insider trading", por atos dessas pessoas e de outras a quem estas tenham transmitido essas informações. Isto resulta em abranger praticamente qualquer pessoa. Esta última categoria de pessoas o legislador as abrange, ao usar a expressão "para si ou para outrem".

Note-se que os dispositivos em exame [Art. 155, $\S \S 2^{\circ}$ e $3^{\circ}$ da Lei $n^{\circ}$ 6.404/76] pretenderam, a todo modo, garantir ao investidor a certeza de que, se prejudicado com a prática do "insider trading", teria a correspondente indenização em perdas e danos e, ainda, impor ao administrador o encargo de, a duras penas, impedir que isso ocorra.

Acreditamos, mais, que as mencionadas disposições tiveram o intuito de evitar que o investidor prejudicado ficasse à procura de quem responsabilizar pelo ato ilícito. Elas transferiram implicitamente este encargo para o administrador que, em etapa

${ }^{174}$ EIZIRIK, Nelson Laks. Insider Trading e a Responsabilidade de Administrador de Companhia Aberta. Revista de Direito Mercantil, Industrial, Econômico e Financeiro. São Paulo: ${ }^{\circ}$ 50, ano XXII, abr.-jun. 1983. p. 43. 
posterior, por sua vez, poderá reclamar o que pagou a quem efetivamente praticou o "insider trading". ${ }^{175}$

Ressalte-se que ambos os trabalhos citados imediatamente acima foram escritos e publicados antes da reforma promovida na Lei ${ }^{\circ} 6.404 / 76$ pela Lei $\mathrm{n}^{\circ} 10.303 / 01$, que, conforme já mencionado, incluiu o parágrafo $4^{\circ}$ do Art. 155, para vedar a utilização de informação privilegiada por qualquer pessoa, e não só pelos administradores, subordinados e terceiros de sua confiança.

Assim, poder-se-ia sustentar que, em uma interpretação sistemática dos $\S \S 1^{\circ}, 2^{\circ}, 3^{\circ}$ e $4^{\circ}$ do Art. 155 da Lei $n^{\circ}$ 6.404/76, a reparação por perdas e danos poderia ser pleiteada por eventual prejudicado contra toda e qualquer pessoa que se utilizasse de informações privilegiadas para negociar com valores mobiliários.

Este parece ser o posicionamento de CARVALHOSA, que, comentando o Art. 155 e seus parágrafos já em sua redação atual, sustenta:

Deverá ressarcir as perdas e danos havidos toda e qualquer pessoa que se tenha utilizado de informações sigilosas ou reservadas, de caráter relevante, para negociar com valores mobiliários no mercado de capitais no período anterior à divulgação, pelos canais institucionais, dos respectivos fatos ou negócios. ${ }^{176}$

Ressalte-se, ainda, que além das pessoas diretamente prejudicadas pelo insider com a operação de compra e venda de valores mobiliários no mercado,

175 PARENTE, Norma. Aspectos Jurídicos do "Insider Trading". CVM. Superintendência Jurídica, Junho de 1978. p. 12. Em sentido semelhante, LEÃES sustenta, ao discutir sobre a legitimidade passiva da ação de reparação por perdas e danos causados pela prática de insider trading, que "na responsabilidade por fato de terceiro, como é o caso, prevalece o princípio geral de que os responsáveis diretos são solidários para com os responsáveis indiretos, como assenta o parágrafo único do art. 1.518, combinado com o art. 1.521, do Código Civil [que correspondem, hoje, respectivamente, ao parágrafo único do Art. 942 e ao Art. 932, do novo Código Civil]. Essa solidariedade passiva legitima, assim, plenamente, que se proponha ação de indenização diretamente contra aqueles que receberam dos administradores informações confidenciais, os chamados tippers e sub-tippers. LEÃES, Luiz Gastão Paes de Barros. Mercado de Capitais \& "Insider Trading". $1^{a}$ ed. São Paulo: Ed. Revista dos Tribunais, 1978. p. 189.

176 CARVAlHOSA, Modesto. Comentários à Lei das Sociedades Anônimas. 4. ed. São Paulo. Saraiva, 2009. vol. 3, p. 314. 
a doutrina ${ }^{177}$ aponta que a própria companhia emissora de tais valores mobiliários poderia propor ação de responsabilidade civil para reaver eventuais danos a ela causados, principalmente se a negociação com base em informações privilegiadas fosse realizada por administrador da companhia, caso em que a ação de responsabilidade encontraria amparo legal nos Arts. $158^{178}$ e $159^{179}$ da Lei $n^{\circ} 6.404 / 76$. Tais danos decorreriam, por exemplo, da publicidade negativa derivada da revelação do caso de insider trading ao

177 SCALZILLI, João Pedro; SPINELLI, Luis Felipe. A Racionalidade Econômica do Combate ao Insider Trading: Assimetria de Informação e Dano ao Mercado. Revista de Direito Mercantil, Industrial, Econômico e Financeiro. São Paulo: n 147, ano XLVI, jul.-set. 2007. p. 46.

${ }^{178}$ Art. 158. O administrador não é pessoalmente responsável pelas obrigações que contrair em nome da sociedade e em virtude de ato regular de gestão; responde, porém, civilmente, pelos prejuízos que causar, quando proceder:

I - dentro de suas atribuições ou poderes, com culpa ou dolo;

II - com violação da lei ou do estatuto.

$\S 1^{\circ} \mathrm{O}$ administrador não é responsável por atos ilícitos de outros administradores, salvo se com eles for conivente, se negligenciar em descobri-los ou se, deles tendo conhecimento, deixar de agir para impedir a sua prática. Exime-se de responsabilidade o administrador dissidente que faça consignar sua divergência em ata de reunião do órgão de administração ou, não sendo possível, dela dê ciência imediata e por escrito ao órgão da administração, no conselho fiscal, se em funcionamento, ou à assembleia geral.

$\S 2^{\circ}$ Os administradores são solidariamente responsáveis pelos prejuízos causados em virtude do não cumprimento dos deveres impostos por lei para assegurar o funcionamento normal da companhia, ainda que, pelo estatuto, tais deveres não caibam a todos eles.

$\S 3^{\circ}$ Nas companhias abertas, a responsabilidade de que trata o $\S 2^{\circ}$ ficará restrita, ressalvado o disposto no $\S 4^{\circ}$, aos administradores que, por disposição do estatuto, tenham atribuição específica de dar cumprimento àqueles deveres.

$\S 4^{\circ} \mathrm{O}$ administrador que, tendo conhecimento do não cumprimento desses deveres por seu predecessor, ou pelo administrador competente nos termos do $\$ 3^{\circ}$, deixar de comunicar o fato a assembleia geral, tornar-se-á por ele solidariamente responsável.

$\S 5^{\circ}$ Responderá solidariamente com o administrador quem, com o fim de obter vantagem para si ou para outrem, concorrer para a prática de ato com violação da lei ou do estatuto.

179 Art. 159. Compete à companhia, mediante prévia deliberação da assembleia geral, a ação de responsabilidade civil contra o administrador, pelos prejuízos causados ao seu patrimônio.

$\S 1^{\circ}$ A deliberação poderá ser tomada em assembleia geral ordinária e, se prevista na ordem do dia, ou for consequência direta de assunto nela incluído, em assembleia geral extraordinária.

$\S 2^{\circ} \mathrm{O}$ administrador ou administradores contra os quais deva ser proposta ação ficarão impedidos e deverão ser substituídos na mesma assembleia.

$\S 3^{\circ}$ Qualquer acionista poderá promover a ação, se não for proposta no prazo de 3 (três) meses da deliberação da assembleia geral.

$\S 4^{\circ}$ Se a assembleia deliberar não promover a ação, poderá ela ser proposta por acionistas que representem 5\% (cinco por cento), pelo menos, do capital social.

$\S 5^{\circ}$ Os resultados da ação promovida por acionista deferem-se à companhia, mas esta deverá indenizálo, até o limite daqueles resultados, de todas as despesas em que tiver incorrido, inclusive correção monetária e juros dos dispêndios realizados.

$\S 6^{\circ} \mathrm{O}$ juiz poderá reconhecer a exclusão da responsabilidade do administrador, se convencido de que este agiu de boa-fé e visando ao interesse da companhia.

$\S 7^{\circ}$ A ação prevista neste artigo não exclui a que couber ao acionista ou terceiro diretamente prejudicado por ato de administrador. 
público e da eventual diminuição de sua capacidade de recorrer à poupança popular na captação de recursos.

Outra discussão relacionada às consequências do insider trading à luz do Direito Civil diz respeito à opção do legislador em não prever a possibilidade de anulação da operação realizada por quem se utiliza de informação privilegiada. Neste ponto, LUCENA observa que a anulação

[...] encontraria lastro, na época [da promulgação da Lei $n^{\circ}$ 6.404/76], no artigo 94, do Código Civil/1916, e, hoje, no artigo 147 do Código Civil/2002, já que o insider sonega dolosamente à outra parte (o outsider) informação relevante de que somente ele tem conhecimento, tanto que vem a influir de modo ponderável na cotação dos valores mobiliários por ambos negociados, gerando um dano indenizável para o outsider.

\section{E assevera:}

A razão da opção do legislador tão-somente pela indenização do prejudicado, sem permitir a anulação do ato negocial dos valores mobiliários, decorre da ponderação entre os interesses então em jogo. Assim, do ponto de vista do lesado, basta-lhe o ressarcimento dos prejuízos que teve com o comportamento do insider. Já a anulação do ato negocial, com repercussões fora do restrito círculo dos envolvidos no negócio, traria de um modo geral intranquilidade aos investidores que confiam na seriedade e eficiência do mercado. ${ }^{180}$

De fato, conforme conclui PARENTE,

[...] o legislador, cônscio da dificuldade que seria a prestação da obrigação "in natura", e visando assegurar estabilidade no mercado, previu, para a hipótese, a reparação do dano mediante o pagamento de indenização. Na realidade, o legislador, por razões lógicas e práticas, entre determinar a anulação da operação e a reparação do dano, mediante o pagamento de indenização, optou por esta última medida. ${ }^{181}$

Por fim, cabe acrescentar que a Lei ${ }^{\circ} 7.913 / 89$, que dispõe sobre a ação civil pública de responsabilidade por danos causados aos investidores no mercado de valores mobiliários, previu a possibilidade de que o ressarcimento pelos danos causados por quem utiliza informações privilegiadas para negociar

\footnotetext{
${ }^{180}$ LUCENA, José Waldecy. Das Sociedades Anônimas - comentários à lei (arts. 121 a 188). Vol. 2. Rio de Janeiro: Renovar, 2009. p. 498-499

181 PARENTE, Norma. Aspectos Jurídicos do "Insider Trading”. CVM. Superintendência Jurídica, Junho de 1978. p. 12.
} 
com valores mobiliários no mercado fosse pleiteado pelo Ministério Público, por meio de ação civil pública.

Referida lei prevê em seu Art. $1^{\circ}$, II o seguinte:

Art. $1^{\circ}$ Sem prejuízo da ação de indenização do prejudicado, o Ministério Público, de ofício ou por solicitação da Comissão de Valores Mobiliários - CVM, adotará as medidas judiciais necessárias para evitar prejuízos ou obter ressarcimento de danos causados aos titulares de valores mobiliários e aos investidores do mercado, especialmente quando decorrerem de:

$[\ldots]$

II - compra ou venda de valores mobiliários, por parte dos administradores e acionistas controladores de companhia aberta, utilizando-se de informação relevante, ainda não divulgada para conhecimento do mercado, ou a mesma operação realizada por quem a detenha em razão de sua profissão ou função, ou por quem quer que a tenha obtido por intermédio dessas pessoas;

Dessa forma, além do investidor lesado, o Ministério Público poderá, na forma da referida lei, obter por meio de ação civil pública reparação pelos danos causados por administrador ou por pessoa que através dele tenha tido acesso e utilizado informações privilegiadas para negociar com valores mobiliários de companhia aberta, sendo certo que, nos termos do Art. $2^{\circ}$, "as importâncias decorrentes da condenação, na ação de que trata esta Lei, reverterão aos investidores lesados, na proporção de seu prejuízo."

\subsubsection{Responsabilidade Administrativa}

Para cumprir o objetivo previsto no Art. $4^{\circ}$, IV, alínea "c" da Lei ${ }^{\circ}$ 6.385/76, acima referido, o Art. $9^{\circ}, \mathrm{V}$ da mesma lei confere à CVM competência para "apurar, mediante processo administrativo, atos ilegais e práticas não equitativas de administradores, membros do conselho fiscal e acionistas de companhias abertas, dos intermediários e dos demais participantes do mercado". 
Em complemento a tal dispositivo, o Art. 11 da Lei n 6.385/76 prevê o seguinte:

Art. 11. A Comissão de Valores Mobiliários poderá impor aos infratores das normas desta Lei, da lei de sociedades por ações, das suas resoluções, bem como de outras normas legais cujo cumprimento lhe incumba fiscalizar, as seguintes penalidades:

I - advertência;

II - multa;

III - suspensão do exercício do cargo de administrador ou de conselheiro fiscal de companhia aberta, de entidade do sistema de distribuição ou de outras entidades que dependam de autorização ou registro na Comissão de Valores Mobiliários;

IV - inabilitação temporária, até o máximo de vinte anos, para o exercício dos cargos referidos no inciso anterior;

V - suspensão da autorização ou registro para o exercício das atividades de que trata esta Lei;

VI - cassação de autorização ou registro, para o exercício das atividades de que trata esta Lei;

VII - proibição temporária, até o máximo de vinte anos, de praticar determinadas atividades ou operações, para os integrantes do sistema de distribuição ou de outras entidades que dependam de autorização ou registro na Comissão de Valores Mobiliários;

VIII - proibição temporária, até o máximo de dez anos, de atuar, direta ou indiretamente, em uma ou mais modalidades de operação no mercado de valores mobiliários.

$\S 1^{\circ}$ - A multa não excederá o maior destes valores:

I - R \$ 500.000,00 (quinhentos mil reais);

II - cinquenta por cento do valor da emissão ou operação irregular; ou

III - três vezes o montante da vantagem econômica obtida ou da perda evitada em decorrência do ilícito.

$\S 2^{\circ}$ Nos casos de reincidência serão aplicadas, alternativamente, multa nos termos do parágrafo anterior, até o triplo dos valores fixados, ou penalidade prevista nos incisos III a VIII do caput deste artigo.

$\S 3^{\circ}$ Ressalvado o disposto no parágrafo anterior, as penalidades previstas nos incisos III a VIII do caput deste artigo somente serão aplicadas nos casos de infração grave, assim definidas em normas da Comissão de Valores Mobiliários. 
$\S 4^{\circ}$ As penalidades somente serão impostas com observância do procedimento previsto no $\S 2^{\circ}$ do art. $9^{\circ}$ desta Lei, cabendo recurso para o Conselho de Recursos do Sistema Financeiro Nacional.

$\S 5^{\circ}$ A Comissão de Valores Mobiliários poderá, a seu exclusivo critério, se o interesse público permitir, suspender, em qualquer fase, o procedimento administrativo instaurado para a apuração de infrações da legislação do mercado de valores mobiliários, se o investigado ou acusado assinar termo de compromisso, obrigando-se a:

I - cessar a prática de atividades ou atos considerados ilícitos pela Comissão de Valores Mobiliários; e

II - corrigir as irregularidades apontadas, inclusive indenizando os prejuízos.

$\S 6^{\circ} \mathrm{O}$ compromisso a que se refere o parágrafo anterior não importará confissão quanto à matéria de fato, nem reconhecimento de ilicitude da conduta analisada.

$\S 7^{\circ} \mathrm{O}$ termo de compromisso deverá ser publicado no Diário Oficial da União, discriminando o prazo para cumprimento das obrigações eventualmente assumidas, e constituirá título executivo extrajudicial.

$\S 8^{\circ}$ Não cumpridas as obrigações no prazo, a Comissão de Valores Mobiliários dará continuidade ao procedimento administrativo anteriormente suspenso, para a aplicação das penalidades cabíveis.

$\S 9^{\circ}$ Serão considerados, na aplicação de penalidades previstas na lei, o arrependimento eficaz e o arrependimento posterior ou a circunstância de qualquer pessoa, espontaneamente, confessar ilícito ou prestar informações relativas à sua materialidade.

§10. A Comissão de Valores Mobiliários regulamentará a aplicação do disposto nos $\S \S 5$ o a 90 deste artigo aos procedimentos conduzidos pelas Bolsas de Valores, Bolsas de Mercadorias e Futuros, entidades do mercado de balcão organizado e entidades de compensação e liquidação de operações com valores mobiliários.

§11. A multa cominada pela inexecução de ordem da Comissão de Valores Mobiliários, nos termos do inciso II do caput do art. 9o e do inciso IV de seu $\S 10$ não excederá a $R \$ 5.000,00$ (cinco mil reais) por dia de atraso no seu cumprimento e sua aplicação independe do processo administrativo previsto no inciso $\mathrm{V}$ do caput do mesmo artigo.

§12. Da decisão que aplicar a multa prevista no parágrafo anterior caberá recurso voluntário, no prazo de dez dias, ao Colegiado da Comissão de Valores Mobiliários, sem efeito suspensivo. 
Da leitura conjunta dos Arts. $9^{\circ}$, inciso V, e 11, caput, pode-se concluir, respaldado pelo entendimento de TAVARES GUERREIRO ${ }^{182}$, que (i) administradores; (ii) membros do conselho fiscal; (iii) acionistas de companhias abertas; (iv) intermediários; e (v) demais participantes do mercado que infringirem (i) a Lei $n^{\circ}$ 6.385/76; (ii) a Lei n $6.404 / 76$; (iii) as Instruções e demais normativos expedidos pela CVM; e (iv) outras normas legais cujo cumprimento incumba à CVM fiscalizar; estarão sujeitos às sanções disciplinares previstas na Lei ${ }^{\circ} 6.385 / 76$.

Conforme exposto acima, a proibição ao uso de informações privilegiadas está, basicamente, prevista em dois diplomas principais, quais sejam a Lei $n^{\circ}$ 6.404/76 (Art. $155, \S \S 1^{\circ}$ e $4^{\circ}$ ) e a Instrução CVM $n^{\circ} 358 / 02$ (Art. 13, caput e $\S \S 1^{\circ}$ a $4^{\circ}$ ). Assim, aqueles que se utilizam de informações relevantes e sigilosas para negociar com ações da companhia infringem tais diplomas, sujeitando-se, portanto às sanções administrativas previstas na Lei $\mathrm{n}^{\circ}$ $6.385 / 76$.

Acrescente-se, ainda, que nos termos do caput do Art. 18 da Instrução $\mathrm{CVM} \mathrm{n}^{\circ} 358 / 02^{183}$, o descumprimento de qualquer dispositivo desta Instrução constitui infração de natureza grave para os fins do $\S 3^{\circ}$ do Art. 11 da Lei $n^{\circ}$ 6.385/76, estando os infratores sujeitos, portanto, a qualquer uma das penas previstas nos incisos I a VIII do Art. 11 da referida lei.

Conforme se depreende da leitura da Lei $\mathrm{n}^{\circ}$ 6.385/76, não há, na esfera administrativa, previsão de reparação dos eventuais danos causados por quem se utiliza de informações privilegiadas, afirmando TAVARES GUERREIRO

${ }^{182}$ GUERREIRO, José Alexandre Tavares. Sobre o poder disciplinar da CVM. Revista de Direito Mercantil, Industrial, Econômico e Financeiro. São Paulo: n 43, ano XX, 1981. p. 68-72.

183 Art. 18. Configura infração grave, para os fins previstos no § 3o do art. 11 da Lei no 6.385/76, a transgressão às disposições desta Instrução.

Parágrafo único. A CVM deverá comunicar ao Ministério Público a ocorrência dos eventos previstos nesta Instrução que constituam crime. 
que carece à CVM legitimação ad causam para dar início a qualquer ação de ressarcimento na esfera privada, fundamentada na responsabilidade aquiliana $^{184}$.

Em sentido semelhante, confira-se a posição de CARVALHOSA:

[...] muito embora tenha a Comissão de Valores Mobiliários competência para apurar, mediante inquérito administrativo, atos ilegais e práticas não equitativas dos administradores de companhias abertas, não lhe outorga a lei legitimidade ativa para promover as medidas judiciais para responsabilizar civilmente os administradores. Fica, assim, a agência governamental restrita ao âmbito das sanções de natureza administrativa e representação penal. Não adotou, portanto, a sistemática brasileira, o regime norte americano que confere à Securities and Exchange Commission legitimidade para propor ações civis contra os administradores. ${ }^{185}$

Dentre as possíveis responsabilidades - civil, administrativa e penal que se pode atribuir a quem se utiliza de informações privilegiadas, a responsabilidade administrativa, notadamente através da imposição de multa pela CVM, é a mais utilizada no Brasil.

\subsubsection{Responsabilidade Penal}

Nos termos do Art. 12 da Lei $n^{\circ}$ 6.385/76, quando o inquérito administrativo instaurado concluir pela ocorrência de crime de ação pública, a CVM deverá oficiar ao Ministério Público, para a propositura da ação penal. ${ }^{186}$

Como visto acima, a responsabilidade penal pela prática do insider trading passou a ser prevista somente em 2001, quando a Lei ${ }^{\circ}$ 10.303/01

${ }^{184}$ GUERREIRO, José Alexandre Tavares. Sobre o poder disciplinar da CVM. Revista de Direito Mercantil, Industrial, Econômico e Financeiro. São Paulo: n ${ }^{\circ}$, ano XX, 1981. p. 65.

185 CARVAlhOSA, Modesto. Comentários à Lei das Sociedades Anônimas. 4. ed. São Paulo. Saraiva, 2009. vol. 3, p. 348.

${ }^{186}$ Em sentido semelhante o parágrafo único do Art. 18 da Instrução CVM n 358/02 prevê que "a CVM deverá comunicar ao Ministério Público a ocorrência dos eventos previstos nesta Instrução que constituam crime". A comunicação ao Ministério Público de indícios de crimes de ação pública observados pela CVM também foi prevista no Art. $9^{\circ}$ da Lei Complementar $n^{\circ} 105 / 01$. Acrescente-se, ainda, que em 8 de maio de 2008, a CVM e o Ministério Público firmaram Termo de Cooperação Técnica institucionalizando sua atuação conjunta na repressão aos crimes contra o mercado de capitais, notadamente o insider trading, mediante a troca de informações e conhecimento especializado, de modo a conferir agilidade à sua atuação preventiva e repressiva. 
acrescentou o Art. 27-D à Lei $\mathrm{n}^{\circ}$ 6.385/76. Eis o que prevê referido dispositivo:

Uso Indevido de Informação Privilegiada

Art. 27-D. Utilizar informação relevante ainda não divulgada ao mercado, de que tenha conhecimento e da qual deva manter sigilo, capaz de propiciar, para si ou para outrem, vantagem indevida, mediante negociação, em nome próprio ou de terceiro, com valores mobiliários:

Pena - reclusão, de 1 (um) a 5 (cinco) anos, e multa de até 3 (três) vezes o montante da vantagem ilícita obtida em decorrência do crime.

Anteriormente à inclusão do Art. 27-D à Lei $n^{\circ}$ 6.385-76, buscou-se sem sucesso - responsabilizar penalmente a prática do insider trading, não obstante a falta de previsão legal expressa. Tal tentativa se deu mediante o enquadramento do insider trading no crime de estelionato (Art. 171 do Código Penal $^{187}$ ), sob o argumento de que o uso indevido de informações privilegiadas conteria todos os elementos do tipo previstos no Código Penal e discutidos pela doutrina para a configuração do crime estelionato ${ }^{188}$.

Atualmente, mesmo tipificado expressamente em lei, a responsabilização penal do insider trading ainda encontra alguns obstáculos. $\mathrm{O}$ principal $^{189}$ deles diz respeito ao sujeito ativo do tipo, uma vez que o Art. 27-D da Lei $\mathrm{n}^{\circ}$ 6.385/76 previu que o crime de uso indevido de informações privilegiadas é cometido por aquele que tenha conhecimento e deva manter sigilo sobre informação relevante ainda não divulgada ao mercado. A contrário

\footnotetext{
187 Art. 171 - Obter, para si ou para outrem, vantagem ilícita, em prejuízo alheio, induzindo ou mantendo alguém em erro, mediante artifício, ardil, ou qualquer outro meio fraudulento: Pena - reclusão, de um a cinco anos, e multa, de quinhentos mil réis a dez contos de réis.

${ }^{188}$ Para tais argumentos, veja-se PARENTE, Norma. Aspectos Jurídicos do "Insider Trading”. CVM. Superintendência Jurídica, Junho de 1978. p. 20-23.

${ }_{189}$ Tendo em vista que este trabalho não se destina a abordar o insider trading sob o ponto de vista do Direito Penal, me limitarei a trazer apenas os aspectos principais relacionados ao crime de uso indevido de informações privilegiadas. Para uma análise completa e detalhada sobre os aspectos penais do insider trading, confira-se CASTELLAR, João Carlos. Insider Trading e os Novos Crimes Corporativos. Rio de Janeiro: Ed. Lumen Juris, 2008; e SOUZA, Felipe Drumond Coutinho de. A criminalização do insider trading no direito brasileiro. 110 p. Monografia (Graduação em Direito) Pontifícia Universidade Católica do Rio de Janeiro: Rio de Janeiro, 2010.
} 
sensu, aqueles que não têm o dever de manter sigilo não podem, portanto, cometer o crime previsto no Art. 27-D.

Conforme visto no item 4.2.2 supra, o dever de sigilo imposto pelo parágrafo $1^{\circ}$ do Art. 155 da Lei ${ }^{\circ}$ 6.404/76 é aplicável somente aos membros (i) do conselho de administração; (ii) da diretoria; (iii) de órgãos criados pelo estatuto, com funções técnicas ou destinados a aconselhar os administradores; e (iv) do conselho fiscal.

Por força do Art. 260 da Lei n ${ }^{\circ}$ 6.404/76, referido no item 4.2.1 acima, o dever de sigilo também é estendido, no caso de ofertas públicas, ao ofertante e à instituição financeira intermediária. Extensão semelhante é feita pelo Art. $8^{\circ}$ da Instrução CVM n ${ }^{\circ}$ 358/02, que obriga os acionistas controladores a guardarem sigilo das informações relativas a ato ou fato relevante às quais tenham acesso privilegiado em razão do cargo ou posição que ocupam, até sua divulgação ao mercado.

Finalmente, por força do Art. $22, \S 1^{\circ}, \mathrm{V}$ da Lei $\mathrm{n}^{\circ} 6.385 / 76^{190}$ combinado com o Art. 12 da Instrução CVM n ${ }^{\circ}$ 358/02, acionistas minoritários (assim considerados aqueles com participação de, pelo menos, 5\% no capital social de companhia aberta), também estariam abrangidos pelo dever de guardar sigilo.

Desta forma, a doutrina majoritária, encabeçada, dentre outros, por PROENÇA $^{191}$, EIZIRIK $^{192}$, BITENCOURT $^{193}$ e CASTELLAR ${ }^{194}$, entende que

\footnotetext{
${ }^{190}$ Art . 22. Considera-se aberta a companhia cujos valores mobiliários estejam admitidos à negociação na bolsa ou no mercado de balcão.

$\S 1^{\circ}$ Compete à Comissão de Valores Mobiliários expedir normas aplicáveis às companhias abertas sobre:

$[\ldots]$

$\mathrm{V}$ - informações que devam ser prestadas por administradores, membros do conselho fiscal, acionistas controladores e minoritários, relativas à compra, permuta ou venda de valores mobiliários emitidas pela companhia e por sociedades controladas ou controladoras;

${ }^{191}$ PROENÇA, José Marcelo Martins. Insider Trading. Regime jurídico do uso de informaçães privilegiadas no mercado de capitais. São Paulo: Ed. Quartier Latin, 2005. p. 320.
} 
somente as pessoas acima mencionadas, que por lei ou Instrução da CVM, tem o dever de guardar sigilo, podem ser penalmente responsabilizadas pelo crime de insider trading.

Além da limitação da responsabilização penal em relação ao sujeito ativo do crime de uso indevido de informações privilegiadas, o Projeto de Lei do Senado $n^{\circ}$ 236/2012, que propõe a reforma do Código Penal, pretende trazer, ainda, uma segunda limitação, ao exigir a efetiva obtenção da vantagem para a configuração do delito, revogando o atual Art. 27-D da Lei n ${ }^{\circ} 6.385 / 76$.

$\mathrm{Na}$ doutrina, já há posição, defendida, dentre outros, por CARVALHOSA e EIZIRIK ${ }^{195}$, no sentido de que não obstante a inexistência de exigência expressa da obtenção de vantagem, o crime previsto no Art. 27-D é crime material, que se consuma com a produção do resultado danoso, sob o argumento de que a pena aplicável exige a cumulação da pena de reclusão com a pena de multa calculada em função da vantagem obtida.

Em sentido diametralmente oposto, PROENÇA defende que o crime de insider trading

[...] se trata de um delito de natureza formal, ou seja, consumado com a agressão ao bem jurídico protegido, no caso, a confiabilidade e, por corolário, a eficiência do mercado, sem se cogitar da efetiva obtenção de vantagem pretendida pelo agente, ou da lesão dos investidores que com ele negociaram em posição desvantajosa. ${ }^{196}$

\footnotetext{
${ }^{192}$ EIZIRIK, Nelson Laks; GAAL, Ariádna B.; PARENTE, Flávia; HENRIQUES, Marcus de Freitas. Mercado de Capitais - regime jurídico. 2. ed. (revisada e atualizada). Rio de Janeiro: Renovar, 2008. p. 545.

${ }^{193}$ BITENCOURT, Cezar Roberto; e BREDA, Juliano. Crimes contra o Sistema Financeiro Nacional \& contra o Mercado de Capitais. Rio de Janeiro: Lumen Juris, 2010. p. 358-359.

${ }^{194}$ CASTELLAR, João Carlos. Insider Trading e os Novos Crimes Corporativos. Rio de Janeiro: Ed. Lumen Juris, 2008. p. 120.

${ }^{195}$ CARVALHOSA, Modesto; EIZIRIK, Nelson Laks. A Nova Lei das S.A. São Paulo: Saraiva, 2002. p. 548-549.

${ }^{196}$ PROENÇA, José Marcelo Martins. Insider Trading. Regime jurídico do uso de informações privilegiadas no mercado de capitais. São Paulo: Ed. Quartier Latin, 2005. p. 342.
} 
Adotando a posição daqueles que entendem ser o crime de insider trading crime material, o Art. 367 do Projeto de Lei do Senado n 236/2012 prevê o seguinte:

Art. 367. Utilizar informação relevante, ainda não divulgada ao mercado, de que tenha conhecimento e da qual deva manter sigilo, ou deixar de repassar informação nos termos fixados pela autoridade competente, que, de qualquer forma, propicie, para si ou para outrem, vantagem indevida, mediante negociação, em nome próprio ou de terceiro, com valores mobiliários:

Pena - prisão, de dois a cinco anos. (grifos nossos)

Lançando críticas sobre a redação do Art. 367 do Projeto de Lei do Senado $\mathrm{n}^{\circ}$ 236/2012, a procuradora da CVM, Julya Sotto Mayor Wellisch aduziu:

Justamente porque a finalidade da proibição é assegurar um mercado transparente, simetricamente informado e confiável, é irrelevante para a caracterização do crime que a vantagem almejada pelo insider não seja obtida em razão, por exemplo, de condições de mercado desfavoráveis.

$\mathrm{O}$ anteprojeto, contudo, retrocede mais uma vez quando transforma o insider trading em ilícito de cunho material (e não formal), ignorando, assim, as razões que fundamentam a própria existência do crime.

A simples negociação de valores mobiliários com base em informações privilegiadas é capaz de transgredir os mais caros valores fundamentais à própria existência do mercado de capitais. Como já se disse, o sistema de mercado só funciona se houver confiança nas regras do jogo e na conduta dos jogadores.

Além disso, também foi excluída a pena de multa, consequência que nos parece essencial para efetiva repressão de crimes financeiros; e criminalizada conduta que, data venia, não mereceria tratamento penal.

Ao incluir no tipo a conduta daquele que deixa "de repassar informação nos termos fixados pela autoridade competente" criminalizou-se, por exemplo, a conduta omissiva do Diretório de Relações com os Investidores (DRI) que, na forma da Instrução CVM 358/02, não divulgar tempestivamente Fato Relevante. Tal conduta não parece suscetível de tratamento penal, bastando, para a sua adequada repressão, a atuação da CVM. ${ }^{197}$

Em matéria publicada na revista Capital Aberto de 2 de agosto de 2012,

José Alexandre Tavares Guerreiro também criticou a proposta, afirmando que

197 WELLISCH, Julya Sotto Mayor. Novo Código Penal e o Mercado de Capitais. Jornal Valor Econômico, São Paulo, p. 12, 23 jul. 2012. 
"essa interpretação privatista é um tremendo retrocesso". O Procurador Regional da República, Sady D’Assumpção Torres Filho acrescenta que considerar o insider trading um ato ilícito material desconstruiria toda a jurisprudência criada com a condenação de executivos ligados à Sadia, por exemplo, a primeira a ocorrer na esfera criminal. Mauro César Bullara Arjona também acredita que, para uma maior proteção da integridade do mercado, o ideal é manter o uso indevido de informação privilegiada como crime formal.

Críticas à parte, fato é que caso o Projeto seja aprovado em sua atual redação, a responsabilização pelo crime de insider trading passará a depender, por expressa disposição legal, da obtenção de vantagem. Além disso, o dispositivo acima transcrito exclui a pena de multa prevendo somente a pena de prisão, de dois a cinco anos.

\subsubsection{Independência das sanções e o princípio do non bis in idem}

Conforme já referido no item 4.6.2 supra, o Art. $9^{\circ}, \mathrm{V}$ da Lei $\mathrm{n}^{\circ}$ 6.385/76, confere à CVM poder para apurar, mediante processo administrativo, infrações à (i) Lei $n^{\circ}$ 6.385/76; (ii) Lei $n^{\circ}$ 6.404/76; (iii) Instruções e demais normativos expedidos pela CVM; e (iv) outras normas legais cujo cumprimento incumba à CVM fiscalizar.

O inciso VI do mencionado dispositivo prevê que a CVM poderá "aplicar aos autores das infrações indicadas no inciso anterior as penalidades previstas no Art. 11, sem prejuízo da responsabilidade civil ou penal.”

Logo, a eventual responsabilização administrativa de uma pessoa que se utiliza de informações privilegiadas não exclui sua responsabilidade civil e penal.

De fato, TAVARES GUERREIRO observa que 
[...] ao direito disciplinar não repugna o bis in idem. O princípio da não cumulatividade das penas é próprio e específico do direito criminal, cujas sanções atingem o indivíduo no seu status libertatis, o que, sem dúvida, pressupõe maior rigor jurídico na apreciação das condutas puníveis e, consequentemente, a consideração unitária da pena.

\section{E assevera:}

A atividade punitiva do Estado é uma, ao passo que as ordenações disciplinares se multiplicam. Enquanto a persecutio criminis corresponde a um interesse prevalente sobre todos os demais, encontrando sua limitação apenas no ius libertatis do cidadão, a sanção administrativa se fundamenta em interesses setoriais do Estado e não atinge bens jurídicos individuais de tão extremo valor.

Daí ter Amilcar de Araújo Falcão afirmado, com convicção, que o direito disciplinar desconhece o ne bis in idem. A assertiva, confirmada pela melhor doutrina brasileira e estrangeira parece-nos válida quer quanto à possibilidade do cúmulo de sanções penais e administrativas, quer, a fortiori, quanto à licitude de coexistência de sanções disciplinares emandas de diferentes órgãos estatais, em funções de interesses jurídicos diferenciados, na ordem positiva. ${ }^{198}$

Não se quer dizer que na esfera do direito administrativo sancionador,

possa uma pessoa ser processada duas vezes pela mesma infração. Ao contrário, CRETELLA JR. ressalta que

[...] o regime jurídico do non bis in idem em virtude do qual ninguém pode ser processado e punido duas vezes pela mesma infração, encontra plena aplicação em matéria disciplinar, considerando-se ambos os campos como absolutamente distintos. Isto é [o administrador] que cometeu a mesma falta ou crime não pode sofrer duas penas disciplinares ou duas criminais, o que não significa que não possa sofrer acumuladamente, uma pena disciplinar e outra pena criminal, respondendo também a dois processos distintos. ${ }^{199}$

\section{Abordando a influência da jurisdição administrativa nas jurisdições civil}

\section{e penal do insider trading, PARENTE esclarece:}

No que tange à jurisdição administrativa, inquérito e processo administrativo CVM, por exemplo, que nos interessa mais de perto, esta jurisdição, embora de categoria diversa das civil e penal, tem plena liberdade em relação àquelas.

A instância administrativa pode aceitar fatos e circunstâncias apurados em outra jurisdição, mas dar-lhes a sua própria interpretação. É-lhe vedado, no entanto,

\footnotetext{
${ }^{198}$ GUERREIRO, José Alexandre Tavares. Sobre o poder disciplinar da CVM. Revista de Direito Mercantil, Industrial, Econômico e Financeiro. São Paulo: n 43, ano XX, 1981. p. 69-70.

199 JÚNIOR, José Cretella. Prática do Processo Administrativo. São Paulo: Revista dos Tribunais, 1989. p. 76.
} 
declarar existentes fatos negados em outras jurisdições, ou penalizar quem foi declarado estranho ao fato. Nada impede no entanto que, na esfera de sua competência, decida no âmbito restrito de suas atribuições. Suas decisões não são definitivas, pelo art. 153, § $4^{\circ}$, da Constituição Federal [atual Art. $5^{\circ}$, XXXV da Constituição Federal de 1988], o que quer dizer que, embora finais e irrecorríveis na área administrativa, são possíveis de contestação na esfera judicial. ${ }^{200}$

Em sentido semelhante, EIZIRIK observa que essa independência entre as instâncias civil, administrativa e penal é relativa, dada a necessária unidade do sistema jurídico. Assim, observa o autor, "se determinado fato constitui ilícito administrativo e penal, a decisão final do juízo criminal declarando inexistente o fato ou que o acusado não foi o seu autor é válida na instância administrativa, a qual fica, no caso, vinculada à decisão judicial", ${ }^{201}$

Conclui-se, assim, que nada impede que, uma vez condenada em âmbito administrativo pela prática de insider trading, a mesma pessoa venha a ser responsabilizada na esfera civil, mediante o pagamento de perdas e danos aos eventuais prejudicados, e na esfera criminal, podendo ser condenada a pena de prisão e pagamento de multa.

\footnotetext{
200 PARENTE, Norma. Aspectos Jurídicos do “Insider Trading”. CVM. Superintendência Jurídica, Junho de 1978. p. 23..

${ }^{201}$ EIZIRIK, Nelson Laks; GAAL, Ariádna B.; PARENTE, Flávia; HENRIQUES, Marcus de Freitas. Mercado de Capitais - regime jurídico. 2. ed. (revisada e atualizada). Rio de Janeiro: Renovar, 2008. p. 307. O mesmo autor observa que o contrário - isto é, a decisão administrativa vincular a decisão penal - também pode ocorrer, conforme ficou decidido no Habeas Corpus $\mathrm{n}^{\circ}$ 83.674, julgado pelo Supremo Tribunal Federal em 16.03.2004, tendo como relator o Ministro Carlos Velloso: "Penal Processual Penal. Habeas Corpus. Crime contra o sistema financeiro nacional. Representação. Denúncia. Processo Administrativo. Arquivamento. Ação Penal: trancamento: falta de justa causa. I No caso, tendo a denúncia se fundado exclusivamente em representação do Banco Central, não há como dar curso à persecução criminal que acusa o paciente de realizar atividade privativa de instituição financeira, se a decisão proferida na esfera administrativa afirma que ele não pratica tal atividade. Inocorrência, portanto, de justa causa para o prosseguimento da ação penal contra o paciente. II. - HC deferido".
} 


\section{CAPÍTULO 5 - CONSTRUÇÕES DOUTRINÁRIAS E A POSIÇÃO DA CVM}

Desde o surgimento das primeiras regras tratando do insider trading no Brasil, tanto a doutrina quanto a CVM passaram a delinear determinados contornos jurídicos e consolidar entendimentos a respeito da negociação com base em informações privilegiadas.

Estas construções doutrinárias e jurisprudenciais foram se aperfeiçoando ao longo dos anos e passaram a complementar os dispositivos legais referentes ao insider trading. Foi a partir destas construções, muitas delas inspiradas nas lições dos autores e tribunais norte-americanos, que surgiram conceitos como o "insider primário" e "insider de mercado" - ou "tipper" e "tippee" -, e discussões como a possibilidade de condenação com base em indícios e a presunção de culpa dos administradores em casos envolvendo o uso de informações privilegiadas.

Assim, e tendo em vista que até os dias de hoje os conceitos e discussões desenvolvidos pela doutrina e pela CVM são constantemente utilizados na análise dos casos envolvendo a negociação com base em informações privilegiadas, serão abordadas neste capítulo as principais construções desenvolvidas pela doutrina e pela CVM a respeito do insider trading.

\subsection{O que é informação privilegiada?}

As normas de caráter repressivo ao insider trading abordadas no Capítulo 4 têm em comum o fato de proibirem a negociação de valores mobiliários por pessoas que tenham tido acesso a informações privilegiadas. 
Logo, deve-se buscar junto à doutrina e aos precedentes da CVM o que pode ser considerada uma informação privilegiada para fins de configuração do insider trading.

Antes, porém, de abordar esta questão, julga-se de extrema utilidade para a compreensão do sentido econômico do termo "informação privilegiada" o estudo, ainda que de forma breve, da classificação oferecida por Manne, que divide tais informações em duas categorias.

5.1.1. O conceito de "informação privilegiada" proposto por Henry G. Manne

De acordo com MANNE ${ }^{202}$, as informações necessárias para uma negociação bem sucedida no mercado de capitais podem ser divididas em duas grandes categorias. A primeira categoria compreenderia o que se pode chamar de sofisticação financeira ("financial sophistication"), e a segunda categoria compreenderia pedaços específicos de informações representando notícias sobre mudanças no cenário atual.

As informações da primeira categoria podem ser comparadas com o conhecimento a respeito de um sistema estático e sem modificações. Seu conteúdo representa simplesmente o conhecimento de todos os eventos relevantes do passado ${ }^{203}$. Logicamente, é possível que haja diferentes opiniões quanto ao significado ou mesmo quanto à ocorrência de eventos passados, mas todo tipo de informação que se encontra de alguma forma disponível se encaixa nessa primeira categoria.

\footnotetext{
${ }^{202}$ MANNE, Henry G., Insider Trading and the Stock Market. New York: Free Press, 1966. p. 48-57.

${ }^{203}$ Neste ponto, as informações de primeira categoria poderiam ser equiparadas a um balanço que reflete todos os eventos financeiros passados. Já as informações de segunda categoria, seguindo a mesma analogia, representariam eventos que causariam uma mudança no ativo ou passivo de um balanço existente.
} 
Já as informações da segunda categoria refletem as mudanças. São informações que, em um cenário realista, não podem ser previstas com antecedência, mesmo em nível de mera probabilidade. Na medida em que um determinado pedaço de informação possa ser previsto, seu valor está ligado às informações de primeira categoria, não de segunda. Em todo caso, como se verá adiante, nenhum dos dois tipos de informação pode ser explorado com sucesso sem o outro.

Dentro da primeira categoria, diferentes níveis de informação devem ser considerados. O nível mais fundamental inclui o conhecimento sobre a existência e natureza do próprio mercado de capitais, formas alternativas de investimento, como se relacionar com os intermediários financeiros, como circunstâncias específicas podem afetar diferentes tipos de investimento ou políticas financeiras, as várias consequências tributárias decorrentes de diferentes escolhas e, finalmente, a mecânica institucional básica da economia.

Um nível mais sofisticado de informações na primeira categoria está relacionado ao conhecimento da maneira como eventos específicos que podem ocorrer no mundo afetam o mercado de capitais. A título de exemplo, pode-se incluir neste nível da primeira categoria o conhecimento de como os seguintes eventos poderiam afetar o mercado de capitais: mudança na política de juros pelo Banco Central, seja restringindo ou expandindo a oferta de crédito; mudança na legislação tributária, afetando, por exemplo, o tratamento dado ao ganho de capital; acontecimentos internacionais que afetem tanto a oferta quanto a demanda de determinadas commodities.

No nível seguinte, os participantes do mercado seriam capazes de compreender como as diversas mudanças, como as citadas acima, afetariam não só o mercado de capitais como um todo, mas determinados setores e companhias. 
As informações mais básicas podem ser adquiridas simplesmente pagando os custos de uma universidade ou lendo livros e jornais. No entanto, o conhecimento sofisticado a respeito de uma indústria ou uma companhia específica não é tão facilmente adquirido quanto os níveis mais baixos da primeira categoria. Ao contrário, este nível de conhecimento é tipicamente adquirido como uma consequência da atuação profissional dentro de determinada indústria ou companhia.

Note-se que as informações dos níveis mais altos da primeira categoria não são escondidas ou confidenciais, mas a sofisticação completa sobre um determinado setor estará particularmente disponível para aqueles nele inseridos e raramente para aqueles que estão fora ${ }^{204}$.

As informações de primeira categoria podem ser obtidas de diversas maneiras, inclusive como consequência de um contrato de trabalho ${ }^{205}$. Analistas de investimento, por exemplo, trabalham adquirindo este tipo de informação para 113onside-la a seus clientes ${ }^{206}$. De todo modo, informações de primeira categoria a respeito de uma indústria ou companhia não podem ser genericamente consideradas informações privilegiadas.

\footnotetext{
${ }^{204}$ Esta afirmação é ainda mais verdadeira para companhias específicas do que para setores inteiros. Por exemplo, o conhecimento de que a demanda por aço aumentou poderá ser explorada comprando-se ações de todas as companhias do setor siderúrgico, mesmo que algumas companhias específicas não participem dos ganhos, talvez porque, diferentemente de outras companhias, elas já estão operando com sua capacidade máxima.

${ }^{205}$ Neste aspecto, as informações adquiridas por conta de cargo profissional podem se assemelhar à verdadeira informação privilegiada. No entanto, a mera experiência e sofisticação adquiridas em razão do emprego, exceto por segredos comerciais, não deveriam impedir o empregado de usá-las para negociar ações no mercado.

${ }^{206}$ O caso SEC v. Capital Gains Research Bureau, Inc. envolveu justamente a discussão sobre utilização de informações de primeira categoria por analistas de investimento. Em resumo, a Capital Gains Research Bureau, Inc., foi uma empresa de análise de investimentos que se envolveu na prática conhecida como scalping. A firma de investimentos adquiriu ações de uma companhia aberta para sua própria conta logo antes de recomendar a mesma ação para seus clientes sem divulgar o suposto conflito de interesses, revendendo as ações em seguida. Para uma análise crítica do caso, confira-se MANNE, Henry G., Insider Trading and the Stock Market. New York: Free Press, 1966. p. 50-54.
} 
Passando para as informações de segunda categoria, $\mathrm{MANNE}^{207}$ explica que tais informações representariam o conhecimento sobre eventos específicos ou sobre a probabilidade de ocorrência de eventos futuros que possam efetivamente afetar o preço das ações.

No entanto, tais informações não necessariamente serão privilegiadas, conforme exemplo trazido por MANNE:

For example, a disclosure in the newspapers that the government is about to step up procurement of aircraft represents a change from previous condition. This is a specific bit of information which, if properly understood, has a value in the marketplace. But it cannot be considered inside information if it is publicized to all interested parties before it is acted upon in the stock market [...]. Non-inside, second category information might typically include news of such matters as government financial, tax, and credit policies, changes in the general market demand for a specific product, nationalization of foreign holdings by proclamation, loss of an important plant or building as a result of fire or natural causes, and other matters that in the ordinary course of events can be known to outsiders just as quickly as they will be known to officials within affected industries or companies. ${ }^{208}$

De acordo com referido autor, para que as informações de segunda categoria constituam verdadeira informação privilegiada, duas condições devem estar presentes: em primeiro lugar, o evento deve ser capaz de, mantidos todos os demais fatores constantes, afetar substancialmente o preço das ações de uma determinada companhia. Além disso, as informações precisam ter a capacidade de "exploração física" ("physical exploitation") por um ou mais indivíduos antes de divulgadas ao público, isto é, deve haver a real possibilidade de uma pessoa ou grupo de pessoas comprar ou vender as ações ou outros valores mobiliários antes que o efeito da nova informação seja refletido no mercado.

Esta classificação trazida por Manne deixa claro que mesmo em um mercado onde todas as informações relevantes - seja de primeira ou segunda categoria - são prontamente divulgadas, a simetria informacional dificilmente

\footnotetext{
${ }^{207}$ MANNE, Henry G., Insider Trading and the Stock Market. New York: Free Press, 1966. p. 54.

${ }^{208}$ Ibid. p. 54
} 
será alcançada de forma plena. Como visto, mesmo as informações da primeira categoria, disponíveis a todos os investidores, são aproveitadas de formas diferentes pelos diversos participantes do mercado.

Não obstante, ainda que o conceito de informação relevante seja extremamente frágil do ponto de vista da sua real contribuição para o processo de equalização do nível informacional no mercado, a doutrina brasileira e os precedentes da CVM passaram a delinear ao longo dos anos os contornos daquilo que poderia ser considerado como uma informação relevante, visando dar mais segurança aos investidores e às próprias companhias abertas sujeitas ao regime do full and fair disclosure.

\subsubsection{O entendimento da doutrina brasileira e da CVM}

De acordo com o ex-diretor da CVM, Nelson Eizirik, em voto proferido no âmbito do Inquérito Administrativo CVM n 2/85, julgado em 11.11.1986, também conhecido como Caso Acrinor, "[o] elemento fundamental para a caracterização do 'insider trading' é a utilização, pelo 'insider', de uma informação confidencial sobre fato relevante, de seu conhecimento exclusivo".

O parágrafo $1^{\circ}$ do Art. 155 e o $\S^{\circ}$ do Art. 157 da Lei $n^{\circ}$ 6.404/76 trouxeram, pela primeira vez, a ideia de fato relevante, qual seja, aquele fato capaz de "influir de modo ponderável na cotação de valores mobiliários" e de "influir, de modo ponderável, na decisão dos investidores do mercado de vender ou comprar valores mobiliários emitidos pela companhia". Este conceito mostrou-se extremamente aberto na prática, o que possibilitou que a CVM, principalmente antes da edição das normas regulamentares que trataram da divulgação de informações, como a Instrução CVM n 31/84 e 358/02, conferisse ao dispositivo supracitado maior concretude. 
Neste contexto, vale conferir trecho do voto do ex-diretor da CVM Jorge Hilário Gouvêa Vieira, no âmbito do Inquérito Administrativo CVM n ${ }^{\circ}$ 1/78, julgado em 02.02.1979 (Caso Servix), o primeiro caso de insider trading julgado pela Autarquia:

À administração da companhia cabe exercer um julgamento de valor acerca da relevância dos fatos que ocorreram ou poderão ocorrer e que terão impacto considerável nos seus negócios, com a finalidade de divulga-los publicamente. O principal critério de decisão é baseado na avaliação da probabilidade de a informação vir a influir de modo ponderável na decisão dos investidores do mercado de vender ou comprar valores mobiliários emitidos pela companhia. Na verdade, cumpre ao administrador se posicionar como se investidor fosse, e avaliar se a informação afetaria a sua decisão em vender, comprar ou permanecer com suas ações.

Na doutrina, EIZIRIK explica que em nosso ordenamento jurídico,

[...] a exemplo do que ocorre nos Estados Unidos e nos países da União Europeia, o conceito de fato relevante pode abranger qualquer evento que, potencialmente, acarrete efeitos significativos sobre as negociações com valores mobiliários emitidos pela companhia, independentemente de estar previsto em norma legal ou regulamentar que relacione os fatos que devam ser obrigatoriamente divulgados. ${ }^{209}$

Atualmente, o conceito de ato ou fato relevante encontra-se regulamentado de forma mais detalhada pelo Art. $2^{\circ}$ da Instrução CVM ${ }^{\circ}$ $358 / 02^{210}$, que trouxe em seu parágrafo único, ainda, uma lista não taxativa com 22 (vinte e dois exemplos) de atos ou fatos considerados relevantes para os fins da mencionada Instrução.

EIZIRIK adverte, porém, que "o critério fundamental para configurar um fato relevante [...] não consiste na mera verificação se ele está incluído na

\footnotetext{
${ }^{209}$ EIZIRIK, Nelson Laks; GAAL, Ariádna B.; PARENTE, Flávia; HENRIQUES, Marcus de Freitas. Mercado de Capitais - regime jurídico. 2. ed. (revisada e atualizada). Rio de Janeiro: Renovar, 2008. p. 541.

${ }^{210}$ Art. $2^{-}$Considera-se relevante, para os efeitos desta Instrução, qualquer decisão de acionista controlador, deliberação da assembleia geral ou dos órgãos de administração da companhia aberta, ou qualquer outro ato ou fato de caráter político-administrativo, técnico, negocial ou econômicofinanceiro ocorrido ou relacionado aos seus negócios que possa influir de modo ponderável:

I - na cotação dos valores mobiliários de emissão da companhia aberta ou a eles referenciados;

II - na decisão dos investidores de comprar, vender ou manter aqueles valores mobiliários;

III - na decisão dos investidores de exercer quaisquer direitos inerentes à condição de titular de valores mobiliários emitidos pela companhia ou a eles referenciados.
} 
relação exemplificativa da Instrução $C V M n^{\circ} 358 / 2002 " 211$, mas sim em saber se ele é capaz de produzir as consequências previstas nos incisos do caput do Art. $2^{\circ}$ do referido normativo.

Assim, continua o autor, "fatos não relacionados podem ser relevantes, devendo ser objeto de divulgação; por outro lado, exemplos de fatos relevantes mencionados na referida Instrução podem, diante do caso concreto, não merecerem tal qualificação, não sendo necessária a sua divulgação". 212

No entanto, para que uma informação seja considerada privilegiada para fins da configuração do insider trading, não basta que ela seja relevante. É preciso, também, que a informação em questão seja sigilosa ${ }^{213}$. Neste ponto, a ex-diretora da CVM, Norma Parente, aduziu:

Quanto ao sigilo, são menores as dificuldades em caracterizá-lo. Haverá sigilo quando a informação não puder ser obtida por meios acessíveis ao público em geral. Via de regra, a informação deixará de ser sigilosa através da publicação imediata que deve ser promovida pelos administradores. Contudo, se por qualquer outra razão ela vier a perder seu caráter confidencial, já não se prestará ao insider trading. A informação disseminada, ainda que de forma irregular e por mais relevante que seja, já será uma informação de mercado, que, portanto, presume-se refletida nas expectativas dos agentes que negociam valores mobiliários.

\section{$[\ldots]$}

Desse modo, sendo a informação de domínio público, não há como 117onsidera-la privilegiada e, por consequência, é impossível cogitar acerca do suposto uso indevido desta informação. (PAS CVM n ${ }^{\circ}$ 06/2003, j. 14.09.2005. Voto da Diretora Norma Parente)

${ }^{211}$ EIZIRIK, Nelson Laks; GAAL, Ariádna B.; PARENTE, Flávia; HENRIQUES, Marcus de Freitas. Mercado de Capitais - regime jurídico. 2. ed. (revisada e atualizada). Rio de Janeiro: Renovar, 2008. p. 541.

212 Ibid. p. 541.

${ }^{213}$ Note-se que além da relevância e confidencialidade da informação, alguns autores, como Nelson Eizirik apontam, ainda, outros elementos necessários para que uma informação possa ser considerada privilegiada, a saber, (i) ser razoavelmente precisa, isto é, referente a um fato, e não somente a rumores ou boatos, devendo apresentar um mínimo de materialidade ou objetividade, permitindo sua utilização por um investidor médio; e (ii) ser relativa a valores mobiliários ou a seus emissores (in EIZIRIK, Nelson Laks; GAAL, Ariádna B.; PARENTE, Flávia; HENRIQUES, Marcus de Freitas. Mercado de Capitais - regime jurídico. 2. ed. (revisada e atualizada). Rio de Janeiro: Renovar, 2008. p. 543). Como visto, estes requisitos adicionais já haviam sido tratados por Henry G. Manne em 1966, quando o mesmo se referia a informações capazes de serem "fisicamente exploradas" e referentes à companhia e seus valores mobiliários, e não ao mercado ou a conjuntura econômica como um todo. 
Portanto, sendo a informação sobre determinada companhia aberta relevante e sigilosa, não podem os administradores ou terceiros que a ela tiveram acesso negociar com valores mobiliários de sua emissão antes da divulgação da informação ao público.

\subsection{Insiders primários e secundários e os elementos caracterizadores do insider trading}

Conforme já adiantado no item 4.2.2 do presente trabalho, os insiders podem ser, basicamente, (i) pessoas que, por força de algum relacionamento mantido com a companhia, têm acesso a informações privilegiadas, isto é, informações relevantes e sigilosas; e (ii) terceiros que, apesar de não manterem relacionamento direto com a companhia, tomam conhecimento de informações privilegiadas a seu respeito.

Ao longo dos anos, a doutrina brasileira e a jurisprudência administrativa da CVM, inspirados no direito norte-americano, passaram a adotar a classificação que divide os insiders em dois grandes grupos, nomeadamente os "insiders primários" e "insiders secundários". Neste ponto, vale conferir a explicação de EIZIRIK ${ }^{214}$ :

Os "insiders primários" ou "institucionais" são aqueles que detêm acesso a informação privilegiada em razão de sua condição de acionistas controladores, pelo fato de ocuparem cargo de administração, ou ainda no exercício de uma função, mesmo pública, de uma profissão ou de um ofício, ainda que temporário, que lhes permita o acesso direto a uma informação privilegiada. São as pessoas que recebem, diretamente, a informação privilegiada de sua fonte e têm o conhecimento especializado suficiente para saber que tal informação é relevante.

Já os "insiders secundários" (tippees) são aqueles que recebem a informação privilegiada, direta ou indiretamente dos "insiders primários" e não estão obrigados ao dever de sigilo e nem necessariamente sabem que se trata de uma informação privilegiada.

\footnotetext{
${ }^{214}$ EIZIRIK, Nelson Laks; GAAL, Ariádna B.; PARENTE, Flávia; HENRIQUES, Marcus de Freitas. Mercado de Capitais - regime jurídico. 2. ed. (revisada e atualizada). Rio de Janeiro: Renovar, 2008. p. 545.
} 
Conforme observado pela IOSCO, há uma tendência mundial no sentido de incluir na categoria de insiders primários terceiros que prestam serviços à companhia, tais como consultores, auditores e advogados, que acabam tendo, ainda que temporariamente, acesso direto a informações sensíveis e sigilosas:

Definitions of "primary insider" generally include members of management and the supervisory or administrative bodies of the issuer. This definition is sometimes expanded to include employees of the company and those who provide services to the issuer (including outside lawyers, accountants and financial advisers).

$[\ldots]$

The concept of primary insiders under US regulations relates to the fiduciary duty of particular persons to the relevant corporation, such as officers, directors, and employees. However, such a fiduciary duty can be "acquired" by persons who provide services to the corporation, like outside lawyers, consultants, investment bankers or others (so called "temporary" or "constructive" insiders (see section 1.2.1.1.), provided the corporation expects them to keep the information confidential. Definitions of "primary insider" should encompass the officers in the company generating the inside information, as well as any outside professional service providers having access to inside information. In jurisdictions where the employees of the securities regulator have access to inside information, they should be included within this definition. To facilitate the enforcement of insider trading regulations, a primary insider should have the burden of proof to negate a presumption that he had knowledge of inside information. ${ }^{215}$

Tal tendência acabou por gerar uma discussão relativa à amplitude do termo "qualquer pessoa", previsto no $\S 4^{\circ}$ do Art. 155 da Lei n 6.404/76. De acordo com referido dispositivo, é "vedada a utilização de informação relevante ainda não divulgada, por qualquer pessoa que a ela tenha tido acesso, com a finalidade de auferir vantagem, para si ou para outrem, no mercado de valores mobiliários" (grifado).

Para EIZIRIK e CARVALHOSA, a expressão "qualquer pessoa" deve ser interpretada restritivamente:

${ }^{215}$ IOSCO (2003). Insider Trading - How Jurisdictions Regulate It. Disponível em www.iosco.org. 
Será considerada insider qualquer pessoa que, em decorrência do exercício de funções na sociedade ou no mercado ou mesmo por circunstâncias especiais de acesso à administração da companhia, venha a deter, antes dos demais acionistas, investidores ou agentes operadores do mercado de capitais, informações relevantes relativas aos negócios e ao estado da companhia. Há, no entanto, um limite para o termo "qualquer pessoa" utilizado na norma em estudo. Com efeito, deve haver um nexo profissional entre o vazamento das informações e os terceiros, para que estes possam ser considerados tippees. Assim, apenas aqueles que em virtude do exercício de profissão tenham acesso a essas informações (advogados, auditores, operadores de mercado, peritos etc.) é que serão responsabilizáveis pelo uso dessas informações. ${ }^{216}$

PROENÇA, por outro lado, analisando especificamente o posicionamento de Eizirik e Carvalhosa, sustenta entendimento diverso:

Para contestar esse entendimento basta atentar para as regras emanadas do poder normativo concedido à CVM, cujo teor já alcançara a meta perseguida pela reforma consubstanciada na Lei 10.303/2001. Com efeito, a introdução do novo parágrafo, ao nosso ver, visou, especificamente, a vedar a "qualquer pessoa", sem qualquer limitação, a utilização de informações privilegiadas no mercado de capitais, até porque a base da legislação não é mais societária, mas sim relativa a valores mobiliários, como discutido anteriormente. $\mathrm{O}$ dever de lealdade restringe-se aos administradores, mas qualquer outra pessoa sujeita-se às normas repressivas da prática de insider trading, quer as de natureza civil, quer as de ordem penal. Repisese que a questão é pública, de interesse do povo, nos termos do art. $3^{\circ}$, II, da CF. ${ }^{217}$

No entanto, conforme bem observado por TRINDADE, "a polêmica, na prática, tem repercussão limitada". De acordo com referido autor,

[...] os casos concretos de investigação e repressão pela CVM normalmente envolverão pessoas com algum nível de ligação com o emissor dos valores mobiliários, porque será praticamente impossível identificar e provar ilicitude na conduta de outros agentes. Por outro lado, qualquer que seja a interpretação do conceito de "qualquer pessoa" adotado pela lei, é induvidoso que, com a reforma da lei, a definição de insider passou a abranger as pessoas que recebem a informação por meio de relação profissional ou comercial com o emissor dos valores mobiliários. ${ }^{218}$

Existem diversas justificativas para a divisão dos insiders em duas categorias, conforme explicitado pela IOSCO:

${ }^{216}$ CARVALHOSA, Modesto e EIZIRIK, Nelson. A Nova Lei das S/A. São Paulo: Saraiva, 2002. p. 322-323.

217 PROENÇA, José Marcelo Martins. Insider Trading. Regime jurídico do uso de informações privilegiadas no mercado de capitais. São Paulo: Ed. Quartier Latin, 2005. p. 293.

${ }_{218}$ TRINDADE, Marcelo Fernandez. Vedações à Negociação de Valores Mobiliários por Norma Regulamentar: Interpretação e Legalidade. Temas de Direito Societário Empresarial Contemporâneos. São Paulo: Malheiros, 2011. p. 455-456. 
In definitions of insiders, a distinction is usually drawn between two categories of insiders: primary insiders and secondary ones. Such a distinction is justified for a number of reasons. First, primary insiders get information from its source and have the necessary knowledge to assess the materiality of the information. Secondly, they are expected to understand the consequences of trading on confidential information. Hence, the sanctions imposed on primary insiders are usually much harsher than those imposed on secondary ones. ${ }^{219}$

No âmbito sancionador, esta classificação dos insiders em duas categorias possui uma série de implicações práticas. Conforme observado por TRINDADE $^{220}$, para a caracterização do tipo administrativo insider trading, o $\S 4^{\circ}$ do art. 155 da Lei ${ }^{\circ} 6.404 / 76$ exige a presença de quatro elementos: (i) a existência de uma "informação relevante ainda não divulgada" ao mercado; (ii) o "acesso" privilegiado a essa informação; (iii) a "utilização" dessa informação "no mercado de valores mobiliários"; e (iv) a "finalidade de auferir vantagem, para si ou para outrem".

Logo, na ausência de qualquer dos elementos acima mencionados, não estará configurado o tipo administrativo insider trading, não podendo haver, por conseguinte, qualquer sanção por parte da CVM.

Entretanto, com base na diferenciação entre insiders primários e secundários, alguns dos elementos exigidos pela Lei $\mathrm{n}^{\circ}$ 6.404/76 são presumidos - por construções jurisprudenciais e pelas normas da CVM - como estando presentes nos casos envolvendo os insiders primários, cabendo ao acusado o ônus de provar sua inexistência.

A primeira presunção que recai sobre este grupo de insiders é uma presunção iuris tantum de que, por força da posição que ocupam na companhia ou pela relação que mantém com pessoas a ela ligadas, os insiders primários tiveram acesso a informações relevantes e sigilosas, tornando a eventual

\footnotetext{
${ }^{219}$ IOSCO (2003). Insider Trading - How Jurisdictions Regulate It. Disponível em www.iosco.org.

220 TRINDADE, Marcelo Fernandez. Vedações à Negociação de Valores Mobiliários por Norma Regulamentar: Interpretação e Legalidade. Temas de Direito Societário Empresarial Contemporâneos. São Paulo: Malheiros, 2011. p. 457.
} 
negociação com valores mobiliários de emissão da companhia irregular. No entanto, quando a negociação com base em informações privilegiadas envolve um insider secundário (tippee), também chamado de insider de mercado, cabe à acusação provar seu acesso à informação.

Esta tem sido a posição pacífica adotada pela CVM, conforme se depreende do voto do ex-presidente da autarquia Marcelo Trindade, no âmbito do PAS CVM n ${ }^{\circ}$ 13/00, julgado em 17.04.2002:

Realmente, quando se trata da atuação de administradores da companhia, comprando ou vendendo ações no mercado ao tempo em que podem, por sua posição, ter conhecimento de fatos não divulgados ao público, passíveis de influenciar cotações, poder-se-ia presumir — presunção juris tantum — que a atuação seria irregular, bastando verificar-se a condição de administrador que tivesse conhecimento da informação aliada ao fato de ter negociado ações da empresa que administra em período em que houvesse fato não divulgado que pudesse influenciar as cotações dos papéis.

Entretanto, quando se trata de não administradores, tal presunção não pode merecer acolhida, no meu entendimento. Como se vê da decisão do Colegiado no IA 02/85, de que foi Relator o então Diretor Nelson Eizirik, na qual se estabeleceu que "tratandose de um 'insider de mercado', ou 'tippee', não ocorre tal presunção, cabendo à CVM provar seu acesso à informação”.

Aliás, o mesmo ilustre jurista já afirmara tal posição em artigo de 1983, dizendo: 'Tratando-se o 'insider' de administrador ou controlador da companhia, há uma presunção 'juris tantum' de que, dado o seu cargo, ele tivera acesso à informação relevante. Tratando-se, porém, de 'insider de mercado', cabe ao autor da ação ou à CVM provar que ele tivera acesso à informação relevante". ${ }^{221}$

A partir da análise dos precedentes da CVM, verifica-se, neste contexto, que a prova de acesso à informação por parte dos insiders secundários é questão das mais tormentosas. Isto porque, exceto pelos casos em que a

\footnotetext{
${ }^{221}$ Este posicionamento vem sendo adotado na quase totalidade dos casos de insider trading julgados pela CVM. Apenas a título de exemplo, confira-se os seguintes casos (i) voto do Diretor-Relator Nelson Eizirik, no âmbito do PAS CVM n ${ }^{\circ} 2 / 85$, j. 11.11.1986; (ii) voto do Diretor-Relator Wladimir Castelo Branco, no âmbito do PAS CVM n ${ }^{\circ}$ 17/02, j. 25.10.2005; (iii) voto do Diretor-Relator Sérgio Weguelin, no âmbito do PAS CVM n 2004/0852, j. 30.05.2006; (iv) voto do Diretor-Relator Marcelo Trindade, no âmbito do PAS CVM n ${ }^{\circ}$ 04/04, j. 28.06.2006; (v) voto do Diretor-Relator Sérgio Weguelin, no âmbito do PAS CVM n 2003/5669, j. 11.07.2006. Em voto proferido no âmbito do já mencionado PAS CVM n ${ }^{\circ} 13 / 00$, a ex-diretora Norma Parente adotou o entendimento oposto, isto é, de que a presunção de acesso à informação também poderia ser feita para os insiders de mercado, tendo sido, no entanto, voto vencido.
} 
acusação logra obter gravações telefônicas ou evidências claras de que houve vazamento de uma informação privilegiada, a prova de acesso a este tipo de informação costuma vir carregada de uma alta dose de subjetivismo, estando normalmente baseada em simples relações de amizade ou parentesco entre a pessoa que supostamente se utiliza da informação e aquela que tem acesso direto a ela.

Não por outro motivo, a CVM já absolveu, por mais de uma vez, acusados de insider trading pelo fato de não ter a acusação conseguido provar o efetivo acesso à informação. Veja-se, neste sentido, transcrição de alguns julgados:

Melhor sorte não assiste à segunda indicação de informação privilegiada vislumbrada pela Comissão, a saber, o fato de ser o Sr. Jakurski "pessoa bastante conhecida e relacionada no mercado" (fls. 4.012). Na verdade, tenho até dificuldade de rebater tal argumento do Relatório da Comissão de Inquérito, pois me parece de evidência solar que uma tal popularidade em nada pode incriminar uma pessoa em inquérito desta natureza.

$[\ldots]$

Quanto ao primeiro indício, os depoimentos foram unânimes ao afirmar serem aquelas pessoas primos, mas verem-se apenas ocasionalmente, no Natal, segundo o Sr. Sicupira, ou duas ou três vezes por ano, segundo o indiciado Otávio Ângelo.

Ao examinar esse primeiro suposto indício, fiz eu mesmo uma lista mental de todos os primos que tenho, e que encontro apenas no Natal, ou poucas vezes no ano, em um casamento, ou aniversário, ou pela rua, enfim.

Fiquei pensando, então, em que enrascada estão aqueles que, dentre esses parentes, negociem com ações, se prevalecer o entendimento adotado no Relatório da Comissão de Inquérito, pois têm eles um primo diretor da CVM - com seguido acesso a informações privilegiadas.

Não me parece minimamente razoável que se impute a alguém a posse de informação privilegiada por ser primo de um insider, especialmente quando essa relação de parentesco não é acompanhada de um contato frequente, e quando aquele que negocia as ações é pessoa de mercado, dono de várias empresas que compram e vendem ações com razoável constância, como está no Relatório.

$[\ldots]$

Em outras palavras: uma relação de parentesco tênue, e um pequeno lucro em uma operação compatível com os volumes normalmente operados pela empresa, não me 
parecem indício suficiente para sustentar acusação de insider trading. (PAS CVM n ${ }^{\circ}$ 13/00, j. 17.04.2002. Voto do Presidente Marcelo Trindade).

$* * * * *$

A Acusação entendeu que a existência de relações interpessoais dos sócios da 3G, exassociados da GP, com executivos e outros membros da equipe da GP seria um indício de detenção de informação privilegiada.

Segundo a Acusação, tanto Alexandre Behring como Alexandre Perez, executivos da $3 \mathrm{G}$, na condição de ex-executivos da GP, teriam relacionamento histórico e presente com Antonio Bonchristiano e outros membros da GP.

A existência de relações pessoais entre os envolvidos nas operações investigadas tem sido considerada pelo Colegiado da CVM como elemento adicional na apuração de ilícitos de uso indevido de informação privilegiada. Ela constitui, no geral, um indício adicional que lhe permite formar convicção sobre a possibilidade de acesso à informação relevante pelos acusados. Quando isoladamente considerada, no entanto, a existência de relações pessoais não é suficiente para comprovar a detenção de informação privilegiada.

É o que ocorre no presente caso. Com o afastamento dos demais indícios, entendo que a existência de relações entre pessoas que trabalharam juntas em algum momento e que participam do mesmo mercado seria insuficiente para comprovar que informações privilegiadas foram passadas pelos executivos da GP aos executivos da 3G. (PAS CVM n ${ }^{\circ}$ 11/09, j. 03.04.2012. Voto da Diretora Luciana Pires Dias)

Por outro lado, no Caso Bahema ${ }^{222}$, o Colegiado da CVM adotou, por maioria, o entendimento no sentido de que não obstante ser necessário provar o acesso à informação para se condenar um insider secundário pela utilização de informação privilegiada, tal prova não precisa necessariamente demonstrar a forma por meio da qual se obteve a informação relevante e sigilosa, nem tampouco identificar o tipper, ou seja, aquele que transmite a informação. Bastaria, assim, que a acusação apresentasse indícios fortes e convergentes que, somados as demais circunstâncias do caso, convencessem o julgador de que houve acesso à informação, por mais que toda a dinâmica para que isso ocorresse não fosse completamente demonstrada.

As duas outras presunções que recaem sobre os insiders primários decorrem da Instrução CVM n 358/02. Conforme se depreende da leitura do

${ }^{222}$ PAS CVM n 24/05, j. 07.10.2008. Para os argumentos tratando sobre a prova de acesso à informação, vide voto do Relator Sérgio Weguelin e do Diretor Marcos Pinto. 
caput e do $\S 1^{\circ}$ do Art. 13 da mencionada Instrução - que, como visto, regulamentaram, respectivamente os $\S \S 1^{\circ}$ e $4^{\circ}$ do Art. 155 da Lei ${ }^{\circ} 6.404 / 76$ - a norma expedida pela CVM, ao contrário dos quatro elementos previstos na norma regulamentada, exigiu a presença de somente dois para que se configurasse o insider trading, a saber: "(i) a existência de uma 'informação relevante ainda não divulgada' ao mercado; e (ii) o 'acesso' privilegiado e consciente a essa informação, por meio da companhia",223.

Em um primeiro momento, poder-se-ia pensar que a Instrução CVM n ${ }^{\circ}$ $358 / 02$, ao regulamentar a vedação legal, dispensando os outros dois requisitos exigidos pela Lei $\mathrm{n}^{\circ}$ 6.404/76 - quais sejam (i) a utilização da informação no mercado de valores mobiliários; e (ii) a finalidade de auferir vantagem para si ou para outrem. - teria restringido a aplicação da lei regulamentada.

No entanto, o que fez a Instrução CVM n ${ }^{\circ} 358 / 02$ foi tão somente estabelecer duas presunções relativas, quais sejam, a de que o insider primário, ao negociar com valores mobiliários de uma determinada companhia em relação à qual pode ser considerado um insider, se utiliza da informação privilegiada com a finalidade de auferir vantagem. Corroborando este entendimento, confiram-se as lições de TRINDADE:

A interpretação das vedações regulamentares como normas de presunção relativa é, como se disse, a única que se coaduna com a lei regulamentada. Qualquer outra interpretação permitiria que a norma regulamentar eliminasse o requisito subjetivo para a prática do insider trading ou vedasse a negociação em casos não previstos na própria lei. E, se isso ocorresse, estar-se-ia diante de patente ilegalidade, como explicam Hely Lopes Meirelles e Pontes de Miranda em passagens inequívocas acerca dos limites do regulamento. Para o festejado administrativista: "Como ato inferior à lei, o regulamento não pode contraria-la ou ir além do que ela permite. No que o regulamento infringir ou extravasar da lei, é írrito e nulo, por caracterizar situação de ilegalidade (...)". Esta também é a posição de Pontes de Miranda, para quem "onde se estabelecem, alteram ou extinguem direitos não há regulamentos - há abuso do poder regulamentar, invasão de competência legislativa. O regulamento não

\footnotetext{
223 TRINDADE, Marcelo Fernandez. Vedações à Negociação de Valores Mobiliários por Norma Regulamentar: Interpretação e Legalidade. Temas de Direito Societário Empresarial Contemporâneos. São Paulo: Malheiros, 2011. p. 458.
} 
é mais do que auxiliar das leis, auxiliar que sói pretender, não raro, o lugar delas, mas sem que possa, com tal desenvoltura, justificar-se e lograr que o elevem à categoria de lei". 224

Em voto proferido no âmbito do PAS CVM n 2010/4206, julgado em 23.08.2011, o ex-diretor da CVM Alexsandro Broedel, comentando o posicionamento adotado por Marcelo Trindade na obra acima transcrita, sustentou que a dispensa do requisito "finalidade de auferir vantagem" previsto na Lei $\mathrm{n}^{\circ}$ 6.404/76 para a configuração do insider trading fundamenta-se, ainda, em outro argumento:

No entanto, vou mais além, pois entendo que se pode justificar a opção da CVM de não inserir o elemento "finalidade de auferir vantagem", na edição do art.13 e parágrafos da Instrução CVM n ${ }^{\circ} 358 / 08$, por uma leitura muito mais simples, a saber: o referido art.13 não regulamenta o art.155 da Lei n ${ }^{\circ} 6.404 / 76$, exclusivamente.

Com efeito, logo em seu preâmbulo, a referida Instrução CVM no 358/02 aponta que o seu fundamento legal são os "artigos $4^{\circ}$ e seus incisos, $8^{\circ}$, incisos I e III, 18, inciso II, letra 'a', e 22, $\S 1^{\circ}$, incisos I, V e VI, da Lei $n^{\circ}$ 6.385, de 7 de dezembro de 1976, e no art. 157 da Lei n ${ }^{\circ} 6.404$, de 15 de dezembro de 1976".

Assim, conforme os dispositivos legais mencionados, a CVM deve exercer as suas atribuições para o fim de "assegurar o funcionamento eficiente e regular dos mercados da bolsa e de balcão" e "proteger os titulares de valores mobiliários e os investidores do mercado contra o uso de informação relevante não divulgada no mercado de valores mobiliários", entre outras (artigo $4^{\circ}$ e incisos, da Lei n ${ }^{\circ} 6.385 / 76$ ). Disso decorre a total competência da CVM para vedar determinadas operações no mercado, em determinadas condições, podendo, para tanto, definir "as espécies de operação autorizadas na bolsa e no mercado de balcão; e métodos e práticas que devem ser observados no mercado" (art.18, inciso II, alínea 'a', da Lei nº 6.385/76).

Em todo caso, a presunção relativa que recai sobre os insiders primários tem como consequência prática a inversão do ônus da prova, transferindo para

\footnotetext{
${ }^{224}$ Ibid. p. 463. Em sentido oposto entendem Alexandre Pinheiro dos Santos, Fábio Medina Osório e Julya Sotto Mayor Wellisch. Para tais autores, "a norma administrativa contempla uma proibição objetiva de negociar com valores mobiliários de emissão da companhia, ou a eles referenciados." E continuam, afirmando que "ao contrário do dispositivo legal - que faz menção à intenção do agente de obter vantagem indevida - a norma simplesmente veda que aqueles que tenham conhecimento de informação relativa a ato ou fato relevante negociem com papéis da companhia, ainda que se trate, por exemplo, de operação objetiva e manifestamente contrária à cotação do valor mobiliário. É irrelevante, portanto, a intenção de auferir vantagem para que se consume a violação ao caput do art. 13 da Instrução CVM n. 358/2002" (grifado). SANTOS, Alexandre Pinheiro dos; OSÓRIO, Fabio Medina; e WELLISCH, Julya Sotto Mayor. Mercado de Capitais - Regime Sancionador. São Paulo: Saraiva, 2012. p. 142.
} 
as pessoas que se inserem nesse grupo de insiders a tarefa de provar que (i) não tiveram acesso à informação privilegiada ${ }^{225}$; (ii) apesar de terem tido acesso, a negociação com valores mobiliários da companhia não foi influenciada por tal informação, ou seja, não utilizaram a informação ${ }^{226}$; e (iii) não agiram com a finalidade de auferir vantagem.

${ }^{225}$ Diversos são os argumentos normalmente utilizados pela defesa para provar que não houve acesso à informação privilegiada. Um dos mais comuns é o que busca desconstruir a caracterização de determinada informação como privilegiada que, como visto, pode ser definida como uma informação sigilosa que tem o potencial de influir de modo ponderável na cotação dos valores mobiliários de emissão de determinada companhia e/ou na decisão dos investidores de comprar ou vender tais valores mobiliários. Assim, por diversas vezes, a CVM já enfrentou os argumentos de defesa que buscavam demonstrar (i) que a informação já havia sido divulgada ou vazado no mercado, estando refletida na cotação dos valores mobiliários e não podendo, portanto, ser considerada como uma informação sigilosa; e/ou (ii) que a informação não era relevante, ou por não ter o potencial de impactar a cotação dos valores mobiliários de emissão da companhia, ou pelo fato de ainda não ter sido completamente confirmada, o que a tornaria incerta e, portanto, sem utilidade para fins de negociação antecipada. Para alguns casos em que se discutiu a configuração de determinada informação como relevante, confira-se (i) Inquérito Administrativo CVM n 1/78, j. 02.02.1979; (ii) Inquérito Administrativo CVM n 2/79, j. 06.08.1979; (iii) Inquérito Administrativo CVM ${ }^{\circ} 3 / 83$, j. 10.06.1985; (iv) Inquérito Administrativo $\mathrm{CVM} \mathrm{n}^{\circ}$ 5/83, j. 08.03.1985; (v) PAS CVM nº 06/2003, j. 14.09.2005; (vi) PAS CVM n 04/04, j. 28.06.2006; (vii) PAS CVM n ${ }^{\circ} 22 / 04$, j. 20.06.2007; e (viii) PAS CVM n ${ }^{\circ} 24 / 05$, j. 07.10.2008. Outro argumento comumente utilizado pela defesa para demonstrar que não houve acesso à informação privilegiada, notadamente em casos envolvendo instituições financeiras e intermediárias, é aquele relacionado à existência de procedimentos de segregação das atividades da instituição, conhecido pela expressão em inglês "chinese wall". Normalmente, informações sigilosas sobre determinada companhia tem sua circulação restrita a determinado setor. Assim, em alguns casos, a CVM já discutiu se procedimentos adequados de chinese wall seriam suficientes para provar que não obstante a existência de uma informação relevante, o suposto insider não teria negociado com base nela, uma vez que a segregação das diversas áreas teria impedido que a informação chegasse até ele. Para casos que envolveram a discussão sobre a adoção de procedimentos de chinese wall como prova de que não houve acesso a informações relevantes, confira-se (i) PAS CVM n ${ }^{\circ} 18 / 01$, j. 04.11.2004; (ii) PAS $\mathrm{CVM} \mathrm{n}^{\circ}$ 06/2003, j. 14.09.2005; e (iii) PAS CVM n RJ2009/13459, j. 30.11.2010.

${ }^{226}$ Obviamente que tanto este argumento quanto o argumento relacionado ao acesso à informação não se aplicam nos casos em que a proibição de negociar ações é objetiva, como no período anterior à divulgação do ITR, já referido acima. Nos casos envolvendo negociação de ações durante o black-out period, os argumentos apresentados pela defesa para justificar as operações costumam ser rejeitados pela CVM. Não obstante, os principais argumentos para sustentar esta segunda linha de defesa buscam demonstrar que determinada negociação, apesar de parecer atípica e ter sido influenciada por informações privilegiadas, foi, na verdade, apenas parte da estratégia de investimento normalmente adotada pelo acusado. Assim, a defesa, traçando o perfil operacional do potencial insider, busca demonstrar que aquela transação supostamente irregular é na verdade um negócio comumente feito pelo acusado, que teria sido realizado independentemente de qualquer informação privilegiada. A manutenção e a mudança do perfil operacional costumam ser um dos principais indícios considerados pela CVM para acusar e condenar/absolver alguém pelo uso de informações privilegiadas. Para casos envolvendo a discussão sobre a manutenção/mudança do perfil operacional como um indício de insider trading, confira-se os seguintes precedentes: (i) PAS CVM n ${ }^{\circ}$ 13/00, j. 17.04.2002; (ii) PAS CVM n ${ }^{\circ}$ 18/01, j. 04.11.2004; (iii) PAS CVM n 06/2003, j. 14.09.2005; (iv) PAS CVM n ${ }^{\circ} 17 / 02$, j. 25.10.2005; (v) PAS CVM n ${ }^{\circ} 22 / 04$, j. 20.06.2007; (vi) PAS CVM n ${ }^{\circ}$ 24/05, j. 07.10.2008; (vii) PAS $\mathrm{CVM} \mathrm{n}^{\circ}$ 19/09, j. 07.06.2011; (viii) PAS CVM n 13/09, j. 13.12.2011; e (ix) PAS CVM n 11/09, j. 
Por fim, deve-se atentar para o fato de que o requisito "finalidade de auferir vantagem" não se confunde com a efetiva obtenção de vantagem por parte do insider, isto é, o tipo administrativo do insider trading é formal, não dependendo da produção de resultado ${ }^{227}$. Não há, tampouco, a necessidade de que o insider reverta a sua posição, ou seja, que revenda após a compra, ou que recompre após a venda, bastando que, quando da compra ou venda de determinado valor mobiliário (normalmente ações) de emissão da companhia ou não ${ }^{228}$, se enquadre nos requisitos da vedação prevista na norma. Tal entendimento encontra-se consolidado pela CVM, conforme se depreende dos trechos abaixo transcritos:

[...] entendo que a Lei das S.A., em seu art. $155, \S 1^{\circ}$, não sanciona apenas a compra feita pelo "insider", na qual fique configurada sua intenção de lograr lucro na revenda das ações. Tendo utilizado informações confidenciais em proveito próprio, o insider está descumprindo o seu dever de lealdade. Ao comprar ações da companhia com base em informações desconhecidas pelo mercado, infringe o padrão de lealdade que deve seguir, enquanto administrador da companhia aberta. Para caracterização do insider trading a Lei não exige, portanto, que o insider realize lucro na operação. Basta que obtenha vantagem, ou seja, um ganho patrimonial, ou que evite determinado prejuízo. (Inquérito Administrativo CVM n ${ }^{\circ}$ 4/85, j. 04.11.1986. Voto do Diretor Nelson Eizirik)

$* * * * *$

Por fim, um último aspecto sobre o qual muito já se disse em doutrina, mas que ainda sim merece ser comentado, é que a configuração do insider trading independe da existência de lucro na negociação. Este, no entanto, é um fator que pode vir a ser levado em consideração como indício do uso indevido da informação, uma vez que, supõe-se, o comitente com uma vantagem excepcional sobre os demais tende a

03.04.2012. Outro argumento utilizado por esta linha de defesa é aquele que busca demonstrar que as negociações se deram de acordo com a política de negociação da companhia. Em verdade, antes de abrir um processo de insider trading, a CVM busca, em regra, obter esclarecimentos junto aos investigados sobre as razões que o levaram a negociar determinada ação em determinado período. Caso, durante esta fase inicial, o investigado demonstre que a negociação se deu de acordo com a política de negociação estabelecida pela companhia, o processo possivelmente não será instaurado. Estes argumentos de defesa também são utilizados para demonstrar que o insider não agiu com a finalidade de auferir vantagem.

${ }^{227}$ Não obstante, a CVM já considerou o lucro relativamente baixo como atenuante no momento de fixação da pena. Neste sentido, confira-se o PAS CVM n 2003/5627, j. 28.01.2005.

228 A propósito, confira-se o caso em que os administradores de uma companhia aberta foram condenados administrativamente pelo uso de informações privilegiadas em operações com ações de emissão da Perdigão S.A., dado que obtiveram, em razão de cargo que ocupavam na Sadia S.A., informação privilegiada sobre oferta hostil de aquisição do controle da Perdigão S.A. (PAS CVM n ${ }^{\circ}$ 2007/117 e 2007/118, j. 26.02.2008). 
auferir um lucro não menos excepcional. (PAS CVM n ${ }^{\circ}$ 06/2003, j. 14.09.2005. Voto da Diretora Norma Parente)

$* * * * *$

O fato de o prejuízo, evitado pelo acusado na alienação de suas ações da Sadia, ter sido pequeno (no valor de $\mathrm{R} \$ 2.141,00$ ) não me comove, pois entendo, com base no $\S 4^{\circ}$ do art.155 da Lei $n^{\circ}$ 6.404/76, que dispõe sobre a proibição de utilização de informação relevante com a finalidade de auferir vantagem para si e para outrem no mercado de valores mobiliários, que se deve levar em conta a finalidade da operação e não o lucro eventualmente obtido com a negociação. Ademais, o prejuízo evitado com a alienação foi baixo porque eram poucas as ações da Sadia detidas pelo acusado, o que, de qualquer forma, não evitou que ele se desfizesse da totalidade da posição que possuía. (PAS CVM n ${ }^{\circ}$ 13/09, j. 13.12.2011. Voto do Diretor Otávio Yazbek)

$* * * * *$

Em segundo lugar, mesmo que os acusados não tivessem apurado lucro nas respectivas operações, como efetivamente ocorreu, já é consolidado o entendimento do Colegiado da CVM de que o lucro não é requisito necessário para a caracterização do ilícito de uso indevido de informações privilegiadas. A efetiva consecução da vantagem não integra a caracterização do insider, basta, simplesmente, a negociação

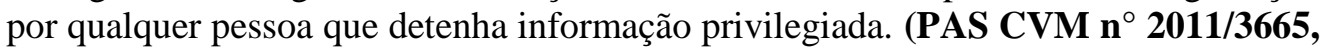
j. 03.04.2012. Voto da Diretora Luciana Pires Dias)

\subsection{A utilização de indícios e presunções}

Como visto, tanto o Colegiado da CVM como a própria regulamentação administrativa da autarquia passaram a estabelecer algumas presunções, visando facilitar o julgamento de casos de insider trading que, por sua natureza, costumam ser de grande complexidade, requerendo um volume de informações, documentos e cruzamento de dados bastante significativo.

Além de tais presunções, o corpo investigativo da CVM também passou a lançar mão, ao longo dos anos, e na medida em que novos casos envolvendo negociação com base em informações privilegiadas surgiam e eram julgados, de uma série de indícios capazes de fundamentar uma acusação de insider trading.

Tais indícios são inúmeros e variam de caso a caso, podendo ser desde uma operação atípica feita por um determinado investidor, uma oscilação 
repentina e significativa de um determinado papel em um curto período de tempo, até o relacionamento pessoal mantido com determinados participantes do mercado. De posse de uma série de indícios que entenda serem múltiplos, convergentes, e graves, a acusação instaura o processo visando apurar a responsabilidade pelo uso de informações privilegiadas.

Neste contexto, na grande maioria dos casos de insider trading, os acusados costumam utilizar um argumento de defesa no sentido de que nem a acusação, muito menos uma eventual condenação pelo uso de informações privilegiadas poderia se basear em indícios, por mais sérios e graves que eles sejam.

Assim, por diversas vezes, o Colegiado da CVM viu-se obrigado a se manifestar sobre esta questão, tendo consolidado o entendimento de que a utilização de indícios e presunções pode, sim, basear uma acusação e até mesmo uma eventual condenação pela negociação com base em informações privilegiadas, conforme se depreende dos precedentes abaixo transcritos:

A esse respeito, lembro, desde logo, que a lei não exige que o convencimento do julgador esteja amparado por uma demonstração absoluta e inquestionável dos fatos, com provas apontando univocamente na mesma direção. Ao contrário, vigora no Brasil o principio do livre convencimento motivado, segundo o qual o juiz pode apreciar livremente os elementos probatórios do processo, devendo, no entanto, fundamentar a formação de seu convencimento.

É possível, portanto, que haja provas contraditórias entre si, sem que isto impeça o julgador de formar sua convicção em um ou outro sentido, a depender do valor que atribua a cada uma destas provas. $\mathrm{E}$ ao falar em provas também me refiro às provas indiretas, isto é aos elementos que por si só sejam conhecidos e irrelevantes, mas que em conjunto autorizem a presunção quanto a fatos desconhecidos e relevantes.

Isso é importante porque em se tratando de "insider trading", em que via de regra é necessário demonstrar que o agente detinha conhecimento da informação relevante, a prova definitiva e irrefutável do ilícito será praticamente impossível, exceto na hipótese de confissão por parte do acusado.

Evidentemente, não se quer com isso negar a importância de um suporte probatório adequado das imputações, nem deixar de reconhecer que, diante de uma dúvida razoável sobre os fatos, impõe-se a absolvição dos defendentes. Aqui se está apenas a lembrar que a fronteira entre os fatos comprovados e as meras especulações não é 
demarcada de forma objetiva, mas sim pela análise, subjetiva porém fundamentada, do julgador. (PAS CVM ${ }^{\circ}$ 24/05, j. 07.10.2008. Voto do Diretor Sérgio Weguelin)

$* * * * *$

Trata-se de mais um caso tipificado como de insider trading em que é natural que a acusação seja constituída por indícios. Dado o princípio do livre convencimento do julgador, os indícios equivalem a qualquer meio de prova, estando inclusive previstos no art. 239 do Código de Processo Penal, dentro do Título VVI, correspondente às provas, sendo a decisão obrigatoriamente motivada.

Como já tive oportunidade de me manifestar em diversas ocasiões, o sistema jurídico brasileiro não estabelece uma hierarquia de provas, todas tendo o mesmo valor. Determinante é que os indícios sejam vários, fortes e convergentes, suficientes a sustentar uma condenação.

Para a resolução de casos em que a prova direta torna-se impossível, a prova indiciária é fundamental, porquanto a solução somente seria viável na hipótese em que a intenção dos acusados pudesse ser pesquisada e afirmada, independentemente, é óbvio, de confissão.

Entretanto, como qualquer meio de prova, um indício, ou mesmo um conjunto de indícios sem consistência, não é suficiente para a condenação. A robustez deste conjunto de indícios é salutar para que se tenha o fato por provado. (PAS CVM n ${ }^{\circ}$ 13/09, j. 13.12.2011. Voto do Diretor Eli Loria)

$* * * * *$

Preliminarmente, contudo, gostaria de ressaltar que, como exposto pelo Diretorrelator, nos casos envolvendo insiders secundários, a utilização de indícios na construção da peça acusatória e na eventual condenação dos acusados mostra-se não só como um caminho natural, mas, muitas vezes, como o único caminho a ser seguido; isso porque penso que a prova definitiva e irrefutável da prática de insider de mercado é bastante complexa, exceto se, de alguma forma, o vínculo ficar claramente evidente, como ocorreria na hipótese de haver uma confissão, por exemplo. Entendo, assim, possível que uma condenação seja baseada em prova indiciária, formada por um conjunto de indícios sérios, consistentes e convergentes, e respeitado o princípio do livre convencimento motivado do julgador e essas provas indiciárias são, inclusive, reconhecidas expressamente pelo art. 239 do Código de Processo Penal.

Com efeito, considero que os principais indícios que devem ser considerados para a análise de um caso como o presente são: a oportunidade de negociação, apesar de, como já referido, se reconhecer que o lucro não é elemento intrínseco da negociação com informação privilegiada, a tipicidade do histórico de operações com aquelas ações pelo investidor e a apresentação de tese convincente para justificar as operações realizadas, sem prejuízo, por óbvio, de outros indícios que, eventualmente, surgiram durante a investigação; o que, no presente caso, ocorreu com a demonstração, pela acusação, das relações existentes entre os acusados e, 
eventualmente, entre estes e a companhia. (PAS CVM n ${ }^{\circ}$ 13/09, j. 13.12.2011. Voto do Diretor Otávio Yazbek)

De tudo o que foi até aqui exposto, observa-se que os casos envolvendo a utilização de informações privilegiadas mostram-se, em sua grande maioria, cercados de grande complexidade, exigindo da máquina estatal capital humano e financeiro em um volume significativo. Diante disso, julga-se pertinente fazer a seguinte indagação: desde que a CVM foi criada, em 1976, quantos dos casos de insider trading julgados pela autarquia efetivamente terminaram em condenação dos acusados, revertendo, portanto, em benefícios para a CVM e para o mercado em geral?

Em outras palavras: de todas as vezes que a CVM dispendeu seus recursos humanos, técnicos e financeiros para investigar e processar um indivíduo por se utilizar de informações privilegiadas, em quantas houve, de fato, um desfecho que sinalizasse ao mercado que a prática do insider trading poderia não ser um bom negócio?

\subsection{Insider trading em números: um primeiro argumento a favor da legalização}

Conforme observado por FRIJNS et. Al., "deterrence of prohibited activities is a function of both the severity of the punishment (sanctions) and probability of detection and prosecution (enforcement)". Logo, concluem os autores, "it is important for law makers to develop laws with an eye on both severity and enforceability of the laws",229.

Com efeito, SHEN afirma que a mera existência de regras de combate ao insider trading não é suficiente para se garantir um desenvolvimento eficiente do mercado de capitais. De acordo com referido autor, "enforcement

\footnotetext{
${ }^{229}$ FRIJNS, Bart; GILBERT, Aaron B.; e TOURANI-RAD, Alireza. Do Criminal Sanctions Deter Insider Trading? (March 14, 2011). p. 1. Disponível em SSRN: http://ssrn.com/abstract=1785873.
} 
is the key. Recent scholarship concludes that the enforcement of insider trading laws has a strong impact on the cost of capital, whereas passing insider trading laws without enforcing them does not have this effect" (grifado) ${ }^{230}$.

Na definição oferecida pelo já consagrado Black's Law Dictionary, a palavra "enforcement" significa, em tradução livre, "o ato ou processo de fazer cumprir uma lei, ordem, comando, decisão judicial ou contrato". O mesmo dicionário define a expressão "law enforcement" como a "detecção e punição das violações à lei” (grifado) ${ }^{231}$.

Assim, para que as normas de combate ao insider trading possam efetivamente contribuir para um mercado de capitais mais eficiente, o que, como visto, é um dos objetivos da regulação deste mercado no Brasil, expressamente elencado no Art. $4^{\circ}$ da Lei $n^{\circ}$ 6.385/76, não basta que esta prática seja proibida. É preciso que a negociação com base em informações privilegiadas seja detectada e os responsáveis - ou ao menos a maioria deles sejam punidos. No entanto, esta não parece ser a realidade brasileira.

Com base em dados disponíveis no site da CVM, foram levantados todos os casos de insider trading já julgados pela CVM desde a sua criação, em 1976, até a presente data. ${ }^{232}$

Conforme exposto na tabela ${ }^{233}$ abaixo, os números apontam que mesmo desconsiderando as milhares de transações possivelmente feitas por insiders

\footnotetext{
${ }^{230}$ SHEN, Han. A comparative study of insider trading regulation enforcement in the U.S. and China. Journal of Business \& Securities Law, Vol. 9, No. 1, Fall 2008. p. 42. Disponível em SSRN: http://ssrn.com/abstract $=964548$

${ }^{231}$ GARNER, Bryan A. (editor chefe). Black's Law Dictionary. $9^{a}$ edição. Estados Unidos: West Publishing Co., 2009. p. 608 e 963.

${ }^{232}$ A última verificação foi feita em 31.05.2013.

${ }^{233}$ TIMBÓ, Ivo Cordeiro Pinho. Regime Jurídico da Informação no Mercado de Capitais. Dissertação de Mestrado (Pós Graduação Stricto Sensu em Direito Político e Econômico) - Universidade Presbiteriana Mackenzie, São Paulo, 2006. A esquematização desta tabela foi originalmente desenvolvida na dissertação de mestrado de Ivo Cordeiro Pinho Timbó, que somente trazia os casos julgados pela CVM até 2006. O presente trabalho revisitou todos os casos julgados desde 1976, efetuou alguns ajustes e completou a tabela com os casos julgados entre 2006 e 2013.
} 
que sequer vem à tona, seja por não serem detectadas pelos mecanismos de monitoramento da CVM e da BM\&FBOVESPA, seja por não apresentarem os requisitos suficientes para embasar a instauração de um processo, quando se trata de insider trading, a existência de normas e sua aplicação pela CVM parecer não ter se revelado a solução mais eficiente para o mercado.

\begin{tabular}{|c|c|c|c|c|c|c|c|}
\hline Ano & $\begin{array}{c}\text { Proc. } \\
\text { Instaurados }\end{array}$ & $\begin{array}{c}\mathbf{N}^{\circ} \text { de } \\
\text { indic. }\end{array}$ & $\begin{array}{c}\text { Excl. de } \\
\text { Indiciados** }\end{array}$ & Absolv. & Advert. & Multa & $\begin{array}{c}\text { Inabilit. } \\
\text { Ou } \\
\text { Susp. }\end{array}$ \\
\hline $\mathbf{1 9 7 6}$ & - & - & - & - & - & - & - \\
\hline $\mathbf{1 9 7 7}$ & - & - & - & - & - & - & - \\
\hline $\mathbf{1 9 7 8}$ & - & - & - & - & - & - & - \\
\hline $\mathbf{1 9 7 9}$ & 3 & 23 & 2 & 16 & 5 & 1 & - \\
\hline $\mathbf{1 9 8 0}$ & - & - & - & - & - & - & - \\
\hline $\mathbf{1 9 8 1}$ & 1 & 1 & - & - & - & 1 & - \\
\hline $\mathbf{1 9 8 2}$ & 1 & 11 & - & - & 2 & 9 & - \\
\hline $\mathbf{1 9 8 3}$ & - & - & - & - & - & - & - \\
\hline $\mathbf{1 9 8 4}$ & 1 & 1 & - & 1 & - & - & - \\
\hline $\mathbf{1 9 8 5}$ & 4 & 12 & 4 & 7 & 1 & - & - \\
\hline $\mathbf{1 9 8 6}$ & 1 & 1 & - & 1 & - & - & - \\
\hline $\mathbf{1 9 8 7}$ & 1 & 1 & - & - & 1 & - & - \\
\hline $\mathbf{1 9 8 8}$ & - & - & - & - & - & - & - \\
\hline $\mathbf{1 9 8 9}$ & 1 & 1 & - & - & - & 1 & - \\
\hline $\mathbf{1 9 9 0}$ & - & - & - & - & - & - & - \\
\hline $\mathbf{1 9 9 1}$ & 2 & 14 & - & 4 & 4 & 6 & - \\
\hline $\mathbf{1 9 9 2}$ & - & - & - & - & - & - & - \\
\hline $\mathbf{1 9 9 3}$ & 1 & 6 & - & - & 1 & 3 & 2 \\
\hline $\mathbf{1 9 9 4}$ & - & - & - & - & - & - & - \\
\hline $\mathbf{1 9 9 5}$ & 2 & 7 & - & 7 & - & - & - \\
\hline $\mathbf{1 9 9 6}$ & 1 & 6 & - & - & 6 & - & - \\
\hline $\mathbf{1 9 9 7}$ & - & - & - & - & - & - & - \\
\hline $\mathbf{1 9 9 8}$ & 2 & 10 & - & 2 & - & 4 & 4 \\
\hline $\mathbf{1 9 9 9}$ & - & - & - & - & - & - & - \\
\hline $\mathbf{2 0 0 0}$ & 1 & 2 & - & 2 & - & - & - \\
\hline $\mathbf{2 0 0 1}$ & - & - & - & - & - & - & - \\
\hline $\mathbf{2 0 0 2}$ & 2 & 14 & 8 & 4 & - & 2 & - \\
\hline $\mathbf{2 0 0 3}$ & 1 & 1 & - & 1 & - & - & - \\
\hline $\mathbf{2 0 0 4}$ & 1 & 51 & - & 49 & - & 2 & - \\
\hline $\mathbf{2 0 0 5}$ & 4 & 10 & - & 8 & 1 & 1 & - \\
\hline $\mathbf{2 0 0 6}$ & 5 & 21 & 15 & 4 & - & 2 & - \\
\hline & & & & & & & \\
\hline
\end{tabular}




\begin{tabular}{|c|c|c|c|c|c|c|c|}
\hline $\mathbf{2 0 0 7}$ & 4 & 32 & 1 & 9 & 3 & 19 & - \\
\hline $\mathbf{2 0 0 8}$ & 6 & 29 & 2 & 18 & 1 & 6 & 2 \\
\hline $\mathbf{2 0 0 9}$ & 5 & 11 & 3 & 1 & - & 7 & - \\
\hline $\mathbf{2 0 1 0}$ & 16 & 49 & 35 & 8 & - & 6 & - \\
\hline $\mathbf{2 0 1 1}$ & 4 & 14 & 1 & 2 & - & 11 & - \\
\hline $\mathbf{2 0 1 2}$ & 11 & 33 & 8 & 23 & - & 2 & - \\
\hline $\mathbf{2 0 1 3}$ & - & - & - & - & - & - & - \\
\hline Total: & $\mathbf{8 1}$ & $\mathbf{3 6 2}$ & $\mathbf{7 9}$ & $\mathbf{1 6 7}$ & $\mathbf{2 5}$ & $\mathbf{8 3}$ & $\mathbf{8}$ \\
\hline
\end{tabular}

* Na contabilização dos processos instaurados, foram considerados tantos os processos efetivamente julgados quanto aqueles encerrados pela celebração de termo de compromisso.

** Nos anos de 1979 e 1985, a exclusão de indiciados se deu por vícios da acusação. Nos demais anos, a exclusão de indiciados se deu mediante a celebração de termo de compromisso.

Como visto acima, a regulação do insider trading, por estar intimamente ligada à busca por um mercado de capitais cada vez mais eficiente, deve se preocupar não só com a existência de regras que proíbem o uso de informações privilegiadas, mas também, e principalmente, com a real possibilidade de aplicar estas regras e punir aqueles que as infringem.

O que a tabela demonstra, no entanto, é que aproximadamente $67 \%$ das pessoas que são processadas por terem supostamente negociado com base em informações privilegiadas ou são absolvidas (46\%) ou celebram termo de compromisso (21\%). Apenas $22 \%$ dos indiciados são multados, $2 \%$ são condenados a inabilitação ou suspensão e 7\% são advertidos.

Os anos de 2004 e 2012 chamam ainda mais a atenção. Em 2004, das 51 pessoas processadas por insider trading, 49 foram absolvidas. No ano de 2012, dos 33 processados, 23 foram considerados inocentes pela CVM e 8 celebraram termo de compromisso. Diante destes números, cabe indagar: a atuação sancionatória da CVM no que diz respeito ao insider trading está cumprindo seu objetivo de tornar o mercado de capitais mais eficiente? Ao que tudo indica, não. Os atuais números de acusados, condenações e absolvições tem um grande potencial de passar ao mercado a mensagem de que a negociação com base em informações privilegiadas, se e quando detectada pela CVM, provavelmente terminará em absolvição. 
Neste ponto, vale conferir trecho do voto do Diretor Pedro Oliva Marcílio de Sousa no âmbito do PAS CVM nº 16/03, julgado em 08.11.2006:

02. [...] Há um grande esforço na CVM para uma maior efetividade da sua atuação punitiva, pois se tem a consciência que o funcionamento equânime e eficiente do mercado de valores mobiliários depende da observância das regras existentes e a atuação punitiva é parte complementar necessária para que as regras sejam conhecidas e respeitadas.

03. Maior efetividade na atividade sancionatória não significa maior número de condenações. Significa certeza de punição se, e somente se, uma regra for violada. Em realidade, como é impossível alcançar essa certeza, pois o regulador e as demais forças do mercado não são oniscientes e não tem condições de detectar, comprovar e processar todas as infrações, deve-se entender "certeza" como grande probabilidade de detecção, comprovação e processamento das infrações.

04. Maior efetividade sancionatória, no entanto, significa menor número de absolvições. Da mesma forma que uma violação à regra existente, que não seja seguida da punição apropriada, retira a segurança sobre as regras existentes, uma condenação inadequada traz a mesma insegurança e os mesmos efeitos nefastos para o desenvolvimento do mercado de valores mobiliários. Ambas negam a certeza do direito, ambas põem em dúvida quais são as regras que se aplicam.

\section{$[\ldots]$}

10. [...] As absolvições são ruins por vários motivos. Internamente, duas consequências óbvias: (i) recursos humanos e materiais da CVM estão sendo utilizados sem que se obtenha um resultado útil; e (ii) as pessoas envolvidas com a atividade acusatória ficam com a sensação de impunidade. Ou seja, passamos, internamente, a impressão de baixa efetividade. Externamente, também, duas consequências óbvias: (i) impomos custos excessivos aos particulares absolvidos, já que precisam apresentar defesa e justificar-se junto à comunidade em razão dessas acusações; e (ii) a atividade sancionatória perde credibilidade, pois se vê que o resultado mais provável, estatisticamente, é a absolvição. Ou seja, passamos a impressão de baixa efetividade.

11. Para o Colegiado, isso também é desgastante. Absolver ou condenar implica o mesmo gasto de tempo e esforço. É preciso analisar os autos, analisar as provas apresentadas pela acusação e sua argumentação e, também, analisar as provas apresentadas na defesa e sua argumentação. É preciso, também, reunir-se em sessão, ouvir defesa oral e, finalmente, julgar.

12. O número excessivo de absolvições, muitas das quais derivam das mesmas falhas acusatórias (inexistência de prova, utilização excessiva de pressuposições, interpretação das regras de direito material em sentido diverso da comumente aceita pelo Colegiado), levam não só à impossibilidade de maior dedicação do Colegiado aos casos mais importantes para o mercado e para o aumento da respeitabilidade da CVM e, também, para as demais atividades por nós exercidas. Ficamos, também, com a sensação de que nossas decisões e orientações são, simplesmente, ignoradas. (grifado) 
Corroborando as preocupações acima expressadas e às aproximando dos casos de insider trading, veja-se a posição de MCGEE, analisando a questão no âmbito do mercado de capitais norte-americano:

Taxpayers are adversely affected by insider trading laws, since enormous resources must be placed at the disposal of the police power to do any kind of policing. The resources used to police the insider trading laws might be better used to prevent some real criminal activity from being committed. For any use of government resources, there is a cost and a benefit. Since insider trading is regarded as a victimless crime, if, indeed, it is a crime at all, an argument can be made that the resources government uses to enforce the insider trading laws can be better employed elsewhere. Furthermore, the risk of being caught is small, and the potential gain from using insider information can be enormous, so having an insider trading law on the books will not stop the practice or even reduce it significantly. ${ }^{234}$

Ainda neste contexto, MANNE observa que, à semelhança do que ocorre no Brasil, "the enforcement problems [with the insider trading prohibition] I have just been referring to are inherent in the SEC's insidertrading rule". E prossegue:

The ability to detect the practice will always be difficult, and when the gains that can be realized from the practice, discounted by the risk of being apprehended, are compared to the costs, many people will have the incentive to trade on inside information. $^{235}$

No que se refere aos termos de compromisso, por mais que eles não importem a confissão de culpa dos acusados nem tampouco os inocentem tecnicamente, nos casos de insider trading, a celebração de termos de compromisso pode ser uma boa forma de os insiders equalizarem os riscos versus o retorno que a utilização de informações privilegiadas pode gerar. Em matéria publicada no jornal The New York Times, STEWART dá a exata medida de como esta equação "risco vs. recompensa" nos casos envolvendo insider trading vem sendo sentida nos Estados Unidos:

\footnotetext{
${ }^{234}$ MCGEE, Robert W. Ethical Issues in Insider Trading: Case Studies. pp. 10-11. Disponível em SSRN: http://ssrn.com/abstract=538682.

${ }^{235}$ MANNE, Henry G. Insider trading and property rights in new information. Cato Journal, Vol. 4, No. 3, 1985. p. 937.
} 
Why has insider trading proved so persistent, even in the face of prosecutions and popular Hollywood films like "Wall Street"?

The risk-versus-reward equation that has always been a factor in financial markets has changed drastically in the last 20 years. Ivan F. Boesky, the once-celebrated arbitrageur who admitted to insider trading after preaching to graduates of the University of California, Berkeley in 1986 that "Greed is all right, by the way," had to pay fines and restitution then considered a milestone: $\$ 100$ million.

When the government revealed that Mr. [Michael R.] Milken earned $\$ 550$ million in a single year in the 1980s, the sum astonished Wall Street and even his fellow traders at his now-defunct firm, Drexel Burnham Lambert.

$[\ldots]$

By contrast, the average hedge fund manager in the top 25 performers today makes that in a good year, and a few have earned more than $\$ 4$ billion in a single year. Mr. [Steven A.] Cohen reportedly earned $\$ 1.4$ billion in 2009, and Forbes estimated his net worth in 2012 at $\$ 8.8$ billion. (Mr. Milken's fortune, by comparison, is estimated by Forbes at $\$ 2$ billion, which puts him in the middle of the magazine's list of the richest 400 Americans.)

At the same time, the tactics and technologies available to inside traders today are more sophisticated and more difficult both to detect and to prove.

$[\ldots]$

There's no doubt that the potential for gain "has soared," Robert S. Khuzami, head of enforcement at the S.E.C., told me, and not because there are more takeovers and other market-moving events to trade on. "That's a big change from the 1980s and '90s. Hedge funds can take massive positions, use short-selling and derivatives, and employ trading techniques that aren't transparent, and make huge amounts of money on small fluctuations on price. They don't need to hit a home run on a $\$ 20$ pop on a takeover announcement. These bets may be bunts and singles, but they get to the same place.”

Even at lower rungs of the hedge fund world, the potential gains have shot up. Mathew Martoma, a former SAC trader who was accused last month of using secret information to help SAC gain profits, was paid a $\$ 9.4$ million bonus in 2008 , when he was just 34 .

\section{$[\ldots]$}

Even as the potential rewards have soared, the nature of today's trading - the bunts and singles, as Mr. Khuzami put it - has made enforcement more difficult, leading to what seems to have been a perception of less risk of getting caught. In the wake of the Milken-Boesky era, the government has become sophisticated at monitoring major market-moving events like takeover announcements, to the point that insider trading on major corporate news has become relatively rare (though just this week the S.E.C. charged an old-fashioned insider trading ring based on leaks about proposed mergers and acquisitions). 


\section{$[\ldots]$}

"In the 1980s, you had to meet someone, or have lunch or exchange information in ways that were slower and more visible," Mr. Zabel said. "Now, you can have only the glow of your computer screen on your face and you can scoop up all sorts of valuable information from all over the country or even the world. If you get even little bits, you can trade on a daily or hourly basis on micromovements." ${ }^{236}$ (grifado)

Verifica-se, desta forma, que, o baixo risco de ser condenado pela prática do insider trading, somado aos problemas trazidos pela dificuldade em se identificar, processar e condenar as pessoas que se utilizam de informações privilegiadas para negociar no mercado de valores mobiliários, podem causar o efeito inverso daquele pretendido pelas leis de combate ao insider trading, tornando o mercado de capitais menos eficiente.

A legalização do insider trading, por outro lado, permitiria que a CVM concentrasse seus esforços e recursos limitados na fiscalização e regulamentação de outras questões igualmente relevantes para o mercado de capitais, desonerando a autarquia da responsabilidade de combater uma prática que, por sua natureza, é extremamente difícil de ser eficazmente detida.

Neste sentido, concluem BHATTACHARYA e DAOUK, referindo-se às nornas de combate ao insider trading, "it is sometimes better not to have a security law at all than to enact a security law that will not or cannot be enforced". 237

\footnotetext{
${ }^{236}$ STEWART, James B. In a New Era of Insider Trading, It's Risk vs. Reward Squared. The New York Times. 7 dez. 2012. Disponível em http://www.nytimes.com/2012/12/08/business/insider-tradingpersists-and-gets-stealthier.html?pagewanted=all\&_r $=0$.

${ }^{237}$ BHATTACHARYA, Uptal e DAOUK, Hazem. When no law is better than a good law. (April 27, 2009). AFA 2008 New Orleans Meetings Paper. p. 2. Disponível em http://ssrn.com/abstract=558021
} 


\section{CAPÍTULO 6 - A INEFICIÊNCIA ECONÔMICA DO COMBATE AO INSIDER TRADING: A PROIBIÇÃO É A MELHOR ALTERNATIVA?}

Independentemente da intensa discussão em torno da proibição do insider trading, deve-se reconhecer que a maioria dos países com mercados de capitais desenvolvidos ${ }^{238}$ e suas respectivas autoridades governamentais passaram a enxergar a negociação com base em informações privilegiadas como algo maligno para o mercado, tornando tal percepção uma espécie de verdade absoluta.

Por estas e outras razões, ou, o que é mais provável, não obstante a falta de razões suficientes, o legislador brasileiro, inspirado no direito norteamericano e seguindo a tendência de outros países, entendeu por bem proibir a prática do insider trading, sujeitando seus infratores a sanções civis, administrativas e penais.

Por outro lado, diferentemente dos Estados Unidos, onde o tema é amplamente debatido, a doutrina jurídica e econômica brasileira parece nunca ter dado a atenção merecida à discussão sobre a real necessidade de se combater o insider trading, tendo em conta não somente as consequências que tais normas podem trazer para seus infratores e a relativamente baixa probabilidade de punição, mas também a real eficiência que o combate ao uso de informações privilegiadas confere ao mercado de capitais.

Assim, visando contribuir para a discussão e reflexão sobre o tema no Brasil, o capítulo final deste trabalho analisará os principais argumentos apresentados pelas correntes pró e contra a proibição do insider trading,

\footnotetext{
${ }^{238}$ Em estudo publicado em 2002, BHATTACHARYA e DAOUK constataram que dos 103 países analisados em sua pesquisa, 87 deles possuíam normas que proibiam o insider trading. BHATTACHARYA, U., e DAOUK, H. The World Price of Insider Trading. Journal of Finance, February 2002. p. 2. Disponível em SSRN: http://ssrn.com/abstract=249708
} 
buscando-se identificar, ao final, qual das duas medidas - a proibição ou legalização do insider trading - mostrar-se-ia a mais eficiente para um melhor funcionamento do mercado de capitais brasileiro.

\subsection{A corrente majoritária: o insider trading deve ser proibido}

No entendimento de $\mathrm{YEO}^{239}$ três teorias principais justificariam a proibição do insider trading, quais sejam: (i) a misappropriation theory, segundo a qual aqueles que negociam com base em informações privilegiadas estariam se apropriando indevidamente de informações pertencentes à companhia para obter ganhos pessoais; (ii) a unfair advantage theory, que entende haver uma vantagem injusta por parte do insider em face de sua contraparte no negócio; e (iii) a market stability theory, sustentando que o insider trading ocasionaria um efeito adverso no mercado em termos de transparência e eficiência.

No mesmo sentido, confira-se trecho do voto do Diretor Wladimir Castelo Branco, no âmbito do PAS CVM n 33/00, julgado em 20.12.2002:

45. Desde logo, não é demais lembrar que a regulação do mercado visa a garantir aos investidores a disponibilidade ampla de informações confiáveis e que a base legal da regulação do insider trading, além do princípio da transparência, está apoiada na teoria da apropriação indevida de informações obtidas em razão do cargo ou função para benefício pessoal, da vantagem indevida que o insider possui frente à sua contraparte e do efeito adverso que o insider trading produz na estabilidade do $\underline{\text { mercado }}$ em termos de sua transparência e eficiência. (grifado)

Ressalte-se, contudo, que as teorias acima mencionadas não são excludentes. Pelo contrário. Como observado por YEO, "regulations of the various countries take into consideration all the theories in an attempt to

\footnotetext{
${ }^{239}$ YEO, Victor CS. A Comparative Analysis of Insider Trading Regulation - Who is liable and what are the sanctions? p. 3. Disponível em http://ssrn.com/abstract=260884.
} 
balance the interests of the corporation, the market, the insider and other traders" 240 .

Outros argumentos comumente trazidos pelos que defendem a proibição da negociação com base em informações privilegiadas são: (i) o insider trading prejudicaria a companhia, seus acionistas e os investidores em geral; e (ii) o insider trading tenderia a criar um risco moral que faria com que os administradores buscassem obter ganhos com notícias negativas sobre a companhia.

A seguir, cada um destes argumentos será analisado em maior profundidade.

\subsubsection{Misappropriation theory}

A misappropriation theory pode ser dividia em duas subteorias. Para a primeira delas, a justificativa para a proibição da utilização de informações privilegiadas residiria no fato de que, sendo tais informações de propriedade da companhia, não poderiam os administradores e demais pessoas que a elas tenham acesso por força de uma relação fiduciária, se aproveitar dessa situação para obter ganhos pessoais. Assim, esta relação fiduciária e este compromisso de confidencialidade dariam origem a uma obrigação legal de não agir de maneira a prejudicar a companhia ${ }^{241}$.

\footnotetext{
${ }^{240}$ Ibid. p. 7.

${ }^{241}$ Os principais argumentos que embasam esta vertente da misappropriation theory podem ser encontrados nos leading cases norte-americanos Chiarella v. United States, 445 US 222 (1980) e Dirks v. Securities and Exchange Commission, 463 US 646 (1983). Em Dirks v. Securities and Exchange Commission, a Suprema Corte esclareceu a vertente da misappropriation theory que leva em conta a relação fiduciária dos envolvidos em um caso de insider trading, delineando os limites da responsabilidade dos insiders secundários (tippees). De acordo com a decisão adotada neste caso, aquele que tiver acesso a uma informação privilegiada deverá se abster de negociar ou divulgar a informação caso o provedor da informação (tipper) tenha quebrado seu dever fiduciário para com os acionistas, se beneficiando com o vazamento da informação.
} 
A segunda vertente da misappropriation theory sustenta que a companhia detém, de forma geral, a propriedade sobre as informações por ela geradas e, mais especificamente, o direito exclusivo de utilizar tais informações. Assim, ninguém poderia se valer das informações "geradas" pela companhia sem o seu consentimento. Para esta vertente, a existência ou não de uma relação fiduciária entre a companhia e aquele que se utiliza da informação privilegiada é irrelevante ${ }^{242}$.

Em termos práticos, proibir o insider trading significaria alocar o direito de propriedade sobre as informações para a companhia, de forma que qualquer utilização destas informações por quem quer que seja seria considerada ilegal. Em sentido contrário, permitir o insider trading significaria alocar o direito de propriedade sobre as informações produzidas no âmbito da companhia para os insiders, de modo que a utilização destas informações para negociar com ações no mercado não configuraria qualquer tipo de "misappropriation"243.

\subsubsection{Unfair advantage theory}

Seguindo a classificação acima proposta, a segunda teoria que justificaria a proibição do insider trading é a chamada unfair advantage theory. Para os seguidores desta teoria, as operações no mercado de capitais só poderiam se dar entre partes que possuem igualdade de acesso à informação. Logo, um insider, operando com o benefício da informação privilegiada, teria uma vantagem informacional (informational advantage) sobre os demais participantes do mercado e, portanto, não poderia negociar enquanto tal informação não fosse tornada pública ${ }^{244}$.

\footnotetext{
${ }^{242} \mathrm{O}$ caso mais citado para embasar os argumentos desta vertente da misappropriation theory é o leading case da Suprema Corte americana Carpenter v. United States, 484 US 19 (1987).

243 BAINBRIDGE, Stephen M. Insider Trading: An Overview. p. 19. Disponível em http://ssrn.com/abstract=132529.

${ }^{244}$ Os argumentos da unfair advantage theory originaram-se do conhecido caso norte-americano Cady, Roberst \& Co, 40 SEC 907 (1961), sendo este caso a primeira enforcement action trazida pela SEC
} 
A unfair advantage theory também costuma trazer argumentos ligados a questões de ordem ética. Neste sentido, confiram-se as lições de EIZIRIK:

As razões de ordem ética [para a proibição do insider trading] derivam do princípio da igualdade de acesso às informações, o denominado market egalitarianism. Com efeito, há um total desequilíbrio entre a posição do insider e a dos demais participantes do mercado, sendo eticamente condenável a obtenção de lucros unicamente em função da utilização de informações confidenciais que o insider sabe que não estão disponíveis para o público. Assim, a legislação, nos diferentes países, busca impedir que os insiders obtenham vantagens decorrentes da inevitável "assimetria" de informações, uma vez que eles sempre terão acesso a elas antes dos investidores do mercado. ${ }^{245}$

\section{Em termos um tanto quanto caricatos, PROENÇA chega a comparar a} vantagem informacional de um insider a de um assassino que arma uma emboscada para sua vítima:

Não se pode fugir à evidência do desvalor da conduta do insider. Cabe compará-la com a do assassino que se vale de uma emboscada: a vítima não sabe que o seu matador tem conhecimento da intenção, ou o costume de passar por aquele lugar, pois, se soubesse, não passaria. Já o matador tem todas as informações necessárias para matar a vítima: sabe por onde e quando ela passará por aquele lugar, e lá estará para eliminar a sua vida. A vítima passa desprevenida e o matador dispara a arma e logra o seu intento. O legislador penal compreendeu o repúdio social à emboscada $\mathrm{e}$ por isso mesmo constituiu como um agravante do homicídio. ${ }^{246}$

contra o insider trading. Em Cady, Roberts \& Co, a SEC entendeu que "a corporate insider must disclose all material nonpublic information known to him before trading, or if disclosure is improper or impracticable, abstain from trading". Foi a partir deste entendimento que surgiu a expressão em inglês conhecida como "disclose or abstain from trading", isto é, divulgue ou abstenha-se de negociar. A aplicabilidade desta regra foi posteriormente ampliada para abranger não só o "corporate insider", mas qualquer pessoa, no famoso caso SEC v. Texas Gulf Sulphur, 394 US 976 (1969), quando o Second Circuit Court of Appeals entendeu que "anyone in possession of material inside information must either disclose it to the investing public, or (...) must abstain from trading in or recommending the securities concerned while such inside information remains undisclosed". Esta interpretação extensiva adotada no caso Texas Gulf Sulphur, no entanto, não foi completamente aceita em decisões judiciais posteriores. Com efeito, em Chiarella v. United States, 445 US 222 (1980), a Suprema Corte estreitou significativamente a abrangência das normas coibidoras do insider trading, ao sustentar que o dever de se abster de negociar quando de posse de informações privilegiadas não adviria da mera posse de tais informações, mas sim de uma relação fiduciária ou outra relação de confiança similar entre o insider e aquele que alega ter sofrido prejuízos com a negociação.

${ }^{245}$ EIZIRIK, Nelson Laks; GAAL, Ariádna B.; PARENTE, Flávia; HENRIQUES, Marcus de Freitas. Mercado de Capitais - regime jurídico. 2. ed. (revisada e atualizada). Rio de Janeiro: Renovar, 2008. p. 524.

${ }_{246}$ PROENÇA, José Marcelo Martins. O que falta à criminalização do insider trader no Brasil. Disponível em http://www.bovespa.com.br/Investidor/Juridico/051206NotA.asp. 
Exageros à parte, BRUDNEY ${ }^{247}$ explica que uma vantagem informacional é considerada injusta quando o investidor não pode adquirir a mesma informação de forma independente e legítima. Assim, ao se aproveitar de seu maior acesso a informações, o insider geraria um "sense of unfairness" no investidor, pois este nunca conseguiria superar a vantagem do insider, não importa o quão diligente seja o investidor. Para o autor, outras vantagens informacionais poderiam ser superadas com esforço e diligência e, portanto, não gerariam esse sentimento de injustiça.

Em termos práticos, a suposta "injustiça" sofrida pelo investidor residiria no fato de que ao negociar com um insider, o primeiro pagaria o preço "errado" pela ação.

Neste ponto, de modo a aproximar a discussão ora em análise do campo prático, consideremos o seguinte caso concreto, ocorrido nos Estados Unidos, e que será utilizado como exemplo base nos diversos argumentos pró e contra a proibição do insider trading: em março de 1959, funcionários da Texas Gulf Sulphur Co. ("TGS") encontraram evidências de grandes quantidades de minério próximo à cidade de Timmins, em Ontário, Canadá, e em outubro de 1963, referida companhia começou a realizar pesquisas no solo desta área. Após algumas extrações de amostras, descobriu-se que havia uma grande quantidade de reservas comerciais de cobre e zinco. O presidente da TGS, então, deu ordens expressas aos funcionários que trabalhavam na exploração a manterem sigilo absoluto, ao ponto de não poderem informar nem mesmo a alguns dos diretores da própria TGS. Em dezembro de 1963, uma nova descoberta na mesma área apontou para a existência de quantidades nunca antes vistas de cobre, zinco e prata. Assim, nos meses que se seguiram, a TGS passou a adquirir os terrenos onde estas quantidades gigantescas de minério

247 BRUDNEY, Victor. Insiders, Outsiders, and Informational Advantages under the Federal Securities Laws. Harvard Law Review, Vol. 93, No. 2, (Dez., 1979). p. 332-334, 346. 
estavam localizadas. Após negar por algumas vezes rumores referentes à descoberta, a TGS finalmente divulgou o feito ao mercado em 16 de abril de 1964.

No entanto, entre novembro de 1963 e março de 1964, diversos insiders da TGS que sabiam da descoberta compraram ações e/ou opções da companhia. Durante este período, os insiders conseguiram comprar ações por preços que estavam subindo lentamente, adquirindo tais ações entre US\$18,00 e US $\$ 25,00$. Quando os rumores começaram a se intensificar no final de março e início de abril de 1964, o preço das ações subiu para US\$30,00. No dia 16 de abril de 1964, a ação abriu o pregão cotada a US\$31,00, mas rapidamente subiu para US\$37,00. Cerca de um mês depois, em maio de 1964, as ações da TGS estavam sendo negociadas a US $\$ 58,00$ por ação - um aumento de $222 \%$ em relação à cotação de novembro ${ }^{248}$.

Tomando-se o exemplo acima, os defensores da unfair advantage theory argumentariam que os investidores que venderam suas ações aos insiders à US\$18,00 negociaram a um preço “errado", já que com a posterior divulgação sobre a descoberta de minério, as ações da companhia chegaram a US $\$ 58,00$. Logo, o acionista que vendeu suas ações por US $\$ 18,00$ teria sofrido um "prejuízo injusto" de US $\$ 40,00$, enquanto o insider que adquiriu tais ações teria obtido um "ganho injusto" no mesmo valor.

Além disso, muitos daqueles que defendem a proibição do insider trading com base no argumento da justiça também entendem que tal proibição se justificaria pelo fato de que utilizar informações privilegiadas é injusto em sua essência, pois os insiders sempre teriam uma vantagem frente à contraparte

\footnotetext{
${ }^{248}$ Tais fatos deram origem ao famoso caso SEC v. Texas Gulf Sulphur, 394 US 976 (1969), julgado pelo Second Circuit Court of Appeals.
} 
da operação. Com efeito, CARLTON e FISCHEL ${ }^{249}$ observam que o argumento da injustiça é tão disseminado e visto como uma verdade absoluta, que diversos doutrinadores sustentam que o insider trading deveria ser proibido mesmo que se mostrasse mais eficiente para o mercado de capitais.

\subsubsection{Market stability theory}

Os defensores da market stability theory sustentam, por sua vez, que as normas coibidoras do insider trading estariam diretamente relacionadas com o desenvolvimento do mercado de capitais enquanto um dos principais meios para captar recursos do público investidor.

Neste sentido, SHEN anota que "it is generally thought that protecting investors from acts of expropriation by management, either in the form of looting or unfair self-dealing, or in the form of exploitation of management's inside information in trading securities, is a precondition to the optimal development of public securities markets" 250 .

Assim, argumenta-se que para que os investidores tenham confiança no mercado de capitais, deve haver alguma garantia de que todos que ali operam estão negociando em condições iguais, pois na medida em que esta igualdade deixa de existir, aqueles que investem suas poupanças no mercado de valores mobiliários perderiam a confiança na transparência e eficiência deste mercado, o que, consequentemente, desencorajaria a entrada de novos investidores e faria com os que já atuam neste mercado migrassem para outras formas de investimento $^{251}$.

\footnotetext{
${ }^{249}$ CARLTON, Dennis. W. e FISCHEL, Daniel.R. The Regulation of Insider Trading. Stanford Law Review, 1983. p. 881.

${ }^{250}$ SHEN, Han. A comparative study of insider trading regulation enforcement in the U.S. and China. Journal of Business \& Securities Law, Vol. 9, No. 1, Fall 2008. p. 42. Disponível em SSRN: http://ssrn.com/abstract $=964548$.

${ }^{251}$ ASHE, Michael e RIDER, Barry. Insider Crime - The New Law. Jordans: United Kingdom, 1993.
} 
Conforme já referido no Capítulo 3 deste trabalho, um dos problemas existentes no mercado de capitais é a assimetria informacional, que pode ter por consequência a já mencionada seleção adversa. Neste contexto, alguns autores entendem que o insider trading tem como uma de suas consequências potencializar os efeitos da seleção adversa, motivo pela qual deve ser proibido. É o que exemplificam SCALZILLI e SPINELLI:

[...] a grande massa de investidores tem acesso apenas às informações divulgadas ao público, ao passo que um restrito número de insiders tem acesso a um manancial de dados com enorme potencial para influir na cotação dos valores mobiliários da companhia. Essas informações devem vir a público de forma a que todos os agentes de mercado tomem conhecimento ao mesmo tempo. Se, ao revés, alguns agentes têm conhecimento prévio dessas situações e as usam para lucrar (em detrimento dos desinformados), esses títulos, aos olhos do investidor comum, poderiam ser tidos como os veículos usados do teorema de Akerlof, ou seja, como bens de baixa qualidade (lemons).

Como há uma grande dificuldade em se saber quais são as companhias com boa ou má qualidade (até porque, no mais das vezes, a utilização de informação privilegiada sequer vem à tona), a tendência seria a de que o mercado as precifique numa média, assim como faz com os carros usados. Essa média, num cenário de uso indiscriminado de informações privilegiadas, tende a ser mais baixa que a dos mercados eficientes, fazendo com que o capital escoe para os mercados mais equitativos ou, mesmo, migre para outras modalidades de investimento "mais seguras", tornando a captação de recursos mais cara e o mercado mais volátil e propenso a oscilações. Essa situação de uso endêmico de informação privilegiada, num estágio bastante avançado, poderia, por hipótese, levar ao desaparecimento do próprio mercado de valores mobiliários. ${ }^{252}$

Para os mencionados autores, a má precificação das ações supostamente gerada pela seleção adversa tenderia a afastar as "boas companhias" do mercado de capitais, que procurariam por formas alternativas de se capitalizar.

\footnotetext{
${ }^{252}$ SCALZILLI, João Pedro; SPINELLI, Luis Felipe. A Racionalidade Econômica do Combate ao Insider Trading: Assimetria de Informação e Dano ao Mercado. Revista de Direito Mercantil, Industrial, Econômico e Financeiro. São Paulo: ${ }^{\circ} 147$, ano XLVI, jul.-set. 2007. p. 50. Em sentido semelhante, Nelson Eizirik sustenta que "as razões de ordem econômica [para se proibir o insider trading] estão relacionadas ao conceito de eficiência na determinação da cotação dos valores mobiliários negociados no mercado de capitais. Considera-se que o mercado é eficiente quando os preços das ações refletem todas as informações sobre as emissoras e os títulos negociados; quanto mais rápida for a reação dos títulos às novas informações, em princípio, mais eficiente será o mercado. $\mathrm{O}$ ideal, pois, é que a cotação dos títulos reflita apenas todas as informações publicamente disponíveis [...]". EIZIRIK, Nelson Laks; GAAL, Ariádna B.; PARENTE, Flávia; HENRIQUES, Marcus de Freitas. Mercado de Capitais - regime jurídico. 2. ed. (revisada e atualizada). Rio de Janeiro: Renovar, 2008. p. 524.
} 
Com isso, o mercado ficaria enfraquecido, perdendo liquidez e aumentado o custo de capital. Ademais, SCALZILLI e SPINELLI argumentam que caso o insider trading fosse permitido, "haveria uma perda de credibilidade generalizada na instituição, afastando aqueles investidores receosos de serem enganados [...]. Essa situação reduziria o volume de recursos negociados, prejudicando, por razões óbvias, a economia como um todo" ${ }^{, 253}$.

\subsubsection{Prejuízos à companhia, aos seus acionistas e aos investidores}

Para alguns autores, a proibição ao uso de informações privilegiadas também se justificaria pelo fato de que o insider trading teria o potencial de prejudicar a companhia, seus acionistas e os investidores. Este prejuízo ocorreria, basicamente, de três formas: (i) atrasando a transmissão das informações dentro da companhia e a divulgação ao público investidor; (ii) interferindo nas operações da companhia; e (iii) incentivando os administradores a tomar riscos excessivos.

O atraso na transmissão das informações entre os administradores da companhia e na sua divulgação ao público seria gerado, pois ao descobrir ou obter uma informação positiva ou negativa sobre a companhia, o administrador tenderia a segurar esta informação pelo tempo que considerasse suficiente para negociar com as ações de emissão da companhia antes de sua divulgação ao público $^{254}$. Como os administradores trabalham em conjunto, sustenta-se ${ }^{255}$ que pode haver uma tendência por parte de um ou mais administradores em atrasar a transmissão da informação aos demais, pois quando outros administradores

\footnotetext{
253 Ibid. p. 51.

254 BRUDNEY, Victor. Insiders, Outsiders, and Informational Advantages under the Federal Securities Laws. Harvard Law Review, Vol. 93, No. 2, (Dez., 1979). p. 334; EASTERBROOK, Frank H. Insider Trading, Secret Agents, Evidentiary Privileges, and the Production of Information. The Supreme Court Review, 1981. p. 333.

${ }^{255}$ HAFT, Robert J. The Effect of Insider Trading Rules on the Internal Efficiency of the Large Corporation. Michigan Law Review, Vol. 80, No. 5 (Abr., 1982), p. 1053
} 
tomam conhecimento de um novo fato relevante, é possível que optem por divulgar imediatamente a informação.

Neste caso, tanto a companhia quanto os investidores como um todo seriam prejudicados pelo atraso na transmissão e divulgação da informação interna corporis, na medida em que tal atraso comprometeria o processo de tomada de decisões dentro da companhia, podendo colocar em risco oportunidades de negócio. Já o atraso na divulgação das informações ao público colocaria os investidores em uma posição de desvantagem, onde estariam negociando com ações que não refletem seu real valor, acentuando o problema da assimetria informacional.

Segundo os defensores da proibição, a prática do insider trading também poderia interferir nos negócios da companhia. O exemplo clássico trazido é aquele em que a companhia se prepara para fazer uma oferta hostil e o administrador da ofertante, sabendo desta intenção, passa a adquirir ações da companhia alvo, fazendo com que o preço destas ações suba ${ }^{256}$, tornando a aquisição mais onerosa, e, em alguns casos, inviabilizando-a ${ }^{257}$.

Por fim, alguns autores sugerem que o insider trading também levaria os administradores a envolverem a companhia em projetos de risco excessivamente elevado. Este argumento está baseado no já mencionado fenômeno da separação entre propriedade e gestão, no qual aqueles que administram e tomam as decisões mais importantes da companhia não são as mesmas pessoas que aportam recursos e estão sujeitas aos riscos do negócio. Assim, de acordo com EASTERBROOK, "they [insiders] may select riskier projects than the shareholders would prefer, because if the risks pay off they

\footnotetext{
${ }^{256}$ Os autores que sustentam essa tese argumentam que, em alguns casos, a negociação pelo insider pode acabar alertando outros participantes do mercado, gerando uma reação em cadeia suficiente para elevar a cotação das ações na bolsa.

${ }^{257}$ EASTERBROOK, Frank H. Insider Trading, Secret Agents, Evidentiary Privileges, and the Production of Information. The Supreme Court Review, 1981. p. 331.
} 
can capture a portion of the gains in insider tradings and, if the project flops, the shareholders bear the loss" 258 .

\subsubsection{O moral hazard e a produção intencional de notícias negativas}

Conforme observado por CARLTON e FISCHEL ${ }^{259}$, diversos autores sustentam que o insider trading também deve ser proibido, pois cria um risco moral ao permitir que os insiders lucrem com notícias ruins sobre a companhia. MANNE sintetiza o argumento, explicando que "the objection basically is that insiders can make as much money trading on bad news as on good news and that therefore they will have as great an incentive to create bad news" 260 .

Determinados autores entendem que, no limite, permitir que os insiders obtenham ganhos com a divulgação de informações negativas faz com que os administradores fiquem indiferentes entre trabalhar para tornar a companhia próspera ou trabalhar para quebra-la.

Outra variação deste argumento é a de que o insider trading cria incentivos para que os insiders disseminem informações falsas sobre a companhia de modo a permiti-los comprar e vender ações a preços artificiais $^{261}$, ou ainda, incentiva os insiders a realizar negócios na bolsa com a única finalidade de estimular artificialmente o preço das ações ou para indicar um falso volume significativo de negócios ${ }^{262}$.

\footnotetext{
${ }^{258}$ Ibid. p. 332.

${ }^{259}$ CARLTON, Dennis. W. e FISCHEL, Daniel.R. The Regulation of Insider Trading. Stanford Law Review, 1983. p. 873.

${ }^{260}$ MANNE, Henry G., Insider Trading and the Stock Market. New York: Free Press, 1966. p. 150.

261 SCHOTLAND, Roy A. Unsafe at Any Price: A Reply to Manne, Insider Trading and the Stock Market. Virginia Law Review, Vol. 53, No. 7 (Nov., 1967). p. 1449-1450.

${ }^{262}$ MANNE, Henry G., Insider Trading and the Stock Market. New York: Free Press, 1966. p. 152.
} 


\subsection{A doutrina a favor da legalização do insider trading}

Vistos os principais argumentos que justificariam a proibição do insider trading, resta, por fim, analisar a posição daqueles autores que defendem a legalização da negociação com base em informações privilegiadas. Para tanto, serão expostos, primeiramente, os principais argumentos apresentados pela doutrina pró-insider para justificar a legalização da prática em questão. Neste ponto, duas proposições serão analisadas: (i) o insider trading melhora - e não piora - a eficiência do mercado, diminuindo o problema da assimetria informacional e contribuindo para uma precificação mais precisa das ações; e (ii) o insider trading se mostraria como um esquema de remuneração eficiente dos administradores da companhia.

Na sequência, serão abordados os principais argumentos utilizados para rebater as teorias que defendem a proibição do insider trading.

Finalmente, serão apresentadas algumas propostas intermediárias de legalização do insider trading, discutidas em trabalhos específicos e não abordadas de forma geral pela maioria dos autores.

\subsubsection{Insider trading e sua contribuição para a eficiência do mercado de capitais}

Como visto, a busca pela eficiência do mercado de capitais é um dos princípios que rege a atuação da CVM e do Conselho Monetário Nacional, conforme definido pelo Art. $4^{\circ}$ da Lei ${ }^{\circ}$ 6.385/76.

Conforme já referido acima, entende-se por "mercado eficiente" aquele onde o preço dos produtos negociados reflete da forma mais rápida e precisa possível todas as informações disponíveis. Logo, para que um mercado apresentasse uma eficiência máxima, todos que nele negociam deveriam ter 
acesso imediato, simultâneo e irrestrito a todas as informações disponíveis sobre aquele produto.

No entanto, no mercado de capitais, por uma série de motivos ${ }^{263}$, não é possível que todos os investidores tenham acesso equânime a todas as informações sobre as companhias emissoras de valores mobiliários. Assim, por mais que a legislação do disclosure busque amenizar este problema, a assimetria informacional sempre irá existir em alguma medida ${ }^{264}$.

Quanto a estas constatações, tanto os defensores da proibição quanto aqueles que defendem a legalização do insider trading não possuem grandes divergências. É o que constata BAINBRIDGE, discorrendo sobre a importância de um mercado onde há uma precificação mais precisa dos ativos nele negociados:

Both Deregulators and Regulators agree society substantially benefits from accurate pricing of securities. The "correct" price of a security is that which would be set by the market if all information relating to the security had been publicly disclosed. Accurate pricing benefits society by improving the economy's allocation of capital investment and by decreasing the volatility of security prices. This dampening of price fluctuation decreases the likelihood of individual windfall gains and increases the attractiveness of investing in securities for risk-adverse investors. The individual corporation also benefits from accurate pricing of its securities through reduced investor uncertainty and improved monitoring of management's effectiveness. Finally, investors as a class benefit by receiving the full value of their investment. ${ }^{265}$

A principal diferença entre aqueles que defendem a proibição do insider trading e aqueles que propõem a sua legalização reside no fato de que enquanto os primeiros entendem que as negociações no mercado de capitais só podem se dar com base nas informações publicamente disponíveis que estejam refletidas no preço das ações, os segundos sustentam que a simetria informacional plena nunca será atingida, logo, seria mais eficiente para o

\footnotetext{
${ }^{263}$ Alguns desses motivos estão elencados no item 3.3 deste trabalho.

${ }^{264}$ DOLGOPOLOV, Stanislav. Insider Trading. The Concise Encyclopedia of Economics. p. 6. Disponível em http://www.econlib.org/library/Enc/insidertrading.html.

265 BAINBRIDGE, Stephen M. The Insider Trading Prohibition: A Legal and Economic Enigma. Florida Law Review, Vol. 38, 1986. p. 9. Disponível em SSRN: http://ssrn.com/abstract=303880.
} 
mercado se aqueles que têm acesso a informações privilegiadas pudessem negociar, pois esta negociação atuaria como mais um canal de informações a ser refletido na cotação das ações.

Esta carga informativa do insider trading tem por consequência principal amenizar o problema da assimetria informacional, aumentando a eficiência do mercado. Isto porque, em determinados casos, a própria legislação societária permite que a companhia não divulgue determinadas informações, quando, por exemplo, tal divulgação possa por em risco interesse legítimo da companhia - é o que prevê o $\$ 5^{\circ}$ do Art. 157 da Lei n ${ }^{\circ} 6.404 / 76^{266}$ e o Art. $6^{\circ}$ da Instrução CVM n ${ }^{\circ} 358 / 02^{267}$. Em outros casos, como já referido acima, pode haver dúvida sobre a materialidade da informação ou quanto ao momento de sua divulgação. Em todas essas situações, haverá uma desigualdade de informações no mercado e as ações não serão precificadas da forma mais precisa pelo mercado.

Considerando que a assimetria informacional é inevitável, sendo em alguns casos produzida, inclusive, pela própria lei, a legalização do insider trading permitira que os insiders, que na grande maioria dos casos tomam conhecimento sobre as informações relevantes da companhia antes do mercado, negociassem com base em tais informações, afetando a cotação das ações e "direcionando-a" para o valor correto, valor este que só seria atingido caso a informação fosse imediatamente divulgada.

\footnotetext{
${ }^{266}$ Art. 157. [...]

$\S 5^{\circ}$. Os administradores poderão recusar-se a prestar a informação ( $\S 1^{\circ}$, alínea e), ou deixar de divulgá-la $\left(\S 4^{\circ}\right)$, se entenderem que sua revelação porá em risco interesse legítimo da companhia, cabendo à Comissão de Valores Mobiliários, a pedido dos administradores, de qualquer acionista, ou por iniciativa própria, decidir sobre a prestação de informação e responsabilizar os administradores, se for o caso.

${ }^{267}$ Art. $6^{\circ}$. [...] os atos ou fatos relevantes podem, excepcionalmente, deixar de ser divulgados se os acionistas controladores ou os administradores entenderem que sua revelação porá em risco interesse legítimo da companhia
} 
Com efeito, as negociações feitas pelos insiders possuem, em si, um grande potencial informativo para o mercado, pois quando os insiders negociam, eles sinalizam ao mercado que o preço das ações tenderá a se mover em uma determinada direção. É o que exemplifica MCGEE:

If a director of General Motors purchases a large quantity of General Motors stock, that act reveals evidence that the stock's price is likely to rise in the near future. Likewise, if the director sells, it is likely that the price will soon fall. A chain reaction will take place as the brokerage firm handling the transaction alerts other brokers and clients, and the stock price will start moving in the correct direction, closer to its true value. There is no need to make a public announcement, because the market reacts almost immediately. Even if the insider is anonymous, an increase (or decrease) in demand for a particular stock will be noticed by the market, and the price will move accordingly. ${ }^{268}$

GILSON e KRAAKMAN ${ }^{269}$ explicam que o efeito que o insider trading produz no preço das ações é um exemplo do que se pode chamar de "derivatively informed trading mechanism", ou em tradução livre, um "mecanismo derivado de negociação informada". De acordo com tais autores, este mecanismo afeta o preço das ações em duas etapas. Na primeira etapa, as pessoas que possuem a informação privilegiada começam a negociar, mas estas negociações iniciais tem um impacto menor sobre a cotação das ações. Posteriormente, terceiros que não possuem acesso direto à informação tomam conhecimento de que insiders estão negociando com as ações da companhia, seja por meio de boatos, conversa entre diversos corretores e, dentre eles, aqueles que executam as ordens de compra e venda dos insiders, ou pela mera observação da movimentação dos insiders. Outras pessoas passam a acompanhar a flutuação do preço das ações e, finalmente, o mercado reage às negociações feitas pelos insiders e gradualmente começa a mover a ação em direção ao preço correto.

\footnotetext{
${ }^{268}$ MCGEE, Robert W. Ethical Issues in Insider Trading: Case Studies. p. 6. Disponível em SSRN: http://ssrn.com/abstract=538682.

${ }^{269}$ GILSON, Ronald J. e KRAAKMAN, Reinier H. The Mechanisms of Market Efficiency. Virginia Law Review. Vol. 70, No. 4, Fifty Years of Federal Securities Regulation: Symposium on Contemporary Problems in Securities Regulation: 1984. p. 630.
} 
O exemplo da Texas Gulf Sulphur dado no início deste capítulo confirma esta hipótese. De acordo com BAINBRIDGE ${ }^{270}$, os insiders da TGS começaram a negociar ativamente com as ações de emissão da companhia quase imediatamente após a descoberta dos depósitos de minério. Consequentemente, durante os quatro meses entre a descoberta e sua divulgação ao mercado, o preço das ações ordinárias da TGS subiu gradualmente até atingir uma diferença de US\$12,00 do preço antes da descoberta. Este aumento no preço das ações, aproximando-o do valor alcançado após a divulgação da informação, teria sido causado principalmente pelas negociações feitas pelos insiders

Corroborando esta constatação, um estudo relativamente recente produzido por AKTAS et. al. ${ }^{271}$ demonstrou por meio de cálculos e dados empíricos que a negociação de ações por insiders antes da divulgação de determinada informação relevante possui uma influência significativa no preço das ações, o que reforça o argumento de que o insider trading contribui para uma precificação mais acurada dos ativos negociados no mercado.

Em termos práticos, isto significa que aqueles investidores que compram e vendem ações de forma contemporânea aos insiders estão pagando um preço mais justo do que se os insiders não pudessem negociar e de fato não negociassem. Mais uma vez utilizando-se do exemplo oferecido no começo deste capítulo, imagine-se que após a descoberta dos depósitos de minério, nenhum funcionário da TGS pudesse negociar e efetivamente não tivesse negociado com as ações de sua emissão.

\footnotetext{
${ }^{270}$ BAINBRIDGE, Stephen M. The Insider Trading Prohibition: A Legal and Economic Enigma. Florida Law Review, Vol. 38, 1986. p. 10. Disponível em SSRN: http://ssrn.com/abstract=303880.

${ }^{271}$ AKTAS, Nihat; DE BODT, Eric e VAN OPPENS, Hervé, Evidence of the Contribution of Legal Insider Trading to Market Efficiency. p. 28. Disponível em http://ssrn.com/abstract=871766. Outros estudos mais antigos corroborando esta conclusão: LIN, Ji-Chai e ROZEFF, Michael S. The Speed of Adjustment of Prices to Private Information: Empirical Tests, 18 J. FIN. RES. 143 (1995); e MEULBROEK, Lisa K. An Empirical Analysis of Illegal Insider Trading, 47 J. FIN. 1661 (1992).
} 
Como visto, as descobertas das reservas de minério foram confirmadas em outubro de 1963, mas sua divulgação ao mercado só foi feita seis meses depois, em abril de 1964. Obviamente, não havia dúvidas de que a divulgação prematura da descoberta colocaria em risco os interesses da companhia, pois além da especulação que a divulgação geraria com as ações, os proprietários das terras onde as reservas estavam localizadas possivelmente exigiriam um preço infinitamente maior do que aquele efetivamente pago pela TGS.

Sem qualquer negociação pelos insiders durante este período de seis meses, o preço das ações não refletiria qualquer informação referente à descoberta das reservas de minério, permanecendo, portanto, próximo aos US\$18,00. Logo, os acionistas que vendessem suas ações neste período receberiam somente US $\$ 18,00$ por suas ações, por mais que, implicitamente, seu valor fosse cada vez maior.

Por outro lado, caso os insiders pudessem negociar livremente, o preço inicial de US $\$ 18,00$ tenderia a ser gradualmente corrigido - como de fato foi -, chegando próximo ao valor que a ação atingiria após a divulgação da informação. Assim, o acionista que antes não conseguiria vender suas ações por mais de US $\$ 18,00$, agora teria uma chance de obter um preço mais próximo ao real valor da ação, digamos, a US\$25,00. Ainda que neste segundo caso o acionista deixasse de ganhar, já que as ações atingiram US\$58,00, não há dúvidas de que ele seria menos prejudicado do que no primeiro caso ${ }^{272}$.

\footnotetext{
${ }^{272}$ BAINBRIDGE desenvolve ainda mais o argumento, também utilizando-se do exemplo da Texas Gulf Sulphur: "Arguably, for example, the TGS shareholders who sold from November through April were not made any worse off by the insider trading that occurred during that period. Most, if not all of these people sold for a series of random reasons unrelated to the trading activities of insiders. The only seller we should worry about is the one that consciously thought, 'I'm going to sell because this worthless company never finds any ore.' Even if such an investor existed, however, we have no feasible way of identifying him. Ex post, of course, all the sellers will pretend this was why they sold. If we believe Manne's argument that insider trading is an efficient means of transmitting information to the market, moreover, selling TGS shareholders actually were better off by virtue of the insider trading. They sold at a price higher than their shares would have commanded but for the insider trading
} 
Por isso, diversos autores, tais como CARLTON e FISCHEL ${ }^{273}$, KELLY et. al. ${ }^{274}$, MORGAN ${ }^{275}$ e $\mathrm{WU}^{276}$, sustentam que a proibição à prática do insider trading tem por efeito bloquear este fluxo de informações que a negociação com base em informações privilegiadas gera, acentuando ainda mais o problema da assimetria informacional.

Outra vantagem do insider trading apontada por CARLTON e FISCHEL é a de que o insider pode ser usado como uma ferramenta para controlar o fluxo de informações refletidas no preço das ações nos casos em que a divulgação é excessivamente onerosa ou não é recomendável. Confiramse as explicações dos autores:

Several reasons explain why communicating information through insider trading may be of value to the firm. Through insider trading, a firm can convey information it could not feasibly announce publicly because an announcement would destroy the value of the information, would be too expensive, not believable, or - owing to the uncertainty of the information - would subject the firm to massive damage liability if it turned out ex post to be incorrect. Conversely, firms also could use insider trading to limit the amount of information to be reflected in price. Controlling the number of traders who have access to information may be easier than controlling how much information gets announced over time. In other words, announcement of information need not to be continuous, while trading on inside information can be. Thus, insider trading gives firms a tool either to increase or to decrease the amount of information that is contained in share prices. 277

Ademais, por mais que a CVM conseguisse identificar e punir toda e qualquer pessoa que se utilizasse de informações privilegiadas para negociar no mercado de capitais, ainda existiriam outros tipos de insider aparentemente impossíveis de serem impedidos, tais como, o insider non-trading e a

activity that led to higher prices." BAINBRIDGE, Stephen M. The Law and Economics of Insider Trading: A Comprehensive Primer. p. 73. Disponível em http://ssrn.com/abstract=261277.

${ }^{273}$ CARLTON, Dennis. W. e FISCHEL, Daniel.R. The Regulation of Insider Trading. Stanford Law Review, 1983.

${ }^{274}$ KELLY, W. A., Jr., NARDINELLI, C. e WALLACE, M.S. Regulation of Insider Trading: Rethinking SEC Policy Rules. The Cato Journal, Fall, 1987, 7(2), p. 441-448.

${ }^{275}$ MORGAN, R. J. Insider Trading and the Infringement of Property Rights. Ohio State Law Journal, 1987, 48, p. 79-116.

${ }^{276}$ WU, H.K. An Economist Looks at Section 16 of the Securities Exchange Act of 1934. Columbia Law Review, February, 1968, 68, p. 260-269.

${ }^{277}$ CARLTON, Dennis. W. e FISCHEL, Daniel.R. The Regulation of Insider Trading. Stanford Law Review, 1983. p 868. 
negociação com base em informações ordinárias (e não informações relevantes) sobre a companhia.

Como efeito, o Art. 13 da Instrução CVM $\mathrm{n}^{\circ}$ 358/02 veda expressamente a negociação de ações por insiders antes da divulgação de fato relevante. No entanto, não há nenhuma vedação para que os insiders simplesmente deixem de comprar ou deixem de vender ações baseados nas mesmas informações privilegiadas, e mesmo que houvesse tal vedação, sua aplicação prática não seria factível.

Considere, por exemplo, que o Diretor A da ABC S.A. possui uma grande quantidade de ações de emissão desta companhia aberta, e antes de uma reunião que aconteceria na parte da tarde, referido diretor estava decidido que iria vender parte de suas ações a $\mathrm{R} \$ 40,00$ para aproveitar uma recente alta no preço das mesmas. No entanto, antes de vender, o Diretor A comparece à reunião da diretoria, onde toma conhecimento de que a XYZ S.A. pretende lançar uma oferta pública de aquisição das ações da ABC S.A. a R $\$ 60,00$ por ação. O Diretor A, utilizando-se de informações ainda não divulgadas ao público, mantém em sua carteira as ações que antes venderia e espera que a oferta pública seja divulgada ao mercado. Após a divulgação, o Diretor A vende suas ações a $R \$ 60,00$ e obtém um lucro expressivo. Obviamente, caso o Diretor A tivesse adquirido mais ações antes da divulgação da informação ao público, ele estaria enquadrado na vedação legal ao insider trading. No entanto, ao não vender suas ações a $R \$ 40,00$, o Diretor A não violou qualquer norma, apesar de ter gerado no mercado o mesmo efeito que seria gerado caso tivesse comprado ações, uma vez que ao não vender suas ações, alguém deixou de compra-las a $\mathrm{R} \$ 40,00$ e de obter o lucro que foi obtido pelo Diretor A. 
Logo, em termos práticos, o insider trading e o insider non-trading geram exatamente os mesmos efeitos para o mercado. É o que constata MANNE:

In fact, many people who exploit new information do not buy additional stock; rather, they simply do not sell. If the stock is already in their portfolio, it may be sold or not as conditions dictate. However, with inside information, they know when not to sell any of their present holdings. Refraining from selling stock that would otherwise have been sold has exactly the same economic effect on market price as a decision to buy that same number of shares [...].

The upshot of all this is that people can make abnormal profits in the stock market simply by knowing when not to buy and when not to sell. They will not make as much perhaps as if they could trade on the information more efficiently, but nonetheless they will still make supra-competitive returns. And this is a form of insider trading that no one can do anything about. It may also be the dominant method of using inside information. ${ }^{278}$ (grifado)

Ademais, esta aplicação parcial da proibição do insider trading - isto é, normas que proíbem o insider trading, mas que, por questões práticas, não proíbem o insider non-trading - podem gerar efeitos adversos no mercado. Imagine-se, por exemplo, que os diretores da ABC S.A. estão discutindo lançar uma oferta pública para que a ABC S.A. passe a controlar ou a XYZ S.A. ou a 123 S.A. Os diretores possuem uma posição considerável em ações na XYZ S.A., não possuem ações da 123 S.A. e sabem que a oferta pública afetará positivamente o preço das ações de qualquer das duas companhias. Neste cenário, cientes de que a aquisição de ações da 123 S.A. se enquadraria na definição de insider trading, os diretores teriam um incentivo maior em decidir pela aquisição do controle da XYZ S.A., por mais que para a ABC S.A. esta operação fosse menos benéfica que a aquisição do controle da 123 S.A. ${ }^{279}$

Além do insider non-trading, há ainda outra modalidade de negociação com base em informações confidenciais que dificilmente poderia ser detectada

\footnotetext{
${ }^{278}$ MANNE, Henry G. Insider trading and property rights in new information. Cato Journal, Vol. 4, No. 3, 1985. p. 938.

279 JR., William A. Kelly; NARDINELLI, Clark; e WALLACE, Myles S. Regulation Of Insider Trading: Rethinking SEC Policy Rules. Massachusetts: Cato Journal (Vol.7, n²), 1987. p. 446.
} 
e punida, qual seja a negociação com base em pequenas informações sobre assuntos ordinários da companhia. Com efeito, KELLY et. al. observam que "gains from high visibility events represent only the tip of the iceberg of insider trading gains". Confira-se a explicação dos autores:

One source of insider gains is trading on the basis of ordinary insider information. Ordinary information could include inside knowledge of the ability of managers. For example, an executive might know that a new chief executive officer is extraordinarily competent and buy stock on that knowledge, gaining from the appreciation brought about by the new boss. A feud between two important corporate officers could lead to gains to insiders who sell on the expectation that the feud will affect the firm's performance. Countless other bits of information can be used by insiders to outperform the market. Gains from ordinary inside information are not as spectacular as those arising from advance information on a hostile takeover bid. Yet, the aggregate gains from ordinary insider trading may well exceed gains from the more glamorous bombshell trades. ${ }^{280}$

De fato, como visto no Capítulo 4 deste trabalho, as normas de combate ao insider trading proíbem a negociação com base em informações relevantes, sendo estas consideradas aquelas informações que podem influir de modo ponderável na cotação dos valores mobiliários ou na decisão dos investidores de comprar ou vender ações da companhia. Logo, as demais informações que não se enquadram neste conceito poderiam ser utilizadas pelos insiders sem que restasse configurada qualquer violação às normas existentes.

Assim, proibir o insider trading pode se mostrar não só como uma medida prejudicial tanto aos investidores quanto à eficiência do mercado como um todo, mas também como uma forma ineficaz, custosa e falha de alcançar um mercado de capitais mais eficiente, tendo em vista que ainda que algumas formas de insider sejam parcialmente coibidas, outras sempre continuarão a existir livres de qualquer punição.

${ }^{280}$ Ibid. p. 443. 


\subsection{2. $O$ insider trading como um eficiente mecanismo de remuneração dos administradores}

A ideia do insider trading como um mecanismo de remuneração dos administradores da companhia foi sugerido pela primeira vez por Henry G. Manne, no já mencionado livro "Insider Trading and the Stock Market".

Importante destacar que o "administrador"281 a que se refere Manne não é qualquer administrador, mas sim aqueles indivíduos que contribuem com a produção de "novas informações valiosas para a companhia",282, ou, em outras palavras, aqueles que contribuem para a elaboração e execução de novos projetos com potencial lucrativo para a companhia. Normalmente, estes administradores são pessoas que ocupam cargos na alta administração, tais como o conselho de administração e, principalmente, a diretoria, órgão onde estão os profissionais que, em regra, tomam as decisões operacionais da companhia.

De acordo com BAINBRIDGE, "a remuneração do administrador deve estar razoavelmente relacionada com o valor de sua contribuição de modo a dar a ele incentivo para produzir mais informações" ${ }^{283}$. Neste ponto, MANNE observa que a grande peculiaridade da remuneração deste tipo de administrador advém do fato de que o resultado de suas contribuições é, na maioria das vezes, indeterminável. Isto porque, segundo o autor, "true

\footnotetext{
${ }^{281}$ O termo "administrador" foi uma tradução adaptada da expressão "entrepreneur", que em uma tradução literal e mais precisa seria traduzido como "empresário". No entanto, conforme se verá adiante, o conceito de "entrepreneur" pensado por Manne se aproxima mais, no Brasil, do conceito de administrador, notadamente aqueles que atuam no dia a dia operacional da companhia e fazem parte das tomadas de decisão mais importantes.

${ }^{282}$ MANNE, Henry G., Insider Trading and the Stock Market. New York: Free Press, 1966. p. 116.

283 BAINBRIDGE, Stephen M. The Insider Trading Prohibition: A Legal and Economic Enigma. Florida Law Review, Vol. 38, 1986. p. 12. Disponível em SSRN: http://ssrn.com/abstract=303880.
} 
innovation cannot be planned and budgeted in advance. An individual cannot be hired to perform ' $x$ ' amount of entrepreneurial service",284.

Assim, salários, bônus, participação nos resultados e planos de opções de compra de ações não seriam formas eficientes de remunerar estes administradores. Cada uma dessas modalidades apresenta falhas que não remuneram de forma adequada a inovação trazida por tais profissionais. É o que explica MANNE:

Salary is appropriate only to purchase a known service in the labor market. The parties to the agreement must have a fairly clear understanding of what the job entails and what the skills of the employee is relative to others in the same market. This is equally true of the lowly bookkeeper and the president of the giant company. If it is known what job either is to do in order to maintain or improve the company's earning, no innovational activity is being contracted for.

\section{$[\ldots]$}

The introduction of a profit-sharing plan may constitute pure entrepreneurial compensation, but only the value of the participation at exactly the time it is granted can constitute entrepreneurial compensation. The operation of this or any other profitsharing plan fails to meet our necessary conditions. The effect of such a plan is to give the recipient a proprietary stake in the business. He is then an investor and a risk-taker, and his annual return will be that of a capitalist, regardless of how it is computed. The initial, discounted value of his participation in the plan may constitute entrepreneurial profits, but subsequent withdrawals will constitute interest on his investment.

Also, standard accounting techniques for determining profits simply cannot isolate the elements reflecting an entrepreneurial contribution. Profit-sharing plans tend to make employees emphasize current paper profits, as opposed to investments maximizing future returns.

\section{$[\cdots]$}

The bonus has to be decided upon unilaterally by someone other than the recipient. A certain degree of bargaining may occasionally occur, but the entrepreneur will tend to value his contribution to the company higher than others will. Furthermore, the bonus has to be determined on an annual basis, while the effects of any given innovation may be very prolonged. That makes it extremely difficult to assess accurately the value of any particular innovation.

\footnotetext{
${ }^{284}$ MANNE, Henry G., Insider Trading and the Stock Market. New York: Free Press, 1966. p. 133.
} 
Bonuses are not apt to be forthcoming in years when the company has actually lost money, even though the value of the innovation was substantial and without it the company might have shown greater losses.

$[\ldots]$

Apart from the numerous conditions and restrictions on the use of stock options [...], options must be granted prior to the innovation to serve the purpose at hand. If they are granted after the information is known but before disclosure, the economic effect is precisely that of a bonus equal to the anticipated gain, and all the valuation problems inherent in the bonus scheme are again present. But if the option is granted before the innovation, there is no way of knowing whether the potential gain is appropriate or not, because it will vary with the number of share covered. [...] Stock options are inefficient devices for exploiting information because they are generally not mobile or liquid assets. To gain any tax advantage, they must be nontransferable, and many companies require the executive to hold the stock for a certain period of time after exercise. Stock options are also not flexible devices for insiders' quick use. Shareholders usually ratify a stock-option plan before it becomes effective, and this can be very time-consuming. ${ }^{285}$

Neste contexto, o insider trading representaria uma forma mais eficiente e precisa de remunerar os administradores por suas inovações e contribuições à companhia e, consequentemente, pelas informações que são "geradas" e transmitidas ao mercado a respeito de tais inovações e contribuições ${ }^{286}$. Estando os administradores livres para negociar com ações de emissão da companhia antes da divulgação de um fato relevante para o qual tais administradores contribuíram, permite-se que eles obtenham uma remuneração que, em tese, corresponde ao valor de tal informação. Esta forma de compensação não apresenta os problemas normalmente verificados nas demais modalidades acima descritas.

\footnotetext{
${ }^{285}$ Ibid. pp. 134-137.

${ }^{286}$ O processo de "geração" da informação a que se refere Henry G. Manne está relacionado à cadeia de eventos que culminam com a transmissão da informação ao mercado e à consequente influência no preço das ações. Assim, tomando-se como exemplo o já mencionado caso da TGS, os administradores que participarem do processo de descoberta e exploração das reservas de minério, decidindo onde, quando e de que forma extrai-los, contribuíram para que a informação sobre tal descoberta fosse gerada, pois não fosse sua capacidade de conduzir este processo, a companhia poderia nunca ter encontrado as reservas. Assim, por terem contribuído na geração de valor para a companhia, contribuição essa que seria transmitida ao mercado por meio de um fato relevante, diz-se que os administradores contribuíram para a "geração" desta informação e, por isso, fariam jus a uma compensação equivalente o valor de tal informação.
} 
Não obstante, alguns defensores da proibição do insider trading argumentam que os administradores não poderiam gozar de nenhuma vantagem sobre os demais acionistas da companhia. MANNE observa, no entanto, que este argumento assume de maneira equivocada que apenas os retornos oriundos da participação no capital social da companhia seriam apropriados para qualquer um que detém ações, seja ele administrador ou não.

O autor, então, contra-argumenta, afirmando que não se pode exigir que um administrador participe dos ganhos da companhia que administra somente desta forma, pois a mera detenção de ações da companhia não dá a ele nenhum tipo de remuneração especial por suas habilidades como um gerador de informações valiosas, mas, ao contrário, apenas garante que o insider terá o mesmo retorno pelo seu investimento que outros acionistas, que em nada contribuíram para a geração da informação valiosa, mas que, por outro lado, obtém ganhos quando o valor desta informação é incorporado ao preço da ação. $^{287}$

Os argumentos de Henry G. Manne demonstrando como o insider trading poderia representar um mecanismo de remuneração eficiente para os administradores foram posteriormente refinados por CARLTON e FISCHEL, que sustentam que a utilização do insider trading como um mecanismo de remuneração também seria uma ferramenta eficaz para atenuar os chamados “custos de agência" (agency costs) ${ }^{288}$.

Tendo em vista que os administradores são agentes (agents) cujas ações não podem ser perfeitamente monitoradas pelos acionistas (principals), os administradores teriam a possibilidade e o incentivo para tomar medidas no seu melhor interesse, mas não necessariamente no melhor interesse da companhia.

\footnotetext{
${ }^{287}$ Ibid. p. 141.

${ }^{288}$ CARLTON, Dennis. W. e FISCHEL, Daniel.R. The Regulation of Insider Trading. Stanford Law Review, 1983. p. 869.
} 
Por isso, faz-se necessário que a companhia desenvolva mecanismos de fiscalização e incentivo para que os administradores sempre atuem alinhados com os interesses dos acionistas.

No entanto, este monitoramento constante dos administradores gera diversos custos, conhecidos como "custos de agência". Ademais, os mecanismos desenvolvidos para alinhar os interesses de administradores e acionistas, a saber, os salários, bônus, participação nos lucros e planos de opção de compra de ações, além de apresentarem os problemas já descritos acima, envolvem um constante custo de renegociação, já que, como visto, o valor de uma inovação não pode ser mensurado ex ante.

Neste contexto, o insider trading também se mostraria como uma ferramenta útil para incentivar os administradores a atuarem no melhor interesse da companhia, diminuindo os custos de agência. É o que explicam CARLTON e FISCHEL:

Insider trading may present a solution to this cost-of-renegotiation dilemma. The
unique advantage of insider trading is that it allows manager to alter his
compensation package in light of new knowledge, thereby avoiding continual
renegotiation. The manager, in effect, "renegotiates" each time he trades. This in turn
increases the manager's incentive to acquire and develop valuable information in the
first place (as well as to invest in firm-specific human capital). If a manager observes
a possible valuable investment for the firm - such as a potential value-increasing
merger or a possible new technology - he will more inclined to pursue this
opportunity if he is rewarded upon success. Insider trading is one such reward. [...]
The insider trading alternative reduces the uncertainty and cost of renegotiation and
this increases the incentives of managers to produce valuable information. Moreover,
because managers themselves determine the frequency of "renegotiations", they can
tailor their compensation scheme to their particular attitudes towards risks. CARLTON e FISCHEL também rebatem o argumento trazido pelos contra insiders de que o insider trading permite que os administradores se beneficiem em detrimento dos acionistas, afirmando que pelo fato de o insider trading se apresentar como um mecanismo eficiente de remuneração dos 
administradores, tanto os insiders como os acionistas se beneficiariam caso o insider trading fosse permitido. Veja-se a explicação dos autores:

Nobody would argue seriously that salaries, options, bonuses and other compensation devices allow insiders to profit at the expense of outsiders because these sums otherwise would have gone to shareholders. Compensating managers in this fashion increases the size of the pie, and thus outsiders as well as insiders profit from the incentives managers are given to increase the value of the firm. Insider trading does not come "at the expense of" outsiders for precisely the same reason. ${ }^{289}$

Por fim, CARLTON e FISCHEL reconhecem que nenhum mecanismo de remuneração é perfeito. Os administradores podem obter ganhos com um plano de opção de compra de ações, por exemplo, por força de uma alta no preço das ações causada por questões de mercado sem qualquer ligação com sua produtividade - isto é, a ação teria atingido este preço independentemente do incentivo gerado pelo plano de opções. Esta possibilidade, porém, não prova que planos de opção são completamente ineficientes.

Assim, concluem mencionados autores, a questão relevante não é saber se o insider trading, planos de opção ou outras formas de remuneração funcionam perfeitamente, mas sim entender se em um cenário de remuneração imperfeita e monitoramento custoso, os mesmos benefícios podem ser obtidos a custos baixos através de outras modalidades de remuneração. Logo, a menos que isso possa ser empiricamente demonstrado, é impossível concluir que o insider trading é um mecanismo de remuneração ineficiente. ${ }^{290}$

\subsubsection{Falhas da unfair advantage theory}

Como visto, os defensores da unfair advantage theory sustentam, basicamente, que pelo fato de haver uma assimetria informacional entre o insider e a outra ponta da operação, qualquer negociação nestes termos seria

\footnotetext{
${ }^{289}$ Ibid. p. 881.

${ }^{290}$ Ibid. p. 878.
} 
injusta, pois caso o terceiro detivesse as mesmas informações detidas pelo insider, provavelmente não faria o negócio.

Este argumento, no entanto, é falho por diversos motivos. Em primeiro lugar, conforme visto anteriormente, a simetria informacional completa é, na prática, impossível, seja porque em alguns casos a própria lei permite que a informação não seja divulgada pela companhia, seja porque os diversos investidores possuem capacidades diferentes para interpretar a mesma informação.

Além disso, nas operações havidas em bolsa, a contraparte é, em regra, desconhecida, não sendo possível saber se se está operando com um insider ou não. Neste ponto, confiram-se as observações de YEO:

In addition, it is often the case that parties dealing with insiders usually do not even know who they are dealing with as securities transactions are generally conducted on a random matching basis. Such a purchaser or seller engages in the transaction without being influenced to do so by the insider. There does not therefore appear to be any basis for imposing a duty on the insider vis-à-vis a person who is not privy to the inside information. ${ }^{291}$

No mesmo sentido é a opinião de MCGEE:

A typical case of insider trading occurs when a buyer with inside information calls his stock broker and tells him to buy, knowing that the stock price is likely to rise as soon as the inside information becomes public. In this case, the buyer does not deceive the seller into giving up property. Indeed, the buyer does not even know who the seller is, and the seller would have sold anyway, anonymously, through the same broker. The seller's action would have been the same whether an inside trader was the other party to the transaction or not. If the inside trader had not purchased the stock, someone else would have. Yet this "someone else" would not be accused of reaping unjust profits, even if the identical stock was purchased for the same price the insider would have paid. ${ }^{292}$

Logo, pouco importa se na outra ponta da operação há um insider e se este insider possui ou não informação privilegiada, pois a menos que o terceiro

\footnotetext{
${ }^{291}$ YEO, Victor CS. A Comparative Analysis of Insider Trading Regulation - Who is liable and what are the sanctions? p. 7. Disponível em http://ssrn.com/abstract=260884.

${ }^{292}$ MCGEE, Robert W. Ethical Issues in Insider Trading: Case Studies. pp. 3-4. Disponível em SSRN: http://ssrn.com/abstract=538682.
} 
tenha sido propositalmente induzido a negociar determinada ação (por meio de coação ou fraude), aquela operação aconteceria figurando o insider como contraparte do negócio ou não. Em outras palavras: a negociação não teria sido mais ou menos justa se o terceiro que negocia com o insider tivesse negociado com um outsider. A assimetria informacional continuaria existindo, o terceiro teria vendido pelo mesmo preço, e o outsider teria comprado pelo mesmo preço. É o que conclui MANNE:

The most fundamental economic proposition in the whole topic of insider trading is that no shareholder is harmed by a rule of law that allows exploitation of nonpublicized information about shares of publicly traded corporations. The naïve argument in defense of the SEC's position on this subject is that if the shareholder had the information (good news) the insider had, he would not sell his shares [...]. The statement compares the behavior of an "outside" shareholder who is in possession of valuable information with one who is not. Unfortunately for the proponents of this view, however, that is not the relevant comparison. The real question is whether the person waiting to sell shares for exogenous reasons would behave differently before the information has been disclosed if insiders are or are not allowed to trade on the information. Obviously every shareholder would like to have access to more wealth. But there is no reason to believe that the rule about insider trading will have any effect on the time of this sale, which is the critical issue in the matter. Obviously the argument demonstrates no injury to any prepublication interest that should be protected. ${ }^{293}$ (grifado)

Neste sentido, a grande falha do argumento de que os investidores pagam o preço "errado" pelas ações quando negociam com insiders reside no fato de que seus defensores assumem uma situação sem insider trading na qual as informações são divulgadas antes do que seriam caso o insider trading fosse permitido. Isto é, esta tese assume que o momento da divulgação da informação relevante será exatamente o momento no qual o primeiro insider negociaria caso fosse permitido, enquanto que uma regra permitindo o insider trading resultaria na divulgação da informação somente depois da negociação pelo insider.

\footnotetext{
${ }^{293}$ MANNE, Henry G. Insider Trading and Property Rights in New Information. Cato Journal, Vol. 4, No. 3, 1985. pp. 933-934.
} 
No entanto, conforme observado por MANNE, "they are comparing the real, imperfect world of insider trading to a never, never land of perfect solutions to all problems, especially enforcement. They assume that a rule against insider trading is the equivalent of a full and timely disclosure rule perfectly enforced". ${ }^{294}$

Em verdade, alguns autores, como DEMSETZ, sustentam que a proibição do insider trading tende a tornar o sistema do full and fair disclosure menos eficiente, atrasando a divulgação tempestiva das informações:

It is not clear that attempts to discourage insider trading will shorten the time between the acquisition of valuable market knowledge by the firm and its revelation to shareholders and the general public. By increasing the cost of using the direct and obvious methods of capturing some of the value of this information, the SEC will encourage insiders to rely in greater degree on the less direct and more timeconsuming methods. The possible or probable result will be to lengthen the time period during which insiders attempt to keep really valuable information secret. Inside information that can be used profitably only if direct trading methods are used may become available sooner or later depending on whether managers decide to reveal the knowledge of confine it to the next quarterly or annual report. ${ }^{295}$

Por outro lado, legalizar o insider trading faria com que as informações fossem divulgadas de forma mais rápida, contribuindo para a melhora da divulgação ampla e completa das informações. É o que explica MANNE:

People with accurate and reliable information will generally be well advised not to risk their almost certain profit by delaying the exploitation of that information. That is, their incentive will be to move very quickly, with whatever resources are at their command, to profit from their information. Even if news were 100 percent reliable and correct, with each additional minute, hour, or day the probability of a new event occurring to cause a decline in the same stock's price rises rapidly. It will generally be a poorer but wiser insider who fails to take immediate advantage of reliable information. It should be noted that disclosure must in any event occur fairly shortly after insider trading if the insider is to make any profit. While his own trading and that of other traders may drive the price up, it would ordinarily be extremely expensive to maintain such a high price unless new information justifying it is disclosed. In the short run, then, insider trading may have the same effect as

\footnotetext{
${ }^{294}$ MANNE, Henry G. Insider Trading and the Law Professors. 23 Vand. L. Rev. 547 (1969-1970). p. 552.

${ }^{295}$ DEMSETZ, Harold. Perfect competition, Regulation and the Securities Market. Economic Policy and the Regulation of Corporate Securities I (H. Manne ed. 1969). p. 14.
} 
disclosure, but in the longer run, unless there is very substantial money supporting the market, disclosure will have to occur very quickly. ${ }^{296}$

Além disso, como visto no item 6.2.1, caso o insider trading fosse permitido, o preço da ação tenderia a se mover na direção correta, aproximando-se da cotação que seria atingida após a divulgação da informação. Assim, o terceiro que compra e vende ações em um mercado onde o insider trading é permitido celebra negócios a preços mais justos e mais próximos do seu real valor.

A decorrência lógica deste raciocínio, observa BAINBRIDGE, analisando a proibição do insider trading nos Estados Unidos, é que o prejuízo sofrido pelo investidor não está na negociação com o insider em si, mas antes disso, na assimetria informacional que sempre irá existir:

The information asymmetry between insiders and public investors arises out of the federal securities laws' mandatory disclosure rules, which allow firms to keep some information confidential even if it is material to investor decision-making. Unless immediate disclosure of material information is to be required, a step the law has been unwilling to take, there will always be winners and losers in this situation. Irrespective of whether insiders are permitted to inside trade or not, the investor will not have the same access to information as the insider. It makes little sense to claim that the shareholder is injured when his shares are bought by an insider, but not when they are bought by an outsider without access to information. To the extent the selling shareholder is injured, his injury thus is correctly attributed to the rules allowing corporate nondisclosure of material information, not to insider trading. ${ }^{297}$ (grifado)

Alguns defensores da proibição do insider trading ${ }^{298}$, aceitando a premissa de que os insiders movem o preço das ações, argumentam que esta oscilação no preço teria o potencial de induzir os investidores a realizarem negócios ruins, que não teriam sido realizados caso os insiders fossem

\footnotetext{
${ }^{296}$ MANNE, Henry G. Insider Trading and the Law Professors. 23 Vand. L. Rev. 547 (1969-1970). p. 568.

297 BAINBRIDGE, Stephen M. Insider Trading: An Overview. p. 12. Disponível em http://ssrn.com/abstract=132529.

${ }^{298}$ DOOLEY, Michael P. Enforcement of Insider Trading Restrictions. Virginia Law Review. Vol. 66, No. 1 (Fev., 1980). p. 34; SCHOTLAND, Roy A. Unsafe at Any Price: A Reply to Manne, Insider Trading and the Stock Market. Virginia Law Review. Vol. 53, No. 7 (Nov., 1967). pp. 1447-1448.
} 
proibidos de negociar. Mais uma vez, este argumento parece não se sustentar diante de uma análise mais cuidadosa.

Conforme explica BAINBRIDGE, "the inducement argument is further flawed because many transactions would have taken place regardless of the price changes resulting from insider trading". E continua:

Investors who would have traded irrespective of the presence of insiders in the market benefit from insider trading because they transacted at a price closer to the "correct" price; i.e., the price that would prevail if the information were disclosed. In any case, it is hard to tell how the inducement argument plays out when investors are examined as a class. For any given number who decide to sell because of a price rise, for example, another group of investors may decide to defer a planned sale in anticipation of further increases. ${ }^{299}$ (grifado)

Outro ponto falho da unfair advantage theory é que para que os insiders fossem impedidos de obter qualquer "vantagem injusta" sobre os acionistas, seria preciso criar uma regra onde os insiders só pudessem negociar com as ações da companhia depois que as informações privilegiadas já tivessem sido refletidas de forma completa no preço das ações.

Utilizando-se do exemplo trazido no começo deste capítulo, para que a proibição do insider trading com base na unfair advantage theory pudesse de fato gerar os efeitos pretendidos, os insiders da Texas Gulf Sulphur deveriam ter sido impedidos de negociar desde o momento da descoberta das reservas de minério até o momento em que esta informação já estivesse completamente refletida no preço das ações, suponha-se, quando as ações atingissem US\$58,00. No entanto, como visto, as ações da TGS só atingiram a cotação de US\$58,00 um mês após a divulgação da descoberta.

Por razões óbvias, uma regra que buscasse impedir os insiders de negociar enquanto a informação não estivesse plenamente refletida no preço da ação - isto é, no caso da Texas Gulf Sulphur, enquanto as ações não atingissem

299 BAINBRIDGE, Stephen M. Insider Trading: An Overview. p. 12. Disponível em http://ssrn.com/abstract=132529. 
US\$58,00 - seria extremamente difícil de ser fiscalizada e aplicada, seja porque o período de vedação à negociação (black-out period) poderia se estender por meses, seja porque, em alguns casos, seria muito difícil determinar o ponto em que o preço da ação já estaria refletindo de forma completa o valor da informação divulgada.

Desta forma, conforme muito bem observado por $\mathrm{MANNE}^{300}$, uma lei que regula o insider trading permitindo que o insider adquira a ação imediatamente após o disclosure a, por exemplo, US\$18,10, mas que proíbe que o insider adquira a mesma ação antes do disclosure a US\$18,00, não se mostra eficaz naquilo que propõe.

Em outras palavras, e utilizando-se de um exemplo prático: os administradores de uma companhia aberta, tendo conhecimento de uma informação relevante ainda não divulgada, e sabendo que não podem negociar com ações da companhia enquanto tal informação não se torne pública, poderiam esperar a divulgação da informação ao mercado para, no minuto seguinte, ligar para seu corretor e solicitar que fossem adquiridas ou vendidas (dependendo da natureza da informação) as ações da companhia. Com isso, o administrador provavelmente conseguiria obter um preço pelas ações que ainda não reflete de forma completa o valor da informação recém divulgada.

Por todos estes motivos, conclui MANNE, "an effective rule against insider trading would require that insiders abstain from trading during some period after public disclosure" 301.

Assim, sob o ponto de vista da eficiência econômica, o argumento da "justiça" simplesmente não se sustenta e, portanto, não pode ser usado para justificar a proibição - e as respectivas sanções - ao insider trading da forma

\footnotetext{
${ }^{300}$ MANNE, Henry G., Insider Trading and the Stock Market. New York: Free Press, 1966. p. 87.

301 Ibid. p. 88.
} 
como existem no Brasil e em outros países do mundo. É o que conclui MCGEE:

Comparative advantage works to the benefit of the vast majority of the population. It allows specialization and division of labor, which Adam Smith pointed out in his pin factory example leads to far greater efficiency, higher quality and lower prices. Not allowing individuals to use their special talents harms the entire community as well as the individuals who are being held back by some government law or regulation. Forcing a level playing field on people is always harmful because it reduces efficiency and violates rights. Using the level playing field argument to prevent individuals from using their insider knowledge for personal gain does not hold up under analysis. If insider trading is to be made illegal and if inside traders are to be punished, some other justification must be found. (grifado) ${ }^{302}$

\subsubsection{Falhas da market stability theory}

Para os defensores da market stability theory, o insider trading tornaria o mercado menos eficiente, na medida em que acentuaria o problema da assimetria informacional e abalaria a confiança dos investidores. Assim como a unfair advantage theory, a market stability theory possui uma série de falhas que comprometem a sua força como base para sustentar a proibição e as sanções à negociação com base em informações privilegiadas.

Em primeiro lugar, tendo em vista que, conforme explicado acima, os investidores não são prejudicados pelos insiders, mas, ao contrário, se beneficiam quando este grupo de pessoas negocia, é difícil enxergar como os investidores perderiam a confiança na integridade do mercado de capitais.

Com efeito, MCGEE observa que qualquer sentimento de raiva que os investidores possam sentir da prática do insider trading parece vir não da perda de confiança no mercado, mas sim da inveja sentida pelo maior acesso que os insiders têm às informações. De acordo com o autor, muitas pessoas sentem-se ressentidas ao verem outras ganharem dinheiro com pouco esforço (visível). Assim, tais pessoas preferem que os insiders sejam punidos, não por terem

\footnotetext{
${ }^{302}$ MCGEE, Robert W. Ethical Issues in Insider Trading: Case Studies. p. 12. Disponível em SSRN: http://ssrn.com/abstract=538682.
} 
obtido seu lucro de forma ilícita, mas porque foram capazes de lucrar enquanto a pessoa invejosa não o foi:

[Envy] encompasses the idea that people who have more property than you do should have it taken away from them. The fact that they might have earned it only adds to the ill feeling, and the fact that they might have earned it with little effort is worse yet. Inside trading fits this scenario quite well. Inside traders can earn in a few weeks what it takes most people several lifetimes to earn. They earn it with little visible effort. There is something 'shady' about how they earn it. The information is secret and they often obtain it through the good old boy network, which is seen as racist and sexist (white and male). The fact that the gain was earned without violating anyone's rights is totally ignored, as is the fact that the inside trader's actions have probably benefited society by helping the market operate more efficiently. ${ }^{303}$

Corroborando estas conclusões, BAINBRIDGE ${ }^{304}$ aponta que uma pesquisa realizada pela revista Business Week indicou que 52\% dos participantes gostariam que o insider trading permanecesse proibido. No entanto, visando identificar se este resultado advinha da perda de confiança dos investidores no mercado ou da mera inveja sentida por eles em relação aos insiders, uma pesquisa realizada pela empresa Harris Interactive apontou que 55\% dos participantes responderam que utilizariam informações privilegiadas caso tivessem a oportunidade. Dos que disseram que não negociariam, 34\% afirmaram que só não o fariam por temerem que a dica (tip) fosse imprecisa, enquanto somente $35 \%$ disseram que não utilizariam informações privilegiadas por acharem a prática "errada”. A partir destes dados, BAINDRIGE conclui:

Here lies one of the paradoxes of insider trading. Most people want insider trading to remain illegal, but most people (apparently including at least some of the former) are willing to participate if given the chance to do so on the basis of accurate information. This paradox is central to evaluating arguments based on confidence in the market. Investors that are willing to inside trade if given the opportunity obviously have no confidence in the integrity of the market in the first instance. Any anger they feel over insider trading therefore has nothing to do with a loss of

\footnotetext{
${ }^{303}$ MCGEE, Robert W. Ethical Issues in Insider Trading: Case Studies. p. 12. Disponível em SSRN: http://ssrn.com/abstract $=538682$.

${ }^{304}$ BAINBRIDGE, Stephen M. The Law and Economics of Insider Trading: A Comprehensive Primer. p. 73. Disponível em http://ssrn.com/abstract=261277.
} 
confidence in the integrity of the market, but instead arises principally from envy of the insider's greater access to information. ${ }^{305}$ (grifado)

Ademais, o argumento sobre a estabilidade do mercado não se sustenta diante da excelente performance apresentada pelo mercado de capitais no período imediatamente posterior à divulgação dos grandes escândalos envolvendo o uso de informações privilegiadas na década de 1980 nos Estados Unidos. Primeiramente, BAINBRIDGE aponta que se os investidores realmente acreditavam que a SEC era capaz de livrar o mercado do insider trading, estas pessoas estavam "beyond mere legal help"306. Logo, BAINBRIDGE conclui que estando os investidores cientes que o insider trading era prática comum no mercado e que tal prática nem sempre era detida pela SEC, o bom desempenho do mercado de capitais norte-americano durante este período sugere que estes episódios não abalaram a confiança do investidor. $^{307}$

Somam-se a estes argumentos aqueles trazidos por CARLTON e FISCHEL. Conforme observado por tais autores, o argumento da confiança do investidor e estabilidade/liquidez do mercado não se sustenta quando se constata que o mercado de capitais norte-americano (i) era bem sucedido pré1933 (antes da regulação do insider trading); (ii) era bem sucedido pré-1960 (antes da extensão judicial do conceito de insider trading); e (iii) é atualmente bem sucedido, não obstante a existência do insider trading legal e, muito possivelmente, o ilegal. ${ }^{308}$

Ademais, CARLTON e FISCHEL observam que "if insiders could not trade, the gains to noninsiders from discovering nonpublic information would

\footnotetext{
${ }^{305}$ Ibid. p. 74.

306 BAINBRIDGE, Stephen M. Insider Trading: An Overview. p. 13. Disponível em http://ssrn.com/abstract $=132529$.

${ }^{307}$ BAINBRIDGE, Stephen M. The Law and Economics of Insider Trading: A Comprehensive Primer. p. 74. Disponível em http://ssrn.com/abstract=261277.

${ }^{308}$ CARLTON, Dennis. W. e FISCHEL, Daniel.R. The Regulation of Insider Trading. Stanford Law Review, 1983. p. 880.
} 
be higher and investors would have an incentive to expend resources to uncover such information". E concluem:

In fact, the only effect a ban on insider trading might have is that those with better access to information, such as brokers, would reap some of the gains from inside information. While this may be inefficient because brokers can become informed only at a higher cost, the informed-uninformed trader problem remains. Smart brokers, in other words, cause the same problem as smart insiders. Uninformed traders who know they are uninformed should not trade in either situation. That trade occurs suggests that traders either do not believe they are uninformed or realize that enough informed trading occurs for the prevailing prices to reflect most material information. $^{309}$

Assim, a justificativa de que o insider trading abala a confiança dos investidores no mercado, prejudicando, em última instância, a estabilidade do mercado de capitais como um todo, também não se sustenta, não sendo, portanto, suficiente para sustentar a proibição de tal prática.

\subsubsection{Falhas do argumento quanto à existência de prejuízos para a companhia, seus acionistas e para os investidores}

Como visto, alguns autores entendem que a proibição do insider trading também seria justificada pelo fato de referida prática ter o potencial de (i) atrasar a transmissão das informações dentro da companhia e a divulgação ao público investidor; (ii) interferir nas operações da companhia; e (iii) incentivar os administradores a tomar riscos excessivos; consequências estas que trariam prejuízos à companhia, aos seus acionistas e aos investidores.

Há, no entanto, uma falha básica nesta proposta: tais autores ignoram completamente o fato de que por conta da competição no mercado de trabalho, os insiders típicos - isto é, os administradores -, antes de tentarem obter qualquer vantagem pessoal com seus cargos, buscarão neles permanecer pelo maior tempo possível, até mesmo para maximizar seus lucros futuros. Logo, determinadas ações tomadas pelos administradores que prejudiquem a

\footnotetext{
${ }^{309}$ Ibid. p. 881.
} 
companhia e os investidores podem se mostrar mais custosas no longo prazo do que a vantagem que poderia ser obtida no curto prazo. Neste sentido, confiram-se as lições de CARLTON e FISCHEL:

Markets limit the divergence of interest between managers and shareholders. Competition in product and capital markets limits the ability of managers to pursue actions that do not maximize the value of the firm. The market in corporate control also gives managers an incentive to maximize the value of the firm and simultaneously provides a mechanism for the removal of managers who perform poorly. Finally, given the market for managerial services, value-reducing behavior is constrained by managers' desires to increase the future value of their services to both current and prospective employers. ${ }^{310}$

Neste ponto, BAINBRIDGE ${ }^{311}$ acrescenta que apesar de o atraso na divulgação das informações realmente se mostrar como uma potencial fonte de prejuízo aos investidores, a influência do insider trading neste atraso parece ser demasiadamente exagerada pelos autores pró-proibição. Isto porque, além da escassez de evidências empíricas para demonstrar essa correlação entre atraso na divulgação de informações e insider trading, dado a rapidez com que as transações podem ser feitas no mercado secundário de valores mobiliários, um administrador de posse de informações privilegiadas precisa de não mais do que cinco minutos no telefone com seu corretor para se aproveitar de tais informações.

Ademais, referido autor observa que o insider trading pode criar tanto incentivos para atrasar a divulgação das informações quanto incentivos para divulgar tais informações o mais rapidamente possível, de modo que os administradores possam se aproveitar o quanto antes do impacto gerado na cotação das ações. No entanto, a divulgação prematura de informações pouco tem a ver com a proibição ou não do insider trading, podendo ser facilmente resolvida com base nos deveres de diligência (Art. 153 da Lei $n^{\circ}$ 6.404/76) e

\footnotetext{
${ }^{310}$ CARLTON, Dennis. W. e FISCHEL, Daniel.R. The Regulation of Insider Trading. Stanford Law Review, 1983. p. 869.

311 BAINBRIDGE, Stephen M. Insider Trading: An Overview. p. 14. Disponível em http://ssrn.com/abstract=132529.
} 
de lealdade (Art. 155 da Lei $\mathrm{n}^{\circ}$ 6.404/76) que os administradores possuem para com a companhia e seus acionistas.

Assim, conclui BAINBRIDGE,

[...] a preocupação em assegurar uma divulgação de informações tempestiva não pode justificar uma proibição [ao insider trading] tão ampla como a que existe atualmente. Como visto, tal proibição abrange uma série de pessoas tanto dentro quanto fora da companhia. Em contraste, somente algumas pessoas provavelmente terão o poder de afetar o timing da divulgação. Uma proibição muito mais simples, assim, seria suficiente se esta fosse a preocupação principal para se proibir o insider trading. Com efeito, se esta fosse a principal preocupação, não seria necessário proibir o insider trading de forma alguma. Ao invés disso, poder-se-ia resolver o problema de forma muito mais direta punindo a não divulgação de informações relevantes sem que houvesse uma justificativa estratégica legítima para tanto. ${ }^{312}$ (tradução livre)

Quanto ao argumento de que o insider trading poderia interferir nas operações da companhia, as mesmas considerações feitas acima podem ser aplicadas, isto é, não é preciso proibir o insider trading para impedir que administradores ajam em benefício próprio e em detrimento da companhia. Em verdade, a própria Lei $\mathrm{n}^{\circ}$ 6.404/76 já prevê expressamente esta hipótese, ao vedar em seu Art. 155, I, que o administrador use, “em benefício próprio ou de outrem, com ou sem prejuízo para a companhia, as oportunidades comerciais de que tenha conhecimento em razão do exercício de seu cargo". Não há dúvidas que o enforcement de uma proibição como esta é muito mais simples que a fiscalização das regras de combate ao insider trading.

Por fim, argumenta-se também que a proibição do insider trading se justificaria como uma forma de impedir que os administradores tomem riscos excessivos, pois caso os administradores fossem livres para negociar com base

\footnotetext{
${ }^{312}$ No original: "In any event, concern for ensuring timely disclosure cannot justify a prohibition of the breadth it currently possesses. As we have seen, the prohibition encompasses a host of actors both within and outside the firm. In contrast, only a few actors are likely to have the power to affect the timing of disclosure. A much narrower prohibition thus would suffice if this were the principal rationale for regulating insider trading. Indeed, if this were the main concern, one need not prohibit insider trading at all. Instead, one could strike at the problem much more directly by proscribing failing to disclose material information in the absence of a legitimate corporate reason for doing so." BAINBRIDGE, Stephen M. The Law and Economics of Insider Trading: A Comprehensive Primer. p. 71. Disponível em http://ssrn.com/abstract=261277.
} 
em informações privilegiadas, eles tenderiam a assumir riscos demasiadamente elevados. De acordo com os defensores desta tese, caso o projeto falhasse, somente os acionistas suportariam as perdas, e se o projeto fosse bem sucedido, os administradores conseguiriam maximizar seus ganhos negociando com as ações da companhia antes que a informação fosse divulgada ao público.

Uma primeira abordagem para contra-argumentar este ponto é que o incentivo para escolher projetos de maior risco não é necessariamente ruim. Tendo em vista que os administradores são, em regra, avessos ao risco ${ }^{313}$, eles tendem a escolher projetos mais conservadores, mesmo que o valor da companhia não seja maximizado. ${ }^{314}$ Logo, um mecanismo de incentivo - como o insider trading - que combata essa tendência em escolher investimentos de menor risco pode ser benéfico para os acionistas.

Em segundo lugar, mesmo que os defensores da proibição do insider trading desconsiderem as constatações acima e sustentem que esta prática estimula os administradores a agirem de forma diametralmente oposta aos interesses da companhia e dos acionistas, escolhendo projetos mais arriscados mesmo que estes sejam prejudiciais, a abordagem para rebater este ponto está baseada na primeira observação feita neste item, qual seja a de que os administradores tendem a agir de forma a manter seus cargos e estão em competição constante com outros administradores.

Neste ponto, vale conferir os ensinamentos de CARLTON e FISCHEL:

The reality that managers must work in teams and the various incentives that managers have to maximize the value of their own services suggest that the temptation for managers to engage in value-decreasing activities for the purpose of trading profits may be quite limited.

\footnotetext{
${ }^{313}$ Neste sentido, confira-se SHAVELL, Steven. Risk Sharing and Incentives in the Principal and Agent Relationship. The Bell Journal of Economics. Vol. 10, No. 1, 1979. p. 66.

${ }^{314}$ CARLTON, Dennis. W. e FISCHEL, Daniel.R. The Regulation of Insider Trading. Stanford Law Review, 1983. p. 877.
} 
Assim, o argumento de que o insider trading deveria ser proibido por prejudicar a companhia, seus acionistas e os investidores parece não ser forte o suficiente para justificar a proibição da prática, existindo diversos outros mecanismos para proteger a companhia, seus acionistas e os investidores que, além de serem de aplicação mais simples, geram os mesmos efeitos pretendidos por aqueles que pretendem ver o insider trading proibido.

\subsubsection{Falhas do argumento quanto ao moral hazard e a produção intencional de notícias negativas}

Conforme já referido acima, alguns autores entendem que a proibição do insider trading também se justificaria pelo fato de que a negociação com base em informações privilegiadas tenderia a criar um risco moral para os administradores (insiders) da companhia, que ficariam indiferentes entre negociar com base em informações positivas ou negativas sobre a companhia e, mais ainda, incentivaria os administradores a tomar medidas que impactariam negativamente no valor das ações da companhia. Este argumento é comumente utilizado pela corrente pró-proibição para criticar a ideia do insider trading como um mecanismo de remuneração dos administradores.

O exemplo clássico no qual o insider poderia se beneficiar das informações negativas geradas pela companhia é aquele em que este indivíduo, sabendo antecipadamente sobre determinada notícia que impactará negativamente o preço das ações da companhia, vende tais ações a descoberto pelo preço praticado antes da divulgação, com o objetivo de adquirir estas ações no mercado a um preço mais baixo no futuro - já refletindo a informação negativa - e entrega-las ao comprador, obtendo, assim, o ganho decorrente da diferença entre o preço de venda antes da divulgação e o preço de compra após a divulgação. 
Logo, alguns autores entendem que proibir o insider trading seria uma forma eficiente de evitar que os administradores engajassem a companhia em projetos ruins com a intenção de realizar estas operações de venda a descoberto. Mais uma vez, este argumento não parece ser suficiente para justificar a proibição ao insider trading de forma como ela existe.

Em primeiro lugar, CARLTON e FISCHEL ${ }^{315}$ observam que este problema poderia ser facilmente resolvido se a proibição recaísse apenas sobre as vendas a descoberto pelos insiders, e não sobre todo e qualquer tipo de negociação com base em informações privilegiadas.

Além disso, os autores apontam que mesmo a venda de ações a descoberto por insiders pode funcionar como um incentivo para que administradores avessos a riscos assumam projetos mais arriscados, mas com um maior potencial de retorno. Com efeito, CARLTON e FISCHEL ${ }^{316}$ explicam que algumas oportunidades de investimento, apesar de arriscadas, podem se mostrar extremamente promissoras ex ante, mas, posteriormente, podem se revelar desastrosas, por motivos alheios à vontade ou ao conhecimento dos administradores. Nos casos em que a companhia sofre prejuízos com determinado projeto, a reputação e o "valor de mercado" dos administradores envolvidos também são negativamente afetados.

Assim, permitir que os administradores vendessem ações a descoberto seria uma forma de compensa-los pelo maior risco assumido, que ao mesmo tempo em que pode trazer retornos excepcionais para a companhia - caso o investimento seja bem sucedido -, também pode abalar o valor do capital humano dos administradores - caso o investimento seja mal sucedido.

\footnotetext{
315 Ibid. p. 873

${ }^{316}$ Ibid. p. 872 .
} 
Em segundo lugar, CARTLON e FISCHEL relembram que os administradores geralmente trabalham em equipe e, dessa forma, devem primeiro persuadir uns aos outros que a companhia deve adotar uma estratégia em particular. Confira-se o que dizem os autores:

If a manager uncovers a good opportunity, his efforts will be magnified by the efforts of other managers and employees who themselves will profit by increasing the value of the firm because their own compensation is thereby increased. The same is not true for poor opportunities. Because each manager will be concerned with his own compensation, which will be tied to the performance of the firm, as well as his long run interest in his human capital, he will be unlikely to go along with a strategy that decreases the value of the firm. Thus, the ability of any one manager to pursue bad opportunities will be constrained because other managers and employees will attempt to maximize the firm's value. Collusion to decrease the value of the firm among managers in pursuit of trading profits is unlikely to succeed because, as in all cartels, each rational member will cheat insofar as the gains to a lone cheater from exposing others will exceed his gains from collusion. ${ }^{317}$

Ademais, o problema do risco moral está potencialmente presente em uma série de outras situações onde as regras que proíbem o insider trading não se aplicam, mas que geram efeitos um tanto quanto semelhantes. Considere-se, por exemplo, uma sociedade que fornece materiais essenciais para uma companhia aberta. Visando se beneficiar com a geração de informações negativas sobre a companhia aberta, o diretor da sociedade fornecedora poderia vender as ações desta companhia a descoberto sem grandes riscos de ser punido pela prática de insider trading e, posteriormente, atrasar a entrega dos materiais essenciais para a companhia, prejudicando suas operações e afetando negativamente o preço de suas ações. Caso o lucro com a operação superasse o valor das eventuais indenizações devidas pelo atraso na entrega (inclusive aqueles prejuízos reputacionais sofridos pelo fornecedor), a operação faria sentido em termos econômicos.

No entanto, esta situação não é vista como um problema, possivelmente porque o diretor da sociedade fornecedora e a sociedade fornecedora em si

${ }^{317}$ Ibid. p. 874. 
possuem incentivos em desenvolver e passar ao mercado uma reputação confiável e honesta para fins de captação de novos clientes. O mesmo pode ser dito dos administradores das companhias abertas, que possuem interesses reputacionais análogos que os incentivam a maximizar o valor de seus serviços. ${ }^{318}$

MANNE, por fim, traz ainda outras razões demonstrando porque a proibição do insider trading com o objetivo de impedir produção intencional de notícias negativas não se sustenta diante da lógica econômica do mercado:

Most individual in a position to make Money from inside information will want to maintain that position and improve their future claims on valuable information. Nothing will succeed in that endeavor as much as the continued production of good news. There is no limit to the amount of good news the market can absorb, while bad news carries sharp constraints on its continued production. If too much bad news is created, the firm itself must inevitably fail and all trading cease. And even before that point is reached, other market forces operate to discipline creators of bad news. As the price of a corporation's shares drops relatively low, either an internal shakeup in management or a successful raid by and outsider is more likely to occur. The preference for good news over bad has a very real economic basis. ${ }^{319}$

Assim, uma vez mais, constata-se que, sob o ponto de vista da lógica econômico-jurídica do mercado de capitais, os argumentos a favor da proibição do insider trading não se sustentam diante de uma análise mais cuidadosa das normas que proíbem a prática e das razões econômicas que sustentam a proibição.

\subsubsection{Falhas da misappropriation theory: a premissa básica não se sustenta}

Por fim, cabe analisar as falhas da misappropriation theory. Nas palavras de BAINBRIDGE ${ }^{320}$, "a regulação do insider trading é uma tentativa

\footnotetext{
${ }^{318}$ Ibid. p. 875 .

${ }^{319}$ MANNE, Henry G., Insider Trading and the Stock Market. New York: Free Press, 1966. p. 150.

${ }^{320}$ Tradução livre. No original: "The law of insider trading is society's attempt to allocate the property rights to information produced by a firm". BAINBRIDGE, Stephen M. The Insider Trading Prohibition: A Legal and Economic Enigma. Florida Law Review, Vol. 38, 1986. p. 1. Disponível em SSRN: http://ssrn.com/abstract=303880.
} 
da sociedade de alocar os direitos de propriedade sobre as informações produzidas pela companhia”. É baseada nesta alocação dos direitos de propriedade sobre as informações que surge a misappropriation theory. De acordo com esta teoria, o insider trading deveria ser proibido, pois as informações relevantes geradas dentro da companhia são de sua propriedade. Logo, qualquer pessoa que usa tais informações para negociar em benefício próprio sem o consentimento da companhia estaria se apropriando indevidamente destas informações.

O primeiro problema da misappropriation theory é uma falha de premissa: esta teoria não traz nenhum tipo de razão econômica para se proibir o insider trading. Ela apenas parte da premissa de que as informações relevantes produzidas dentro da companhia a ela pertencem. No entanto, a pergunta que se deve fazer é: porque se decidiu alocar o direito de propriedade sobre as informações para a companhia? E mais: esta alocação faz sentido do ponto de vista da eficiência econômica do mercado? Diante de todo o exposto até aqui, a resposta parece ser negativa.

Como visto, por diversas razões, proibir o insider trading tem o potencial de tornar o mercado menos eficiente - justamente o que as normas de combate ao uso de informações privilegiadas buscam evitar. Assim, banir o insider trading alocando o direito de propriedade sobre as informações para companhia e justificar a proibição com base nesta alocação parece falhar em seu ponto de partida. Em outras palavras: a misappropriation theory só seria uma justificativa plausível para proibir o insider trading se se constatasse de forma robusta que esta prática é maléfica para o mercado, o que conferiria lógica econômica à decisão de conferir à companhia o direito de propriedade sobre as informações por ela geradas. 
Para os defensores da proibição do insider trading, as razões para se conferir à companhia os direitos de propriedade sobre as informações geradas em seu âmbito são as mesmas razões que levam à criação de leis contra a violação de patentes e segredos comerciais: proteger o incentivo econômico em produzir informações socialmente valiosas. ${ }^{321}$ De acordo com esta teoria, a natureza extremamente apropriável (readily appropriable nature) da informação faz com que seja difícil ao desenvolvedor da nova ideia recuperar os custos afundados (sunk costs) incorridos para produzi-la.

Se um inventor, por exemplo, desenvolve uma nova ratoeira, a única maneira de lucrar com sua invenção é vendendo-a no mercado e tornando a nova ideia disponível para seus competidores. Assumindo que o inventor e seu concorrente incorram nos mesmos custos marginais para produzir a ratoeira, $\mathrm{o}$ concorrente conseguirá estabelecer um preço de mercado para as ratoeiras a um valor no qual o inventor será incapaz de recuperar seus custos afundados. Ao antecipar esta possibilidade, o inventor pode não ter incentivos para desenvolver sua nova ideia ex ante. Neste contexto, as leis de proteção às patentes serviriam para proteger o inventor, estimulando-o a produzir novos projetos (ideias e informações) e protegendo-o contra aqueles que tentarem deles se apropriar indevidamente.

Entretanto, o mesmo raciocínio não parece ser aplicável ao insider trading. Conforme relembra BAINBRIDGE ${ }^{322}$, diferentemente de outros ativos, a informação é um tipo de propriedade que pode ser usada por várias pessoas ao mesmo tempo sem se deteriorar. Logo, ao mesmo tempo em que a companhia pode aproveitar as informações para conduzir seus negócios, os administradores podem aproveita-la para, por exemplo, compensar seus esforços na produção desta nova informação.

\footnotetext{
${ }^{321}$ Ibid. p. 18.

322 Ibid. p. 13.
} 
Esta constatação é ainda mais verdadeira em se tratando de insider trading. É o que explica BAINBRIDGE:

A property right in information should be created when necessary to prevent conduct by which someone other than the developer of socially valuable information appropriates its value before the developer can recoup his sunk costs. Insider trading, however, often does not affect an idea's value to the corporation and probably never entirely eliminates its value. Legalizing insider trading thus would have a much smaller impact on the corporation's incentive to develop new information than would, say, legalizing patent infringement. ${ }^{323}$

Neste contexto, CARLTON e FISCHEL sugerem que o famoso Teorema de Coase pode ser útil para determinar a alocação mais eficiente do direito de propriedade sobre as informações geradas pela companhia:

Whether insider trading is beneficial depends on whether the property right in information is more valuable to the firm's managers or to the firm's investors. In either case, the parties can engage in a value-maximizing exchange by allocating the property right in information to its highest-valuing user. If the critics of insider trading are correct, therefore, both the firm's investors and the firm's insiders could profit by banning insider trading, thereby allocating the property right in information to the firm's investors.

It is important to recognize that this mutual incentive to allocate the property right in information to its highest-valuing user does not depend on actual negotiations between insiders and investors. As long as investors understand the possibility of insider trading, both share price and managers' compensation will be higher if the efficient allocation is reached than if it is not. ${ }^{324}$

Desta forma, tendo em vista os potenciais benefícios que a legalização do insider trading traria para as companhias abertas, seus acionistas, os investidores em geral e o desenvolvimento do mercado de capitais como um todo, justificar a proibição do insider trading com base na misappropriation theory simplesmente não se sustenta, falhando em sua premissa básica.

323 BAINBRIDGE, Stephen M. Insider Trading: An Overview. p. 19. Disponível em http://ssrn.com/abstract $=132529$.

${ }^{324}$ CARLTON, Dennis. W. e FISCHEL, Daniel.R. The Regulation of Insider Trading. Stanford Law Review, 1983. p. 863. 


\subsubsection{A ineficiência econômica da criminalização do insider trading: uma proposta para a descriminalização}

Sanções criminais trazem, em geral, consequências muito mais graves que as sanções civis, não só pela possibilidade de condenação a pena privativa de liberdade, como pelo estigma social causado por uma condenação desta natureza. No caso do insider trading, esta realidade não é diferente.

Ainda que as sanções administrativas impostas pela CVM possam somar - como já somaram em alguns casos - milhões de reais, o Art. 27-D da Lei $n^{\circ} 6.385 / 76$ prevê que a utilização de informação privilegiada é punível com pena de reclusão de 1 (um) a 5 (cinco) anos, e multa de até 3 (três) vezes o montante da vantagem ilícita obtida em decorrência do crime.

Por outro lado, o ônus da prova exigido para que haja uma condenação pela prática de insider trading é igualmente maior na esfera criminal, se comparada às esferas administrativas e civis. Como já referido acima, no âmbito administrativo, a CVM costuma lançar mão de uma série de indícios e presunções de forma a facilitar a investigação e condenação dos acusados pelo uso de informações privilegiadas. Além disso, nos casos investigados pela autarquia, tanto os insiders primários quanto os insiders secundários podem e são punidos, ainda que algumas presunções e indícios aplicáveis ao primeiro grupo não possam ser igualmente consideradas para o segundo.

Já no âmbito penal, os requisitos para uma condenação pela prática de insider trading são muito mais rígidos, uma vez que, conforme já mencionado anteriormente, por força da atual redação do Art. 27-D da Lei ${ }^{\circ}$ 6.385/76, somente aquelas pessoas que por lei tem o dever de manter sigilo é que podem ser criminalmente processadas e punidas pela negociação com base em informações privilegiadas. Ademais, além da discussão já existente na doutrina quanto à necessidade ou não da efetiva obtenção da vantagem para a 
configuração do ilícito penal, o já referido Projeto de Lei do Senado $\mathrm{n}^{\circ}$ 236/2012 propõe alterar o Art. 27-D para efetivamente tornar o insider trading um crime material.

Esta tendência em endurecer os requisitos para se obter uma condenação criminal pela prática de insider trading também é sentida em outros países, conforme observado por FRIJNS et. al.:

This view was clearly articulated in a speech by members of the US Securities Exchange Commission in 1998, where they argued that due to the largely inferential nature of the crime, where a case is often based around circumstantial evidence relating to meetings, phone calls and opportunity, it will be difficult to establish guilt to the standard of beyond a reasonable doubt. This view was also recently stressed by the Chairman of the Australian Securities and Investment Commission who noted that despite recent successful criminal prosecutions, the burden of proof and the evidence required remained problematic. ${ }^{325}$

Neste contexto, DUFFY analisa o pesado ônus da prova normalmente existente nos casos de insider trading, assim concluindo:

Regulators will often find themselves in a position where they can identify a person with inside information on a particular security, a person who traded in that security, a relationship between the two persons and even evidence of communications between them (such as telephone records). This however may still not be enough unless there is some evidence of the content of the communications and, in particular, the conveying of price sensitive information that was not generally available. Further, though a circumstantial case for communication may exist, it is usually necessary to establish what was said to identify it as price sensitive information. Also, given the seriousness of such an allegation it is unlikely that evidence of such communication can be inferred from the surrounding circumstances. ${ }^{326}$

Assim, esta grande dificuldade de se obter uma condenação pela prática de insider trading na esfera criminal acaba gerando um efeito ambíguo no combate à negociação com base em informações privilegiadas. Este efeito existe não só quando sanções criminais substituem sanções civis, mas também quando sanções civis e criminais coexistem.

\footnotetext{
325 FRIJNS, Bart; GILBERT, Aaron B; e TOURANI-RAD, Alireza. Do Criminal Sanctions Deter Insider Trading? (March 14, 2011). p. 3. Disponível em SSRN: http://ssrn.com/abstract=1785873.

${ }^{326}$ DUFFY, M. Insider Trading: Addressing the continuing problems of proof. Australian Journal of Corporate Law, 23, 2009. p. 155.
} 
Conforme observado por BHATTACHARYA e DAOUK ${ }^{327}$, se uma lei de combate ao insider trading impondo apenas sanções civis é promulgada, mas não é aplicada (enforced), ela impedirá apenas que algumas pessoas negociem de forma ilegal. No entanto, BRIS ${ }^{328}$ adverte que aqueles que não forem impedidos passarão a negociar desta forma com maior intensidade. A inclusão de sanções penais neste contexto, por sua vez, pode impedir alguns insiders que antes não eram impedidos pelas sanções civis, mas aqueles que não se sentirem coagidos pelas sanções mais severas também passarão a negociar com mais intensidade.

Para testar empiricamente estas afirmações, FRIJNS et. al. ${ }^{329}$ promoveram um estudo no âmbito do mercado de capitais neozelandês, um dos últimos países com um mercado relativamente desenvolvido a impor sanções criminais à prática do insider trading, por meio do Securities Market Amendment Act 2006 (SMAA). Utilizando-se de modelos matemáticos e dados econômicos das companhias mais líquidas listadas na New Zealand Stock Exchange (NZX), os autores analisaram o impacto econômico que as sanções penais contra o insider trading geraram na eficiência do mercado de capitais da Nova Zelândia.

O estudo conclui que, de uma maneira geral, a introdução de sanções penais contra o insider trading na Nova Zelândia aumentou significativamente os custos de transação e a proporção de assimetria informacional, principalmente pelo fato de uma condenação criminal com base na lei recémpromulgada ser extremamente difícil. Assim, confirmando a hipótese acima apresentada, a dificuldade em aplicar as leis contra o insider trading acabaram por diminuir seu efeito coibidor (deterrence effect), fazendo com que

\footnotetext{
${ }^{327}$ BHATTACHARYA, Uptal e DAOUK, Hazem. When no law is better than a good law. (April 27, 2009). AFA 2008 New Orleans Meetings Paper. p. 6. Disponível em http://ssrn.com/abstract=558021

${ }^{328}$ BRIS, A. Do Insider Trading Laws Work? European Financial Management, 11, 2005. p. 289.

${ }^{329}$ FRIJNS, Bart; GILBERT, Aaron B.; e TOURANI-RAD, Alireza. Do Criminal Sanctions Deter Insider Trading? (March 14, 2011). Disponível em SSRN: http://ssrn.com/abstract=1785873.
} 
determinadas pessoas passassem a negociar ilegalmente de forma ainda mais intensa.

Assim, este estudo sugere que a criminalização do insider trading, assim como sua proibição de uma maneira geral, produz o efeito inverso daquele pretendido, piorando - e não melhorando - a eficiência do mercado de capitais.

\subsubsection{Uma posição intermediária: a legalização do insider trading no sell side}

Como visto até aqui, o debate envolvendo a legalização ou proibição do insider trading costuma se dar, geralmente, em bases absolutas, isto é, ou se proíbe ou se legaliza por completo todo e qualquer tipo de insider trading. É o que observa LAMBERT:

One of the most striking aspects of the well-worn insider trading debate is its starkness. Assuming that insider trading must be treated as a whole, ban defenders and opponents have argued over liberalization in all-or-nothing terms; they have not considered whether some species of insider trading should be treated differently than others. ${ }^{330}$

Referido autor, porém, propõe uma solução intermediária: permitir a negociação com base em informações privilegiadas somente nos casos de "price-decreasing insider trading", isto é, em operações que tragam o valor da ação para baixo (vendas em geral, vendas a descoberto e compra de opções de venda realizadas com base em informações negativas sobre determinada companhia). Já nas operações chamadas de "price-increasing insider trading" (compra de ações e de opções de compra com base em informações positivas sobre determinada companhia), onde o preço das ações é influenciado para

\footnotetext{
${ }^{330}$ LAMBERT, Thomas A.. A Middle Ground Position in the Insider Trading Debate: Deregulate the Sell Side (October 1, 2007). University of Missouri-Columbia School of Law. Legal Studies Research Paper No. 2007-18. p. 5. Disponível em http://ssrn.com/abstract=1018758.
} 
cima, a utilização de informações relevantes para negociar no mercado continuaria sendo proibida.

De acordo com LAMBERT, este tratamento desigual se justificaria, pois o "price-decreasing insider trading provides significantly more value to investors than price-increasing insider trading". E continua:

Most notably, price-decreasing insider trading provides an effective means of combating the problem of overvalued equity - i.e., a stock price that is so high that it cannot be justified by expected future earnings.

$[\ldots]$

Deregulation of price-decreasing insider trading would create a means by which corporate insiders - those in the best position to know when a stock is overvalued could signal the market that the stock price is too high, thereby reducing the costs associated with overvalued equity. While deregulation of price-increasing insider trading could similarly remedy undervalued equity, undervaluation causes fewer problems than overvaluation, and there are numerous other mechanisms for addressing that sort of mispricing. ${ }^{331}$

Sem a pretensão de destrinchar no presente trabalho todos os argumentos trazidos pelo mencionado autor, julga-se interessante abordar, ainda que resumidamente, os principais pontos da tese por ele sugerida.

Em primeiro lugar, LAMBERT busca explicar porque a superavaliação de ações é mais provável de acontecer e persistir do que a subavaliação. Baseado em dados empíricos ${ }^{332}$, o autor afirma que esta constatação não deveria causar grandes surpresas, já que os dois principais grupos de pessoas responsáveis por disponibilizar as informações que corrigiriam o preço de ações mal precificadas - administradores e analistas de investimento - não só tendem, como tem melhores ferramentas para corrigir o preço de ações que estão subavaliadas.

\footnotetext{
331 Ibid. p. 1.

332 A referência trazida pelo autor é a obra de Mark T. Finn, Russell J. Fuller e John L. Kling, intitulada "Equity Mispricing: It's Mostly on the Short Side", publicada no Financial Analysts Journal, Vol. 55, No. 6, Behavioral Finance (Nov. - Dec., 1999).
} 
No que se refere aos administradores, algumas razões os levariam a não corrigir o preço das ações superavaliadas de emissão da companhia que administram. LAMBERT explica que quando os administradores de uma companhia estão diante de um fato relevante ainda não divulgado que impactará negativamente a cotação das ações na bolsa, dois problemas principais surgiriam: o chamado "last period problem" e o "multiple audience problem". Confira-se a explicação do autor:

The last period problem exists when the undisclosed news is so bad that it might cause insolvency or some kind of managerial shake-up. If senior managers think the undisclosed bad news will result in company insolvency or in their being fired or demoted, they may rationally decide that the costs to them of misleading disclosures (or omissions) are less than the costs to them of candor. The multiple audience problem results from the fact that corporate managers cannot make targeted disclosures of negative information only to shareholders. When managers make a corporate disclosure, they inform not only shareholders, but also such corporate constituencies as consumers, employees, and suppliers. They may wish to conceal price-decreasing information in order to protect relationships with those constituencies. It may be quite rational, then, for corporate managers to conceal price-decreasing information, despite their interest in maintaining a reputation for candor. $^{333}$

Além disso, LAMBERT aponta, baseado em estudos promovidos no campo da psicologia ${ }^{334}$, que as pessoas, em geral, tendem a superestimar suas próprias habilidades e conquistas. Neste sentido, os administradores tenderiam a dar maior ênfase a fatos positivos e menor ênfase a fatos negativos ${ }^{335}$. Com

\footnotetext{
${ }^{333}$ LAMBERT, Thomas A.. A Middle Ground Position in the Insider Trading Debate: Deregulate the Sell Side (October 1, 2007). University of Missouri-Columbia School of Law. Legal Studies Research Paper No. 2007-18. p. 6. Disponível em http://ssrn.com/abstract=1018758.

${ }^{334} \mathrm{O}$ autor cita os seguintes trabalhos: (i) KIESLER, Sara e SPROULL, Lee. Managerial Responses to Changing Environments: Perspectives on Problem Sensing from Social Cognition, 27 ADMIN. SCI. Q. 548, 549 (1982); (ii) LORD, Charles G. et al., Biased Assimilation and Attitude Polarization: The Effects of Prior Theories on Subsequently Considered Evidence, 37 J. PERSONALITY \& SOC. PSYCHOL. 2098, 2099 (1979); e (iii) BAZERMAN, Max H. Judgment in managerial decision making. (3d ed. 1994).

${ }^{335}$ Este problema também está ligado à forma como a informação chega até o alto escalão da administração de uma companhia. Confira-se, neste sentido, a explicação de Lambert: "Perhaps more significant than these cognitive biases are the dynamics of information flow within the corporation. Much of the information concerning the success of a firm's endeavors - particularly non-quantifiable, "soft" information, such as the degree of consumer enthusiasm for new products, the progress of products through the research and development pipeline, etc. - is not immediately available to the firm's senior managers. Instead, the agents with the most direct access to this information tend to be non-managerial employees and low to mid-level managers. Senior managers, then, must rely on their
} 
isso, ao divulgar uma notícia capaz de impactar positivamente no preço da ação, o administrador o faria de uma forma mais exagerada, o que, consequentemente, elevaria a cotação da ação para um preço acima do real valor daquela informação. Por outro lado, diante de uma notícia ruim, com potencial de impactar negativamente o preço da ação, o administrador poderia optar, conforme visto acima, por não divulgar a informação, ou por divulga-la de forma incompleta, não transmitindo ao mercado o real significado daquela notícia e, consequentemente, deixando de refletir no preço da ação o verdadeiro valor daquela informação. Em ambos os cenários - fato relevante positivo e negativo - a ação tenderia a ser superavaliada.

Não só os administradores apresentariam uma tendência a corrigir o preço das ações para cima, mas a não corrigir para baixo, como questões de ordem prática justificariam esta dinâmica. É o que explica LAMBERT:

Consider a manager confronted with evidence that her company is undervalued. She might issue a press release explaining why the market was undervaluing her firm, or she could initiate a stock repurchase, thereby signaling management's strong belief that the stock is undervalued. Managers finding undervalued equity to be a chronic problem could adopt equity based compensation schemes for executives (e.g., payment in stock or stock options). A manager confronting overvalued equity, by contrast, is somewhat strapped. As a practical matter, managerial candor is not an option, for a manager who directly announced to the market that his corporation's stock was overpriced probably would not keep his job for very long. Nor could the manager correct the mispricing by engaging in a sale transaction that would send the reverse signal of a stock repurchase. Whereas the signal sent by a stock buy-back is relatively unambiguous, a sale transaction designed to signal overvaluation (e.g., an

underlings to provide them with information regarding crucial aspects of the firm's prospects. [...] The problem with this hierarchical system is that there is a danger at each stage of the information-relay system that material information will be suppressed or exaggerated in some fashion, as each information-provider will be tempted to tweak his message to conform to his self-interest. Seeking promotion or other rewards, he has an incentive to inform his superiors of every bit of value-enhancing information of which he is aware. By contrast, if he knows his endeavors are not going as well as expected, he may positively spin that information or keep it to himself in the hope that things will turn around soon. By the time the price-affecting information reaches the senior managers in charge of corporate disclosure, it is likely to have been "massaged" so as to make underlings look good. In other words, it is likely to be positively biased. Unaware of negative information, the senior managers in charge of corporate disclosures can neither directly disclose the bad news nor factor it into their more general forecasts." LAMBERT, Thomas A. A Middle Ground Position in the Insider Trading Debate: Deregulate the Sell Side (October 1, 2007). University of Missouri-Columbia School of Law. Legal Studies Research Paper No. 2007-18. p.7. Disponível em http://ssrn.com/abstract=1018758. 
equity offering or a sale of treasury shares the corporation previously purchased) is much noisier. It could easily be interpreted as a means of raising capital for some sort of corporate undertaking. And, of course, equity-based compensation, which helps prevent undervaluation, exacerbates overvaluation by inducing managers to drive the share price higher even when they know the company is overvalued. There is thus an asymmetry in the degree to which managers and market forces are able to correct the different species of mispricing: the primary options available for correcting negative mispricing are not practically available when the mispricing is in the positive direction. $^{336}$

Em relação aos analistas de investimento - que, como visto, também desempenhariam um papel importante na correção do preço das ações -, a principal razão que os levariam a contribuir para a correta precificação de ações subavaliadas, mas a não fazer o mesmo para ações superavaliadas, residiria no fato de que a maioria destes profissionais é, segundo LAMBERT, empregada pelas mesmas instituições que prestam serviços financeiros - tais como estruturação e intermediação de ofertas públicas, underwriting - para companhias abertas.

Assim, ao contratar uma instituição integrante do sistema de distribuição para, por exemplo, estruturar e intermediar uma oferta pública inicial de ações, as companhias tenderiam a buscar empresas que possuíssem analistas "otimistas", ou seja, que recomendariam a compra do papel não só quando da oferta pública, mas também posteriormente, contribuindo para a valorização da ação no mercado e para uma boa imagem da companhia.

Para ilustrar sua explicação, LAMBERT traz o seguinte exemplo prático envolvendo as ações da Enron pouco antes do escândalo que culminou com sua quebra:

In the autumn of 2001, just weeks before Enron's December 2, 2001 bankruptcy, each of the fifteen largest Wall Street firms covering Enron's stock had buy recommendations in place. And as late as October 26, 2001 - after Enron's CFO had been forced to resign, the SEC had initiated an Enron investigation, and the Wall

\footnotetext{
${ }^{336}$ LAMBERT, Thomas A.. A Middle Ground Position in the Insider Trading Debate: Deregulate the Sell Side (October 1, 2007). University of Missouri-Columbia School of Law. Legal Studies Research Paper No. 2007-18. p.8. Disponível em http://ssrn.com/abstract=1018758.
} 
Street Journal had run several stories about Enron's earnings management problems ten of the fifteen largest Wall Street firms covering Enron maintained buy recommendations, as did fifteen of seventeen top Wall Street analysts surveyed by Thompson Financial/First Call. Sadly, Enron was no outlier. The ratio of buy to sell recommendations has recently been as high as 100-to-1, and in the period immediately preceding a $60 \%$ drop in the NASDAQ, only $0.8 \%$ of analysts' recommendations were sell or strong sell. Thus, the evidence suggests that analysts, quick to report undervaluation by issuing buy recommendations, are less responsive to mispricing in the positive direction.

Tendo demonstrado as razões para a superavaliação de ações ser mais comum que a subavaliação, Lambert passa, então, a explicar porque ações superavaliadas tendem a causar mais prejuízos aos investidores e ao mercado em geral do que ações subavaliadas. Para o autor, a explicação para esta tendência estaria intimamente ligada aos chamados custos de agência (agency costs). Neste ponto, confira-se a explicação de Lambert:

Agency costs are the costs that arise from individuals' cooperative efforts. They appear whenever any principal hires an agent to act on his behalf, for the agent will always have an incentive to act opportunistically or to shirk, and the principal must therefore take steps to prevent or insure against such behavior. Agency costs may thus be defined as the sum of the contracting, monitoring, and bonding costs incurred to reduce the conflicts of interest between principals and agents, plus the residual loss that occurs because it is generally impossible to perfectly identify the interests of agents and their principals (Jensen \& Meckling 1976). In a corporation, agency costs arise because the directors, officers, and other managers charged with running the corporation's business have interests that conflict with those of the corporation's residual claimants, the shareholders. ${ }^{337}$

Ainda que o mercado de capitais represente uma poderosa ferramenta para minimizar os custos de agência - já que as companhias que possuem mecanismos efetivos para diminuir tais custos tendem a ser mais atraentes para os investidores -, LAMBERT aponta que estudos econômicos sugerem que, quando as ações estão superavaliadas, os custos de agência no mercado de capitais costumam ser potencializados.

Antes, porém, de explicar por que ações superavaliadas aumentam os custos de agência, cabe verificar porque ações subavaliadas não afetam de

\footnotetext{
${ }^{337}$ Ibid. p. 10.
} 
forma relevante tais custos. A explicação para isso é simples: quando as ações de uma companhia estão subavaliadas, os incentivos dos acionistas e dos administradores tendem a estar alinhados, uma vez que ambos os grupos buscarão elevar o preço da ação até o seu real valor.

Os acionistas buscarão esta correção de preço, pois um aumento no valor de suas ações melhora sua situação financeira pessoal no longo prazo, assim como contribui positivamente para a situação financeira da própria companhia, diminuindo, por exemplo, o custo de capital para levantar novos recursos. Já os administradores desejarão este resultado, uma vez que ações valorizadas tendem a contribuir para seu prestígio profissional e sua remuneração, conferindo, ainda mais flexibilidade à companhia, ao diminuir o custo de capital, como já referido acima. Assim, conclui LAMBERT, "given the overlap in shareholders' and managers' desires, it is unlikely that undervaluation will occasion any managerial behavior that diverges from shareholder interests". 338

No caso de ações superavaliadas, porém, o cenário muda completamente de figura, uma vez que os interesses dos acionistas e dos administradores passam a ser diametralmente opostos ${ }^{339}$. Isto porque, por mais que os administradores não desejem que o preço das ações caia e se ajuste ao seu real valor, eles sabem que não conseguirão manter a alta cotação (artificial)

\footnotetext{
338 Ibid. p. 11.

${ }^{339}$ Em um primeiro momento, poder-se-ia imaginar que aos acionistas também interessaria manter a superavaliação das ações, pois, em última análise, quanto mais alta a cotação das ações, melhor sua situação financeira. No entanto, como a superavaliação tende a ser eventualmente corrigida, investidores de médio e longo prazo dificilmente conseguirão capturar os benefícios transitórios da superavaliação. No que diz respeito aos investidores de curto prazo, por mais que este grupo tenha mais chances de se beneficiar dos períodos de superavaliação, isso só será possível se eles conseguirem vender suas ações antes da inevitável correção de preços. Esta estratégia, conhecida como "bail before correction" traz riscos muito maiores para os acionistas do que para os administradores, uma vez que os primeiros sabem muito pouco sobre fatos ocorridos na companhia que podem revelar a superavaliação e tendem, portanto, a demorar demais para vender suas ações. LAMBERT, Thomas A.. A Middle Ground Position in the Insider Trading Debate: Deregulate the Sell Side (October 1, 2007). University of Missouri-Columbia School of Law. Legal Studies Research Paper No. 2007-18. p.12. Disponível em http://ssrn.com/abstract=1018758.
} 
das ações indefinidamente e que, eventualmente, a correção do preço irá ocorrer, o que os levará a se abster de tomar medidas para corrigir o preço das ações, ou, ainda pior, a agir de forma a manter o preço das ações elevado, tomando o que Lambert chama de "value-destroying actions". Confira-se a explicação do autor:

In order to protect their jobs and reputations, managers of overvalued firms often need to "buy time"-i.e., to trick the market into maintaining the high stock price until they can exit the firm (both as shareholders and as managers) or can produce the corporate performance required to justify the stock price. Such continued trickery requires beating analysts' expectations, for the capital markets routinely punish firms that fail to meet such expectations. The problem is that managers of overvalued firms cannot perpetually meet analysts' expectations by exploiting legitimate valuecreating opportunities. Once those options have been exhausted, they will eventually turn to gimmicks that are designed to produce numbers that appease the market but actually reduce long-term firm value. ${ }^{340 / 341}$

JENSEN identifica três destas medidas normalmente adotadas por administradores de companhias superavaliadas: (i) visando passar a aparência ao mercado de que a companhia está cumprindo suas expectativas de crescimento, os administradores usam as ações superavaliadas como lastro para realizar aquisições com alto valor destrutivo no longo prazo (value destroying acquisitions); (ii) os administradores se aproveitam do acesso fácil da companhia a instrumentos de dívida e equity para realizar gastos internos excessivos e arriscados investimentos de valor presente negativo, passando a falsa impressão ao mercado que de que tais investimentos agregam valor; e (iii) eventualmente, os administradores passarão a se envolver em

\footnotetext{
${ }^{340}$ Ibid. p. 13.

${ }^{341}$ Confira-se, neste sentido, o exemplo trazido por McLean e Elkind referente o colapso financeiro da giante Enron: "Enron's accounting games were never meant to last forever [...]. The goal was to maintain the impression that Enron was humming until [CEO Jeff] Skilling's next big idea kicked in and started raking in real profits [...]. In Skilling's mind, though, there was no way he was going to fail. He had always succeeded before, and his successes had transformed the company. Why would it be any different with EES and broadband?" MCLEAN, Bethany e ELKIND, Peter. The Smartest Guys in the Room: The Amazing Rise and Scandalous Fall of Enron. Penguin Group, 2003. p. 171.
} 
manipulações contábeis e práticas fraudulentas para manter a aparência de crescimento $^{342}$.

A liberação do price-decreasing insider trading poderia, por exemplo, impedir ou ao menos coibir a prática de fraudes contábeis ${ }^{343}$. Para ilustrar esta afirmação, considere-se a seguinte situação: o diretor financeiro de uma companhia aberta, ao perceber que a alta cotação das ações não reflete a atual situação financeira da companhia, e vendo a data final para divulgação das demonstrações financeiras se aproximar, começa a tomar medidas para manipular os números e "maquiar" os balanços, de forma a justificar o preço das ações em bolsa e impedir sua queda. Caso o price-decreasing insider trading fosse permitido, os demais administradores, a par desta situação, poderiam passar a vender suas ações em bolsa (ou realizar vendas a descoberto ou comprar opções de venda), de forma a pressionar o preço das ações para o seu real valor. Assim, quando as demonstrações financeiras fossem finalmente divulgadas, ainda que a cotação das ações não refletisse fielmente a situação financeira da companhia, seu preço estaria, em tese, mais próximo deste patamar.

Assim, conclui LAMBERT, considerando que a supervalorização das ações tende a ser mais comum que a subvalorização e a impor maiores custos aos investidores quando ocorre, o insider trading que pressiona o preço de ações supervalorizadas para o seu real valor traz mais benefícios aos investidores do que o insider trading que influencia o preço de ações subvalorizadas para cima. ${ }^{344}$ Logo, a legalização do chamado price decreasing

\footnotetext{
342 JENSEN, Michael C. Agency Costs of Overvalued Equity. 34 FIN.MGMT. 5, 2005. p. 10.

${ }^{343}$ Para uma análise de como o insider trading poderia ser usado como uma ferramenta para evitar fraudes contábeis, veja-se WAGNER, Robert E. Gordon Gekko to the rescue?: insider trading as a tool to combat accounting fraud. University of Cincinnati Law Review: Vol. 79: Iss. 3, Article 2, 2011. Disponível em http://scholarship.law.uc.edu/uclr/vol79/iss3/2.

${ }^{344}$ LAMBERT, Thomas A.. A Middle Ground Position in the Insider Trading Debate: Deregulate the Sell Side (October 1, 2007). University of Missouri-Columbia School of Law. Legal Studies Research Paper No. 2007-18. p.16. Disponível em http://ssrn.com/abstract=1018758.
} 
insider trading conferiria mais eficiência ao funcionamento do mercado de capitais.

Em linhas gerais, a tese sugerida por Thomas A. Lambert apenas reforça tudo o que já foi exposto até então, demonstrando que o insider trading pode ser um mecanismo extremamente eficaz na contribuição para um mercado de capitais mais eficiente, combatendo problemas como a superavaliação de ações e as fraudes contábeis.

Entretanto, tendo em vista as já mencionadas dificuldades práticas e jurídicas de se processar e condenar aqueles que se utilizam de informações privilegiadas, somadas ao baixo índice de condenação e, ainda, às pesadas penas que podem ser aplicadas aos condenados pela referida prática, manter a proibição do "price-increasing insider trading" vai no sentido oposto daquilo que os autores da escola do law and economics e defensores do insider trading propõem.

Apesar de os mecanismos para corrigir o preço das ações para cima serem mais eficientes e os custos envolvidos nessa correção serem menores do que aqueles envolvidos para corrigir o preço das ações para baixo, o custo da proibição do "price increasing insider trading" e as sanções que a acompanham parecem, por tudo que já foi até aqui exposto, superar os seus benefícios.

Como visto, não só o insider trading, de uma maneira geral, e o "price increasing insider trading", especificamente, possuem uma valiosa carga informativa para o mercado, refletindo no preço das ações informações que por uma série de motivos ainda não estão publicamente disponíveis, como estas formas de negociação representam um eficiente mecanismo de remuneração dos administradores - notadamente o "price increasing insider trading" -, possuindo uma série de vantagens se comparadas às outras formas de 
remuneração. Ademais, as graves falhas das teorias que justificariam a proibição do insider trading fragilizam demasiadamente as proibições legais da forma como existem hoje.

Assim, não obstante os méritos da tese de Thomas A. Lambert, e a menos que se demonstre com dados empíricos sólidos e argumentos consistentes que a negociação com base em informações privilegiadas é prejudicial para o mercado de capitais, a discussão sobre a proibição ou legalização do insider trading parece se reduzir, de fato, a termos absolutos.

\subsubsection{Uma proposta concreta de regulação: a proibição do insider trading a cargo das companhias}

Conforme visto no Capítulo 4 deste trabalho, as normas que proíbem a negociação com base em informações privilegiadas no Brasil advêm, basicamente, das Leis n ${ }^{\circ}$ 6.404/76 e 6.385/76 e da Instrução CVM N 358/02. Pela redação dos dispositivos que vedam o insider trading nestes diplomas, não seria possível que as companhias excetuassem seu cumprimento por meio de seu estatuto social, por exemplo. Isto é, as normas de combate ao insider trading no Brasil, assim como na maioria dos países do mundo, têm caráter cogente, não admitindo que as partes disponham em sentido contrário.

No entanto, alguns autores trazem argumentos sustentando que, tendo em vista as diversas dúvidas que se colocam sobre a real necessidade e eficiência das normas que proíbem o insider trading, melhor seria que tais normas delegassem às companhias abertas o poder para proibir ou não tal prática.

De acordo com MANNE, antes de os Estados Unidos adotarem suas primeiras normas de combate ao insider trading, existiam, de fato, algumas companhias que já proibiam que seus administradores, diretores e funcionários 
se utilizassem de informações relevantes ainda não divulgadas sobre a companhia. No entanto, o mesmo autor observa que antes do Securities Exchange Act de 1934 e da regulação que o seguiu, a grande maioria das companhias abertas dos Estados Unidos não trazia qualquer vedação ao insider trading em seus estatutos. Para MANNE, esta falta de interesse das companhias em proibir a utilização de informações privilegiadas não poderia ser mero acaso. Assim, indaga o autor: se o insider trading é realmente tão nefasto para a companhia, para os acionistas e para o mercado como um todo, porque a falta de interesse das companhias em coibir tal prática? ${ }^{345}$

CARLTON e FISCHEL corroboram este argumento sustentando que até a década de 1980 - quando a proibição ao insider trading já estava em vigor nos Estados Unidos - pouquíssimas eram as companhias que efetivamente possuíam em seus estatutos sociais disposições proibindo expressamente a prática, e mesmo as que possuíam, provavelmente o faziam apenas como uma resposta automática à regulação.

Para os autores, tendo em vista que o insider trading sempre foi prática comum no mercado, independentemente da proibição, as companhias ainda teriam incentivo para impedir a utilização de informações privilegiadas por meio de normas internas, caso a proibição fosse de fato do melhor interesse dos investidores. No entanto, a ausência de medidas restritivas adotadas pelas companhias além daquilo exigido pela regulação sugere que, ao contrário do que se tem como verdade absoluta, o insider trading não causa nenhum dano à companhia, aos acionistas e aos investidores. ${ }^{346}$

Ainda segundo CARLTON e FISCHEL, a desnecessidade de proibição do insider trading por meio de normas cogentes se justificaria, pois tendo em

\footnotetext{
${ }^{345}$ MANNE, Henry G. Insider trading and property rights in new information. Cato Journal, Vol. 4, No. 3, 1985. p. 940.

${ }^{346}$ CARLTON, Dennis. W. e FISCHEL, Daniel.R. The Regulation of Insider Trading. Stanford Law Review, 1983. pp. 858-859.
} 
vista a natureza extremamente competitiva do mercado de capitais, as companhias teriam um forte incentivo em proibir tal prática caso a mesma se mostrasse realmente prejudicial aos investidores. Em outras palavras: se o insider trading fosse de fato ruim, as companhias que permitissem a utilização de informações privilegiadas encontrar-se-iam em desvantagem competitiva face às companhias que impedem referida prática. ${ }^{347}$

Assim, a proibição do insider trading só se justificaria se estivesse claro que as partes - companhia, acionistas e administradores - tentaram impedir a prática privadamente por meio de um contrato, mas que a intervenção estatal por meio das normas apresentou uma vantagem comparativa em promover o enforcement destes contratos. Neste ponto, DOOLEY ${ }^{348}$ aponta que as companhias possuem uma clara vantagem comparativa sobre o Estado em termos de efetividade e custos na aplicação das regras, motivo pelo qual a proibição do insider trading deveria ser matéria a ser negociada privadamente entre as partes e somente fiscalizada pelo Estado caso a obrigação previamente contratada fosse descumprida.

De todo modo, CARLTON e FISCHEL ${ }^{349}$ explicam que esta vantagem comparativa é irrelevante sem que se possa demonstrar que as companhias efetivamente tentaram limitar o insider trading pela via contratual. Sem esta evidência, nunca será possível saber se a regulação é de fato o meio mais eficiente, ou se ela está apenas limitando uma forma muito mais simples e barata de se regular a utilização de informações privilegiadas.

\footnotetext{
${ }^{347}$ Ibid. p. 862.

${ }^{348}$ DOOLEY, Michael P. Enforcement of Insider Trading Restrictions. Virginia Law Review. Vol. 66, No. 1 (Fev., 1980). p. 46.

${ }^{349}$ CARLTON, Dennis. W. e FISCHEL, Daniel.R. The Regulation of Insider Trading. Stanford Law Review, 1983. pp. 858-859.
} 


\section{CONCLUSÃO}

Quando Henry G. Manne publicou sua obra "Insider Trading and the Stock Market" em 1966, seu trabalho deu início a uma verdadeira revolução na forma como o insider trading passou a ser estudado. Usando ferramentas econômicas para analisar um problema até então discutido somente no campo jurídico, a pioneira obra de Manne deu novo fôlego ao debate do insider trading, abrindo caminho para uma análise da questão sob um ponto de vista nunca antes pensado.

A prática da negociação com base em informações privilegiadas passou a ser percebida com mais intensidade após o surgimento do fenômeno conhecido como "separação entre propriedade e gestão". Na medida em que aqueles que participavam do processo decisório diário das companhias passaram a ser não mais o acionista controlador, mas administradores profissionais com pouca ou nenhuma participação no capital, questões como os custos de agência e o insider trading passaram a ser estudados com maior profundidade.

No entanto, foi somente após a crise norte-americana de 1929 e a posterior regulação do mercado de capitais daquele país de forma mais ampla e detalhada, com o Securities Act de 1933 e o Securities and Exchange Act de 1934, que o insider trading passou a ser encarado como um problema. Esta percepção pode ser explicada pelo sentimento que se buscou criar à época, de que os ideais liberais que pautavam a regulação norte-americana haviam falhado, sendo necessário que o Estado se tornasse mais presente como regulador da economia e do mercado como um todo.

No entanto, muitas das legislações e medidas tomadas no período póscrise foram não só consideradas inconstitucionais pela Suprema Corte dos Estados Unidos, como trouxeram consequências desastrosas para a economia 
americana, gerando o efeito oposto daquilo que pretendiam e prolongando uma crise que poderia ter sido resolvida mais rapidamente.

Neste contexto, a proibição do insider trading se apresentava como uma excelente ferramenta a ser utilizada pela SEC para dar ao público a sensação de que algo estava sendo feito para punir os especuladores e gananciosos de Wall Street que supostamente contribuíram para a crise. $\mathrm{O}$ apelo popular que uma proibição como esta gerava permitiu à SEC expandir sua área de atuação e garantiu à agência mais uma fonte de receitas e prestígio. Outros participantes do mercado, tais como bancos de investimento e integrantes do sistema de distribuição deram apoio ao lobby de proibição ao uso de informações privilegiadas, muito provavelmente porque estes players seriam os próximos da fila no acesso a informações relevantes e sigilosas.

Seguindo o exemplo norte-americano, diversos países do mundo e, dentre eles, o Brasil, passaram a editar leis - em alguns casos, quase cópias da legislação dos Estados Unidos - proibindo o insider trading, sem demonstrar grande preocupação em entender as reais razões por trás da proibição e suas consequências para o mercado.

Como visto, a legislação brasileira de combate ao insider trading, assim como a legislação dos principais países com mercados de capitais desenvolvidos, foi se tornando cada vez mais ampla e rígida ao longo tempo. Atualmente, o combate à negociação com base em informações privilegiadas mostra-se presente não só na Lei $n^{\circ}$ 6.404/76 e na regulamentação da CVM, como consta expressamente do rol de objetivos e princípios da regulação do mercado de capitais brasileiro previsto na Lei ${ }^{\circ} 6.385 / 76$.

Estes objetivos e princípios buscam promover a máxima do full and fair disclosure, de forma que o mercado de capitais e seus participantes atuem sempre sob os ditames da eficiência, transparência e da maior quantidade de 
informações possível. Não obstante o mérito e a eficiência do princípio do full and fair disclosure serem, no mínimo, questionáveis, fato é que, por uma série de razões, a igualdade de acesso a informações no mercado de capitais é um ideal que beira o impossível, sendo a assimetria informacional, portanto, a regra deste mercado.

Acreditando que poderiam atenuar os efeitos da assimetria informacional, o legislador e o regulador brasileiros e da maioria dos países com mercados de capitais desenvolvidos passaram a editar uma série de normas visando proibir que aqueles que têm acesso a informações relevantes e sigilosas pudessem delas se aproveitar antes que as mesmas fossem divulgadas ao mercado. Entretanto, as dificuldades de interpretação e aplicação das normas de combate ao insider trading não tardaram a aparecer e continuam presentes até os dias de hoje. Questões como a prova de acesso, transmissão e uso da informação privilegiada, legitimidade passiva para figurar em uma ação de reparação de danos pelo uso de informações privilegiadas e a natureza do tipo penal do insider trading fazem com que a proibição da prática nas esferas administrativa, civil e penal torne-se, no mínimo, problemática.

Prova dessa dificuldade pode ser observada ao se analisar os números de condenações e absolvições no âmbito dos processos administrativos sancionadores instaurados pela CVM. Desde a criação da autarquia, o número consideravelmente maior de absolvições face às condenações em casos de insider trading pode passar ao mercado a impressão de que a relação custo/benefício na utilização de informações privilegiadas compensa o relativamente baixo risco de ser pego. Por outro lado, os recursos financeiros, técnicos e humanos utilizados pela CVM para travar esta guerra aparentemente perdida poderiam ser concentrados em outras questões igualmente ou mais importantes que a negociação com base em informações privilegiadas. 
Apesar de todos estes problemas, a discussão sobre a real necessidade das normas de combate à utilização de informações privilegiadas nunca recebeu a devida atenção da doutrina brasileira.

Não restam dúvidas de que um mercado de capitais eficiente é vital para o desenvolvimento econômico de qualquer país. Um mercado eficiente tende a promover a alocação eficaz da poupança no setor produtivo, contribuindo, consequentemente, para o crescimento econômico. No entanto, para que o mercado de capitais se desenvolva, faz-se necessário buscar a conciliação de interesses daqueles dispostos a aplicar seus recursos no mercado com as empresas que buscam obter financiamento por esta via. Caso contrário, haverá um desequilíbrio, seja pelo número reduzido de companhias abertas, seja pelo receio dos investidores em aplicar suas poupanças no mercado.

É justamente neste contexto que se mostra necessário repensar sobre as diversas consequências que a proibição do insider trading pode trazer. Como visto, os argumentos utilizados para proibir o insider trading possuem falhas graves que os tornam frágeis demais para sustentar a presença de normas e proibições da forma como elas existem hoje no Brasil. Mas não é só. A busca pela eficiência do mercado de capitais tende a ser prejudicada pelas normas de combate ao insider trading, agravando, dentre outros, o problema da assimetria informacional.

Neste ponto, julga-se relevante trazer uma das distinções mais essenciais feitas no direito anglo-americano, que divide os atos entre atos malum in se e atos malum prohibitum. De acordo com a definição do Black's Law Dictionary, um ato malum in se é aquele ato considerado errado em si mesmo ("evil in itself"), ou seja, um ato "that is inherently imoral, such as 
murder, arson, or rape". ${ }^{350}$ Já os atos malum prohibitum são aqueles atos considerados errados somente por serem proibidos por lei ou outros tipos de normas ("wrong due to being prohibited"), ainda que o ato em si não seja necessariamente imoral ${ }^{351}$. Curiosamente, o dicionário disponível no site www.law.com traz como primeiro exemplo de atos malum prohibitum as violações ao Securities and Exchange Act e às leis que preveem os crimes de colarinho branco, e, mais especificamente, o uso de informações privilegiadas.

Coincidência ou não, fato é que a definição do insider trading como um ato malum prohibitum parece se encaixar perfeitamente no contexto que envolve a proibição de tal prática. Como visto, a percepção de que o insider trading é algo essencialmente ruim para o mercado passou a ser encarada como uma verdade absoluta, que durante muito tempo permaneceu intacta.

No entanto, apesar do longo e ativo debate, a proibição do insider trading continua sendo, nas palavras de BAINBRIDGE ${ }^{352}$, um enigma jurídico e econômico. Não há nenhuma teoria completamente satisfatória que explique a proibição da forma como ela existe nos principais países do mundo, e a falta de justificativas satisfatórias para a proibição é particularmente perturbadora em vista das gravíssimas sanções existentes e da baixa probabilidade de punição.

Com efeito, CARLTON e FISCHEL observam que a conveniência da existência ou não de normas proibindo o insider trading é, em última análise, uma questão empírica. ${ }^{353}$ No entanto, ressalvam os autores, "to show that

\footnotetext{
${ }^{350}$ GARNER, Bryan A. (editor chefe). Black's Law Dictionary. $9^{\text {a }}$ edição. Estados Unidos: West Publishing Co., 2009. p. 1045.

${ }^{351}$ Ibid. p. 1046.

352 BAINBRIDGE, Stephen M. The Insider Trading Prohibition: A Legal and Economic Enigma. Florida Law Review, Vol. 38, 1986. pp. 33-34. Disponível em SSRN: http://ssrn.com/abstract=303880.

${ }^{353}$ CARLTON, Dennis. W. e FISCHEL, Daniel.R. The Regulation of Insider Trading. Stanford Law Review, 1983. p. 866.
} 
insider trading would not be optimal in a world of perfect information is not a compelling argument for prohibiting insider trading in a world of costly monitoring and imperfect information". 354

Deste modo, observa $\mathrm{MCGEE}^{355}$, melhor seria se, no longo prazo, estudos fossem realizados visando isolar aqueles indivíduos ou grupos efetivamente prejudicados pelo insider trading - se é que tais indivíduos ou grupos de fato existem - para, então, editar uma norma específica que (i) proíba a prática do insider trading contra estas pessoas; e (ii) ao mesmo tempo, permita que os outros tipos de insider trading possam ser praticados sem o risco de punição. No entanto, até que se possa constatar de forma clara que alguém é efetivamente prejudicado pela prática do insider trading, não deveria existir leis ou normas impedindo a utilização de informações privilegiadas.

Assim, os órgãos reguladores - notadamente a CVM - deveriam repensar a sua política de repressão ao insider trading para não mais punir os investidores que buscam negociar com as informações mais precisas e recentes sobre as companhias. Afinal, lembra BANDOW, "that's what the financial markets should be about" ${ }^{\text {356. }}$.

\footnotetext{
${ }^{354}$ Ibid. p. 873.

${ }^{355}$ MCGEE, Robert W. Ethical Issues in Insider Trading: Case Studies. pp. 21-22. Disponível em SSRN: http://ssrn.com/abstract=538682.

356 BANDOW, Doug. It's time to legalize insider trading. Disponível em http://www.forbes.com/2011/01/20/legalize-insider-trading-economics-opinions-contributors-dougbandow.html. p. 3 .
} 


\section{BIBLIOGRAFIA}

AKERLOF, George A. The Market for 'Lemons': Quality Uncertainty and the Market Mechanism. The Quarterly Journal of Economics, Vol. 84, No. 3. MIT Press: 1970. 12 p.

AKTAS, Nihat; DE BODT, Eric e VAN OPPENS, Hervé, Evidence of the Contribution of Legal Insider Trading to Market Efficiency. 40 p. Disponível em http://ssrn.com/abstract=871766. Acessado em 03.10.2012.

ALMEIDA, Luiz Carlos Barnabé de. Introdução ao Direito Econômico. 4. ed. São Paulo: Saraiva, 2012. 333 p.

ALVARENGA, Maria Isabela de Almeida. Adequação das funções legais da Comissão de Valores Mobiliários a realidade brasileira. Revista de Direito Mercantil, Industrial, Econômico e Financeiro. São Paulo: $\mathrm{n}^{\circ}$ 105, ano XXXVI, jan.-mar. 1997. p $144-158$.

AMENDOLARA, Leslie. Fundamentos e Objetivos da Regulamentação do Sistema de Informação de Sociedades que fazem Ofertas Públicas. In: VII Congreso Argentino de Derecho Societario y III Congresso Iberoamericano de Derecho Societario y de la Empresa. La Sociedad Comercial ante El tercer milênio. Buenos Aires, 40 p.

ANDERSON, Benjamin M. Economics and the Public Welfare: A Financial and Economic History of the United States. $2^{\mathrm{a}}$ Edição. Indianapolis: Liberty Press, 1979. 595 p.

ANDREZO, Andrea Fernandes. A necessidade de maior transparência das informações e orientação dos investidores para o desenvolvimento do mercado de valores mobiliários. Revista da CVM, n. 30, dez. 1999. 8 p. 
APRIGLIANO, Ricardo de Carvalho. Insider Trading. Comentário de Ricardo de Carvalho Aprigiliano ao acórdão do Tribunal de Justiça de São Paulo na Apelação Cível n. 12.145-1. Revista de Direito Mercantil, Industrial, Econômico e Financeiro. São Paulo: ${ }^{\circ}$ 109, ano XXXVI, jan.-mar. 1998. p $173-189$.

ARAGÃO, Alexandre Santos de. O conceito jurídico de regulação da economia. Revista de Direito Mercantil, Industrial, Econômico e Financeiro. São Paulo: n 122, ano XL, abr.-jun. 2001. p 38 - 48.

ASHE, Michael e RIDER, Barry. Insider Crime - The New Law. Jordans: United Kingdom, 1993. 129 p.

BAINBRIDGE, Stephen M. Insider Trading: An Overview. 41 p. Disponível em http://ssrn.com/abstract=132529. Acessado em 03.10.2012.

BAINBRIDGE, Stephen M. The Insider Trading Prohibition: A Legal and Economic Enigma. Florida Law Review, Vol. 38, 1986. 36 p. Disponível em SSRN: http://ssrn.com/abstract=303880. Acessado em 03.10.2012.

BAINBRIDGE, Stephen M. The Law and Economics of Insider Trading: A Comprehensive Primer. 84 p. Disponível em http://ssrn.com/abstract=261277. Acessado em 03.10.2012.

BANDOW, Doug. It's time to legalize insider trading. Disponível em http://www.forbes.com/2011/01/20/legalize-insider-trading-economicsopinions-contributors-doug-bandow.html. Acessado em 03.10.2012.

BANDOW, Doug. What's Wrong About Insider Trading? Disponível em: http://www.cato.org/publications/commentary/whats-wrong-about-insidertrading. Acessado em 03.10.2012. 
BERLE, Adolf Augustus. MEANS, Gardiner Coit. The modern corporation and private property. New Brunswick: Transaction Publishers, 2009. 380 p.

BHATTACHARYA, Uptal e DAOUK, Hazem. The World Price of Insider Trading. Journal of Finance, February 2002. 47 p.. Disponível em SSRN: http://ssrn.com/abstract=249708. Acessado em 03.10.2012.

BHATTACHARYA, Uptal e DAOUK, Hazem. When no law is better than a good law. (April 27, 2009). AFA 2008 New Orleans Meetings Paper. 64 p. Disponível em http://ssrn.com/abstract=558021. Acessado em 03.10.2012.

BITENCOURT, Cezar Roberto; e BREDA, Juliano. Crimes contra o Sistema Financeiro Nacional \& contra o Mercado de Capitais. Rio de Janeiro: Lumen Juris, 2010. 404 p.

BLACK, Bernard S. Strengthening Brazil's Securities Markets. Revista de Direito Mercantil, Industrial, Econômico e Financeiro. São Paulo: ${ }^{\circ} 120$, ano XXXIX, out.-dez. 2000. p. $41-56$.

BOULOS, Eduardo Alfred Taleb; e SZTERLING, Fernando. O Novo Mercado $e$ as Práticas Diferenciadas de Governança Corporativa: Exame de Legalidade Frente aos Poderes das Bolsas de Valores. Revista de Direito Mercantil, Industrial, Econômico e Financeiro. São Paulo: $n^{\circ}$ 125, ano XLI, jan.-mar. 2002. p. $96-113$.

BRANDEIS, Louis D. Other People's Money. Disponível em http://www.law.louisville.edu/library/collections/brandeis/node/191. Acessado em 03.10.2012.

BRIS, A. Do Insider Trading Laws Work? European Financial Management, $11,2005.45 \mathrm{p}$. 
BRUDNEY, Victor. Insiders, Outsiders, and Informational Advantages under the Federal Securities Laws. Harvard Law Review, Vol. 93, No. 2, (Dez., 1979). $54 \mathrm{p}$.

CARLTON, Dennis. W. e FISCHEL, Daniel.R. The Regulation of Insider Trading. Stanford Law Review, 1983. 38 p.

CARVALHOSA, Modesto e EIZIRIK, Nelson. A Nova Lei das S/A. São Paulo: Saraiva, 2002. $650 \mathrm{p}$.

CARVAlHOSA, Modesto. Comentários à Lei das Sociedades Anônimas. 4. ed. São Paulo: Saraiva, 2009. Vol. 3. 885 p.

CASS, Ronald A. One Among the Manne: Changing our Course, 50 Case W. Res. L. Rev. 203, 204 (1999).

CASTELLAR, João Carlos. Insider Trading e os Novos Crimes Corporativos. Rio de Janeiro: Ed. Lumen Juris, 2008. 141 p.

CASTRO, Hélio Oliveira Portocarrero; e EIZIRIK, Nelson Laks. Regulação e Controle do Mercado de Capitais (o papel da SEC na experiência norteamericana). Rio de Janeiro, IBMEC, 1974. 100 p.

CHEDIAK, Julian Fonseca Peña. A Reforma do Mercado de Valores Mobiliários. In: LOBO, Jorge (org.). A Reforma da lei de Sociedades Anônimas: inovações e questões controvertidas da Lei $n^{\circ} 10.303$, de 31.10.2001. Rio de Janeiro: Forense, 2002. p. 525 - 553.

COMPARATO, Fábio Konder. A regra de sigilo nas ofertas públicas de aquisição de ações. In Direito Empresarial: Estudos e Pareceres. Rio de Janeiro: Saraiva, 1990. p $331-353$. 
COMPARATO, Fábio Konder. Insider Trading: Sugestões para uma moralização do nosso mercado de capitais. Revista de Direito Mercantil, Industrial, Econômico e Financeiro. São Paulo, n 2, ano X, jan.-mar. 1971. p $41-51$.

COMPARATO, Fábio Konder. O poder de controle na sociedade anônima. $2^{\mathrm{a}}$ ed. atualizada. São Paulo: Ed. Revista dos Tribunais, 1977. 429 p.

CONSTANTINO, Rodrigo. Economia do Indivíduo: o legado da Escola Austríaca. São Paulo: Instituto Ludwig von Mises Brasil, 2009. 223 p.

COSTA, José de Faria; RAMOS, Maria Elisabete. O crime de abuso de informação privilegiada. Coimbra: Coimbra Editora, 2006. 120 p.

DEMSETZ, Harold. Perfect competition, Regulation and the Securities Market. Economic Policy and the Regulation of Corporate Securities I (H. Manne ed. 1969). 30 p.

DOLGOPOLOV, Stanislav. Insider Trading. The Concise Encyclopedia of $\begin{array}{lllll}\text { Economics. } & 8 & \text { p. } & \text { Disponível em }\end{array}$ http://www.econlib.org/library/Enc/insidertrading.html. Acessado em 03.10.2012.

DOOLEY, Michael P. Enforcement of Insider Trading Restrictions. Virginia Law Review. Vol. 66, No. 1 (Fev., 1980). p. 1 - 83

DUFFY, M. Insider Trading: Addressing the continuing problems of proof. Australian Journal of Corporate Law, 23, 2009. p. 149 - 177.

EASTERBROOK, Frank H. Insider Trading, Secret Agents, Evidentiary Privileges, and the Production of Information. The Supreme Court Review, 1981. p. $309-365$. 
EASTERBROOK, Frank H.; FISCHEL, R. Daniel. The economic structure of corporate law. Cambridge: Harvard University Press, 1996. 370 p.

EIZIRIK, Nelson Laks. A Instrução CVM 31/84 e a Regulamentação do "Insider Trading”. Revista de Direito Mercantil, Industrial, Econômico e Financeiro. São Paulo: n 55, ano XXIII, jul.-set. 1984. p. 170 - 176.

EIZIRIK, Nelson Laks. Insider Trading $e$ a Responsabilidade de Administrador de Companhia Aberta. Revista de Direito Mercantil, Industrial, Econômico e Financeiro. São Paulo: n 50, ano XXII, abr.-jun. 1983. p. 42 57.

EIZIRIK, Nelson Laks. O Liberalismo Econômico e a Criação das Disciplinas de Direito Comercial e Economia Política. Revista de Direito Mercantil, Industrial, Econômico e Financeiro. São Paulo: n 35, ano XVIII, jul.-set. 1979. p. $29-49$.

EIZIRIK, Nelson Laks. O papel do Estado na Regulação do Mercado de Capitais. Rio de Janeiro, Instituto. Brasileiro de Mercado de Capitais IBMEC, 1977. $145 \mathrm{p}$.

EIZIRIK, Nelson Laks. Questões de Direito Societário e Mercado de Capitais. Rio de Janeiro: Forense. $1^{\text {a }}$ ed. 1987. 226 p.

EIZIRIK, Nelson Laks. The Role of the State in the Regulation of the Securities Markets: the Brazilian Experience. Journal of Comparative Law and Securities Regulation 1. North-Holland Publishing Company, 1978. p. 211 - 226.

EIZIRIK, Nelson Laks; e NETTO, Horácio de Mendonça. O Privilegiamento de Informações e o Caso Petrobrás. Revista Brasileira de Mercado de Capitais, Rio de Janeiro, v. 4, n. 10, jan./abr. 1978. 
EIZIRIK, Nelson Laks; GAAL, Ariádna B.; PARENTE, Flávia; HENRIQUES, Marcus de Freitas. Mercado de Capitais - regime jurídico. 2. ed. (revisada e atualizada). Rio de Janeiro: Renovar, 2008. 660 p.

EIZIRIK. Nelson Laks. Regulação e auto-regulação do mercado de valores mobiliários. Revista de Direito Mercantil, Industrial, Econômico e Financeiro. São Paulo: n 48, ano XXI, out.-dez. 1982. p. 49 - 60.

FAMA, Eugene F. Efficient Capital Markets: A Review of Theory and Empirical Work. The Journal of Finance, v. 25, n. 2, 1970. p. $383-417$.

FILHO, Alfredo Lamy. A Reforma da Lei das Sociedades Anônimas. Revista de Direito Mercantil, Industrial, Econômico e Financeiro. São Paulo: ${ }^{\circ} 7$, ano XI, 1972. p. $123-161$.

FILHO, Alfredo Lamy; PEDREIRA, José Luiz Bulhões. A Lei das S.A. $3^{\mathrm{a}}$ ed. Rio de Janeiro: Renovar, 1997. Vol. 1. 508 p.

FILHO, Alfredo Lamy; PEDREIRA, José Luiz Bulhões. Direito das Companhias. Vol. 1. Rio de Janeiro: Forense, 2009. 1128 p.

FONSECA, Herculano Borges. O Papel da Comissão de Valores Mobiliários na Economia Brasileira. Revista da CVM, v. 1, n. 1, jan./abr. 1983.

FOX, Merrit B. Securities Disclosure in a Globalizing Market: Who Should Regulate Whom? Michigan Law Review, v. 95, n. 8, Aug., 1997, p. 2501 2628.

FRIEDMAN, Milton. Capitalismo e Liberdade. São Paulo: Editora Abril, 1984. $187 \mathrm{p}$. 
FRIJNS, Bart; GILBERT, Aaron B.; e TOURANI-RAD, Alireza. Do Criminal Sanctions Deter Insider Trading? (March 14, 2011). 37 p. Disponível em SSRN: http://ssrn.com/abstract=1785873. Acessado em 03.10.2012.

GARNER, Bryan A. (editor chefe). Black's Law Dictionary. $9^{a}$ edição. Estados Unidos: West Publishing Co., 2009. 1920 p.

GARRIGUES, Joaquim. Problemas Atuais das Sociedades Anônimas. Tradução, prefácio e notas do Prof. Noberto da Costa Caruso McDonald. Porto Alegre: Fabris, 1982. 71 p.

GILLEN, Mark. The Role of Securities Regulation in Promoting a Competitive Capital Market. Victoria: Task Force to Modernize Securities Legislation in Canada, 2006. 96 p. Disponível em http://www.tfmsl.ca/docs/V4(1)\%20Gillen.pdf. Acessado em 03.10.2012.

GILSON, Ronald J. e KRAAKMAN, Reinier H. The Mechanisms of Market Efficiency. Virginia Law Review. Vol. 70, No. 4, Fifty Years of Federal Securities Regulation: Symposium on Contemporary Problems in Securities Regulation: 1984. p. $549-644$.

GRAU, Eros. A ordem econômica na constituição de 1988. 3. ed. São Paulo: Malheiros, 1997. 384 p.

GUERREIRO, José Alexandre Tavares. Sobre o poder disciplinar da CVM. Revista de Direito Mercantil, Industrial, Econômico e Financeiro. São Paulo: $n^{\circ} 43$, ano XX, 1981. p $64-79$.

HADDOCK, David D. Academic Hostility and SEC Acquiescence: Henry Manne's Insider Trading. 50 Case W. Res. L. Rev. 313 1999-2000. 
HADDOCK, David D. e MACEY, Jonathan R. Regulation on Demand: A Private Interest Model, with an Application to Insider Trading Regulation. 30 Journal of Law and Economics, 1987. p. 311 - 352.

HAFT, Robert J. The Effect of Insider Trading Rules on the Internal Efficiency of the Large Corporation. Michigan Law Review, Vol. 80, No. 5 (Abr., 1982), p. $1051-1071$.

HUGON, Paul. História das doutrinas econômicas. São Paulo: Atlas, 1995. $431 \mathrm{p}$.

IOSCO (2003). Insider Trading - How Jurisdictions Regulate It. Disponível em www.iosco.org. Acessado em 03.10.2012.

IOSCO (2008). Objectives and Principles of Securities Regulation. p. 12. Disponível em www.iosco.org. Acessado em 03.10.2012.

IOSCO (2010). Objectives and Principles of Securities Regulation. p. 12. Disponível em www.iosco.org. Acessado em 03.10.2012.

IRTI, Natalino. L'Ordine Giuridico del Mercato. Bari: Editori Laterza, 2003. $180 \mathrm{p}$.

JENSEN, Michael C. Agency Costs of Overvalued Equity. 34 FIN.MGMT. 5, 2005. 18 p.

JR., William A. Kelly; NARDINELLI, Clark; e WALLACE, Myles S. Regulation Of Insider Trading: Rethinking SEC Policy Rules. Massachusetts: Cato Journal (Vol.7, n²), 1987. p. $441-448$.

JÚNIOR, José Cretella. Prática do Processo Administrativo. São Paulo: Revista dos Tribunais, 1989. $217 \mathrm{p}$. 
KINGSBURY, B.; KRISCH, N.; e STEWART, R. B. The emergence of Global Administrative Law. p. 15 - 61. Disponível em http://ssrn.com/abstract=692628. Acessado em 03.10.2012.

KÜMPEL, Siegfried. Direito do Mercado de Capitais - do ponto de vista do direito europeu, alemão e brasileiro - introdução. Rio de Janeiro: Renovar, 2007. $311 \mathrm{p}$.

LAMBERT, Thomas A.. A Middle Ground Position in the Insider Trading Debate: Deregulate the Sell Side (October 1, 2007). University of MissouriColumbia School of Law. Legal Studies Research Paper No. 2007-18. 23 p. Disponível em http://ssrn.com/abstract=1018758. Acessado em 03.10.2012.

LEÃES, Luiz Gastão Paes de Barros. Mercado de Capitais \& "Insider Trading”. $1^{a}$ ed. São Paulo: Ed. Revista dos Tribunais, 1978. 202 p.

LIN, Ji-Chai e ROZEFF, Michael S. The Speed of Adjustment of Prices to Private Information: Empirical Tests, 18 J. FIN. RES. 143 (1995). 14 p.

LOSS, Louis. O Papel do Governo na Proteção dos Investidores. Revista de Direito Mercantil, Industrial, Econômico e Financeiro. São Paulo, ${ }^{\circ} 58$, ano XXIV, abr.-jun. 1985. p $71-89$.

LUCENA, José Waldecy. Das Sociedades Anônimas - comentários à lei (arts. 121 a 188). Vol. 2. Rio de Janeiro: Renovar, 2009. 1067 p.

MANNE, Henry G. Insider trading and property rights in new information. Cato Journal, Vol. 4, No. 3, 1985. p. 933 - 957.

MANNE, Henry G. Insider Trading and the Law Professors. 23 Vand. L. Rev. 547 (1969-1970). p. $547-590$. 
MANNE, Henry G., Insider Trading and the Stock Market. New York: Free Press, 1966. 274 p.

MCGEE, Robert W. Ethical Issues in Insider Trading: Case Studies. 28 p. Disponível em SSRN: http://ssrn.com/abstract=538682. Acessado em 03.10.2012.

MCLEAN, Bethany e ELKIND, Peter. The Smartest Guys in the Room: The Amazing Rise and Scandalous Fall of Enron. Penguin Group, 2003. 440 p.

MELLO, Celso Antônio Bandeira. O Estado e a Ordem Econômica. Revista de Direito Público RDP 62/34 abr.-jun./1982. p. 37 - 50.

MEULBROEK, Lisa K. An Empirical Analysis of Illegal Insider Trading, 47 J. FIN. 1661 (1992). p. $1661-1699$.

MISES, Ludwig von. Ação Humana: um Tratado de Economia, trad. de Donald Stewart Jr., Rio de Janeiro: Instituto Liberal, 1990. 1002 p.

MISES, Ludwig Von. Intervencionismo - Uma análise econômica. São Paulo: Instituto Ludwig von Mises Brasil, 2010. 160 p.

MORGAN, R. J. Insider Trading and the Infringement of Property Rights. Ohio State Law Journal, 1987, 48, p. 79-116.

MOSQUERA, Roberto Quiroga. Os Princípios Informadores do Direito do Mercado Financeiro e de Capitais. In: MOSQUERA, Roberto Quiroga (org.). Aspectos Atuais do Direito do Mercado Financeiro e de Capitais. São Paulo: Dialética, 1999.

MUNDHEIM, Robert H. Tendências do Processo de Disclosure nos Estados Unidos. Revista Brasileira de Mercado de Capitais, Rio de Janeiro, v. 1, n. 2 , mai./ago. 1975. 
MUSSNICH, Francisco Antunes Maciel. A utilização desleal de informações privilegiadas - "insider trading" - no Brasil e nos Estados Unidos. Revista de Direito Mercantil, Industrial, Econômico e Financeiro. São Paulo: $n^{\circ} 34$, ano XVIII, abr.-jun. 1979. p. $31-53$.

NASCIMENTO, João Pedro Barroso do. Medidas Defensivas à Tomada de Controle de Companhias. São Paulo: Quartier Latin, 2011. 285 p.

PACHECO, Pedro Mercado. El Análisis Económico del Derecho- una reconstrucción teórica. Madrid: Cento de Estudios Constitucionales, 1994.

PARENTE, Norma Jonssen. A Regulação e o Desenvolvimento do Mercado de Capitais. Revista de Direito Bancário, do Mercado de Capitais e da Arbitragem. São Paulo: ${ }^{\circ}$ 18, ano 5, out.-dez. 2002. p. 247 - 249.

PARENTE, Norma. Aspectos Jurídicos do "Insider Trading". CVM. Superintendência Jurídica, Junho de 1978. 27 p.

PRITCHARD, Adam. C. Self-Regulation and Securities Market. 7 p. Disponível em http://ssrn.com/abstract=318939. Acessado em 03.10.2012.

PROENÇA, José Marcelo Martins. Insider Trading. Regime jurídico do uso de informações privilegiadas no mercado de capitais. São Paulo: Ed. Quartier Latin, 2005. p. 352 p.

PROENÇA, José Marcelo Martins. O que falta à criminalização do insider trader no Brasil. Disponível em http://www.bovespa.com.br/Investidor/Juridico/051206NotA.asp. Acessado em 03.10.2012.

RAO, P.K.. The Economics of Transaction Costs: Theory, Methods and Applications. Grã-Bretanha, Antony Rowe, 2003. 224 p. 
REED, Lawrence W. Great Myths of the Great Depression. Foundation for Economic Education, 2011. Disponível em http://c457332.r32.cf2.rackcdn.com/wpcontent/uploads/2011/06/GreatMyths2011FINALweb.pdf . Acessado em 03.10.2012.

REIS, Célia; SANTOS, Felipe. Divulgação de Informação. Cadernos do Mercado de Valores Mobiliários, n²8, dez/2007, CMVM, Lisboa.

RODRIGUES, Sofia Nascimento. Proteção dos Investidores em Valores Mobiliários. Coimbra: Almedina, 2001.

ROMANO, Roberta. Empowering Investors: A Market Approach to Securities Regulation (1998). Faculty Scholarship Series. Paper 1914. p. 2365 - 2430.

SANTOS, Alexandre Pinheiro dos; OSÓRIO, Fabio Medina; e WELLISCH, Julya Sotto Mayor. Mercado de Capitais - Regime Sancionador. São Paulo: Saraiva, 2012. 295 p.

SCALZILLI, João Pedro; SPINELLI, Luis Felipe. A Racionalidade Econômica do Combate ao Insider Trading: Assimetria de Informação e Dano ao Mercado. Revista de Direito Mercantil, Industrial, Econômico e Financeiro. São Paulo: ${ }^{\circ}$ 147, ano XLVI, jul.-set. 2007. p. $42-55$.

SCHAPIRO, Mary L. Building a Stable and Efficient Financial System. Disponível em http://www.sec.gov/news/speech/2009/spch050809mls.htm. Acessado em 03.10.2012.

SCHOTlAnd, Roy A. Unsafe at Any Price: A Reply to Manne, Insider Trading and the Stock Market. Virginia Law Review. Vol. 53, No. 7 (Nov., 1967).p. $1447-1448$. 
SHAVELL, Steven. Risk Sharing and Incentives in the Principal and Agent Relationship. The Bell Journal of Economics. Vol. 10, No. 1, 1979. p. 55 - 73.

SHEN, Han. A comparative study of insider trading regulation enforcement in the U.S. and China. Journal of Business \& Securities Law, Vol. 9, No. 1, Fall 2008. 34 p. Disponível em SSRN: http://ssrn.com/abstract=964548. Acessado em 03.10.2012.

SHENG, Andrew. Disclosure Regulation: The Role of Intermediaries. Asia Pacific In-House Counsel Summit, 2004.

SOUZA, Felipe Drumond Coutinho de. A criminalização do insider trading no direito brasileiro. 110 p. Monografia (Graduação em Direito) - Pontifícia Universidade Católica do Rio de Janeiro: Rio de Janeiro, 2010. 110 p.

STEWART, James B. In a New Era of Insider Trading, It's Risk vs. Reward Squared. The New York Times. 7 dez. 2012. Disponível em http://www.nytimes.com/2012/12/08/business/insider-trading-persists-andgets-stealthier.html?pagewanted=all\&_r=0. Acessado em 03.10.2012.

SZTAJN, Rachel. Conceito de liquidez na disciplina do mercado de valores mobiliários. Revista de Direito Mercantil, Industrial, Econômico e Financeiro. São Paulo: ${ }^{\circ}$ 126, ano XLI, abr.-jun. 2002. p. 7 - 31.

SZTAJN, Rachel. Law and Economics. Revista de Direito Mercantil, Industrial, Econômico e Financeiro. São Paulo: n 137, ano XLIV, jan.-mar. 2005. p. $227-233$.

SZTAJN, Rachel. Regulação e o Mercado de Valores Mobiliários. Revista de Direito Mercantil, Industrial, Econômico e Financeiro. São Paulo: ${ }^{\circ} 135$, ano XLIII, jul.-set. 2004. p. $136-148$. 
TIMBÓ, Ivo Cordeiro Pinho. Regime Jurídico da Informação no Mercado de Capitais. Dissertação de Mestrado (Pós Graduação Stricto Sensu em Direito Político e Econômico) - Universidade Presbiteriana Mackenzie, São Paulo, 2006. 223 p.

TRINDADE, Marcelo F. O Papel da CVM e o Mercado de Capitais. In: JAIRO SADDI (org.). Fusões e Aquisições: Aspectos Jurídicos e Econômicos. São Paulo: IOB, 2002.

TRINDADE, Marcelo Fernandez. Vedações à Negociação de Valores Mobiliários por Norma Regulamentar: Interpretação e Legalidade. Temas de Direito Societário Empresarial Contemporâneos. São Paulo: Malheiros, 2011. p. $453-472$.

TRINDADE, Marcelo. A Revisão da Estrutura de Supervisão do Mercado de Capitais no Brasil. Rio de Janeiro: Grupo de Trabalho de Estudos Regulatórios, ANBIMA.

WAGNER, Robert E. Gordon Gekko to the rescue?: insider trading as a tool to combat accounting fraud. University of Cincinnati Law Review: Vol. 79: Iss. $\quad 3, \quad$ Article 2, 2011. Disponível em http://scholarship.law.uc.edu/uclr/vol79/iss3/2. Acessado em 03.10.2012.

WELLISCH, Julya Sotto Mayor. Novo Código Penal e o Mercado de Capitais. Jornal Valor Econômico, São Paulo, p. 12, 23 jul. 2012.

WU, H.K. An Economist Looks at Section 16 of the Securities Exchange Act of 1934. Columbia Law Review, February, 1968, 68, p. 260 - 269.

YAZBEK, Otávio. Regulação do mercado financeiro e de capitais. Rio de Janeiro: Elsevier, 2009. 352 p. 
YEO, Victor CS. A Comparative Analysis of Insider Trading Regulation Who is liable and what are the sanctions? 31 p. Disponível em http://ssrn.com/abstract=260884. Acessado em 03.10.2012. 